\title{
Nanomechanics of hydrous, seismogenic crustal faults
}

Microphysical changes and phase transitions

Markus Ohl

Utrecht Studies in Earth Sciences

No. 228 


\section{Members of the dissertation committee:}

\section{Prof. dr. Hans de Bresser}

Dept. Of Earth Sciences, Utrecht University, The Netherlands

\section{Prof. dr. Virginia Toy}

Institut für Geowissenschaften, Johannes Gutenberg-Universität Mainz, Germany

\section{Prof. dr. Giulio di Toro}

Department of Geosciences, Padova University, Italy

\section{Dr. Elena Spagnuolo}

Istituto Nazionale di Geofisica e Vulcanologia, Rome, Italy

\section{Prof. dr. Holger Stünitz}

Department of Geosciences, The Arctic University of Norway, Tromsø, Norway

This research was conducted with the funding of the Dutch research organisation (NWO) under the grant number ALWOP.2015.082 with the project title: "Little grains, big impact: The nanoscale control of fault strength evolution during the seismic cycle".

\section{This research was carried out at:}

Utrecht University

Faculty of Geosciences

Department of Earth Sciences

Princetonlaan 8a, 3584 CB, Utrecht

The Netherlands

ISBN/EAN: 978-90-6266-593-8

Copyright (C) 2021 Markus Ohl

All rights reserved. No part of this publication may be reproduced in any form, by print or photo print, microfilm, or any other means, without written permission by the publishers.

Printed by: Boekdrukken.com

Author contact: m.ohl@uu.nl or markus.ohl.geo@gmail.com

Front cover: Top left: TEM-bright field image of a primary calcite nanograin with internal dislocations and amorphous carbon from Schinos, Greece, (Chapters 1 \& 2). Scale bar $200 \mathrm{~nm}$. Top right: HIM-SIMS map of ${ }^{18} \mathrm{O}$-distribution in deformed calcite fault gouge. Scale bar 500 nm. Bottom left: EEL spectra of amorphous carbon from Schinos and Arkitsa (Chapter 1). Bottom right: Representative Raman Spectrum of calcite fault gouge deformed with $\mathrm{H}_{2}{ }^{18} \mathrm{O}$ showing new bands of calcite grains with ${ }^{18} \mathrm{O}$ isotopes at $1024 \mathrm{~cm}^{-1}, 1046 \mathrm{~cm}^{-1}$ and $1068 \mathrm{~cm}^{-1}$ (Chapter 3). 


\title{
Nanomechanics of hydrous, seismogenic crustal faults \\ Microphysical changes and phase transitions
}

\author{
Nanomechanica van gehydrateerde, \\ seismogene breuken in de aardkorst \\ Microfysische veranderingen en fasetransitie \\ (met een samenvatting in het Nederlands)
}

Proefschrift

ter verkrijging van de graad van doctor aan de Universiteit Utrecht

op gezag van de

rector magnificus, prof.dr. H.R.B.M. Kummeling, ingevolge het besluit van het college voor promoties

in het openbaar te verdedigen op vrijdag 26 februari 2021

des middags te 2.30 uur

door

\section{Markus Ohl}

geboren op 5 april 1987

te Recklinghausen, Duitsland 


\section{Promotor:}

Prof. dr. M.R. Drury

\section{Copromotoren:}

Dr. O. Plümper

Dr. A.R. Niemeijer 
"A goal without a plan is just a wish"

- Antoine de Saint-Exupéry - 
$\begin{array}{lr}\text { Abstract } & 8\end{array}$

Samenvatting $\quad 12$

$\begin{array}{ll}\text { General introduction } & 17\end{array}$

$\begin{array}{ll}\text { References } & 24\end{array}$

Chapter 1: Mechanisms of fault mirror formation and fault healing in carbonate rocks

$\begin{array}{ll}\text { Abstract } & 30\end{array}$

1.1 Introduction $\quad 30$

1.2 Geological Setting $\quad 33$

1.3 Methods $\quad 34$

1.4 Results $\quad 36$

1.5 Discussion $\quad 46$

1.6 Conclusions $\quad 54$

Acknowledgements $\quad 55$

References $\quad 55$

$\begin{array}{ll}\text { Supplementary material } & 61\end{array}$

Chapter 2: Crystal-plastic deformation in seismically active carbonate fault rocks

$\begin{array}{ll}\text { Abstract } & 63\end{array}$

2.1 Introduction $\quad 63$

2.2 Geology and tectonic setting $\quad 65$

$\begin{array}{ll}2.3 \text { Methods } & 67\end{array}$

2.4 Results $\quad 69$

2.5 Discussion $\quad 76$

2.6 Conclusion $\quad 89$

Acknowledgements $\quad 90$

Supplementary material $\quad 91$

$\begin{array}{ll}\text { References } & 94\end{array}$

Chapter 3: Fluid-induced phase transformations explain weakening in crustal carbonate faults

$\begin{array}{ll}\text { Abstract } & 103\end{array}$

3.1 Introduction $\quad 104$

3.2 Methods and materials 106

3.3 Results of high-velocity experiments 111

3.4. Results of low-velocity experiments 119

3.4 Discussion 122

3.5 Conclusion $\quad 135$

References 136 
Chapter 4: Formation of a silicate fault mirror under hydrous conditions - The Dixie Valley fault

Abstract

4.1 Introduction

4.2 Geological setting

4.3 Methods

4.4. Results

4.5 Discussion

4.6 Conclusion

References

Chapter 5: Summary, discussion, and outlook

General Summary

General discussion and conclusions

Suggestions for future work

References

Appendix

Raman spectra of materials used during deformation experiments in Chapter 3

Data publication to Chapter 1:

Nanoscale structures and properties of carbonate fault mirrors revealed by scanning electron and scanning transmission electron microscope images, electron energy loss and Raman spectra

Abstract

Methods

Files

Data publication to Chapter 2:

Multi-scale electron crystal-orientation diffraction of seismically active carbonate fault rocks 


\section{Abstract}

Earthquakes can affect rocks over large scales, ranging from kilometres down to nanometres. Fault damage often localises within a narrow zone of a few millimetres, the fault core, and studies published during recent years suggest that the micro-, and nanoscale processes within these zones may even control and dictate macroscopic earthquake mechanics. Such zones of localised deformation can form ultra-polished fault surfaces, termed fault mirror surfaces, that were proposed to present nanogranular surface coatings resulting from seismic events. To address the hypothesis of nanomaterials controlling fault behaviour throughout the seismic cycle, the present research aims to provide a comprehensive investigation into processes related to deformation on the micro-, and nanoscale inside the fault core directly on, or below the principal slip surfaces. To achieve this, we conducted stateof-the-art, multi-scale electron microscopy, mass and vibrational spectroscopy, and stable-isotope geochemistry, to unravel micro-, and nanoscale deformation and transformation processes during coseismic fault gouge deformation. With the present work, we focused on three natural fault mirror surfaces and one carbonate fault-gouge deformation experiment. We also investigated the impact of mineral reactions on rock deformation under hydrous conditions.

The present work begins with a case study of two naturally formed carbonate fault mirrors from Central Greece. Micro-, and nanoscale imaging reveals piercement structures on the slip surface as indicators of decarbonation and a thin coating of amorphous carbon on the slip surface. The amorphous coating exhibits signs of hybridisation (ordering) forming a partly-hybridised amorphous carbon phase. Spatially associated with the amorphous carbon is the formation of calcite nanograins with $<50 \mathrm{~nm}$ diameter, suggesting that the amorphous carbon acted as a crystallisation medium. Electron diffraction of the calcite nanograins shows a preferred orientation related to the formation of portlandite $\left(\mathrm{Ca}(\mathrm{OH})_{2}\right)$. Hence, we hypothesise that the new calcite nanograins form by pseudomorphic replacement of portlandite by calcite on the slip surface. On the basis of the continuous coverage of amorphous carbon, we propose that calcite decarbonation products develop over the entire fault surface and may control carbonate fault mirror formation and slip.

We extended the case study of the two Greek fault mirrors in Chapter 2 and analysed the potential active deformation mechanisms by employing automated crystal-orientation mapping transmission electron microscopy and electron- 
backscatter diffraction. Based on the crystal orientation data, we performed detailed crystal-slip system analyses on the microstructure of the cataclastic fault-rock region and the nanostructure of a localised and reworked deformation zone tens of micrometres below the principal slip surface. Predictions from deformationmechanism maps indicate that the nanometric grains at the principal slip surface should deform by diffusion creep, but the crystal orientation measurements indicate the activation of the $(0001)<\overline{1} 2 \overline{1} 0>$ slip system, indicating a contribution from crystalplastic deformation. We find evidence for the same active slip system also in the cataclastic region of the fault rock despite a larger grain size of the material. Annealing and static recrystallisation after deformation produces an equilibrium micro-, and nanostructure with equant grain size and triple junctions. Based on the structural interpretations, we propose that the cyclic repetition of introducing plastic strain and post-deformational annealing poses as an alternative mechanism to grain fracturing, for producing a cohesive nanogranular material. Consequently, this mechanism leads to a grain-boundary strengthening effect which may be responsible for slip delocalisation inside a fault damage zone, producing multiple fault planes over multiple seismic cycles.

To evaluate the impact of fluids on calcite-deformation behaviour, we conducted sub-seismic $\left(v=0.1 \mu \mathrm{m} / \mathrm{s}, \sigma_{n}=50 \mathrm{MPa}, T=92{ }^{\circ} \mathrm{C}\right)$ and seismic $(v=1 \mathrm{~m} / \mathrm{s}$, $\sigma_{n}=2$ and $4 \mathrm{MPa}$ ) deformation experiments on pre-ground fault gouge. We utilised $\mathrm{H}_{2}{ }^{18} \mathrm{O}$ as pore fluid to track possible transient fluid-rock reactions during deformation. Two high-resolution secondary ion mass spectrometry techniques, as well as Raman spectroscopy, were used to observe the incorporation of ${ }^{18} \mathrm{O}$ into small grains of the gouge layer after the experiments. Formation of grains with strong ${ }^{18} \mathrm{O}$-enrichment on the time scale of 20 seconds during the high-velocity experiments suggests that isotope exchange proceeds through fluid-mediated mechanisms and not through solid-state transformation. We detected portlandite with Raman spectroscopy suggesting that calcite decarbonates to $\mathrm{CO}_{2(\mathrm{~g})}$ and $\mathrm{CaO}(\mathrm{s})$, despite the temperatures monitored during the experiments not exceeding $T_{\max }=207$ ${ }^{\circ} \mathrm{C}$. Isotope exchange commences by $\mathrm{CO}_{2}$ dissolution into the pore fluid and $\mathrm{CaO}$ hydrating to form portlandite. Amorphous carbon likely forms by reduction of $\mathrm{CO}_{2(\mathrm{~g})}$ with $\mathrm{H}_{2}(\mathrm{~g})$, where the $\mathrm{H}_{2(\mathrm{~g})}$ forms in these experiments upon electrolysis of water via a build-up of an electric potential during calcite deformation. The observation of amorphous carbon in high- and low-velocity experiments suggests that no high amount of thermal energy is needed, and that the reaction is mainly 
driven by the difference in chemical potential. We hypothesise that during the highvelocity experiments, a combination of amorphous carbon and pressurised volatiles reduces interparticle contacts, resulting in the breakdown of the load-bearing framework and leading to a fluidisation effect. Consequently, dynamic weakening from peak friction of $\mu_{p}=0.76$ to steady-state friction of $\mu_{s s}=0.16$ may result from such fluidisation. We estimate that about $65 \%$ of the former calcite fault gouge undergoes a phase transition and that seismic deformation of carbonate rocks under hydrous conditions results in the formation of secondary phases which may strongly influence and control seismic slip. The results suggest that the fault gouge deformed not as crystalline calcite but as a transient phase mixture of calcite starting material and various non-crystalline phases from reactions of pore fluid and decarbonation products and thus cannot be described with solid-state deformation mechanisms.

The thesis research on localised fault-zone deformation is completed with a case study on a natural silicate fault mirror. The Dixie Valley fault mirror in the western Basin and Range Province, Nevada, U.S.A. provides a perfect example for investigating another important mineralogical system and transferring potential conclusions from carbonate deformation to silicate deformation. We conducted high-resolution electron microscopy for detailed crystal-slip system analyses on a fine-grained and highly silicified matrix hosting the principal slip surface. Our slipsystem analysis shows that the bulk of the fine-grained top layer does not match with any known quartz-slip systems and that non-classical crystallographic preferred orientations may form by oriented attachment along the $\{10 \overline{1} \overline{1}\}$ highenergy surface of quartz. Riedel shears hosted inside the top layer exhibit the same crystallographic preferred orientation and subgrain misorientation around the $<\mathrm{m}>$ axis as the immediate region below the principal slip surface. Both crystallographic preferred orientations indicate the activation of the $\{\overline{1} 2 \overline{1} 0\}[0001]$ slip system which is commonly considered a high-temperature slip system. The common subgrain misorientation of slip surface and Riedel shears allows us to connect the Riedel shears, indicative of stable sliding, to the slip surface and infer that the crystallographic preferred orientation may also be the result of stable sliding. Geomorphological evidence of a fluid-saturated fault zone, the precipitation of amorphous carbon and related hydrothermal clay alteration leads us to the conclusion that temperature-increase on this fault was likely fluid-buffered, preventing significant frictional heating. We suggest that the combination of 
amorphous carbon and phyllosilicates along the slip surface may facilitate aseismic fault creep along the Dixie Valley fault.

The collective evidence of this thesis suggests that the physico-chemical interactions of carbonate-deformation products with fluids have a stronger impact on fault-gouge deformation and fault rheology then previously considered. Decarbonation below the excepted decarbonation temperature is the critical factor to drive co-, and post-deformational fluid-rock interactions in hydrous carbonate fault zones. Coseismic, hydrous deformation of carbonates proceeds through a fast sequence of fluid-mediated exchange reactions which leaves us with the conclusion that hydrous (natural) carbonate deformation in fault cores under upper-crustal conditions cannot be described by only solid-state deformation mechanisms. In addition to the physico-chemical interactions of decarbonation products and fluids, dislocation creep appears to contribute to cataclastic processes in fault damage zones also at lower temperatures than previously estimated for the activity range of laboratory observed slip systems. Crystal-slip system analyses suggest that fluids may influence the slip systems activated during deformation and that temperature estimates for such slip systems cannot be extrapolated from low to high strain rates without restrictions. Cyclic repetition of deformation and annealing presents an alternative mechanism to fracturing of nanostructure formation for fault rocks which ultimately appears to strengthen the material close to the principal slip surface. Finally, we propose that the syn-, and post-deformational fluid-rock interactions have a strong influence on fault slip and that such interactions with fluids are the governing factors that will control fault rheology in the systems studied here. 


\section{Samenvatting}

Aardbevingen kunnen gesteente beïnvloeden op een schaal van kilometers tot nanometers. Beschadiging door breuken is vaak gelokaliseerd in een zone van enkele millimeters, de breukkern, en recent gepubliceerde onderzoeken suggereren dat processen op micro- en nanoschaal in deze zones zelfs macroscopische aardbevings-mechanismen controleren en bepalen. Zulke zones van gelokaliseerde deformatie kunnen een ultra-gepolijst breukoppervlak vormen, zogenoemde breuk spiegels, en eerder is voorgesteld dat die bestaan uit een oppervlakkig laagje nanokorrels, gevormd door een seismisch event. Om de hypothese te testen dat nanomateriaal breukgedrag tijdens de seismische cyclus bepaalt, heeft dit onderzoek als doel om een diepgaande studie uit te voeren van deprocessen die van belang zijn voor deformatie op micro- en nanoschaal in de breukkern, op of direct onder het hoofdschuifvlak. Om dit te bereiken hebben we geavanceerde multischaal elektronenmicroscopie, massa- en vibratiespectroscopie en stabiele isotopengeochemie uitgevoerd, om deformatie- en transformatieprocessen op micro- en nanoschaal tijdens co-seismische deformatie van breukgesteente te ontrafelen. Hierbij hebben we gefocust op drie natuurlijke fault mirror-oppervlakken en één deformatie-experiment met carbonaatbreukmeel. Ook hebben we specifiek de invloed van mineraalreacties op gesteentedeformatie onder gehydrateerde omstandigheden onderzocht.

Dit onderzoek begint met een case study van twee natuurlijk gevormde carbonaat breuk spiegels in centraal Griekenland. Beelden op micro- en nanoschaal laten geperforeerde structuren zien op het schuifvlak, dit zijn indicatoren van decarbonatie en een dun laagje amorfe koolstof op het schuifvlak. Het amorfe laagje vertoont tekenen van hybridisatie (ordening) en vormt een gedeeltelijk gehybridiseerde amorfe koolstoffase. Ruimtelijk geassocieerd met de amorfe koolstof zien we de vorming van calciet nanokorrels met een diameter $<50 \mathrm{~nm}$; een aanwijzing dat de amorfe koolstof heeft gefungeerd als kristallisatiemedium. Elektronendiffractie van de calciet nanokorrels laat een kristallografische voorkeursoriëntatie zien die verband houdt met het onstaan van portlandiet $\left(\mathrm{Ca}(\mathrm{OH})_{2}\right)$. Op basis hiervan, is onze hypothese dat de nieuwe calciet nanokorrels ontstaan door pseudomorfe vervanging van portlandiet door calciet op het schuifvlak. Op basis van de continue bedekking met koolstof stellen we voor dat 
calciet decarbonatieproducten op het gehele breukoppervlak vormen en het ontstaan van breuk spiegels en verschuiving in carbonaatgesteente kunnen bepalen.

We hebben het onderzoek naar de twee Griekse breuk spiegels uitgebreid met de analyse van mogelijk actieve deformatiemechanismen met behulp van geautomatiseerde crystal orientation mapping transmissie-elektronenmicroscopie en electron-backscatter diffraction. Op basis van de kristaloriëntatiedata hebben we gedetailleerde kristal-schuifsysteemanalyses gedaan aan de microstructuur van de kataklastische zone in het breukgesteente en aan de nanostructuur van een gelokaliseerde en opnieuw bewerkte deformatiezone enkele tientallen micrometers onder het hoofdschuifvlak. Voorspellingen op basis van deformatiemechanismendiagrammen tonen aan dat de nanoschaal korrels op het schuifvlak zouden moeten deformeren door middel van diffusiekruip, maar de kristaloriëntatiemetingen wijzen op activatie van het $(0001)<\overline{1} 2 \overline{1} 0>$ schuifsysteem, wat wijst op plastische deformatie. Ook in de kataklastische zone van het breukgesteente vinden we bewijs voor hetzelfde actieve schuifsysteem, ondanks de grotere korrelgrootte van het materiaal. Ontharding en statische rekristallisatie na deformatie produceren een evenwichtsmicro- en nanostructuur met equidimensionale korrels en driesprongen. Op basis van de structurele interpretaties stellen we voor dat de cyclische herhaling van het introduceren van plastische vervorming en post-deformatie ontharding een op korrelbreuk alternatief mechanisme vormt, op korrelbreuk, om een samenhangend nanokorrelig materiaal te produceren. Vervolgens leidt dit mechanisme tot een korrelgrensversterkend effect, dat verantwoordelijk zou kunnen zijn voor delokalisatie van verschuiving in een breukbeschadigingszone, waardoor meerdere breukvlakken gevormd kunnen worden tijdens de seismische cyclus.

Om het effect van vloeistoffen op het deformatiegedrag van calciet te onderzoeken, hebben we sub-seismische $\left(v=0.1 \mu \mathrm{m} / \mathrm{s}, \sigma_{n}=50 \mathrm{MPa}, T=92^{\circ} \mathrm{C}\right)$ en seismische $\left(v=1 \mathrm{~m} / \mathrm{s}, \sigma_{n}=2\right.$ and $\left.4 \mathrm{MPa}\right)$ deformatieexperimenten uitgevoerd op voorgemalen breukmeel. We hebben $\mathrm{H}_{2}{ }^{18} \mathrm{O}$ gebruikt als poriënvloeistof om mogelijke overgangsreacties tussen vloeistof en gesteente tijdens de deformatie te volgen. Twee hoge resolutie secundaire ionen-massaspectrometrietechnieken en Raman spectroscopie werden gebruikt om na afloop van de experimenten de incorporatie van ${ }^{18} \mathrm{O}$ in kleine korrels te observeren. Het ontstaan van korrels met een sterke ${ }^{18} \mathrm{O}$-verrijking op een tijdschaal van twintig seconden tijdens de hoge snelheidsexperimenten suggereert dat isotopenuitwisseling plaatsvindt via 
vloeistof-geassisteerde processen en niet via vaste toestandtransformatie. 1We detecteren portlandiet met Raman spectroscopie, wat een aanwijzing is dat calciet decarboniseert naar $\mathrm{CO}_{2(\mathrm{~g})}$ en $\mathrm{CaO}_{(\mathrm{s})}$, ondanks het feit dat de temperatuur gemeten tijdens het experiment niet hoger dan $T_{\max }=207^{\circ} \mathrm{C}$ werd. Isotopenuitwisseling begint met $\mathrm{CO}_{2}$-oplossing in de poriënvloeistof en $\mathrm{CaO}$-hydratatie, waarbij portlandiet gevormd wordt. Amorfe koolstof vormt waarschijnlijk door reductie van $\mathrm{CO}_{2(\mathrm{~g})}$ met

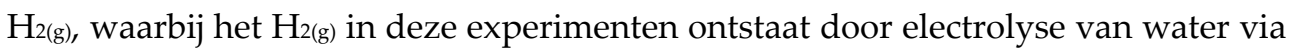
de opbouw van een elektrisch potentiaal tijdens calcietdeformatie. De observatie van amorfe koolstof in hoge en lage snelheidsexperimenten suggereert dat er geen grote hoeveelheid thermische energie nodig is en dat de reactie voornamelijk wordt gedreven door het chemisch potentiaalverschil. We stellen de hypothese voor dat tijdens de hoge snelheids-experimenten een combinatie van amorfe koolstof en vluchtige stoffen onder druk het contact tussen korrels vermindert, wat resulteert in de afbraak van het lastdragende raamwerk en leidt tot een fluïdisatie-effect. Als gevolg van dit fluïdisatie-effect kan dynamische verzwakking optreden van een piekfrictie van $\mu_{p}=0.76$ naar een evenwichtsfrictie van $\mu_{s s}=0.16$. We schatten dat ongeveer $65 \%$ van het voormalige calcietbreukmeel een fasetransformatie ondergaat en dat seismische deformatie van carbonaatgesteente onder gehydrateerde omstandigheden resulteert in het ontstaan van nieuwe fases die seismische verschuiving sterk beïnvloeden en bepalen. De resultaten suggereren dat het breukmeel niet deformeerde als kristallijne calciet, maar als een overgangsfasemix van calciet startmateriaal en verschillende niet-kristallijne fases afkomstig van reacties tussen poriënvloeistof en decarbonisatieproducten, en dus niet beschreven kan worden met vaste stof-deformatiemechanismen.

We ronden het onderzoek naar gelokaliseerde breukzonedeformatie af met een case study aan een natuurlijke silicaat breuk spiegels. De Dixie Valley breuk spiegel in de westelijke Basin and Range Province, Nevada, V.S. biedt een perfect voorbeeld om een ander belangrijk mineraalsysteem te bestuderen en mogelijke conclusies op basis van carbonaatdeformatie hiernaar over te brengen. We voerden hoge resolutieelektronenmicroscopie uit om gedetailleerde kristalschuifsysteemanalyses uit te voeren op een fijnkorrelige en sterk gesilicificeerde bovenlaag met daarin het hoofdschuifvlak. De resultaten van de schuifsysteemanalyse laten zien dat het gedrag in de bulk van de fijnkorrelige toplaag niet overeenkomt met een slipsysteem in kwarts, en dat niet-klassieke kristallografische voorkeursoriëntaties kunnen ontstaan door georiënteerde aanhechting op het hoog-energetische $\{10 \overline{1} \overline{1}\}$ 
kristalvlak van kwarts. Riedel schuifvlakken in de toplaag laten dezelfde kristallografische voorkeursoriëntatie en subkorrelmisoriëntatie rond de $<\mathrm{m}>$-as zien als het gebied direct onder het hoofd-schuifvlak. Beide kristallografische voorkeursoriëntaties zijn een aanwijzing voor de activatie van het $\{\overline{1} 2 \overline{1} 0\}[0001]$ schuifsysteem, dat algemeen beschouwd wordt als een hoge temperatuur schuifsysteem. Door de gemeenschappelijke subkorrelmisoriëntatie van hoofdschuifvlak en Riedelschuifvlakken kunnen we de Riedelschuifvlakken, die indicatief zijn voor stabiel schuiven, verbinden met het hoofdschuifvlak en kunnen we hieruit opmaken dat de kristallografische voorkeursoriëntatie ook het resultaat is van stabiel schuiven. Geomorfologisch bewijs voor een breukzone verzadigd met vloeistof, de precipitatie van amorfe koolstof en hieraan gerelateerde kleiveranderingen monden uit in de conclusie dat temperatuurverhoging op deze breuk waarschijnlijk gebufferd werd door vloeistoffen, wat temperatuurpieken voorkwam. We suggereren dat de combinatie van amorfe koolstof en phyllosilicaten op het schuifvlak a-seismische kruip op de Dixie Valley-breuk kunnen faciliteren.

Al het bewijs in dit proefschrift bij elkaar suggereert dat de fysischchemische interactie van carbonaatdeformatieproducten met vloeistoffen een sterker effect heeft op breukmeeldeformatie en breukrheologie dan tot nu toe werd aangenomen. Decarbonatie onder de verwachte decarbonatietemperatuur is de kritische factor die vloeistof-gesteente-interacties in gehydrateerde carbonaatbreukzones aandrijft tijdens en na deformatie. Co-seismische deformatie van carbonaat in aanwezigheid van water vindt plaats via een snelle opeenvolging van vloeistof-ondersteunde uitwisselingsreacties en leidt to de conclusie dat (natuurlijke) carbonaatdeformatie in aanwezigheid van water onder bovenkorstomstandigheden niet simpelweg beschreven kan worden met behulp van vaste staat-deformatiemechanismen. Naast de fysisch-chemische interacties tussen decarbonatieproducten en vloeistoffen lijkt dislocatiekruip bij te dragen aan kataklastische processen, ook onder lagere temperatuur dan tot nu toe ingeschat voor de reikwijdte van activiteit van de geobserveerde schuifsystemen. Kristalschuif-systeemanalyses duiden erop dat vloeistoffen beïnvloeden welke schuifsystemen actief zijn tijdens deformatie en dat temperatuurschattingen voor zulke schuifsystemen niet zonder restricties geëxtrapoleerd kunnen worden van lage naar hoge deformatie-snelheden. Cyclische herhaling van deformatie en ontharding vormt een alternatief mechanisme voor het ontstaan van nanostructuur in breukgesteente, wat uiteindelijk het materiaal dichtbij het hoofdschuifvlak lijkt te 
Samenvatting

versterken. Tot slot stellen we voor dat de vloeistof-gesteente-interacties tijdens en na deformatie een sterkere invloed hebben op breukverschuiving en dat interactie met vloeistoffen de bepalende factor is voor de breukreologie in de hier bestudeerde systemen.

(translated from the original by Maartje Hamers and André Niemeijer) 


\section{General introduction}

Earthquakes are among the deadliest and costliest natural disasters. Densely populated cities, for example San Francisco, Istanbul, and Tokyo, are in the immediate vicinity of active plate boundaries with the direct and indirect consequences of earthquakes and associated tsunamis affecting millions of people. The devastating impact of earthquakes on human lives is only one of many aspects that renders the investigation of the underlying physico-chemical processes operating during earthquakes an important scientific goal. The scale on which earthquakes can affect the surface and subsurface range from kilometres $\left(10^{3} \mathrm{~m}\right)$ down to the nanoscale $\left(10^{-9} \mathrm{~m}\right)$ and it is this vast range of scales, as well as the huge range in temporal scales from seconds to millions of years, that makes earthquake research complex and challenging. When deformation localises within the crust, most of the strain occurs in planar fault zones which can affect large volumes of rock (Fig. 1a). Such fault zones are the expression of discontinuous, or brittle, deformation and promote fluid flow in the crust by forming permeability structures (Caine et al., 1996). With progressing fault movement, deformation often localises within a narrow zone of only a few millimetres, the fault core (Sibson, 2003) (Fig. 1b and a). It is also suggested that nanogranular materials forming in such highly localised zones of deformation potentially control the overall macroscopic slip behaviour (Han et al., 2007a, 2007b: Han et al., 2010; Di Toro et al., 2011; Bullock et al., 2014; De Paola et al., 2015; Smeraglia et al., 2017). With the present research we will go beyond these studies and will concentrate on micro-, and nanoscale interactions of the fault gouge inside the fault core to evaluate the formation of nanogranular materials and their impact on fault mechanics. We will then go even further than only microstructural analyses and will highlight the connection of the underlying microphysical and chemical processes inside the fault gouge with fluids during seismic and subseismic deformation.

Plate-tectonic movement results in mechanical interaction at plate boundaries, leading to the accumulation of elastic strain, plate interlocking and zones of localised deformation (Fagereng and Toy, 2011). The spontaneous release of the accumulated elastic strain produces seismic events of varying magnitude, best described in the laboratory by stick-slip behaviour (Brace and Byerlee, 1966). Episodic deformation and interseismic healing will result in zones with increasing degree of deformation because earthquake slip is favoured on pre-existing zones of 
weakness (Brace and Byerlee, 1966). As a result of repeated deformation, the faultrock material decreases in grain-size from larger grains, in the wider damage zone, to extremely small grain sizes inside the fault core (Sibson, 2003) (Fig. 1a and b).
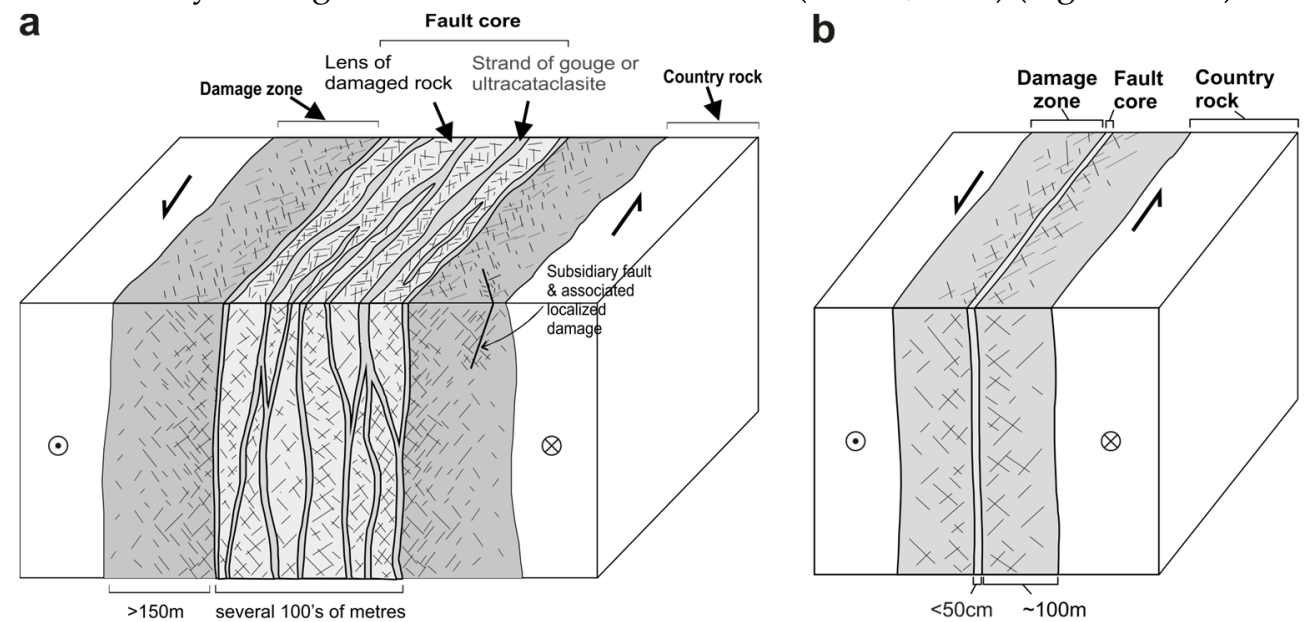

Figure 1: Conceptual fault-zone structure along the example of a strike-slip fault. $\underline{\text { : }}$ Large-scale damage zone with development of several fault cores. $\underline{\boldsymbol{b}}$ : Small-scale deformation localisation with a single fault core. Modified after (Mitchell and Faulkner, 2009).

The two main mechanisms of grain-size reduction in fault zones are brecciation and cataclasis (Sibson, 1986; Sammis et al., 1987; Blenkinsop, 1991). Often, the generic term 'comminution' is used and describes grain-size reduction in general through interparticle fracturing. The application of the term brecciation is reserved for grain-size reduction in the shallow part of the crust whereas cataclasis describes fracturing processes at greater depth (Sammis et al., 1987). Cataclasis proceeds by intragranular extension fracturing to reduce grain size and subsequent grain-shape refinement proceeds through chipping during the later stages of fault slip (Ferraro et al., 2018). Already early models by Hall (1951) and Petch (1953) predicted that fracturing of smaller grain sizes becomes increasingly difficult and requires higher stresses per grain, leading to the establishment of a grain-size limit (Sammis and Ben-Zion. 2008):

$$
d_{\min }=16\left(\frac{C K_{I C}}{2 \widehat{T}_{P}}\right)^{2}
$$

where $d_{\text {min }}$ is the minimum grain size, $C$ a geometrical constant with $C=\sqrt{2 / 3}, \widehat{T}_{p}$ is the flow stress at $0 \mathrm{~K}$ which can be approximated by $\widehat{T}_{p} \approx E / 15$, with $E$ being Youngs modulus and $K_{I C}$ being a material dependent value of toughness. For calcite, $K_{I C}=$ $0.39 \mathrm{MPa} \sqrt{m}$ and for quartz $K_{I C}=1.6 \mathrm{MPa} \sqrt{m}$ (Broz et al., 2006) and we utilise $E_{\text {calcite }}$ $=74.9 \mathrm{GPa}$ (Kunitake, 2015) and $E_{q u a r t z}=79.4 \mathrm{GPa}$ (Heyliger et al., 2003). Hence, the 
resulting theoretical grain-size limit for calcite is $d_{\text {calcite }}=16 \mathrm{~nm}$ and for quartz $d_{\text {quartz }}=$ $244 \mathrm{~nm}$. However, the size limit in Eq. (1) is regardless of temperature and strain rate. The existence of grains below this limit should, therefore, be not possible just by particle-particle fracturing because below this limit, grains tend to deform plastically rather than brittle (Sammis and Ben-Zion, 2008). Grains with such low grain sizes as mentioned above are then often termed nanograins but often grains < $1 \mu \mathrm{m}$ are already described as nanograins in the literature.

Nanograins as paleoseismicity markers are of interest especially for carbonate rocks. Because of the increasing force required to produce small particles, the discovery of nanograins in natural and experimental faults sparked the idea of nanograins being utilised as paleoseismicity markers (e.g., Siman-Tov et al. 2013). In contrast to carbonate rocks, silicate materials melt through frictional heating and form pseudotachylites, the most well-accepted signs of fossil earthquakes (Cowan, 1999). Such melting behaviour is absent for carbonates under crustal conditions and the idea of nanograins as a paleoseismicity marker appears elegant. Therefore, connecting particle-fracturing processes that require high stresses with the large amounts of energy liberated during a seismic event is intuitive. As a result of the small grain diameter, a nanograin coating on a slip surface results in a low surface roughness leading to a potential connection between mirror slip surfaces and nanograin coatings. The roughness and reflection of a surface can be described by the Rayleigh roughness criterion (Beckmann and Spizzichino, 1987):

$$
A<\frac{\lambda}{16 \cos \theta}
$$

where $A$ is the mean amplitude of the surface roughness, $\lambda$ is the wavelength the light, and $\theta$ is the angle at which the light hits the surface. Using $\lambda=550 \mathrm{~nm}$ as an average value for visible light and $\theta=0-70^{\circ}, A$ will be $<100 \mathrm{~nm}$ translating to a grain diameter of $d \sim 200 \mathrm{~nm}$. Figure 2 illustrates the geometric relationships between $A$ and $d$. It is important to note that Verberne et al. (2014) produced mirror slip surfaces under subseismic sliding conditions and demonstrated that such surfaces are not unequivocally indicative of seismic slip. A step further, nanograin coatings on top of slip surfaces were also inferred to have a lubricating effect through powder lubrication and were suggested to influence and control macroscopic fault mechanics (Han et al., 2010; Reches and Lockner, 2010). However, for a powderlubricating effect the aggregate should not be consolidated or lithified because the particles would not be able to move over and along each other. Therefore, 
considering powder lubrication in natural fault zones may not be applicable (Yao et al., 2016).

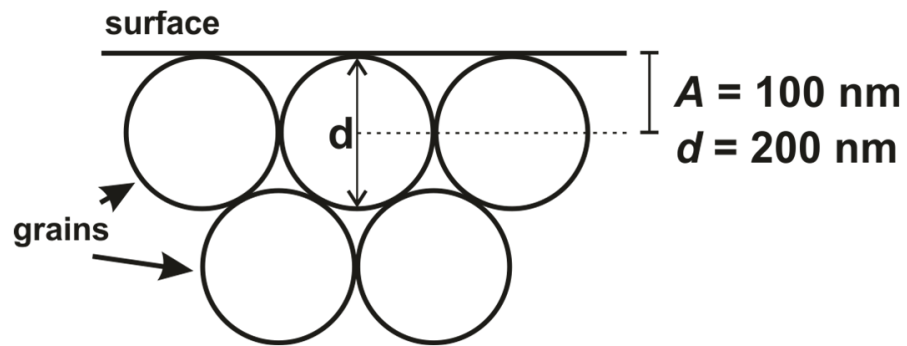

Figure 2: Sketch of nanogranular coating relating to surface roughness.

Frictional heating in carbonate rocks is an important process leading to thermal decarbonation, where $\mathrm{CaCO}_{3}$ breaks down to form $\mathrm{CO}_{2}+\mathrm{CaO}$ (lime) at temperatures $>600^{\circ} \mathrm{C}$ (Rodriguez-Navarro et al., 2009). Early studies show that $\mathrm{CO}_{2}$ emission also occurs when cleaving calcite (Dickinson et al., 1991) or milling calcite powder (Martinelli and Plescia, 2004) at macroscopic room temperatures. The formation of $\mathrm{CO}_{2}+\mathrm{CaO}$ as a result of mechanical and thermal decarbonation is a problem when considering utilising calcite nanograins as evidence of extensive fracturing. For example, the $\mathrm{CO}_{2}$ that forms from decarbonation is a separate gas phase which may immediately try to escape the deformation zone or will dissolve in the fluid that may be present. The lime formed by decarbonation may be crystalline but molecular dynamics simulations show that with a fluid present, lime will hydrate within 10 picoseconds to form portlandite $\left(\mathrm{Ca}(\mathrm{OH})_{2}\right)$ (Manzano et al., 2012). Therefore, it is unlikely that calcite or carbonate deformation will only exclusively lead to the formation of calcite nanograins which are thought to be indicative of seismic slip. In Chapter 1 and 3 of this thesis we will explore the role of decarbonation in the formation of nanogranular materials and the interaction of decarbonation products with fluids and we will discuss the resulting consequences for the rheological behaviour of carbonate-bearing faults.

The temperature-increase through frictional heating along two planar surfaces was described numerically by Rice (2006). Such a spike in temperature gives rise to other, thermally activated deformation mechanisms which would otherwise occur in deeper portions of the Earth's interior. Nielsen (2017) mentioned that the separation between brittle and ductile deformation features during the past decades may be overly strict because of frictional heating elevating temperatures to values where deformation mechanisms such as dislocation creep can operate. One of the 
main limits of thermally activated deformation mechanisms is the short duration of frictional heating. Thermal models show that a coseismic temperature spike drops to the background temperature within 2 seconds (Demurtas et al., 2019). However, the formation of crystallographic preferred orientations (CPOs), generally connected with operation of dislocation creep, have been reported continuously from carbonate fault gouges deformed under brittle conditions in lab and nature and from seismic to subseismic velocities (Smith et al., 2013; Verberne et al., 2013; Delle Piane et al., 2018; Kim et al., 2018; Demurtas et al., 2019; Pozzi et al., 2019). The CPOs reported typically involve alignment of (0001) planes and $<\overline{1} 2 \overline{1} 0>$ axes subparallel to the shear plane with an antithetic inclination of (0001)-plane normals against the shear direction. There appears to be a discrepancy between the previous assignment of exclusively brittle processes mostly covering grain fracturing and the reoccurrence of the same CPOs commonly indicative of dislocation slip systems and dislocation rearrangement in subgrains. Throughout this study we will make use of slip system analyses in calcite and quartz. As a brief summary, Figure 3 illustrates the different crystallographic directions and the associated misorientation inverse pole figure (MIPF) rotation axis clusters of different types of dislocations from corresponding slip systems. However, other mechanisms have been proposed, e.g., oriented attachment through the maximisation of shared lattice sites (Toy et al., 2015). In Chapters 2, 3 and 4 we will analyse the CPOs of seismically deformed cataclasites and will discuss the CPO formation mechanisms in detail.

The influence of fluids on deformation is crucial because crustal fault zones can be fluid-permeability structures (Caine et al., 1996). The effect of additional water in quartzites is reported by Tokle et al. (2019) showing a reduction in friction. Blacic (1975) proposed the favoured activation of slip systems in [0001] direction by elevated hydroxyl-group content in quartz. Stünitz et al. (2017) propose fluidweakening through $\mathrm{H}_{2} \mathrm{O}$-assisted dislocation generation. The examples above suggest that fluids in fault zones may influence crystal-plastic deformation. In addition, elevated contents of water for minerals from the Earth's mantle, namely olivine, can change the type of slip system active under given deformation conditions (Jung and Karato. 2001). However, reports on the influence of water on calcite deformation is lacking.

High-velocity friction experiments of carbonate rocks often report a characteristic dynamic weakening, marked by a sharp drop in fault friction (Han, et al., 2007a, 2007b; Smith et al., 2015; Spagnuolo et al., 2015; Chen et al., 2017; Rempe et 
al., 2017; Demurtas et al., 2019). To date, the processes leading to dynamic weakening in carbonate rocks are still not well constrained and experiments by Chen et al. (2017) and Rempe et al. (2017) suggest that dynamic weakening is stronger in wet experiments. Experiments targeting this weakening behaviour are mostly focused on interpretation of mechanical data but micro-, and nanostructural investigations of dynamic weakening mechanisms are still lacking. In Chapter 3, we will review the potential underlying mechanisms that may contribute to the observed dynamic weakening during wet, coseismic carbonate deformation and extend the previous deformation studies by including nanoscale physico-chemical reactions during rock deformation under hydrous conditions.
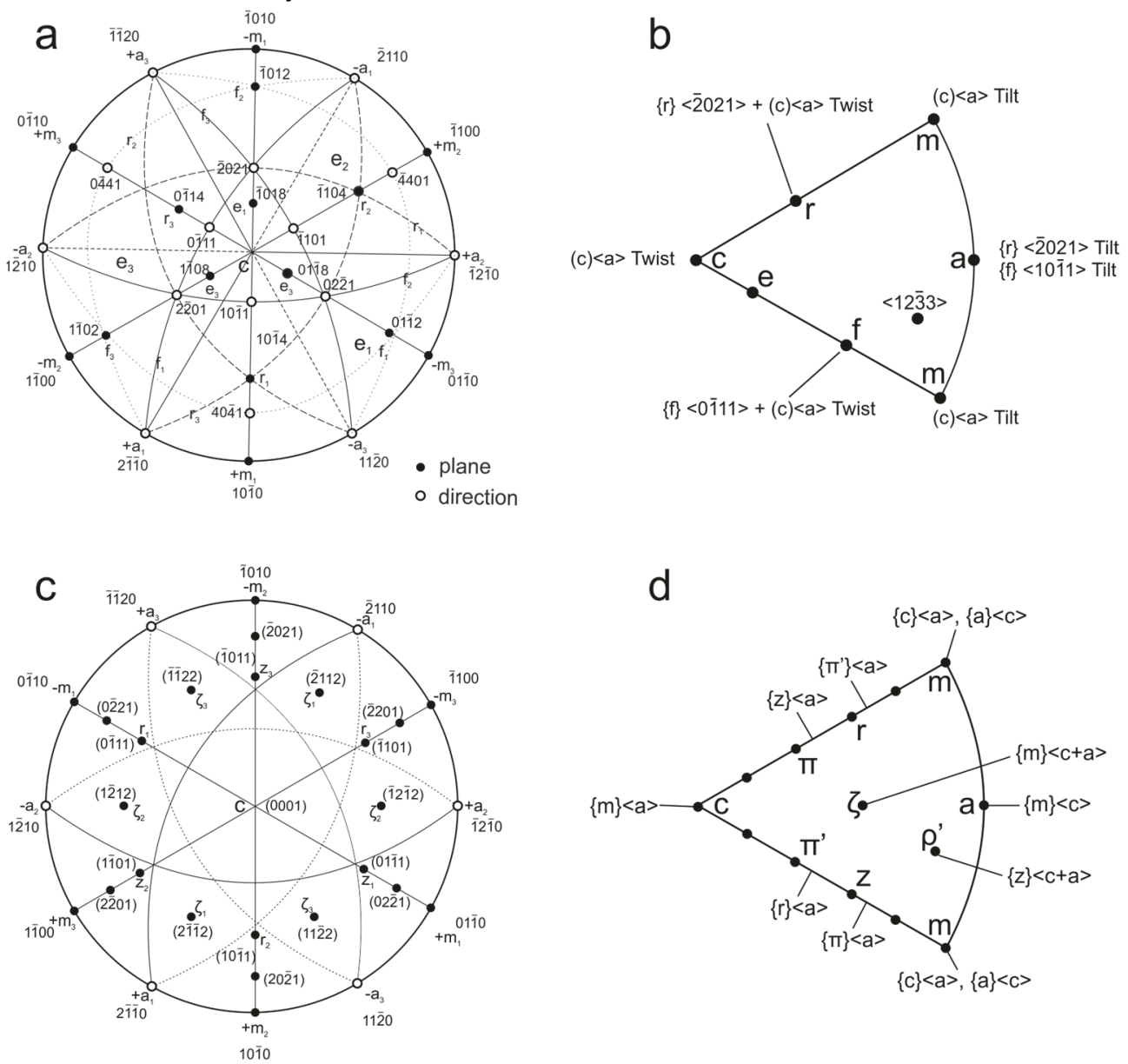

Figure 3: Overview of crystallography and slip systems of calcite (a: and b:) and $\alpha$-quartz (c: and d:). a: Stereographic projection of relevant crystal directions in calcite. Modified after De Bresser and Spiers (1997). $\underline{\boldsymbol{b}}$ : Inverse pole figure indicating rotation for potential calcite slip systems. $\underline{\text { : }}$ Stereographic projection of relevant crystal directions in quartz. Modified after Minor et al. (2018). d: Inverse pole figure indicating rotation axes for potential slip systems in quartz. Modified after Neumann (2000). 
State-of-the-art deformation models have been published by Sammis and Ben-Zion (2008) for fault gouge formation and for fault gouge deformation by De Paola et al. (2015), Chen and Spiers (2016) and Pozzi et al. (2018). The model by Sammis and Ben-Zion (2008) is based on the development of force chains, the building of a load-bearing framework and how particles fracture with respect to grain size and material. This model is relevant during the early stages of fault gouge formation by grain-size reduction. The models by De Paola et al. (2015) and Pozzi et al. (2018) describe the deformation of the fault gouge through a transition from grain-size insensitive dislocation creep to grain-size sensitive creep deformation with the addition of thermally activated grain-boundary sliding mechanisms. Pozzi et al. (2018) refines this model and proposes an additional piezometric relationship during the evolution of grain sizes to lower particle sizes. The mentioned models by De Paola et al. (2015) and Pozzi et al. (2018) are derived from experimental faults deformed under dry conditions. The Chen-Niemeijer-Spiers (CNS) model published by Chen and Spiers (2016) does incorporate fluid-rock interactions and considers nanoscale dissolution and diffusion processes. However, most microphysical models do not account for fluid-rock interactions at seismic velocities and leave, therefore, an incomplete picture of the deformation processes in fluid-saturated fault zones.

Chen et al. (2017) reports a considerable friction reduction in wet, fluidsaturated experiments on calcite fault gouge and considers coseismic fluid-phase transitions. The hypothesis of the study is that the temperature-increase of a fault could be fluid-buffered, and the temperature should evolve along the saturated water-vapour phase boundary. However, the degree of fluid-buffered temperature increase also depends on the boundary conditions and may vary with normal stress, permeability, or experiment setup (Chen et al., 2017). The main implication of the results is that frictional heating could be capped by the physical phase transition from liquid water to water vapour until the phase transition is complete. With this basic, physical principle it becomes immediately clear that a fault needs to first run dry before frictional heating will reach higher temperatures, e.g., for melting or thermal decarbonation. Until the point of complete fluid vaporisation, decomposition products will likely interact with the fluid and may be able to produce a physico-chemical feedback loop, where the resulting phases from fluid interaction will affect fault slip, interseismic healing and fault reactivation, influencing the whole seismic cycle. 
The first two chapters of this thesis are based on natural samples from field work we conducted at the end of 2016. During this time, we sampled two carbonatehosted fault mirrors from tectonically active fault zones in Central Greece. The first fault exposure of Arkitsa is part of the Agios Konstantinos fault zone, which produces a complex stress field in combination with the extension of the North Anatolian fault zone stretching over from Turkey. The location of Arkitsa lies close to the historic location of Thermopylae, known for the battle of the Spartans, led by Leonidas against the Persians in $480 \mathrm{BC}$. The second Greek fault exposure is located close to Schinos and is part of the extensional structures related to the spreading of the Gulf of Corinth. The third chapter describes and analyses the interaction of pore fluids with calcite-fault gouge during seismic and subseismic deformation. The utilisation of water strongly enriched with the stable-oxygen isotope ${ }^{18} \mathrm{O}$ enables us to track and identify transient fluid-rock interactions. The fourth chapter is based on fieldwork conducted in mid-2018 where we sampled silicate-based fault mirrors in several locations across the western United States of America (USA). The research presented in Chapter 4 is focused on samples taken from Dixie Valley, western Basin-Range Province. Sampling during full summer in Dixie Valley, Nevada is something we cannot recommend repeating because of the daily peak temperatures.

\section{References}

Beckmann, P. and Spizzichino, A., 1987. The scattering of electromagnetic waves from rough surfaces. Norwood, MA: Artech House.

Blacic, J. D., 1975. Plastic-deformation mechanisms in quartz: the effect of water. Tectonophysics. 27, 271-294.

Blenkinsop, T. G., 1991. Cataclasis and processes of particle size reduction. Pure and Applied Geophysics. 136, 59-86.

Brace, W. F. and Byerlee, J. D., 1966. Stick-slip as a mechanism for earthquakes. Science. 153, 990-992.

Broz, M. E., Cook, R. F., Whitney, D. L., 2006. Microhardness, toughness, and modulus of Mohs scale minerals. American Mineralogist. 91, 135-142.

Bullock, R. J., De Paola, N., Holdsworth, R. E., Trabucho-Alexandre, J., 2014. Lithological controls on the deformation mechanisms operating within carbonate-hosted faults during the seismic cycle. Journal of Structural Geology. $58,22-42$. 
Caine, J. S., Evans, J. P., Forster, C. B., 1996. Fault zone architecture and permeability structure. Geology. 24, 1025-1028.

Chen, J., Niemeijer, A., Yao, L., Ma, S., 2017. Water vaporization promotes coseismic fluid pressurization and buffers temperature rise. Geophysical Research Letters. 44, 2177-2185.

Chen, J. and Spiers, C. J., 2016. Rate and state frictional and healing behavior of carbonate fault gouge explained using microphysical model. Journal of Geophysical Research: Solid Earth. 121, 8642-8665.

Cowan, D. S., 1999. Do faults preserve a record of seismic slip? A field geologist's opinion. Journal of Structural Geology. 8, 995-1001.

De Bresser, J. and Spiers, C. J., 1997. Strength characteristics of the r, f, and c slip systems in calcite. Tectonophysics. 272, 1-23.

De Paola, N., Holdsworth, R. E., Viti, C., Collettini, C., Bullock, R., 2015. Can grain size sensitive flow lubricate faults during the initial stages of earthquake propagation? Earth and Planetary Science Letters. 431, 48-58.

Delle Piane, C., Piazolo, S., Timms, N. E., Luzin, V., Saunders, M., Bourdet, J., Giwelli, A., Clennell, M. B., Kong, C., Rickard, W. D., 2018. Generation of amorphous carbon and crystallographic texture during low-temperature subseismic slip in calcite fault gouge. Geology. 46, 163-166.

Demurtas, M., Smith, S. A., Prior, D. J., Spagnuolo, E., Di Toro, G., 2019. Development of crystallographic preferred orientation during cataclasis in low-temperature carbonate fault gouge. Journal of Structural Geology. 126, 3750 .

Di Toro, G., Han, R., Hirose, T., De Paola, N., Nielsen, S., Mizoguchi, K., Ferri, F., Cocco, M., Shimamoto, T., 2011. Fault lubrication during earthquakes. Nature. $471,494$.

Dickinson, J. T., Jensen, L. C., Langford, S. C., Rosenberg, P. E., Blanchard, D. L., 1991. $\mathrm{CO}_{2}$ emission accompanying the fracture of calcite. Physics and Chemistry of Minerals. 18, 320-325.

Fagereng, А̊ and Toy, V. G., 2011. Geology of the earthquake source: an introduction. Geological Society, London, Special Publications. 359, 1-16.

Ferraro, F., Grieco, D. S., Agosta, F., Prosser, G., 2018. Space-time evolution of cataclasis in carbonate fault zones. Journal of Structural Geology. 110, 45-64.

Han, R., Shimamoto, T., Hirose, T., Ree, J., Ando, J., 2007a. Ultralow friction of carbonate faults caused by thermal decomposition. Science. $316,878-881$. 
Han, R., Shimamoto, T., Ando, J., Ree, J., 2007b. Seismic slip record in carbonatebearing fault zones: An insight from high-velocity friction experiments on siderite gouge. Geology. 35, 1131-1134.

Han, R., Hirose, T., Shimamoto, T., 2010. Strong velocity weakening and powder lubrication of simulated carbonate faults at seismic slip rates. Journal of Geophysical Research: Solid Earth. 115.

Hall, E. O., 1951. The Deformation and Ageing of Mild Steel: III Discussion of Results. Proceedings of the Physical Society, Section B, 64. 9, 747-753.

Heyliger, P., Ledbetter, H., Kim, S., 2003. Elastic constants of natural quartz. The Journal of the Acoustical Society of America. 114, 644-650.

Jung, H. and Karato, S., 2001. Water-induced fabric transitions in olivine. Science. 293, 1460-1463.

Kim, S., Ree, J., Han, R., Kim, N., Jung, H., 2018. Fabric transition with dislocation creep of a carbonate fault zone in the brittle regime. Tectonophysics. 723, 107116.

Kunitake, M., 2015. The Effects Of Structure And Composition On The Hardness Of Biogenic And Synthetic Single Crystal Calcite. PhD thesis, Cornell University, https://hdl.handle.net/1813/41130

Manzano, H., Pellenq, R. J., Ulm, F., Buehler, M. J., van Duin, A. C., 2012. Hydration of calcium oxide surface predicted by reactive force field molecular dynamics. Langmuir. 28, 4187-4197.

Martinelli, G. and Plescia, P., 2004. Mechanochemical dissociation of calcium carbonate: laboratory data and relation to natural emissions of $\mathrm{CO}_{2}$. Physics of the Earth and Planetary Interiors. 142, 205-214.

Minor, A., Rybacki, E., Sintubin, M., Vogel, S., Wenk, H., 2018. Tracking mechanical Dauphiné twin evolution with applied stress in axial compression experiments on a low-grade metamorphic quartzite. Journal of Structural Geology. 112, 8194.

Mitchell, T. M. and Faulkner, D. R., 2009. The nature and origin of off-fault damage surrounding strike-slip fault zones with a wide range of displacements: A field study from the Atacama fault system, northern Chile. Journal of Structural Geology. 31, 802-816.

Neumann, B., 2000. Texture development of recrystallised quartz polycrystals unravelled by orientation and misorientation characteristics. Journal of Structural Geology. 22, 1695-1711. 
Nielsen, S., 2017. From slow to fast faulting: recent challenges in earthquake fault mechanics. Philosophical Transactions of the Royal Society A, 375: 20160016.

Petch, N. J., 1953. The Cleavage Strength of Polycrystals, Journal of the Iron and Steel Institute, 174, 25-28.

Pozzi, G., De Paola, N., Nielsen, S. B., Holdsworth, R. E., Bowen, L., 2018. A new interpretation for the nature and significance of mirror-like surfaces in experimental carbonate-hosted seismic faults. Geology. 46.7, 583-586.

Pozzi, G., De Paola, N., Holdsworth, R. E., Bowen, L., Nielsen, S. B., Dempsey, E. D., 2019. Coseismic ultramylonites: An investigation of nanoscale viscous flow and fault weakening during seismic slip. Earth and Planetary Science Letters. 516, 164-175.

Reches, Z. and Lockner, D. A., 2010. Fault weakening and earthquake instability by powder lubrication. Nature. 467, 452-455.

Rempe M., Smith S., Mitchell T., Hirose T., Di Toro G., 2017. The effect of water on strain localization in calcite fault gouge sheared at seismic slip rates. Journal of Structural Geology. 97, 104-117.

Rice, J. R., 2006. Heating and weakening of faults during earthquake slip. Journal of Geophysical Research: Solid Earth. 111, B5.

Rodriguez-Navarro, C., Ruiz-Agudo, E., Luque, A., Rodriguez-Navarro, A. B., Ortega-Huertas, M., 2009. Thermal decomposition of calcite: Mechanisms of formation and textural evolution of $\mathrm{CaO}$ nanocrystals. American Mineralogist. 94, 578-593.

Sammis, C. G. and Ben-Zion, Y., 2008. Mechanics of grain-size reduction in fault zones. Journal of Geophysical Research: Solid Earth. 113, B2.

Sammis, C., King, G., Biegel, R., 1987. The kinematics of gouge deformation. Pure and Applied Geophysics. 125, 777-812.

Sibson, R. H., 2003. Thickness of the seismic slip zone. Bulletin of the Seismological Society of America. 93, 1169-1178.

Sibson, R. H., 1986. Brecciation processes in fault zones: inferences from earthquake rupturing. Pure and Applied Geophysics. 124, 159-175.

Siman-Tov, S., Aharonov, E., Sagy, A., Emmanuel, S., 2013. Nanograins form carbonate fault mirrors. Geology. 41, 703-706.

Smeraglia, L., Bettucci, A., Billi, A., Carminati, E., Cavallo, A., Di Toro, G., Natali, M., Passeri, D., Rossi, M., Spagnuolo, E., 2017. Microstructural evidence for 
seismic and aseismic slips along clay-bearing, carbonate faults. Journal of Geophysical Research: Solid Earth. 122.5, 3895-3915.

Smith, S., Di Toro, G., Kim, S., Ree, J., Nielsen, S., Billi, A., Spiess, R., 2013. Coseismic recrystallization during shallow earthquake slip. Geology. 41, 63-66.

Smith S., Nielsen S., Di Toro G., 2015. Strain localization and the onset of dynamic weakening in calcite fault gouge. Earth and Planetary Science Letters. 413, 2536.

Spagnuolo E., Plümper O., Violay M., Cavallo A., Di Toro G., 2015. Fast-moving dislocations trigger flash weakening in carbonate-bearing faults during earthquakes. Scientific reports 5, 16112.

Stünitz, H., Thust, A., Heilbronner, R., Behrens, H., Kilian, R., Tarantola, A., Fitz Gerald, J. D., 2017. Water redistribution in experimentally deformed natural milky quartz single crystals-Implications for $\mathrm{H}_{2} \mathrm{O}$-weakening processes. Journal of Geophysical Research: Solid Earth. 122.2, 866-894.

Tokle, L., Hirth, G., Behr, W. M., 2019. Flow laws and fabric transitions in wet quartzite. Earth and Planetary Science Letters. 505, 152-161.

Toy V.G., Mitchell T.M., Druiventak A., Wirth R., 2015. Crystallographic preferred orientations may develop in nanocrystalline materials on fault planes due to surface energy interactions. Geochemistry. Geophysics. Geosystems 16, 25492563.

Verberne, B. A., Spiers, C. J., Niemeijer, A. R., De Bresser, J., De Winter, D., Plümper, O., 2014. Frictional properties and microstructure of calcite-rich fault gouges sheared at sub-seismic sliding velocities. Pure and Applied Geophysics. 171, 2617-2640.

Verberne, B. A., de Bresser, J. H., Niemeijer, A. R., Spiers, C. J., de Winter, D. M., Plümper, O., 2013. Nanocrystalline slip zones in calcite fault gouge show intense crystallographic preferred orientation: Crystal plasticity at sub-seismic slip rates at $18-150{ }^{\circ} \mathrm{C}$. Geology. $41,863-866$.

Yao L., Ma S., Niemeijer A.R., Shimamoto T., Platt J.D., 2016. Is frictional heating needed to cause dramatic weakening of nanoparticle gouge during seismic slip? Insights from friction experiments with variable thermal evolutions. Geophysical Research Letters. 43, 6852-6860. 


\section{Chapter 1: Mechanisms of fault mirror formation and fault healing in carbonate rocks}

This chapter is published as the following publication: Ohl, M., Plümper, O., Chatzaras, V., Wallis, D., Vollmer, C., E Drury, M. (2020). Mechanisms of fault mirror formation and fault healing in carbonate rocks. Earth and Planetary Science Letters, 530, 115886. DOI: 10.1016/j.epsl.2019.115886. 


\section{Abstract}

The development of smooth, mirror-like surfaces provides insight into the mechanical behaviour of crustal faults during the seismic cycle. To determine the thermo-chemical mechanisms of fault mirror formation, we investigated carbonate fault systems in seismically active areas of central Greece. Using multi-scale electron microscopy combined with Raman and electron energy loss spectroscopy, we show that fault mirror surfaces do not always develop from nanogranular volumes. The microstructural observations indicate that decarbonation is the transformation process that leads to the formation of smooth surface coatings in the faults studied here. Piercement structures on top of the fault surfaces indicate calcite decarbonation, producing $\mathrm{CO}_{2}$ and lime $(\mathrm{CaO})$. Lime subsequently reacts to portlandite $\left(\mathrm{Ca}(\mathrm{OH})_{2}\right)$ under hydrous conditions. Nanoscale imaging and electron diffraction reveal a thin coating of a non-crystalline material sporadically mixed with nano-clay, forming a complex-composite material that smooths the slip surface. Spectroscopic analyses reveal that the thin coating is non-crystalline carbon. We suggest that ordering (hybridisation) of amorphous carbon led to the formation of partly-hybridised amorphous carbon but did not reach full graphitisation. Calcite nanograins, $<50 \mathrm{~nm}$ in diameter, are spatially associated with the carbon and indicate that the decomposition products acted as a crystallisation medium. Within this medium, portlandite back-reacted with $\mathrm{CO}_{2}$ to form nanocrystalline calcite. Consequently, two types of calcite nanograins are present: nanograins formed by grain-size reduction (primary nanograins, $>100 \mathrm{~nm}$ ) and new nanograins formed by back-reaction (secondary nanograins, $<50 \mathrm{~nm}$ ). Hence, we suggest that the new, secondary nanograins are not the result of comminution during slip but originate from pseudomorphic replacement of calcite after portlandite. The continuous coverage of partly-hybridised amorphous carbon on all samples suggests that calcite decarbonation products may develop across the entire fault surface, controlling the formation of carbonate fault mirrors, and may facilitate slip on a decarbonationproduct glide film.

\subsection{Introduction}

Brittle deformation of upper-crustal rocks can result in high-magnitude seismic events (Scholz, 1998). Mirror slip surfaces (MSSs) along principal slip zones in carbonate rocks provide an excellent opportunity to investigate the deformation processes that occur in relation to slip events in the seismogenic zone. Carbonate- 
hosted faults can produce seismic events with magnitudes of $M_{w}=6$ and greater. These events present a hazard to populated regions, such as the Mediterranean. The defining feature of MSSs is the high degree of visible-light reflectance resulting from a low surface roughness. MSSs can form at seismic slip velocities and, therefore, may indicate paleo-seismicity (Siman-Tov et al., 2013; Smith et al., 2013; Fondriest et al., 2013; Kirkpatrick et al., 2013; Spagnuolo et al., 2015). However, MSS have also been developed at sub-seismic slip conditions in deformation experiments (Tisato et al., 2012; Verberne et al., 2014) and, thus, they are not necessarily diagnostic of seismic slip.

The studies from Siman-Tov et al. (2013), Collettini et al. (2014) and Verberne et al. (2014) suggest that the low surface roughness of MMS may be the result of nano-sized grains $(<1 \mu \mathrm{m})$, which constitute the uppermost layers of many principal slip surfaces. However, work by Fondriest et al. (2013) demonstrates that truncated, large grains can be part of mirror surfaces as well, illustrating that the formation of ultra-polished surfaces does not necessitate a nanograin coating along the slip surface. In addition, nanogranular coatings are also produced in deformation experiments under seismic conditions (Green et al., 2015; Spagnuolo et al., 2015). Therefore, the formation of natural MSSs has been associated with the development of a nanogranular slip-surface coating during seismic events. These nanogranular coatings may in addition control the frictional behaviour of the fault (Han et al., 2007a, b; Han et al., 2010; Di Toro et al., 2011; Bullock et al., 2014; De Paola et al., 2015; Smeraglia et al., 2017).

Current research suggests different formation mechanisms for carbonate mirror slip surfaces: (1) Formation of elongate, twin-derived beams by plasticity and subsequent brittle fracturing of the beams to form a nanograin coating (Siman-Tov et al., 2013) and (2) localised dynamic recrystallisation and static recrystallisation (Smith et al., 2013). Several studies have reported decarbonation products during or after experiments that produced fault mirrors (Han et al., 2007a and b, De Paola et al., 2011, Smith et al., 2013, Fondriest et al., 2013, Delle Piane et al., 2017). Pluymakers and Røyne (2017) found an increase in nanospherules (nanoparticles) responsible for reducing the surface roughness after heating, which demonstrates that existing mirror slip surfaces could be affected by heating events. These studies suggest that the formation of nanograins and fault mirrors are intrinsically linked, tying the formation of mirror slip surfaces to the formation of nanograins. 
One of the main mechanisms of fault-gouge formation is grain-size reduction by comminution. Reduction of grain size commences by inducing fractures at grain-to-grain contacts, which then break the grains. The grain-size dependence of the modified Hall-Petch relation proposed by Sammis and Ben-Zion (2008) illustrates that smaller grains require higher differential stresses to fracture. Therefore, local stress concentrations during co-seismic events may be favourable sites for the generation of nanograins by fracturing micron to millimetre-sized grains. Because of the high stress concentrations during earthquakes, nanograins may be evidence for paleo-seismic events.

Less commonly considered effects of fault-rock deformation in carbonates are thermo-mechanical processes, e.g., decarbonation. Products of decarbonation processes are reported from experiments (Han et al., 2007a and b; De Paola et al., 2011; Verberne et al., 2014; Spagnuolo et al., 2015; Delle Piane et al., 2017) and from natural faults (Vigano et al., 2011; Collettini et al., 2013). The experimental studies of Verberne et al. (2014), Spagnuolo et al. (2015) and Delle Piane et al. (2017) report the presence of amorphous carbon as a deformation product and Han et al., (2007a) mention the presence of portlandite $\left(\mathrm{Ca}(\mathrm{OH})_{2}\right)$. Some natural faults also exhibit amorphous glass coatings around euhedral calcite crystals in potential carbonate pseudotachylites (Vigano et al., 2011). In addition, deformation experiments on silicates (Yund et al., 1990; Di Toro et al., 2004; Pec et al., 2012; Hirose et al., 2012; Toy et al., 2015) produce non-crystalline or partly-amorphous silicate materials (Pec et al., 2012).

We investigated the surface and the underlying few tens of micrometres of two natural carbonate fault-mirror structures to test the hypothesis of a nanogranular surface coating. Our high-resolution electron microscopy and Raman spectroscopy analyses demonstrate that a thin coating of decarbonation products is able to produce a MMS without a nanogranular surface coating, similar to the results of Fondriest et al. (2013). In addition, we suggest that the amorphous products may facilitate and lubricate seismic slip (De Paola et al., 2011; Di Toro et al., 2011) while being produced or possibly re-strengthen the fault by post-seismic recrystallisation of the decomposition products during the inter-seismic period. 


\subsection{Geological Setting}

\subsubsection{Geology of the Arkitsa fault zone}

The $700 \mathrm{~m}$ long Arkitsa fault surface exposure (Fig. 1A) belongs to the Kamena Vourla fault system; a northward-dipping, ESE-WNW striking, active normal fault zone of approximately $50 \mathrm{~km}$ length along the southern coast of the Gulf of Evia. This left-stepping fault system consists of the Kamena Vourla, the Agios Konstantinos and the Arkitsa fault segments (Roberts and Jackson, 1991; Ganas et al., 1998). The study area $\left(38^{\circ} 43^{\prime} 56.17^{\prime \prime} \mathrm{N}, 23^{\circ} 0^{\prime} 27.41^{\prime \prime} \mathrm{E}\right)$ is situated within the Pelagonian zone of Central Greece. In general, the Arkitsa fault planes juxtapose Late Triassic to Middle/Late Jurassic platform carbonates in the footwall with lower Pliocene-Pleistocene to Quaternary sediments in the hanging wall (Kokkalas et al., 2007). The Arkitsa fault scarp itself is an anthropogenically formed fault exposure first described by Jackson and McKenzie (1999). Quarrying for two decades removed a major part of the hanging-wall colluvium to reveal three large, smooth fault planes of up to $65 \mathrm{~m}$ height (Kokkalas et al., 2007).

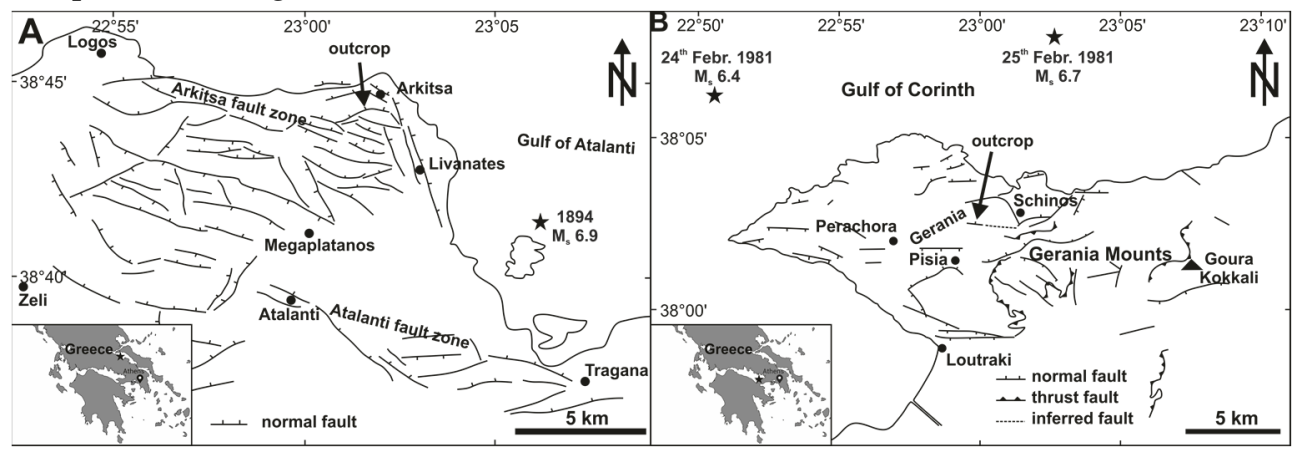

Figure 1: Tectonic maps of the study areas. Insets show the geographical location within central Greece. A: Location of the studied exposure of the Arkitsa fault zone (modified after Jones et al., 2009; earthquake data: NOAA). B: Outcrop location of the Schinos fault segment north of Corinth (modified after Kaplanis et al., 2013 and Collier et al., 1998).

Historical records of seismicity in the Gulf of Evia area indicate about 13 rupture events from 426 BC until the last major event in 1894 (Ganas et al., 1998; Ganas et al., 2006), with a magnitude $\mathrm{M}_{\mathrm{s}} 6.9$ earthquake hosted within the Atalanti fault zone (Fig. 1A) (Ambraseys and Jackson, 1990). This number of events fits with the approximately 50 slip increments identified by Jackson and McKenzie (1999), where the authors calculated the slip increments from fault plane height and average earthquake slip distances. Evidence for Holocene seismic activity along the Arkitsa 
fault planes is recorded by the approximately $1 \mathrm{~m}$ unweathered fault scarp existing prior to quarrying (Jones et al., 2009).

\subsubsection{Geology of the Schinos fault zone}

The Schinos fault zone is located north-east of Corinth within the Gerania mountains, with the studied exposure ( $\left.38^{\circ} 2^{\prime} 14.40^{\prime \prime} \mathrm{N}, 23^{\circ} 0^{\prime} 22.33^{\prime \prime} \mathrm{E}\right)$ belonging to the Gerania unit of the Internal Hellenides (Kaplanis et al., 2013). Formation of the 120 $\mathrm{m}$ long fault exposure is from material excavation for the adjacent dirt road. The fault plane is an east-west striking, northward-dipping normal fault plane hosted within Upper Triassic limestones and dolomites. The stratigraphic succession of the Gerania unit includes from bottom to top: Permian sedimentary and volcanic rocks, Upper Triassic neritic limestones and dolomites, Lower Jurassic limestones, an Upper Jurassic succession of rift-related sediments overlain by either Ammonitico Rosso (Bathonian or Oxfordian age) or radiolarian sediments, and ophiolite-derived turbidites of the Beotian flysch (Kaplanis et al., 2013).

Seismicity data record an earthquake sequence in the Corinth region with three main shocks: 24th February $1981, M_{s} 6.7 ; 25^{\text {th }}$ February $1981, M_{s} 6.4$ and $4^{\text {th }}$ March 1981, Ms 6.4 (Collier et al., 1998). Based on the epicentral location and a mismatch between the focal mechanism Collier et al. (1998) interpreted that the $24^{\text {th }}$ February event started with displacement on an offshore fault and continued to rupture the Pisia fault, producing a surface break. In addition, Collier et al. (1998) propose the same succession of events for the $25^{\text {th }}$ of February event, which caused a displacement on the Schinos fault, probably forming the most recent event on the fault plane that we study here.

\subsection{Methods}

We analysed drill-core samples from the Arkitsa and Schinos fault exposures using a range of micro-analytical techniques. In total, 40 drill cores, 2.54 $\mathrm{cm}$ in diameter, were collected from the Arkitsa fault zone and, 18 were collected from the Schinos fault zone. The maximum retrievable drill-core lengths did not exceed $10 \mathrm{~cm}$ (Arkitsa) and $5 \mathrm{~cm}$ (Schinos) as the porosity of the fault rock increases, and the material loses its cohesion with distance from the fault surfaces. Seven samples from the Arkitsa fault zone and four samples from the Schinos fault zone were chosen for further investigation based on the best-preserved mirror surfaces. 
Sample cores were sputter coated with an 8-nm thick layer of platinum/palladium for charge deduction.

From both faults, two representative samples were selected for electrontransparent foil preparation using a FEI Helios Nanolab G3 Dualbeam focused ion beam scanning electron microscope (FIB-SEM). Prior to ion beam deposition of the main platinum strip, a 200-nm layer of platinum was deposited using the electron beam $(2 \mathrm{kV}, 0.4 \mathrm{nA})$ to prevent surface amorphisation by the ion beam as a preparation artefact. Transmission electron microscope (TEM) investigations of the foils were carried out with a FEI Talos F200X. TEM images were acquired with 200 $\mathrm{kV}$ acceleration voltage and $5 \mathrm{nA}$ or $10 \mathrm{nA}$ beam current depending on final sample thickness. The FEI Talos SuperEDX detector was used for chemical element mapping via energy dispersive X-rays (EDX) in scanning transmission electron microscope (STEM) mode. EDX maps were quantified post-acquisition with Bruker Esprit 1.9 software using the Cliff-Lorimer approximation and ImageJ.

Electron energy loss spectroscopy (EELS) data were acquired with a Zeiss Libra 200FE in TEM mode at $200 \mathrm{kV}$ with an Omega in-column energy filter. The energy resolution of EELS analyses was $0.7 \mathrm{eV}$, measured at the full width half maximum (FWHM) of the zero-loss peak. Energy loss spectra were obtained at 250,000x magnification with a $100 \mu \mathrm{m}$ filter-entrance aperture giving an effective aperture of about $40 \mathrm{~nm}$ on the sample. The convergence angle of EELS was about 0.1 milliradian (mrad), and the acceptance angle was defined by the $60 \mu \mathrm{m}$ diameter of the objective aperture giving a collection angle of 11.6 mrad. Measurement times of EEL spectra were set to 1-5 s, with 5-10 frames/spectrum, on a slow-scan CCD (model UltraScan 4000), with binning of 4x4 pixels (giving 1024 pixels), and an energy spread of $0.08 \mathrm{eV} /$ pixel, resulting in an energy range of $82 \mathrm{eV}$ in the acquired spectra. Spectra were deconvolved with the zero-loss peak to remove the effect of plural scattering and background-subtracted assuming a power law function with Gatan's Digital Micrograph software.

Raman spectroscopy was carried out with a WiTec ALPHA300 R confocal microscope to identify and characterize possible reaction or decomposition products on the fault surfaces. We used a laser with a wavelength of $532 \mathrm{~nm}$ and a spectral grating of 600 grooves/mm. Data acquisition, data post-processing and peak fitting were performed with WiTec ProjectFour 4.1 software and Fityk 0.98 (Wojdyr, 2010) peak fitting software. In accordance with Ferrari and Robertson (2000) we 
determined the intensity ratios of the D to $G$ peak, $\frac{I(D)}{I(G)}$, to obtain information about the degree of crystallinity within carbon phases. We used the approach by Ferrari and Robertson (2000) based on first principle considerations to determine the peak height ratios because the information about the less disordered aromatic rings and the clustering of the $\mathrm{sp}^{2}$ phase is contained in the intensity maximum of the $\mathrm{D}$ peak and not in the width. Surface roughness measurements were executed within a Nanoscope atomic force microscope (AFM). Calculation of reaction enthalpy values were executed with SUPCRT92 (Johnson et al., 1992) at standard conditions (1 bar, 298 K).

\subsection{Results}

\subsubsection{Field results}

The exposed surface of the Arkitsa fault (Fig. 2A) exhibits a range of sliprelated structures. At outcrop scale, the fault plane exposure steps over, which suggests the presence of several slip planes inside the fault damage zone. The fault surface contains pronounced slip grooves parallel to the direction of oblique slip. Fractures with a spacing on the order of one metre are oriented approximately perpendicular to the grooves (Fig. 2A). Parts of the slip plane are covered with residual reddish-brown hanging-wall breccia, incorporating fragments of dark hostrock carbonate up to several decimetres in size (Fig. 2A). The most prominent feature is the low roughness of the fault surface, which enables the reflection of sunlight (Fig. 2B). The fault rock is a matrix-supported, greyish cataclasite with dark carbonate clasts up to several centimetres in size (Fig. 2C). Slip-parallel alignment of clasts on the fault surfaces can be traced over several meters (Fig. 2C).

The Schinos fault surface (Fig. 2D) exhibits a range of structures formed during slip. We observe stepovers, indicating the presence of several fault planes inside the fault damage zone. The fault surface is extremely smooth with areas not only reflecting light but also mirroring the surrounding vegetation (Fig. 2E). Fragments of grey carbonate host rock are incorporated into the red-orange footwall cataclasite. The clasts are strongly aligned in the slip direction and usually do not exceed 1-2 cm in size (Fig. 2F). The fault surface contains pronounced slip grooves and a wavy surface morphology (Fig. 2D). The mirror surfaces of both faults are hosted inside a zone of high competence with average thicknesses of $10 \mathrm{~cm}$ and $5 \mathrm{~cm}$ for the Arkitsa and Schinos faults, respectively. 


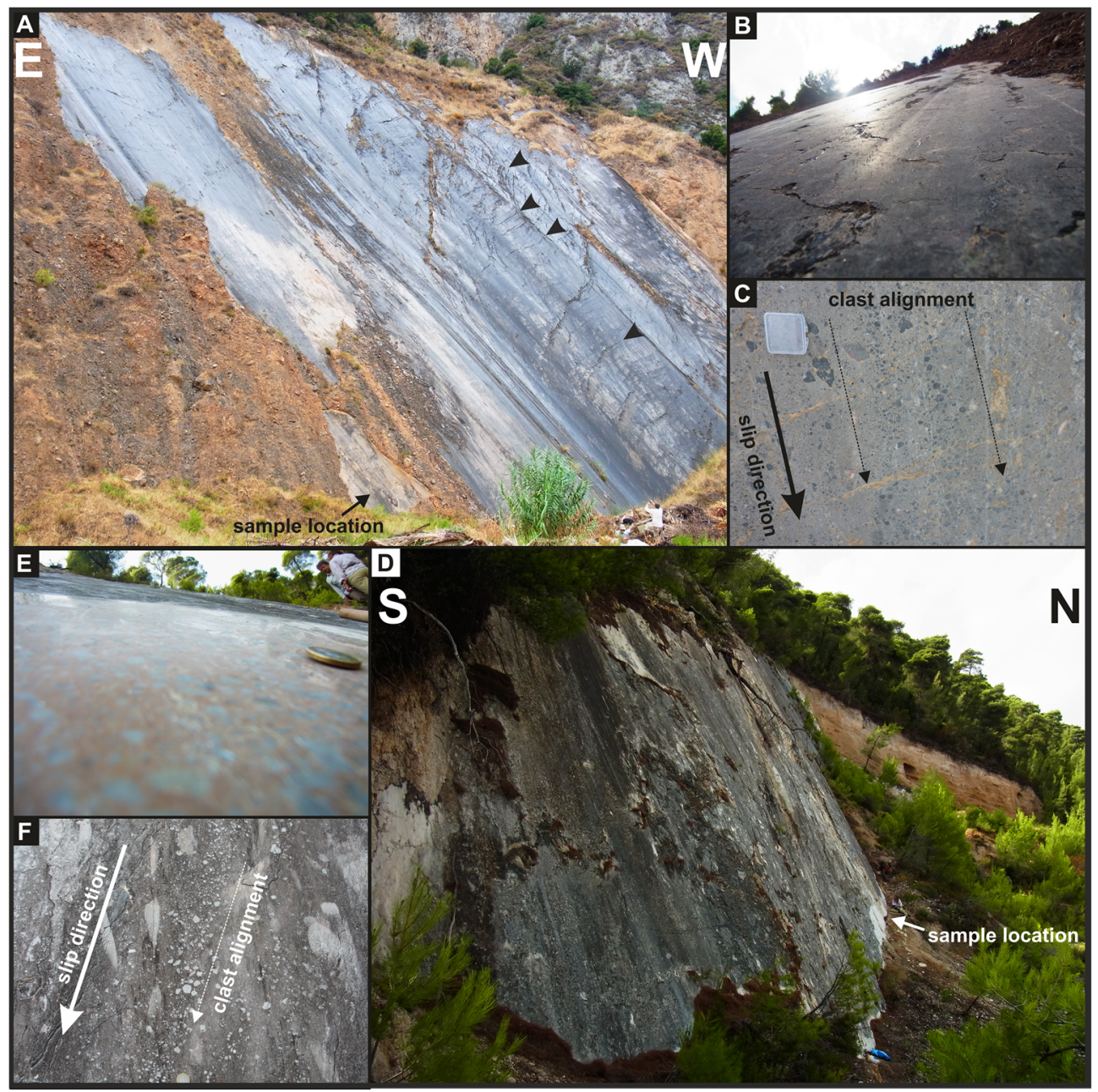

Figure 2: Representative field structures from Arkitsa $(A-C)$ and Schinos $(D-F)$ fault exposures. A: Overview of Arkitsa fault exposure showing one of the three main slip planes with reddish-brown hanging-wall breccia cover on part of the slip surface. Black arrows indicate fractures perpendicular to slip direction. Person for scale, bottom right corner. B: Fault surface reflecting sunlight. C: Alignment of host-rock fragments parallel to slip direction. Box approx. $5 \times 4 \mathrm{~cm}$. D: Schinos fault surface exposure shows grey weathering of the slip plane. The slip plane is curved with the salient pointing out of the figure. Fault scarp to the north is now covered by alluvium. E: Image demonstrating fault surface reflectivity. Reflection of vegetation along the top edge and above the one-euro coin. F: Grey, weathered fault plane showing a strong alignment of light-grey host-rock clasts parallel to slip direction (oneeuro coin for scale, bottom edge).

\subsubsection{Slip surface microstructures}

SEM analyses of the Arkitsa and Schinos slip surfaces reveal a low surface roughness at the microscale. The surfaces are well polished and, in some places, preserve parts of the hanging wall (Fig. 3A and F). Microgrooves are aligned parallel to the slip direction (Fig. 3B), and holes with a diameter of $6-8 \mu \mathrm{m}$ pierce the slip 
surfaces (Fig. 3A and D). The average surface roughness measured by AFM is 63.5 $\mathrm{nm}$ for the Arkitsa fault surface and $32.3 \mathrm{~nm}$ for the Schinos fault, respectively (see SF1 in the supplementary material). Localized erosion of the Arkitsa slip surface exposes the underlying fault rock, with a grain size of $2-5 \mu \mathrm{m}$ (Fig. 3A, B and C). The first 10-20 $\mu \mathrm{m}$ of the fault rock below the Arkitsa slip surface consist of a finegrained deformation product, which is situated on top of a comparatively coarsegrained, less deformed material (Fig. 3B and C).

In contrast, the Schinos fault surface consists of large, truncated grains with boundaries that meet in triple junctions (Fig. 3D and inset). A fragmented layer lies on top of undeformed calcite crystals (Fig. 3E), and the damage extends about 10-20 $\mu \mathrm{m}$ into the fault rock. Here also an amorphous material is present on the slip plane (Fig. 3E and F). On both faults, Arkitsa and Schinos, the amorphous material has a low contrast in backscattered-electron images (Fig $4 \mathrm{~A}$ and B). The phase also coats grain edges and reduces the slip surface roughness (Fig. 3C, E and F). In addition, the amorphous material infiltrates interstitial regions of the hanging-wall breccia and holds residual pieces of hanging wall in place (Fig. 3F).

Figure 4 presents Raman spectra from the amorphous material. Two broad peaks between 1200-1700 $\mathrm{cm}^{-1}$ indicate the presence of a disordered carbon phase, whilst a peak at $1086 \mathrm{~cm}^{-1}$ demonstrates the presence of crystalline calcite. The fitted spectrum from the Arkitsa fault plane gives a $\frac{I(D)}{I(G)}$ ratio of 0.543 at a D-peak position of $1339 \mathrm{~cm}^{-1}$ and a G-peak position of $1584 \mathrm{~cm}^{-1}$. The fitted spectrum from the Schinos fault plane gives a $\frac{I(D)}{I(G)}$ ratio of 0.789 at a D-peak position of $1344 \mathrm{~cm}^{-1}$ and a $G$ peak position of $1587 \mathrm{~cm}^{-1}$. 


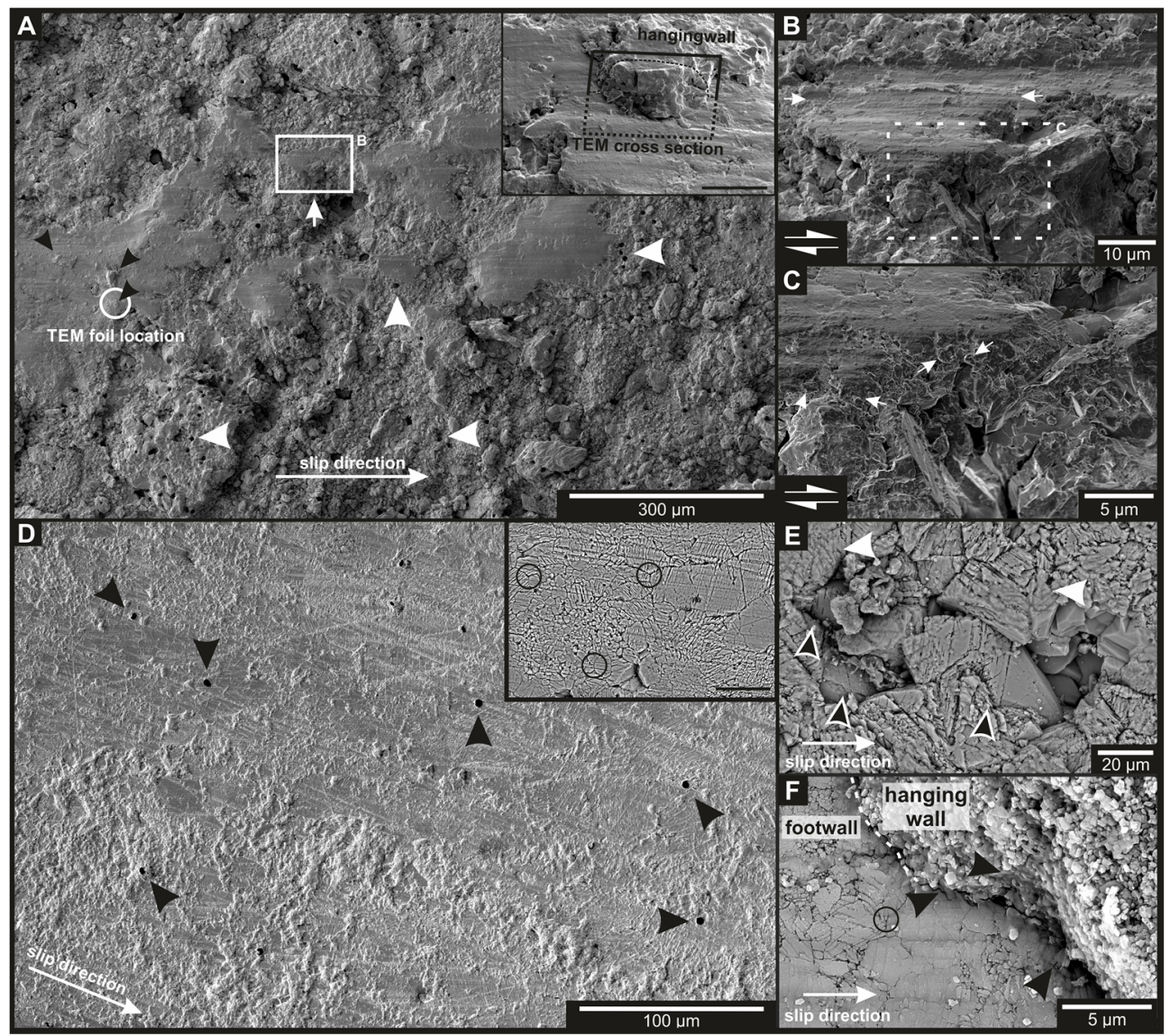

Figure 3: Representative slip surface microstructures of the Arkitsa $(A-C)$ and Schinos $(D-F)$ exposures. A: Secondary-electron overview image of the Arkitsa slip surface. Smooth slip patches with microgrooves parallel to slip direction. Uniform holes (white arrows) penetrate the slip surface. Residue of hanging wall on top of the slip surface patch (black arrows, white circle) with TEM sample location. Inset: Detailed view of TEM foil location from figure $5 A$, white circle. Scale bar $=5 \mu \mathrm{m}$. $\underline{B}$ : Close-up of slip surface from A. Fine-grained slip surface material situated on top of coarse fault rock grains. Microscope stage tilted to $52^{\circ}$. $\underline{C}$ : Close-up of section from B. Amorphous material covers roundish grains (black arrows). D: Secondary-electron image of Schinos slip surface with microgrooves parallel to slip direction. Uniform holes penetrate the principal slip surface (black arrows). Inset: Backscatter electron image illustrating triple junction grain boundary contacts. Scale bar $=50 \mu \mathrm{m}$. E: Backscatter electron image top view onto the slip surface. Cracks in idiomorphic calcite crystals are visible a few micrometres into the crystal (black-white arrows). Amorphous material with low backscatter contrast covers parts of the slip surface and reduces surface roughness (white, dashed lasso) $\mathbf{F}$ : Backscatter electron image of the contact between footwall and hanging wall (dashed line). Black arrows indicate the locations of an amorphous material with lower backscatter contrast. Black circle shows grain boundary triple junction. 


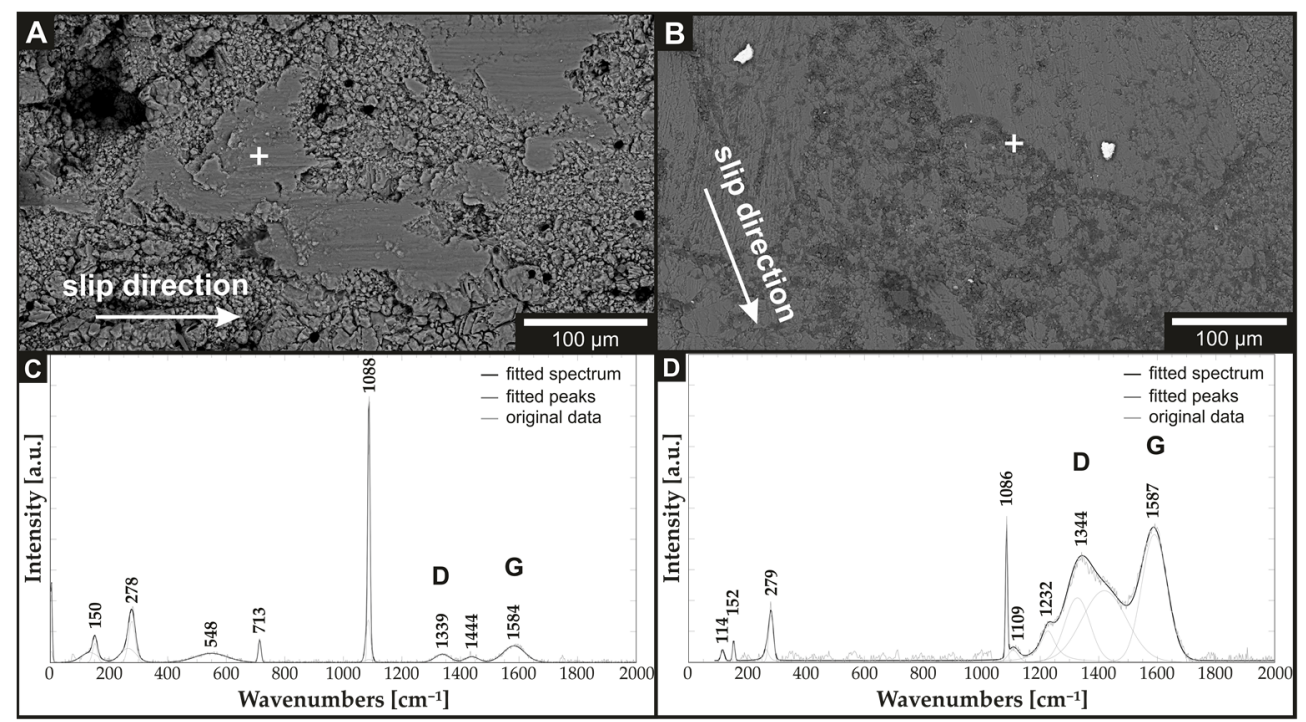

Figure 4: Backscatter electron images with locations of Raman spectroscopy measurements for Arkitsa $(A$ and $C)$ and Schinos (B and D) slip surfaces. $A$ and B: Backscatter electron images of the fault surfaces. A phase with low backscatter contrast (darker grey) is visible in B. C and D: Raman spectra showing the $D$ and $G$ peak position of a disordered carbon phase.

\subsubsection{Nanostructures}

TEM analyses on FIB-SEM foils of both fault-surface exposures reveal a thin surface coating (e.g., Fig. 8A and F, but also Fig. 6A-D). The uppermost layer of both fault-rock exposures is defined by a principal slip surface with a thin, non-crystalline coating between hanging wall and footwall (Fig. 5A and B, Fig. 6A-D). The coating exhibits homogenous diffraction contrast, shows no lattice fringes (Fig. 6A to D, 8A and F) and EDX analyses indicate the presence of carbon (C), iron (Fe), silicon ( $\mathrm{Si}$ ) and aluminium (Al) (Fig. 7, Si content of Arkitsa $~ 40$ area \% estimated with ImageJ). A similar content of impurity elements has been mentioned by Pluymakers and Røyne (2017), Collettini et al. (2013) and Goldberg et al. (2016). The coating connects hanging-wall breccia with the footwall fault surface (Fig. 6B and D) but also extends into the hanging-wall breccia (Fig. 6A and C). EELS measurements of the amorphous material are given in the inset of Fig. 6D. The onset of the $\pi^{*}$ peak represents the measured carbon K-edge at $284 \mathrm{eV}$, which is followed by a 'whaleback-shaped' $\sigma^{*}$ region. In addition, the measurement of the Schinos sample exhibits an additional peak at $286.5 \mathrm{eV}$, possibly indicating $\mathrm{C}-\mathrm{O}$ bonding. 

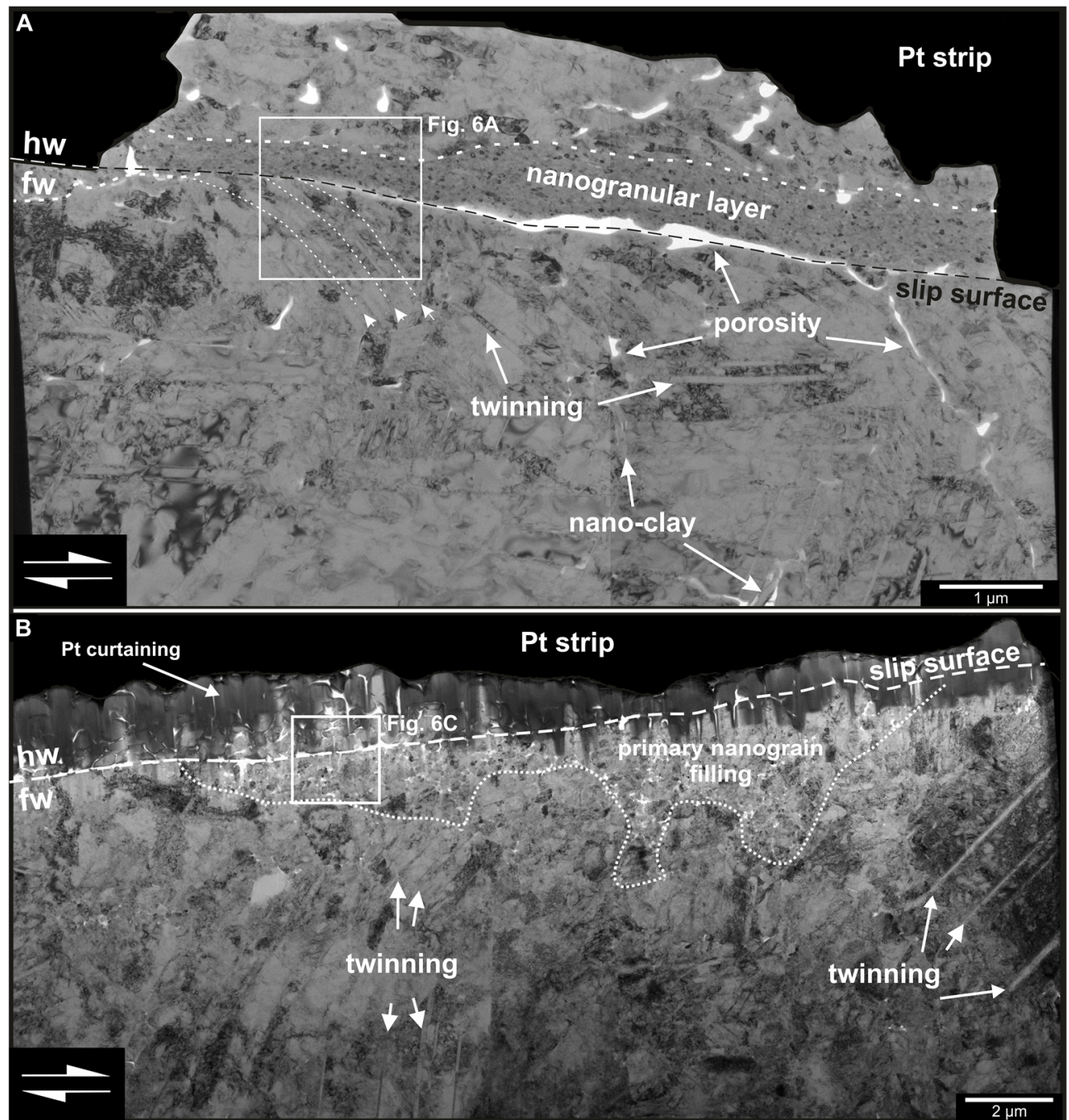

Figure 5: Overview of TEM cross sections into the principal slip surfaces of Arkitsa and Schinos, including preserved hanging-wall residue. A: Bright-field TEM image overview of representative Arkitsa nanostructures. The hanging-wall breccia consists of small, elongated calcite fragments held in place by non-crystalline carbon. The nanogranular layer is part of the hanging-wall breccia and lies on top of deformed calcite crystals. Fractures (dashed lines) bend down from the principal slip surface into the deformed calcite crystals. Fractures and holes form porosity inside the mirror slip volume and are filled either with non-crystalline carbon and/or nano-clay (see arrows with labelling). B: Bright-field TEM image with representative Schinos nanostructural hanging-wall to footwall relation. The hanging wall consists of small grains of several hundred nanometres. Individual grains are surrounded by noncrystalline carbon. The footwall hosts a discontinuous, primary nanograin filling. The grain size increases abruptly with distance from the slip surface to grains of several micrometres in size. Larger grains contain twins. hw = hanging wall, $f w=$ footwall . 
We observe a direct relation between the spatial distribution of amorphous material and calcite nanograins. For the Arkitsa fault exposure, a nanogranular layer is present with rounded, elliptical calcite nanograins of $\sim 50 \mathrm{~nm}$ size between the footwall and the hanging-wall breccia (Fig. 5A, 6A, B and 7). Selected area electron diffraction (SAED) patterns of the Arkitsa nanogranular layer in Figure 5A demonstrate the polycrystalline nature of the material with clustered diffraction spots forming two arcs subtending an angle of about $75^{\circ}$ (inset Fig. 6A). Figure 8A reveals that the thickness of the coating varies along the slip surface and locally incorporates calcite grains from the underlying nanostructure. We find that calcite nanograins are not restricted to the principal slip surface but also occur away from the displacement zone inside the fault rock (Fig. 8B). The nanograins do not contain any dislocations (Fig. 6B and $8 \mathrm{~B}$ ) and are not always in grain-to-grain contact in the plane of the section. Calcite nanograins of the Schinos exposure are mostly located between large grains along the principal slip surface (Fig. 8C and D). The gaps between large grains also contain an amorphous material that increases the overall smoothness of the fault surface. Inside the amorphous material, most nanograins have elongate shapes with no dislocation substructure (Fig. 8D). Nano-clay minerals often wrap around the calcite nanograins (Fig. 8D). 

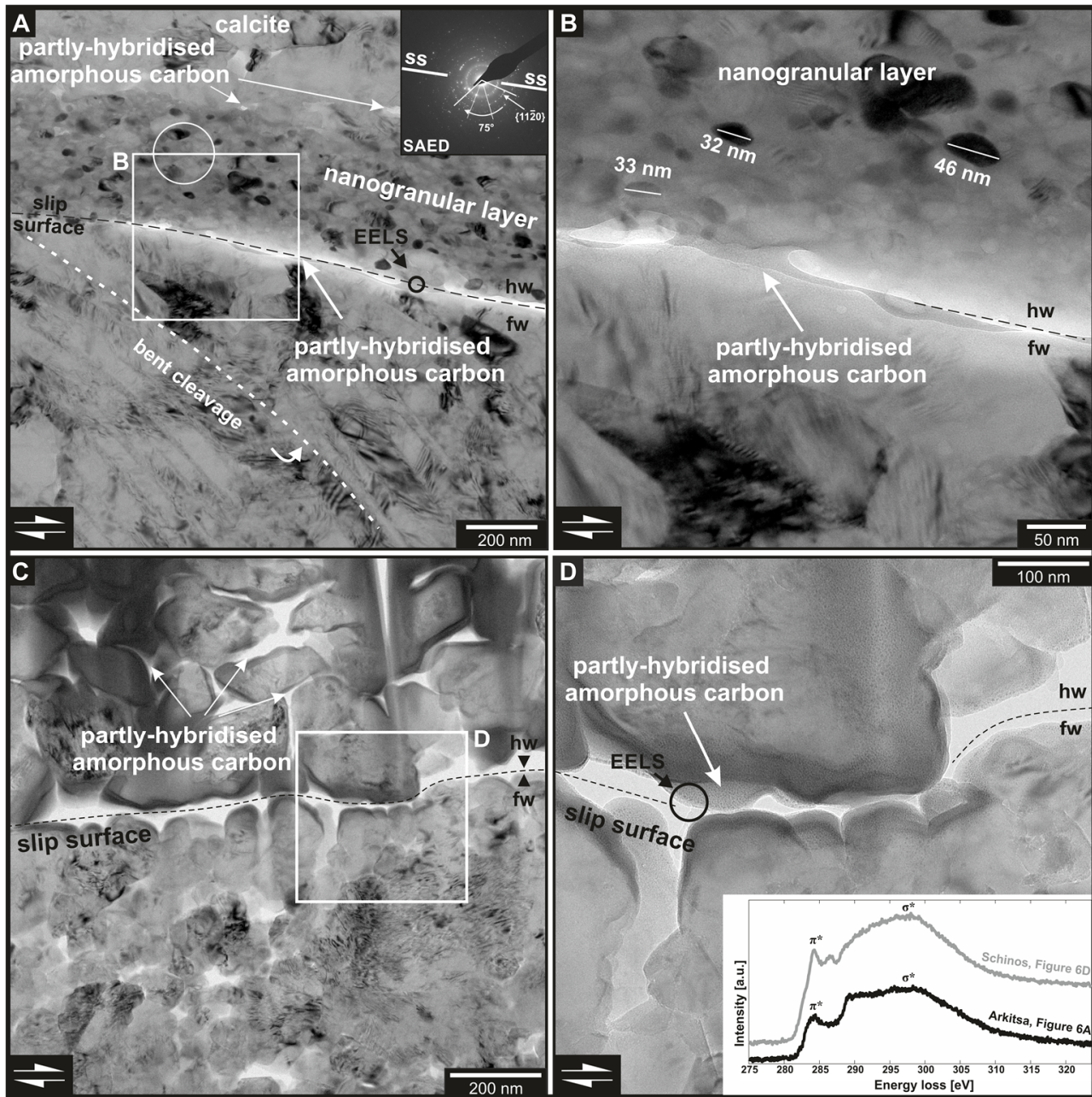

Figure 6: TEM cross sections illustrating the relationship between hanging-wall (hw) breccia and footwall (fw) contact for Arkitsa $(A-B)$ and Schinos $(C-D)$. A: TEM bright-field close-up from Fig. 5 A. Non-crystalline carbon establishes the contact between hanging wall and footwall. The footwall consists of large, stressed calcite crystals with bent fractures. Nanogranular layer with non-crystalline carbon and calcite nanograins. White circle indicates SAED location (circle diameter = effective aperture diameter); black circle depicts EELS measurement (circle diameter = aperture diameter). Inset: SAED showing two sets of crystal orientation. sS = slip surface. B: TEM bright-field close-up from A. Non-crystalline carbon connects hanging wall and footwall. The nanogranular layer produces Moiré fringes indicative of overlapping crystal lattices. Nanograins are not always in grain-to-grain contact. C: TEM bright-field close-up image from Fig. 5B. The grain size of the hanging wall is $200 \mathrm{~nm}$ and larger. The grain size of the footwall directly at slip surface is about $100 \mathrm{~nm}$. D: TEM bright-field close-up image from C. The hanging wall and footwall are connected via non-crystalline carbon. Black circle depicts EELS measurement (circle diameter = effective aperture diameter). Inset shows EELS spectra from black circles in A and D. 


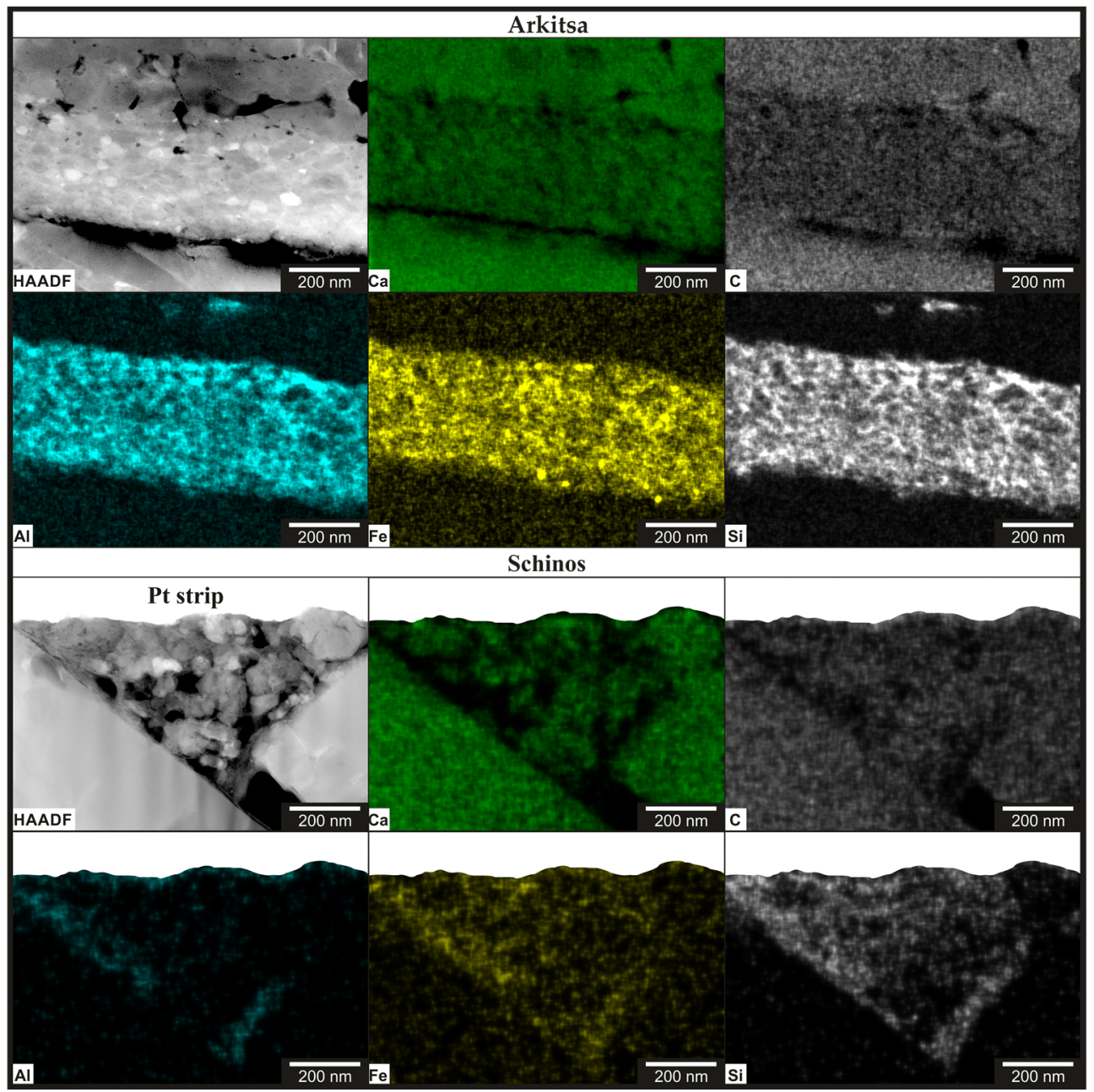

Figure 7: TEM-EDX maps of calcite nanogranular layer from Fig. 5A (Arkitsa) and surface filling Fig. 8C (Schinos) visualizing the element distribution. Overlap of calcium $(\mathrm{Ca})$ and carbon $(C)$ distribution confirms that the grains inside are calcite. Aluminium ( $\mathrm{Al}$ ), iron ( $\mathrm{Fe}$ ) and silicon (Si) are concentrated in the interstitial region around the calcite grains.

Further TEM investigation of the slip surfaces reveals a variety of slipderived deformation nanostructures. Neither fault exposure exhibits a gradual decrease in grain size towards the slip surface, but both show an abrupt change, instead. Adjacent to the principal slip surface, we observe twinned calcite crystals about $2-5 \mu \mathrm{m}$ in size (Fig. 5A and B). Dislocations are homogeneously distributed in the larger crystals from the Arkitsa exposure (Fig. 5A). For the Schinos case, the dislocation distribution appears to be less ordered, with dislocations concentrated towards grain contacts in slip direction (Fig. 8C). Bent cleavage fractures dip down from the Arkitsa slip surface and exhibit minor displacements together with slight 
increases in dislocation density along fracture planes (Fig. 5A and 6A). Along the slip surface, the nanostructure of the Arkitsa fault varies in intensity and develops a foam nanostructure (Fig. 8A). The layer thickness of the foam nanostructure is about $1 \mu \mathrm{m}$ and the grain size ranges from 100-200 $\mathrm{nm}$ with the grain boundaries exhibiting triple junctions at $\sim 120^{\circ}$ angles (Fig. 8A). This nanostructure is not observed in the samples analysed from the Schinos exposure, which instead contain dislocation arrays (Fig. 8C and E). In general, the foam nanostructure at Arkitsa appears to be less developed adjacent to the slip surface, especially where the fracture density is highest.

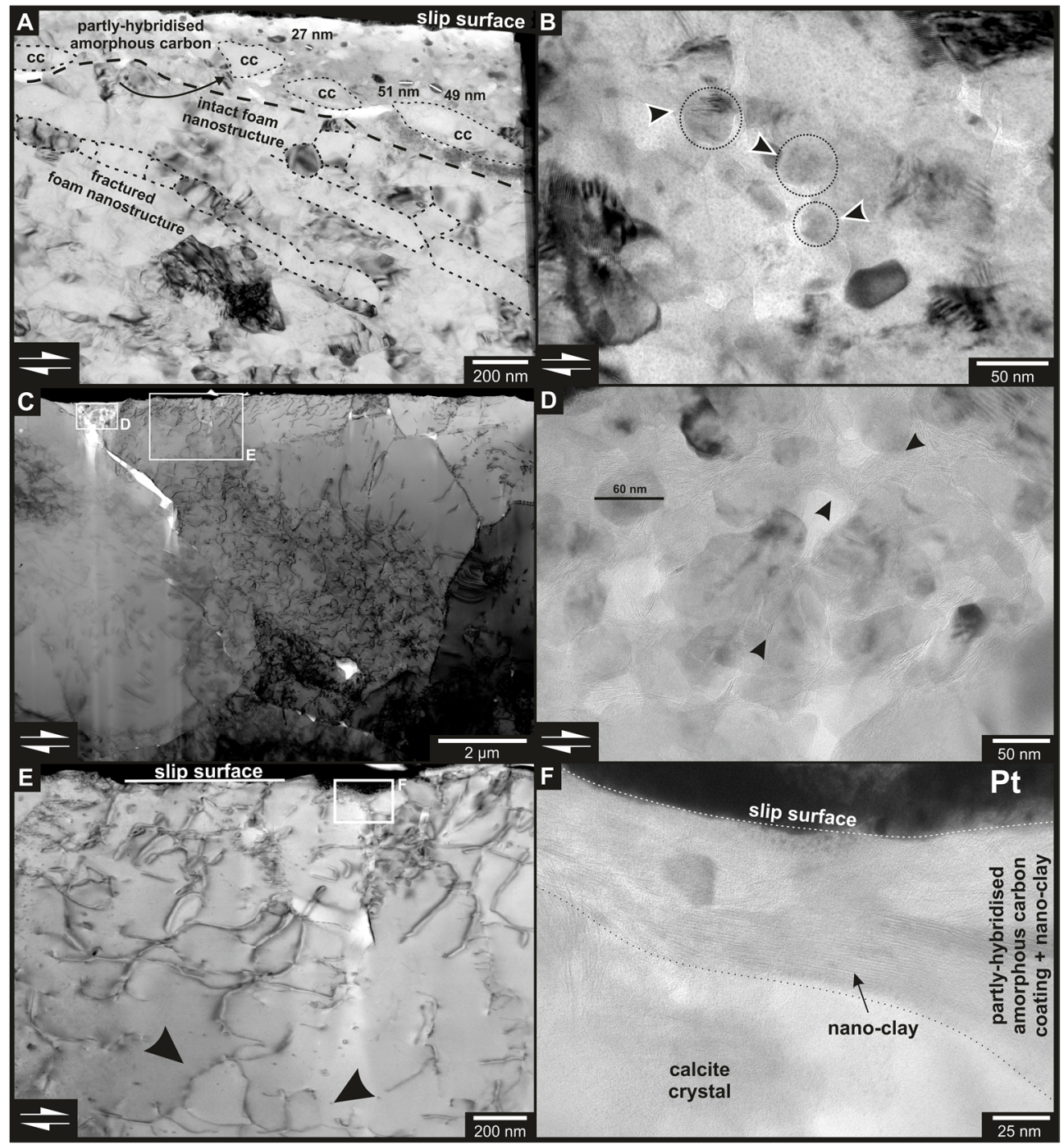


Figure 8: (previous page) Nanostructures of fault surface coating and nanograin abundance not associated with the principal slip surface. A: Bright-field TEM image from the Arkitsa exposure. Amorphous slip surface coating with calcite nanograins and crystal fragments from underlying foam nanostructure (black arrow). A sharp contact separates the underlying nanostructure from the slip surface coating. Nanostructure with former fracture planes (dashed lines), which originate from the principal slip surface, and overprint the existing nanostructure. B: Calcite nanograins away from the principal slip surface hosted inside non-crystalline carbon. Tip direction of black-white arrows indicate lattice fringe orientation of new grains. C: Bright-field STEM image overview. Large grains (5 $\mu \mathrm{m})$ with a heterogeneous dislocation density distribution. D: Calcite nanograins in non-crystalline carbon as a filling between two grain boundaries directly at the principal slip surface. Clay minerals wrap around the nanograins (black arrows). E: Bright-field STEM close-up from C showing the dislocation structure directly at the principal slip surface. Black arrows point to frozen dislocation loops. F: Bright-field TEM image from the Schinos exposure. Amorphous slip surface coating mixed with nano-clay on top of calcite crystal. $c c=$ calcite .

\subsection{Discussion}

\subsubsection{Processes revealed by nano/microstructures}

\subsubsection{Decarbonation and carbon reduction}

Nanostructural investigation of the Arkitsa and Schinos fault exposures reveal the importance of calcite decarbonation products for the formation of a smooth fault surface. TEM images reveal a coating of an amorphous material. We suggest that the amorphous material formed following calcite decarbonation, as a result of shear heating at asperity contacts or alternatively, the 'severe' introduction of dislocations during fault slip. In our natural samples, holes piercing the principal slip surface (Fig. $3 \mathrm{~A}$ and $\mathrm{D}$ ) indicate $\mathrm{CO}_{2}$ degassing as a product of the decarbonation reaction

$$
\mathrm{CaCO}_{3(\mathrm{~s})} \rightleftarrows \mathrm{CO}_{2(\mathrm{~g})}+\mathrm{CaO}_{(\mathrm{s})} \quad\left(\Delta H_{298 \mathrm{~K}}^{0_{2}}=+178 \mathrm{~kJ} \mathrm{~mol}^{-1}\right)(1)
$$

reported to occur due to thermal decomposition of calcite starting at $600{ }^{\circ} \mathrm{C}$ (Rodriguez-Navarro et al., 2009). However, experiments by Martinelli and Plescia (2004) recorded $\mathrm{CO}_{2}$ emission during ball milling experiments of calcite without increasing the macroscopic temperature. In addition to the $\mathrm{CO}_{2}$ emissions, the authors detected the presence of amorphous lime $(\mathrm{CaO})$ in their milling product as a result of a process termed 'mechanical liming'. Subsequent heating of the milling product resulted in a decrease of amorphous lime and the formation of calcite. The heating of the milling product carbonates the lime with atmospheric $\mathrm{CO}_{2}$ after overcoming the activation energy of reaction (1), leading to the formation of new calcite. The experiments of Martinelli and Plescia (2004) demonstrate that reaction (1) can also take place just by deforming calcite without reaching macroscopic temperatures $>600{ }^{\circ} \mathrm{C}$, although the temperature at asperity contacts could be higher. Mechanical liming may be important for wet deformation conditions where 
fluids are present and will buffer the temperature increase until all fluid of the system transforms into vapor. The buffering of temperature during deformation is in agreement with observations by Demurtas et al. (2019), where temperatures of < $200{ }^{\circ} \mathrm{C}$ were recorded during water-damped experiments at seismic velocities. In contrast, the same study records temperatures of $>600{ }^{\circ} \mathrm{C}$ for experiments at room humidity. We suggest that decarbonation can occur at macroscopic temperatures < $600{ }^{\circ} \mathrm{C}$ by mechanical liming, even under wet conditions, leading to the formation of lime and $\mathrm{CO}_{2}$.

The acquired electron energy loss and Raman spectra indicate the presence of a carbon phase. Hence, the presence of this phase implies the occurrence of carbon-reducing processes because reaction (1) does not produce elemental carbon. Precipitation of carbon in deformation experiments of Oohashi et al. (2014) under a hydrogen atmosphere suggests that the reaction

$$
\mathrm{CO}_{2(\mathrm{~g})}+2 \mathrm{H}_{2(\mathrm{~g})} \rightarrow \mathrm{C}_{(\mathrm{s})}+2 \mathrm{H}_{2} \mathrm{O}_{(\mathrm{g})} \quad\left(\Delta H^{0}{ }_{298 \mathrm{~K}}=-90 \mathrm{~kJ} \mathrm{~mol}^{-1}\right)
$$

can reduce $\mathrm{CO}_{2}$ to form carbon. Similarly, Spagnuolo et al. (2015) detected $\mathrm{H}_{2}(\mathrm{~g})$ and $\mathrm{CO}_{2(\mathrm{~g})}$ degassing during their experiments. Although reaction (2) is expressed as a chemical vapour deposition reaction, some of the hydrogen produced can go into solution to reduce dissolved $\mathrm{CO}_{2}$. This process is known to occur in hydrothermal systems where dissolved hydrogen can interact with $\mathrm{CO}_{2(\mathrm{aq})}$ to form reduced carbon phases (e.g., Milesi et al., 2015). Under wet conditions, the $\mathrm{CO}_{2}$ from reaction (1) goes into solution starting the hydrolysis reaction

$$
\begin{aligned}
\mathrm{CO}_{2(\mathrm{~g})} \rightleftarrows \mathrm{CO}_{2(\mathrm{aq})}+\mathrm{H}_{2} \mathrm{O} & \rightleftarrows \mathrm{H}_{2} \mathrm{CO}_{3} \\
& \rightleftarrows \mathrm{HCO}_{3}^{-}+\mathrm{H}^{+} \\
& \rightleftarrows \mathrm{CO}_{3}^{2-}+2 \mathrm{H}^{+}
\end{aligned}
$$

to give carbonic acid, hydrogen carbonate, carbonate ions, and protons (Ruiz-Agudo et al., 2013). The mole fraction solubility $\left(X_{1}\right)$ of $\mathrm{CO}_{2}$ in water at room temperature is, with $X_{1}=6.15 \times 10^{-4}$, one order of magnitude larger than $\mathrm{H}_{2}$ with $X_{1}=1.411 \times 10^{-5}$ (Gevantman, 2000). It is, therefore, more likely that a larger amount of $\mathrm{CO}_{2}$ will dissolve in water and form carbonic acid, being the more probable proton donor, for reducing carbon from the residual $\mathrm{CO}_{2}$. As an alternative, $\mathrm{CaO}$ surfaces can act as potential catalytic sites and promote the reaction with $\mathrm{H}_{2} \mathrm{O}$ at kinks, corners and/or steps. These surfaces can split $\mathrm{H}_{2} \mathrm{O}$ leading to one hydroxyl ion $(\mathrm{OH}-)$ and one proton $\left(\mathrm{H}^{+}\right)$which in turn may also be able to reduce carbon from $\mathrm{CO}_{2}$ (Kudłacz and Rodriguez-Navarro, 2014). The main requirement for this reaction to occur is the presence of crystalline $\mathrm{CaO}$. This would either require prior crystallisation of the 
suspected amorphous lime from reaction (1) or the lime resulting from reaction (1) was already crystalline. Calcium ions $\left(\mathrm{Ca}^{2+}\right)$ decrease the $\mathrm{pH}$ of the water facilitating $\mathrm{CO}_{2}$ solubility. Earth-alkali metal reactions with water are commonly known to produce hydrogen by reaction of the metal with water to form $\mathrm{H}_{2}$ and the corresponding metal hydroxide. As the reduction of $\mathrm{CO}_{2}$ by hydrogen does not require the participation of an additional reducing agent, it is likely to occur also under closed-system experimental conditions. With a variety of possible production reactions, it remains challenging to identify the main reaction responsible for the source of hydrogen for $\mathrm{CO}_{2}$ reduction. However, a combination of several processes is likely, with the simplest being the hydrolysis of $\mathrm{CO}_{2}$ in $\mathrm{H}_{2} \mathrm{O}$. The $\mathrm{CaO}$ or $\mathrm{Ca}^{2+}$ interaction with water can increase the $\mathrm{pH}$ up to 12.4 , as shown in experiments by Ruiz-Agudo et al. (2013), which increases the solubility of $\mathrm{CO}_{2}$ in water and would facilitate reaction (3). In general, the result would be the precipitation of carbon from the fluid, which would not be restricted to the principal slip surface but would also occur within existing porosity away from the slip surface.

\subsubsection{Carbon-bond $s p^{2}$ hybridisation}

The obtained $\frac{I(D)}{I(G)}$ ratios from Raman spectroscopy indicate that the slip surfaces are coated with nanocrystalline graphite according to the interpretation of the Raman modes by Ferrari and Robertson (2000). With the obtained $\frac{I(D)}{I(G)}$ ratios we can calculate the size of the nanocrystallites according to the equation from Pimenta et al. (2007)

$$
L_{a}=\frac{560}{E_{\text {laser }}^{4}}\left(\frac{I(D)}{I(G)}\right)^{-1}
$$

where $L_{a}$ is the cluster/crystallite size in nm, $E_{\text {laser }}$ is the energy (wavelength) of the laser with $2.33 \mathrm{eV}(532 \mathrm{~nm})$, and $\frac{I(D)}{I(G)}$ the intensity ratio of $\mathrm{D}$ and $\mathrm{G}$ peaks. Equation (4) is based on results from Pimenta et al. (2007), which revealed an inversely proportional relationship between the fourth power of $E_{\text {laser }}$ and the $\frac{I(D)}{I(G)}$ ratio. For the Arkitsa exposure we calculate a size of $L_{a}=35 \mathrm{~nm}\left(\frac{I(D)}{I(G)}=0.543\right)$ and for the Schinos exposure $L a=24 \mathrm{~nm}\left(\frac{I(D)}{I(G)}=0.789\right)$. While Pimenta et al. (2007) calculate with $L_{a}$ the graphite nanocrystallite size, Ferrari and Robertson (2000) mention $L a$ as the cluster diameter of carbon aromatic rings. The terminology used by Ferrari and Robertson (2000) for nanocrystalline graphite and amorphous carbon is based on the starting 
material experiencing disorder. When disordering graphite, $\frac{I(D)}{I(G)}$ will increase with increasing disorder and development of a D peak. With amorphous carbon as the starting material, the development of a D peak and the increase in $\frac{I(D)}{I(G)}$ indicates clustering. Because the D peak arises from aromatic rings, for small La the D-mode strength is proportional to the cluster area or diameter (Ferrari and Robertson, 2000).

According to our discussion of possible options for carbon reduction in Section 1.5.1.1, where the majority of carbon is most likely produced as the outcome of post-seismic, chemical reduction processes, the initially precipitated carbon may be amorphous. Nathan et al. (1974) reported for glass-like carbon a D-peak position at $1340 \mathrm{~cm}^{-1}$ and a G-peak position at $1590 \mathrm{~cm}^{-1}$, while Wang et al. (1990) reported a D-peak position at $1347 \mathrm{~cm}^{-1}$ and a G-peak position at $1588 \mathrm{~cm}^{-1}$. The band positions from Wang et al. (1990) were obtained with a $515 \mathrm{~nm}$ laser on glass-like carbon, which was heat treated at $2000{ }^{\circ} \mathrm{C}$. Wang et al. (1990) also noted that the D-peak position is sensitive to the wavelength of the laser used, exhibiting a band-position shift towards lower wavenumbers with increasing laser wavelength. The reported values from Nathan et al. (1974) and Wang et al. (1990) are in agreement with our measured band positions for Arkitsa (D peak: $1339 \mathrm{~cm}^{-1}, \mathrm{G}$ peak: $1584 \mathrm{~cm}^{-1}$ ) and Schinos (D peak: $1344 \mathrm{~cm}^{-1}, \mathrm{G}$ peak: $1587 \mathrm{~cm}^{-1}$ ), suggesting that the slip surface coating resembles glass-like carbon. Therefore, instead of the development of nanocrystalline graphite, our results are consistent with the presence of a partlyordered carbon species exhibiting an electron-bond environment akin to glass-like carbon. The different electron-bond structure may be evidence for the beginning of a clustering process of the aromatic carbon rings ( $\mathrm{sp}^{2}$-clustering), which is likely to have occurred during post-seismic annealing.

High-resolution TEM imaging coupled with electron diffraction suggests that the surface coating is non-crystalline. This interpretation is supported by our EELS analysis, which results in spectra resembling amorphous carbon (Fig. 9). However, although both spectra have a $\pi^{*}$ peak, the phase identified here has a more pronounced $\sigma^{*}$ region indicating a stronger graphitic order, yet lacking full longrange order as observed in crystalline graphite (Rosenberg et al., 1986). Our spectra resemble those of Stroud et al. (2011), suggested to be indicative of glass-like carbon with $\mathrm{sp}^{2}$ hybridisation. In addition, heat treatment experiments on non-graphitising carbons by Zhang et al. (2011) produce similar EEL spectra when annealing the initially amorphous material at $600-800{ }^{\circ} \mathrm{C}$. Although the EEL spectra resemble the 
glass-like carbon phase by Stroud et al. (2011), we will refer to the carbon phase from the fault exposures as partly-hybridised amorphous carbon (PHAC). Impurities of $\mathrm{Al}, \mathrm{Fe}$, and Si (Fig. 7) in the PHAC suggest either the concomitant decomposition of silicate phases (e.g., clays) during slip or the influence of hydrothermal fluids percolating along the fault zone, precipitating clay. We suggest that the presence of PHAC demonstrates that amorphous carbon is precipitated during or immediately after slip but undergoes ordering ( $\mathrm{sp}^{2}$-hybridisation) via post-seismic annealing, as demonstrated by Raman spectroscopy and EELS.

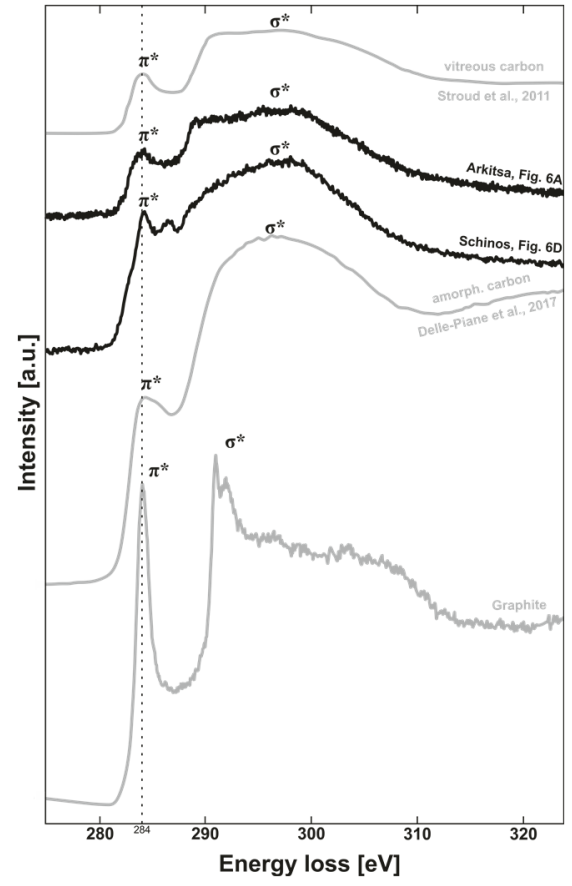

Figure 9: Comparison of electron energy loss spectra. Calcite decomposition products presented here have a small intensity difference of $\pi^{*}$ to $\sigma^{*}$ peak. The EEL spectrum from vitreous (glass-like) carbon (Stroud et al., 2011) exhibits a similar $\sigma^{*}$ peak shape compared to the acquired spectra of this study. Reference spectrum of graphite has three weak $\sigma^{*}$ peak features which are absent in all other carbon spectra.

\subsubsection{Secondary nanograin nucleation}

Our nanostructural investigations reveal a close spatial relationship between PHAC and newly formed calcite nanograins (e.g., Fig. 6A). Nucleation of nanograins inside the decomposition product implies a similar chemistry of reactant and product. As discussed in Section 5.1.1, reaction (1) also produces lime, which is highly reactive and can form portlandite $\left(\mathrm{Ca}\left(\mathrm{OH}_{2}\right)\right)$ under hydrous conditions via the hydration reaction

$$
\mathrm{CaO}_{(\mathrm{s})}+\mathrm{H}_{2} \mathrm{O} \rightarrow \mathrm{Ca}(\mathrm{OH})_{2(\mathrm{~s})} \quad\left(\Delta H^{0_{298 K}}=-65 \mathrm{~kJ} \mathrm{~mol}^{-1}\right)(5)
$$

In the presence of $\mathrm{CO}_{2}$, portlandite back-reacts to calcite and water by the carbonation reaction: 


$$
\mathrm{Ca}(\mathrm{OH})_{2}+\mathrm{CO}_{2} \rightleftarrows \mathrm{CaCO}_{3}+\mathrm{H}_{2} \mathrm{O}\left(\Delta H^{0_{298 K}}=-93 \mathrm{~kJ} \mathrm{~mol}^{-1}\right)
$$

Kudłacz and Rodriguez-Navarro (2014) observed a nucleation-related crystallographic preferred orientation in two sets of portlandite crystals. The angle between the $\{11 \overline{2} 0\}_{\text {portlandite }}$ planes was $75^{\circ}$, implying that portlandite developed with a topotactic relationship of the $\{11 \overline{2} 0\}_{\text {portlandite }}$ planes parallel to the $\{110\}_{\mathrm{CaO}}$ planes of lime. The SAED inset of Fig. 6A indicates two preferred orientations with an angle of about $75^{\circ}$ (centre to centre) between the $\{11 \overline{2} 0\}$ planes of calcite in our natural samples, supporting our described back-reaction steps from lime, through portlandite, to calcite. In addition, we also observe dislocation-free nanograins away from the slip surface (Fig. $8 \mathrm{~B}$ ). Hence, we suggest that the calcite nanograins of the nanogranular layer in figure $5 \mathrm{~A}, 6 \mathrm{~A}, \mathrm{~B}$ and $8 \mathrm{D}$ are not the outcome of grain-size reduction or plastic-deformation processes during slip. We propose that these nanograins are secondary and originate from pseudomorphic growth of calcite after portlandite and portlandite after lime from decarbonation.

\subsubsection{Fault surface evolution during the seismic cycle}

The onset of fault slip triggers a variety of inelastic deformation processes. Cleavage fractures in Figure 3E demonstrate that slip can localise within the first 20 $\mu \mathrm{m}$ inside the fault rock. The localisation shows that the transfer of strain from the slip surface is limited, because the cleavage fractures are concentrated close to the slip surface. Fractures cross-cut the foam nanostructure and produce a nanofabric where grains are trapped between sheet-like fracture planes (Fig 8A). Fracturing leads to grain-size reduction and produces the primary nanograins, which can fill in surface depressions (Fig. 5B). Shear heating may cause a considerable temperature rise along grain and asperity contacts. The temperature increase or grain fracturing (= mechanical liming) trigger the decarbonation reaction (Eq. 1), which leads to $\mathrm{CO}_{2}$ degassing and the production of lime.

During and immediately after fault slip, lime infiltrates cracks and cavities and reacts with the fluids to crystalline portlandite (Eq. 5). The resulting portlandite crystals back-react with the released $\mathrm{CO}_{2}$ to form secondary calcite nanograins (Eq. 6). During the pseudomorphic replacement of portlandite by calcite, the secondary calcite nanograins preserve the crystallographic nucleation relationship from portlandite. Nano-clay precipitates inside the reaction medium either from the fluid or from previously decomposed silicate minerals and may contribute to the fault mirror appearance. Reduction of carbon can occur by reducing $\mathrm{CO}_{2}$ with dissolved 
hydrogen (Eq. 2) either from the hydrolysis reaction (Eq. 3) or by water splitting with lime as a catalyst. Subsequent $\mathrm{sp}^{2}$-hybridisation of the amorphous carbon results in aromatic ring clustering and hence, in a stronger near-field bonding of the carbon. As a result, PHAC is formed.

Graphitisation of carbonaceous materials in active faults may be an important factor for fault reactivation because graphite is characterised by a low friction coefficient of $\mu_{\mathrm{ss}}=0.08$ (Oohashi et al., 2011). Glass-like carbon is a stable, non-graphitising type of carbon, which requires an activation energy of $+215 \mathrm{~kJ} \mathrm{~mol}-$ 1 to initiate graphitisation (Saxena and Bragg, 1978; Hokao et al., 2000). The high activation energy would imply that on natural faults graphite can only be found after a considerable energy input to induce graphitisation of glass-like carbon species or when amorphous carbon is initially produced. Kaneki and Hirono (2019) illustrate with their deformation experiments on carbonaceous materials (CMs) that CMs found in natural fault zones can respond differently to imposed deformation. In essence, $\mathrm{CMs}$ can decrease in maturity when starting with a mature $\mathrm{CM}$ and increase in maturity when deforming a low-maturity CM. Saxena and Bragg (1978) identified three temperature-dependent stages for graphitisation of glass-like carbon: (1) dehydrogenation at $<1500{ }^{\circ} \mathrm{C}$, (2) stress relief of the structure at $1500 \leq$ $2300{ }^{\circ} \mathrm{C}$, and (3) the onset of graphitisation at $>2300{ }^{\circ} \mathrm{C}$. A high-temperature treatment of synthetic glass-like carbon can cause graphitisation, suggesting a thermodynamic control of the graphitisation process.

Molecular dynamics simulations of $\mathrm{sp}^{2}$ carbon-bond self-assembly illustrate that sp2-clustering from amorphous precursors can commence after 200 picoseconds at $\sim 3200{ }^{\circ} \mathrm{C}$ (Powles et al., 2009). This short time span suggests that the $\mathrm{sp}^{2}$-clustering we observe here takes place immediately after carbon reduction. In addition, the simulations suggest that once $\mathrm{sp}^{2}$-bonded stable clusters form, breaking these bonds to further rearrange and increase $\mathrm{sp}^{2}$-ordering may require the need to overcome an additional energy barrier. This behaviour could explain why the PHAC observed here never reached a higher degree of graphitisation, because the energy input was not enough to break the initial, stable carbon clusters. Also, synthetic glass-like carbon displays the often described, entangled, lath-like structure (e.g., Saxena and Bragg, 1978). Although the PHAC observed here lacks the aforementioned nanostructure, it does have the vibrational and electronic properties of glass-like carbon (Fig. 4 C and D, Fig. 9). 
Because PHAC is formed by chemical precipitation and hybridisation, in contrast to pyrolysis synthesis of glass-like carbon (Powles et al., 2009), we propose that the way the carbon is formed influences the structure of the material while maintaining a similar interatomic bond structure. This suggestion is supported by Powles et al. (2009), who point out that the physical properties of glass-like carbon depend on the formation conditions, the precursor material, and on the annealing conditions. Further research is required to clarify whether the consideration of geological time scales for post-seismic annealing of PHAC at lower temperatures may yield a similar result in gradual graphitisation or whether fault reactivation might contribute to slightly increasing the PHAC maturity by imposing deformation as suggested by Kaneki and Hirono (2019).

\subsubsection{Advances in understanding fault surface evolution}

Amorphous carbon has been observed in deformation experiments (Verberne et al., 2014; Spagnuolo et al., 2015; Delle Piane et al., 2017) and its mechanical role has been assessed by Oohashi et al. (2011) and Kaneki and Hirono (2019). Oohashi et al. (2011) measured a friction coefficient for amorphous carbon of $\mu=0.54$ at the initiation of slip and a low steady-state friction coefficient of $\mu_{s s}=0.15$ at seismic slip velocities. Di Toro et al. (2011) speculated about fault lubrication by carbonate decomposition products, but the present study shows the extent of amorphous coatings. Decarbonation may be an important process for producing a thin fault surface coating and mainly responsible for the low surface roughness by smoothing out surface corrugations. Because the fault surfaces show little variation in the field, our results suggest that the fault planes of both fault exposures are at present covered with the decarbonation and carbon hybridisation products.

Our EEL and Raman spectroscopy results indicate that PHAC has a similar carbon-bonding environment compared to glass-like carbon. Synthetic glass-like carbon has an entangled lath-like structure consisting of ordered carbon sheets while the natural PHAC has no nanostructure. The mechanical properties of glass-like carbon, heat treated at $1000{ }^{\circ} \mathrm{C}$, show a Youngs modulus of $E=29 \mathrm{GPa}$ and a shear modulus of $G=12.5 \mathrm{GPa}$ (Robertson, 1991). Hokao et al. (2000) report a friction coefficient for glass-like carbon of $\mu=0.21$ and $\mu=0.13$ for mixtures of glass-like carbon with graphite. However, as the structure of the PHAC is different from synthetic glass-like carbon, we suggest that mechanical properties of the synthetic material may not fully reflect the mechanical behaviour of the carbon phase reported 
here. Because little is known about the deformation of various crystalline and noncrystalline carbon phases, further experimental investigations are warranted.

While previous research focused mainly on mechanisms of grain size reduction (Sammis and Ben-Zion, 2008; Siman-Tov et al., 2013), our results highlight the importance of decarbonation and back-reactions as part of the overall fault deformation and healing behaviour. In contrast to Siman-Tov et al. (2013), we do not observe small grains evolving from fracturing long, twin-derived beams of calcite. However, our results indicate that, for the natural carbonate faults studied here, a nanogranular coating is not the only feature producing a fault mirror surface, similar to results of Fondriest et al. (2013). For example, the Schinos fault exposure illustrates that MMSs can contain no coating of calcite nanograins (Fig. 7C, E and F). Instead, MSS are produced by the interplay of grain-size reduction, decarbonation, backreactions, and annealing. The present study does not exclude crystal-plastic or brittle deformation as an important grain-size reduction mechanism in fault gouges to form primary nanograins. Instead, we demonstrate that grain-size reduction alone may not be the governing mechanism to form a fault mirror surface. The formation of an amorphous phase with low viscosity during deformation could explain the low friction, stable, near-steady-state behaviour after the onset of weakening observed by Han et al. (2007a and 2007b), as well as the increase in friction coefficient via recarbonation and carbon hybridisation after displacement stopped (Spagnuolo et al., 2015). The chemical reactions revealed here suggest that a succession of healing reactions take place after fault slip ceases.

\subsection{Conclusions}

We conclude that decarbonation of calcite and the subsequent reaction of the decarbonation products produces fault mirror surfaces. The decarbonation process itself may be a major co-seismic fault weakening factor and, fault slip is facilitated on a decarbonation-product glide film. Frictional behaviour during slip may be dictated by lubrication of low viscosity (amorphous) calcium oxide and (amorphous) carbon. Occasional precipitation of clay inside the decarbonation products may contribute to decreasing surface roughness. Post-seismic hybridisation produces partly-hybridised amorphous carbon and connects footwall with hanging wall. Ultimately, post-seismic carbonation of portlandite produces new, secondary nano-sized calcite crystals $<50 \mathrm{~nm}$ by pseudomorphic replacement, and this carbonation facilitates fault healing. 


\section{Acknowledgements}

This study was funded by the Dutch research organisation (NWO) with the project number ALWOP.2015.082. We would like to thank the editor John Brodholt and three anonymous reviewers for constructive comments. The microstructural studies were conducted at EMU, the Utrecht University Facility for Electron Microscopy. The head of facility Dr M. A. van Huis, facility manager C.W.T.M. Schneijdenberg, and J. D. Meeldijk are thanked for support. Funding provided from the Utrecht University infrastructure fund is gratefully acknowledged. H.E. King is thanked for helping with Raman spectroscopy. The authors also thank A. Niemeijer for discussions and Ioannis Koukouvelas (University of Patras) for suggesting sampling outcrops along the Schinos fault.

\section{References}

Ambraseys N.N., Jackson J.A., 1990. Seismicity and associated strain of central Greece between 1890 and 1988. Geophysical Journal International 101, 663-708, DOI: 10.1111/j.1365-246X.1990.tb05577.x.

Bullock R. J., De Paola N., Holdsworth R. E., Trabucho-Alexandre J., 2014. Lithological controls on the deformation mechanisms operating within carbonate-hosted faults during the seismic cycle. Journal of Structural Geology. 58, 22-44. DOI: 10.1016/j.jsg.2013.10.008.

Collettini C., Viti C., Tesei T., Mollo S., 2013. Thermal decomposition along natural carbonate faults during earthquakes. Geology. 41, 927-930, DOI: 10.1130/G34421.1.

Collettini C., Carpenter B.M., Viti C., Cruciani F., Mollo S., Tesei T., Trippetta F., Valoroso L., Chiaraluce L., 2014. Fault structure and slip localization in carbonate-bearing normal faults: An example from the Northern Apennines of Italy. Journal of Structural Geology. 67, 154-166, DOI: 10.1016/j.jsg.2014.07.017.

Collier R.E., Pantosti D., D'addezio G., De Martini P.M., Masana E., Sakellariou D., 1998. Paleoseismicity of the 1981 Corinth earthquake fault: Seismic contribution to extensional strain in central Greece and implications for seismic hazard. Journal of Geophysical Research: Solid Earth. 103, B12. 30001-30019, DOI: 10.1029/98JB02643.

De Paola N., Hirose T., Mitchell T., Di Toro G., Viti C., Shimamoto T., 2011. Fault lubrication and earthquake propagation in thermally unstable rocks. Geology. 39, 35-38, DOI: 10.1130/G31398.1. 
De Paola N., Holdsworth R.E., Viti C., Collettini C., Bullock R., 2015. Can grain size sensitive flow lubricate faults during the initial stages of earthquake propagation? Earth and Planetary Science Letters. 431, 48-58, DOI: 10.1016/j.epsl.2015.09.002.

Delle Piane C., Piazolo S., Timms N.E., Luzin V., Saunders M., Bourdet J., Giwelli A., Ben Clennell M., Kong C., Rickard W.D., 2017. Generation of amorphous carbon and crystallographic texture during low-temperature subseismic slip in calcite fault gouge. Geology. 46, 163-166, DOI: 10.1130/G39584.1.

Demurtas M., Smith S.A., Prior D.J., Spagnuolo E., Di Toro G., 2019. Development of crystallographic preferred orientation during cataclasis in low-temperature carbonate fault gouge. Journal of Structural Geology. 126, 37-50, DOI: 10.1016/j.jsg.2019.04.015.

Di Toro G., Goldsby D.L., Tullis T.E., 2004. Friction falls towards zero in quartz rock as slip velocity approaches seismic rates. Nature. 427, 436, DOI: 10.1038/nature02249.

Di Toro G., Han R., Hirose T., De Paola N., Nielsen S., Mizoguchi K., Ferri F., Cocco M., Shimamoto T., 2011. Fault lubrication during earthquakes. Nature. 471, 494, DOI: $10.1038 /$ nature09838.

Ferrari A.C., Robertson J., 2000. Interpretation of Raman spectra of disordered and amorphous carbon. Physical review. B 61, 14095, DOI: 10.1103/PhysRevB.61.14095.

Fondriest M., Smith S.A., Candela T., Nielsen S.B., Mair K., Di Toro G., 2013. Mirrorlike faults and power dissipation during earthquakes. Geology. 41, 1175-1178, DOI: $10.1130 / G 34641.1$.

Ganas A., Sokos E., Agalos A., Leontakianakos G., Pavlides S., 2006. Coulomb stress triggering of earthquakes along the Atalanti Fault, central Greece: Two April 1894 M6 events and stress change patterns. Tectonophysics. 420, 357-369, DOI: 10.1016/j.tecto.2006.03.028.

Ganas A., Roberts G.P., Memou T., 1998. Segment boundaries, the 1894 ruptures and strain patterns along the Atalanti Fault, central Greece. Journal of Geodynamics. 26, 461-486, DOI: 10.1016/S0264-3707(97)00066-5.

Gevantman L., 2000. Solubility of selected gases in water. Nitric oxide (NO) 308.3.348, 10-4. 
Goldberg R., Siman-Tov S., Emmanuel S., 2016. Weathering resistance of carbonate fault mirrors promotes rupture localization. Geophysical Research Letters. 43, 3105-3111, DOI: 10.1002/2016GL067788.

Green H.W., Shi F., Bozhilov K., Xia G., Reches A.Z., 2015. Phase transformation and nanometric flow cause extreme weakening during fault slip. Nature Geoscience. 8, 484, DOI: 10.1038/ngeo2436.

Han R., Hirose T., Shimamoto T., 2010. Strong velocity weakening and powder lubrication of simulated carbonate faults at seismic slip rates. Journal of Geophysical Research: Solid Earth 115.B3, DOI: 10.1029/2008JB006136.

Han R., Shimamoto T., Hirose T., Ree J., Ando J., 2007a. Ultralow friction of carbonate faults caused by thermal decomposition. Science. 316, 878-881, DOI: 10.1126/science.1139763.

Han, R., Shimamoto, T., Ando, J., and Ree, J.-H., 2007b, Seismic slip record in carbonate-bearing fault zones: An insight from high-velocity friction experiments on siderite gouge: Geology. 35, 1131-1134, DOI:10.1130/G24106A.1.

Hirose T., Mizoguchi K., Shimamoto T., 2012. Wear processes in rocks at slow to high slip rates. Journal of Structural Geology. 38, 102-116, DOI: 10.1016/j.jsg.2011.12.007.

Hokao M., Hironaka S., Suda Y., Yamamoto Y., 2000. Friction and wear properties of graphite/glassy carbon composites. Wear. 237, 54-62, DOI: 10.1016/S00431648(99)00306-3.

Jackson J., McKenzie D., 1999. A hectare of fresh striations on the Arkitsa fault, central Greece. Journal of Structural Geology. 21, 1-6, DOI: 10.1016/S01918141(98)00091-1.

Johnson J.W., Oelkers E.H., Helgeson H.C., 1992. SUPCRT92: A software package for calculating the standard molal thermodynamic properties of minerals, gases, aqueous species, and reactions from 1 to 5000 bar and 0 to $1000{ }^{\circ} \mathrm{C}$. Computers \& Geosciences. 18, 899-947, DOI: 10.1016/0098-3004(92)90029-Q.

Jones R.R., Kokkalas S., McCaffrey K., 2009. Quantitative analysis and visualization of nonplanar fault surfaces using terrestrial laser scanning (LIDAR)-The Arkitsa fault, central Greece, as a case study. Geosphere. 5, 465-482, DOI: doi.org/10.1130/GES00216.1.

Kaneki S., Hirono T., 2019. Diagenetic and shear-induced transitions of frictional strength of carbon-bearing faults and their implications for earthquake rupture 
dynamics in subduction zones. Scientific reports. 9, 7884, DOI: 10.1038/s41598019-44307-y.

Kaplanis A., Koukouvelas I., Xypolias P., Kokkalas S., 2013. Kinematics and ophiolite obduction in the Gerania and Helicon Mountains, central Greece. Tectonophysics. 595, 215-234, DOI: 10.1016/j.tecto.2012.07.014.

Kirkpatrick J.D., Rowe C.D., White J.C., Brodsky E.E., 2013. Silica gel formation during fault slip: Evidence from the rock record. Geology. 41, 1015-1018, DOI: 10.1130/G34483.1.

Kokkalas S., Jones R.R., McCaffrey K., Clegg P., 2007. Quantitative fault analysis at Arkitsa, Central Greece, using terrestrial laser-scanning (LiDAR). Bulletin of the Geological Society of Greece. 37, 1-14.

Kudłacz K., Rodriguez-Navarro C., 2014. The mechanism of vapor phase hydration of calcium oxide: implications for $\mathrm{CO}_{2}$ capture. Environmental science \& technology. 48, 12411-12418, DOI: 10.1021/es5034662.

Martinelli G., Plescia P., 2004. Mechanochemical dissociation of calcium carbonate: laboratory data and relation to natural emissions of $\mathrm{CO}_{2}$. Physics of the Earth and Planetary Interiors. 142, 205-214, DOI: 10.1016/j.pepi.2003.12.009.

Milesi V., Guyot F., Brunet F., Richard L., Recham N., Benedetti M., Dairou J., Prinzhofer A., 2015. Formation of $\mathrm{CO}_{2}, \mathrm{H}_{2}$ and condensed carbon from siderite dissolution in the $200-300{ }^{\circ} \mathrm{C}$ range and at $50 \mathrm{MPa}$. Geochimica et Cosmochimica Acta. 154, 201-211, DOI: doi.org/10.1016/j.gca.2015.01.015.

Nathan M.I., Smith Jr J.E., Tu K.N., 1974. Raman spectra of glassy carbon. Journal of Applied Physics. 45, 2370, DOI: doi.org/10.1063/1.1663599.

Oohashi K., Hirose T., Shimamoto T., 2011. Shear-induced graphitization of carbonaceous materials during seismic fault motion: Experiments and possible implications for fault mechanics. Journal of Structural Geology. 33, 1122-1134, DOI: 10.1016/j.jsg.2011.01.007.

Oohashi K., Han R., Hirose T., Shimamoto T., Omura K., Matsuda T., 2014. Carbonforming reactions under a reducing atmosphere during seismic fault slip. Geology. 42, 787-790, DOI: 10.1130/G35703.1.

Pec M., Stünitz H., Heilbronner R., Drury M., de Capitani C., 2012. Origin of pseudotachylites in slow creep experiments. Earth and Planetary Science Letters. 355, 299-310, DOI: 10.1016/j.epsl.2012.09.004. 
Pimenta M.A., Dresselhaus G., Dresselhaus M.S., Cancado L.G., Jorio A., Saito R., 2007. Studying disorder in graphite-based systems by Raman spectroscopy. Physical chemistry chemical physics. 9, 1276-1290, DOI: 10.1039/B613962K.

Pluymakers A., Røyne A., 2017. Nanograin formation and reaction-induced fracturing due to decarbonation: Implications for the microstructures of fault mirrors. Earth and Planetary Science Letters. 476, 59-68, DOI: 10.1016/j.epsl.2017.08.001.

Powles R.C., Marks N.A., Lau D., 2009. Self-assembly of $s p^{2}$-bonded carbon nanostructures from amorphous precursors. Physical Review B. 79, 075430, DOI: 10.1103/PhysRevB.79.075430.

Roberts S., Jackson J., 1991. Active normal faulting in central Greece: an overview. Geological Society, London, Special Publications. 56, 125-142, DOI: 10.1144/GSL.SP.1991.056.01.09.

Robertson J., 1991. Hard amorphous (diamond-like) carbons. Progress in Solid State Chemistry. 21, 199-333, DOI: 10.1016/0079-6786(91)90002-H.

Rodriguez-Navarro C., Ruiz-Agudo E., Luque A., Rodriguez-Navarro A.B., OrtegaHuertas M., 2009. Thermal decomposition of calcite: Mechanisms of formation and textural evolution of $\mathrm{CaO}$ nanocrystals. American Mineralogist. 94, 578593, DOI: 10.2138/am.2009.3021.

Rosenberg R.A., Love P.J., Rehn V., 1986. Polarization-dependent C (K) near-edge xray-absorption fine structure of graphite. Physical Review B. 33, 4034, DOI: 10.1103/PhysRevB.33.4034.

Ruiz-Agudo E., Kudłacz K., Putnis C.V., Putnis A., Rodriguez-Navarro C., 2013. Dissolution and carbonation of portlandite $\left[\mathrm{Ca}(\mathrm{OH})_{2}\right]$ single crystals. Environmental science \& technology. 47, 11342-11349, DOI: 10.1021/es402061c. Sammis C.G., Ben-Zion Y., 2008. Mechanics of grain-size reduction in fault zones. Journal of Geophysical Research: Solid Earth 113.B2, DOI: 10.1029/2006JB004892.

Saxena R.R., Bragg R.H., 1978. Kinetics of graphitization in glassy carbon. Carbon. 16, 373-376, DOI: 10.1016/0008-6223(78)90077-5.

Scholz C.H., 1998. Earthquakes and friction laws. Nature. 391, 37, DOI: $10.1038 / 34097$.

Siman-Tov S., Aharonov E., Sagy A., Emmanuel S., 2013. Nanograins form carbonate fault mirrors. Geology. 41, 703-706, DOI: 10.1130/G34087.1. 
Smeraglia, L., Bettucci A., Billi A., Carminati E., Cavallo A., Di Toro G., Natali M., Passeri D., Rossi M., Spagnuolo E., 2017. Microstructural evidence for seismic and aseismic slips along clay-bearing, carbonate faults. Journal of Geophysical Research: Solid Earth 122.5, 3895-3915, DOI:10.1002/2017JB014042.

Smith S., Di Toro G., Kim S., Ree J., Nielsen S., Billi A., Spiess R., 2013. Coseismic recrystallization during shallow earthquake slip. Geology. 41, 63-66, DOI: 10.1130/G33588.1.

Spagnuolo E., Plümper O., Violay M., Cavallo A., Di Toro G., 2015. Fast-moving dislocations trigger flash weakening in carbonate-bearing faults during earthquakes. Scientific reports. 5, 16112, DOI: 10.1038/srep16112.

Stroud, R.M., Chisholm, M.F., Heck, P.R., Alexander, C.M., Nittler, L.R., 2011. Supernova shock-wave-induced co-formation of glassy carbon and nanodiamond. The Astrophysical Journal Letters. 738.2, L27, DOI: 10.1088/2041-8205/738/2/L27.

Tisato N., Di Toro G., De Rossi N., Quaresimin M., Candela T., 2012. Experimental investigation of flash weakening in limestone. Journal of Structural Geology. 38, 183-199, DOI: 10.1016/j.jsg.2011.11.017.

Toy V.G., Mitchell T.M., Druiventak A., Wirth R., 2015. Crystallographic preferred orientations may develop in nanocrystalline materials on fault planes due to surface energy interactions. Geochemistry, Geophysics, Geosystems. 16.8, 2549-2563, DOI: 10.1002/2015GC005857.

Verberne B.A., Spiers C.J., Niemeijer A.R., De Bresser J., De Winter D., Plümper O., 2014. Frictional properties and microstructure of calcite-rich fault gouges sheared at sub-seismic sliding velocities. Pure and Applied Geophysics. 171, 2617-2640, DOI: 10.1007/s00024-013-0760-0.

Vigano A., Tumiati S., Recchia S., Martin S., Marelli M., Rigon R., 2011. Carbonate pseudotachylytes: evidence for seismic faulting along carbonate faults. Terra Nova. 23, 187-194, DOI: 10.1111/j.1365-3121.2011.00997.x.

Wang Y., Alsmeyer D.C., McCreery R.L., 1990. Raman spectroscopy of carbon materials: structural basis of observed spectra. Chemistry of Materials. 2, 557563, DOI: 10.1021/cm00011a018.

Wojdyr M., 2010. Fityk: a general purpose peak fitting program. Journal of Applied Crystallography. 43, 1126-1128, DOI: 10.1107/S0021889810030499. 
Yund R.A., Blanpied M.L., Tullis T.E., Weeks J.D., 1990. Amorphous material in high strain experimental fault gouges. Journal of Geophysical Research: Solid Earth 95, 15589-15602, DOI:/10.1029/jb095ib10p15589.

Zhang, Z., Brydson, R., Aslam, Z., Reddy, S., Brown, A., Westwood, A., Rand, B., 2011. Investigating the structure of non-graphitising carbons using electron energy loss spectroscopy in the transmission electron microscope. Carbon. 49, 5049-5063. DOI: 10.1016/j.carbon.2011.07.023.

\section{Supplementary material}

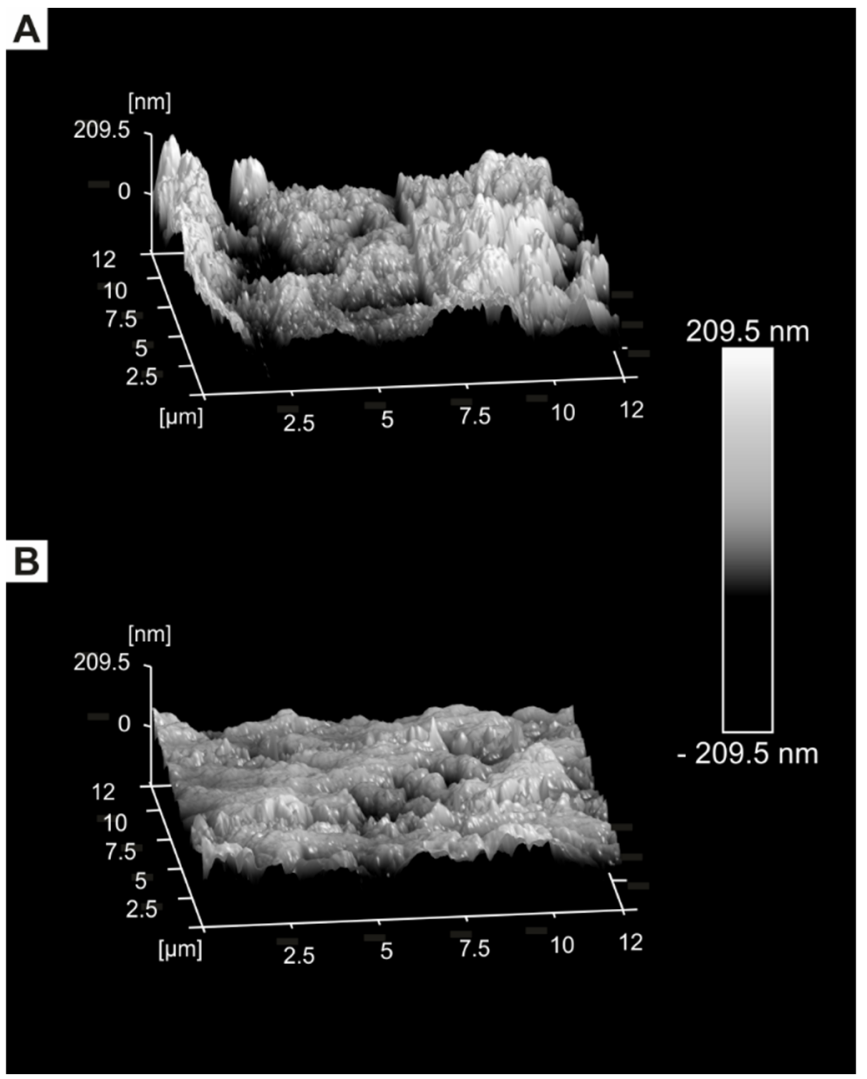

SF 1: Atomic force microscope measurements of the surface roughness of both fault exposures. A: Arkitsa fault surface with a calculated mean surface roughness of $63.5 \mathrm{~nm}$. B: Schinos fault surface with a calculated mean surface roughness of $32.3 \mathrm{~nm}$. 


\section{Chapter 2: Crystal-plastic deformation in seismically active carbonate fault rocks}

This chapter is published as the following publication: Ohl, M., Nzogang, B., Mussi, A., Wallis, D., Drury, M. E Plümper, O. (2021). Crystal-plastic deformation in seismically active carbonate fault rocks. Journal of Geophysical Research: Solid Earth. DOI: 10.1029/2020JB020626. 


\section{Abstract}

The spatial separation of macroscopic rheological behaviours has led to independent conceptual treatments of frictional failure, often referred to as brittle, and viscous deformation. Detailed microstructural investigations of naturally deformed carbonate rocks indicate that both, frictional failure, and viscous mechanisms might operate during seismic deformation of carbonates. Here, we investigate the deformation mechanisms that were active in two carbonate fault zones in Greece by performing detailed slip-system analyses on data from automated crystal-orientation mapping transmission electron microscopy and electron backscatter diffraction. We combine the slip system analyses with interpretations of nanostructures and predictions from deformation mechanism maps for calcite. The nanometric grains at the principal slip surface should deform by diffusion creep but the activation of the $(0001)<\overline{1} 2 \overline{1} 0>$ slip system is evidence for a contribution of crystal plasticity. A similar crystallographic preferred orientation appears in the cataclastic parts of the fault rocks despite exhibiting a larger grain size and a different fractal dimension, compared to the principal slip surface. The cataclastic region exhibits microstructures consistent with activation of the $(0001)<\overline{1} 2 \overline{1} 0>$ and $\{10 \overline{1} 4\}<\overline{2} 021>$ slip systems. Post-deformational, static recrystallisation and annealing produces an equilibrium microstructure with triple junctions and equant grain size. We propose that repeated introduction of plastic strain and recrystallisation reduces the grain size and offers a mechanism to form a cohesive nanogranular material. This formation mechanism leads to a grainboundary strengthening effect resulting in slip delocalisation which is observed over six orders of magnitude $(\mu \mathrm{m}-\mathrm{m})$ and is expressed by multiple faults planes, suggesting cyclic repetition of deformation, and annealing.

\subsection{Introduction}

Seismic slip and aseismic creep commonly occur in distinct portions of the lithosphere due to the different dependencies of the underlying deformation mechanisms on conditions such as pressure and temperature (Scholz, 1998). Frictional failure involves dilatant processes facilitated by low confining pressures at shallow depths (Sammis et al., 1987; Sammis and Ben-Zion, 2008), whereas viscous deformation occurs by thermally activated processes promoted by higher temperatures at greater depths (Sibson, 1982; Bürgmann and Dresen, 2008). However, the temperature-increase through shear heating during seismic faulting 
(Rice, 2006) challenges this strict separation by potentially activating temperaturedependent deformation mechanisms, such as crystal plasticity and diffusion creep (Nielsen, 2017). Depending on the material, melting or decomposition reactions can also occur at high temperatures, leading to severe microphysical changes that severely alter the mechanical behaviour of faults (Di Toro et al., 2011; Niemeijer et al., 2012). The main factor limiting the operation of crystal plasticity in the brittle regime is the extremely short duration of the temperature-increase during and after fault slip. Thermal models predict a temperature drop through thermal diffusion within one second after sliding ceases to a value similar to the background temperature (Di Toro and Pennacchioni, 2004; Demurtas et al., 2019). Therefore, a key objective of earthquake geology is to assess the extent to which thermally activated processes impact fault structure and properties e.g., modifying the microstructure or activation of deformation mechanisms, during the short interval of coseismic slip.

Deformed carbonates from principal slip zones of natural and experimental faults commonly exhibit crystallographic preferred orientations (CPOs) (Smith et al., 2013; Verberne et al., 2013; Delle Piane et al., 2017; Kim et al., 2018; Demurtas et al., 2019; Pozzi et al., 2019). Most of the CPOs involve (0001) planes aligned subparallel to the shear plane, typically with an antithetic inclination against the shear direction. In addition, the CPOs include alignment of the $<\overline{1} 2 \overline{1} 0>$ axes subparallel to the shear direction. Similar CPOs are generated in high-temperature, low-strain rate experiments, in which calcite is deformed by dislocation-mediated deformation mechanisms (Pieri et al., 2001). In general, the observations of CPOs in carbonate fault rocks suggest that crystal plasticity contributes to accommodating applied strain during seismic deformation. The contrast between frictional failure at the macroscale and the formation of CPOs by dislocation-mediated processes at the microscale demonstrates the need to further constrain the spatial and temporal evolution of deformation mechanisms during fault slip.

At the microscale, high-temperature grain-boundary sliding (GBS) has been suggested to operate within the gouge volume near the principal slip surface (PSS) (De Paola et al., 2015). In the pursuit of predicting rheological behaviour during seismic fault slip, De Paola et al. (2015) used deformation mechanism maps constructed from steady-state flow laws. For carbonates with small grain sizes, these flow laws predict the operation of grain-size sensitive (GSS) deformation mechanisms such as diffusion creep (Herwegh et al., 2003) and dislocation- 
accommodated grain boundary sliding (disGBS) (Walker et al., 1990). In contrast, coarse-grained carbonates are predicted to exhibit grain-size insensitive (GSI) behaviour inferred to result from dislocation glide and dislocation cross-slip (Renner et al., 2002; De Bresser, 2002). To reasonably use flow laws to predict rheological behaviour, flow-law parameters, such as the stress exponent, $n$, the grain size exponent, $\mathrm{p}$, and the activation energy, $\mathrm{Q}$ must be known. Most of the parameters are derived from laboratory experiments under well-constrained conditions and at steady state so that inferring these parameters for the materials in any particular natural fault zone can be challenging. Strain rates during experiments performed to constrain flow-law parameters are orders of magnitude lower than those occurring during seismic slip on natural faults and therefore, predicting deformation mechanisms during seismic deformation requires the flow laws to be extrapolated in stress/strain rate. It is challenging to test the accuracy of such extrapolations based on mechanical data from high-velocity deformation experiments, so microstructural analyses offer critical additional information against which to test the accuracy of flow-law predictions.

The present study continues previous work on the nanostructural processes of the same fault exposures. For more information and a detailed introduction to the geological background the reader is kindly referred to Ohl et al. (2020). In the present study, we characterise the micro- and nanostructures of natural carbonate fault rocks directly at a slip interface using multiscale crystallographic orientation analyses to evaluate deformation mechanisms during seismic events. The fault-rock microstructures reveal that crystal plasticity contributed during deformation and that the microstructure was potentially modified by recrystallisation.

\subsection{Geology and tectonic setting}

The first investigated fault exposure $\left(38^{\circ} 43^{\prime} 56.17^{\prime \prime} \mathrm{N}, 23^{\circ} 0^{\prime} 27.41^{\prime \prime} \mathrm{E}\right)$ is located close to Arkitsa, along the northern coast of the Gulf of Evia, Greece. This fault exposure is part of the Kamena Vourla fault system with a length of about $30-40 \mathrm{~km}$ (Ambraseys and Jackson, 1990). In general, the ESE-WNW-striking, N-dipping fault planes separate Triassic to Middle/Late Jurassic platform carbonates of the footwall from lower Pliocene-Pleistocene up to Quaternary hanging-wall sediments (Kokkalas et al., 2007). The footwall cataclasite is a greyish, matrix-supported fault rock with host-rock clasts (Fig. 1a, S1a and S1b). Multiple fault planes are hosted inside the damage zone, indicating fault-plane overstepping (Fig. 1b). Cumulative 
fault displacement is not mentioned or documented in the geological literature, but present days outcrop situation shows the fault rocks in contact with quaternary deposits. Records of historic seismicity document 13 events since 426 BC with the last major nearby event of $\mathrm{Ms}_{\mathrm{s}} 6.9$ in 1894 (Ambraseys and Jackson, 1990).

The second fault exposure ( $\left.38^{\circ} 2^{\prime} 14.40^{\prime \prime} \mathrm{N}, 23^{\circ} 0^{\prime} 22.33^{\prime \prime} \mathrm{E}\right)$ is located close to Schinos, Corinth area. Here, the fault exposure is part of a $\sim 25-\mathrm{km}$ long onshore fault line with an E-W strike, dipping towards N. The host rocks are Upper Triassic limestones and dolomites (Kaplanis et al., 2013) and a reddish cataclasite with lightgrey host-rock clasts forms the footwall fault rock (Fig. 1c, S1c and S1d). In the field, the fault-plane exposure shows at least one stepover (Fig. 1d). Cumulative fault displacement is not mentioned or documented in the geological literature, but present days outcrop situation shows the fault rocks in contact with quaternary colluvium deposits. The last seismic event in the region was recorded in February 1981, when three major events occurred with a maximum magnitude of $M_{s} 6.7$ (Collier et al., 1998).

Subduction-related back-arc volcanism, combined with extensional tectonics caused by rollback of the Hellenic subduction zone (Thomson et al., 1998), results in a high geothermal gradient across the Aegean region (Papachristou et al., 2014; Lambrakis et al., 2014). The geothermal gradient measured from geothermal exploration boreholes in the Sperchios basin, approx. $50 \mathrm{~km}$ west of Arkitsa, is 35 ${ }^{\circ} \mathrm{C} / 100 \mathrm{~m}$ (Metaxas et al., 2010). Similar measurements at Kamena Vourla indicate 46 ${ }^{\circ} \mathrm{C}$ at $200 \mathrm{~m}$ depth (Mendrinos et al., 2010). Clay-mineral assemblages in the Arkitsa fault formed from $100-150{ }^{\circ} \mathrm{C}$ (Papoulis et al., 2013). However, the clays are found inside the hanging-wall breccia and may not reflect the processes and temperatures on the fault plane. Also, in the Sousaki-Loutraki region close to Schinos, geothermal exploration drilling revealed high temperatures at shallow depth. In this region, (Mendrinos et al., 2010) measured $63^{\circ} \mathrm{C}$ at 500-1100 $\mathrm{m}$ depth, which is in agreement with (Lambrakis et al., 2014) obtaining $\geq 75{ }^{\circ} \mathrm{C}$ at $600-900 \mathrm{~m}$ depth. Because the above-mentioned temperature indications stem from geothermal explorations, it is not clear whether they represent temperatures of host rock or fluid temperatures. However, thermal models of the Aegean region predict temperatures from $200{ }^{\circ} \mathrm{C}$ (Limberger et al., 2014) to $360{ }^{\circ} \mathrm{C}$ (Larède, 2018) at $5 \mathrm{~km}$ depth. 


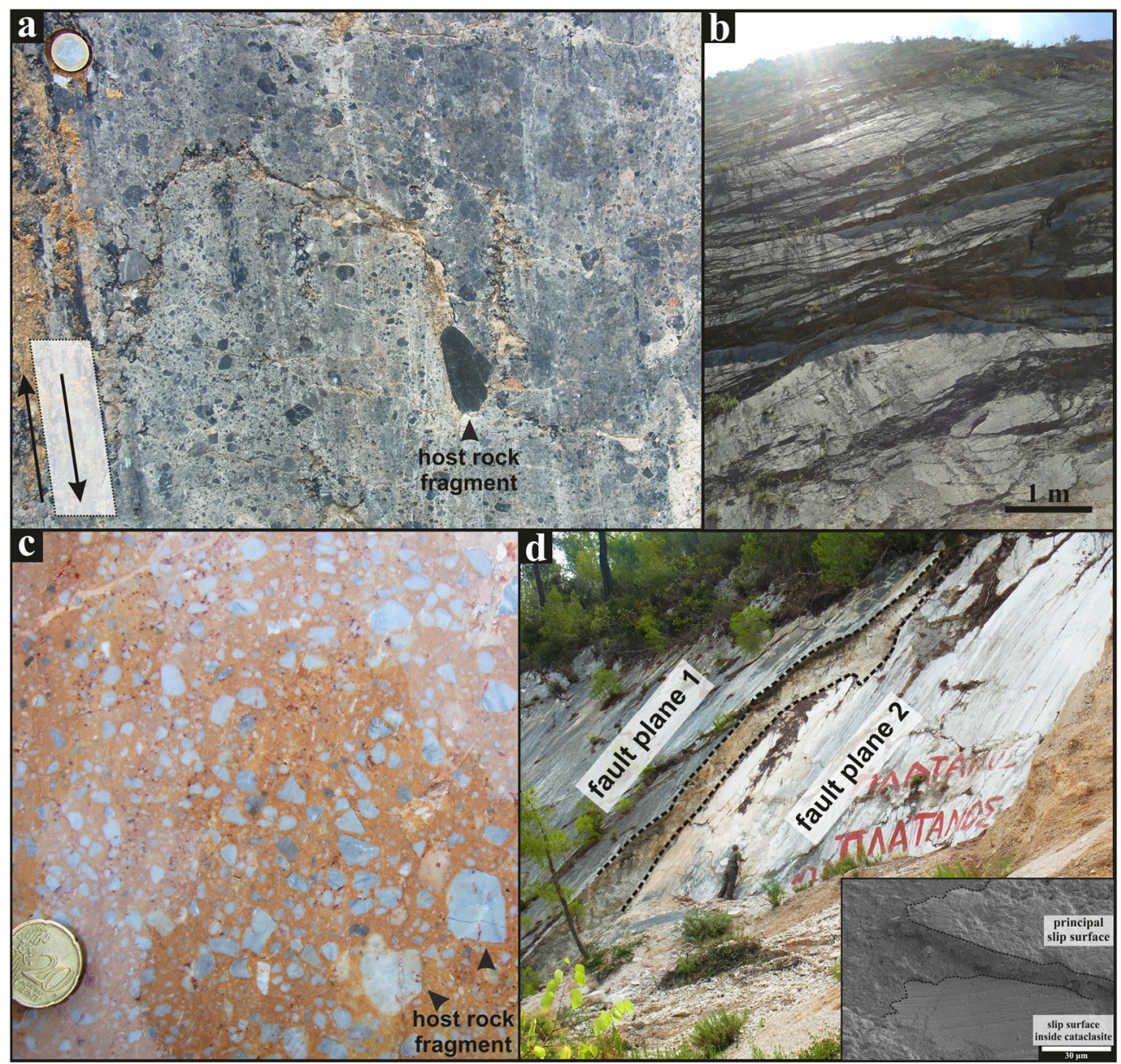

Figure 1: Overview of geological features. a: View onto Arkitsa fault plane. Dark, large host-rock clasts are incorporated into the light-grey footwall cataclasite. Arrow indicates slip direction. One-Euro coin for scale. $\underline{b}$ : Multiple slip planes hosted inside the damage zone of the Arkitsa fault exposure exhibit overstepping. $\underline{c}$ : View onto Schinos fault plane. Light-grey host rock clasts incorporated into red hanging-wall cataclasite. $\underline{d}$ : Field view of Schinos fault plane exposure. Two distinct and overstepping fault planes are visible, hosted inside the damage zone. Person for scale. Inset: Secondary electron image showing development of secondary slip surface inside the Schinos footwall cataclasite. The secondary slip surface is situated about $10 \mu \mathrm{m}$ below the principal slip surface.

\subsection{Methods}

\subsubsection{Crystal orientation acquisition}

Thin sections were prepared from drill cores by cutting parallel to the slip direction and normal to the slip surface. Electron backscatter diffraction (EBSD) data were acquired using a Philips XL30 scanning electron microscope (SEM) equipped with an Oxford Instruments Nordlys 2 CCD camera. Maps were acquired with an accelerating voltage of $30 \mathrm{kV}$, probe current of $9.5 \mathrm{nA}$, and step size of $0.5 \mu \mathrm{m}$ for the 
Arkitsa sample and $20 \mathrm{kV}$ accelerating voltage, $9.5 \mathrm{nA}$ probe current, $0.7 \mu \mathrm{m}$ step size for the Schinos sample.

Crystal-orientation data were also acquired in a transmission electron microscope (TEM) using the automatic crystal orientation mapping technique (ACOM-TEM, (Rauch and Véron, 2014)). TEM foils were prepared with a FEI Helios G3 focussed ion-beam scanning electron microscope (FIB-SEM). ACOM-TEM data were acquired using the NanoMEGAS ASTAR/SPINSTAR system on a FEI Tecnai G²-20 twin. Beam conditions during ACOM-TEM were $200 \mathrm{kV}$ and spot size 11, giving a nominal $1 \mathrm{~nm}$ probe diameter, resulting in a step size of $2 \mathrm{~nm}$. During acquisition, the primary electron beam was set to precession movement, with an opening angle of $0.5^{\circ}$. In a separate step, the acquired electron diffraction patterns were matched with a pre-calculated bank file containing the simulated crystal orientations in kinematic conditions, resulting in a unique crystal-orientation solution.

\subsubsection{Data treatment}

Orientation data from EBSD and ACOM-TEM were processed using the MTEX 4.5.2 toolbox (Hielscher and Schaeben, 2008; Bachmann et al., 2011). The reference frame was set to x-axis to the east, $y$-axis to the south and z-axis out of plane. Grain boundaries were defined as misorientation angles $>10^{\circ}$ and subgrain boundaries were defined as misorientation angles in the range $1-10^{\circ}$ for ESBD and $2-10^{\circ}$ for ACOM-TEM. Unindexed pixels or single pixels matched as a different phase were removed and unindexed pixels were filled with the average orientation of their grain neighbours. Grains $<5$ pixels were removed from EBSD datasets. Grains and subgrains $<20$ pixels were removed from the ACOM-TEM dataset. A Kuwahara filter with a kernel size of 5x5 was applied to the ACOM dataset to reduce orientation noise. All crystal orientation plots were visualized before denoising to guard against the introduction of artefacts. Contoured pole figures are based on onepoint-per-grain orientation data. The optimum half-width for contoured EBSD pole figures was estimated using the De la Vallée Poussin kernel approach. Because this estimation was inconsistent with the low estimated optimum half-width for the ACOM-TEM data, we chose $15^{\circ}$ to match the EBSD pole figures. Misorientation inverse pole figures (MIPF) were plotted for subgrain-boundary misorientation angles of $1-10^{\circ}$ for EBSD and $2-10^{\circ}$ for ACOM-TEM. 


\subsubsection{Grain size analysis}

A grain-size distribution was determined from the EBSD and ACOM-TEM data. The ACOM-TEM grain-size distribution was based on a grain-boundary trace map by combining a reliability map and an indexed crystal-orientation map. In order to ensure comparability of EBSD and ACOM-TEM data fractal dimension analysis, the calculated grain-size frequencies from the ACOM-TEM data were scaled with the difference in area resolution, due to differences in step size, by a factor of 62500 . In this procedure, a 500x500 nm pixel (EBSD) was divided by a $2 \times 2$ $\mathrm{nm}$ pixel (ACOM-TEM) which equates to the factor of 62500 . To obtain a grain-size distribution, we chose the dataset binning to be continuous (i.e., equal to the mapping step size), to reduce undersampling of small grains. Each dataset was individually fitted with a linear equation where the negative slope of the linear fit in $\log$-log space equals the fractal dimension $D$. The grain-size bin width for the fractaldimension plot was set to $1 \mu \mathrm{m}$ to adequately subdivide for the large number of small grains.

\subsection{Results}

\subsubsection{Microscale crystal orientation data}

Figure 2a presents the EBSD map of the Arkitsa footwall cataclasite. The map exhibits small matrix-forming grains and larger host-rock clasts, where the clasts show an internal fine-grained foam microstructure. The fine-grained matrix and the foam microstructure display straight grain boundaries that meet in $120^{\circ}$ triple junctions (Fig. 2c and a). Grain boundaries are typically not aligned over distances greater than one grain diameter. Monocrystalline calcite clasts occasionally host twin lamellae. An elongated host-rock grain at the top left of Figure 3a exhibits a gradual increase of small grains from monocrystalline to polycrystalline calcite. The median grain size is $5.0 \mu \mathrm{m}$ (Fig. 2b). MIPFs for each subset in Figure 2a reveal concentrations of misorientation axes approximately centred on [0001]. The pole figures of (0001) and $<\overline{1} 2 \overline{1} 0>$ (Fig. 2d) display a weak CPO with multiples of uniform distribution (MUD) in the range 0.8-1.2. The (0001) planes are parallel to the slip plane and the $<\overline{1} 2 \overline{1} 0>$ axes are parallel to the slip direction (noting the orientation of the trace of the slip surface at the top right of Fig. 2a). The subgrain-boundary MIPF for the overall map data exhibits a cluster of misorientation axes parallel to [0001] (Fig. 2e), like the individual subsets in Fig 2a. 
Figure 3a presents the EBSD results from the Schinos footwall cataclasite. The band-contrast map reveals a microstructure with large calcite host-rock grains incorporated into the cataclasite matrix. Like Figure 2a, several host-rock grains exhibit an increase of small grains from monocrystalline to polycrystalline (Fig. 3c). Whilst many grain boundaries are curved, several in both, the matrix and host-rock grains are straight and meet in $120^{\circ}$ triple junctions (Figure 3c, white circles). The outer margins of the host-rock grains display a rim with grain boundaries, creating an incipient core-mantle structure (Fig. 3c). The median grain-size is $4.4 \mu \mathrm{m}$. (Fig. $3 b)$. The pole figures in Figure $3 \mathrm{~d}$ display a weak CPO with multiples of uniform distribution (MUD) in the range 0.8-1.2. The (0001) planes are parallel to the slip plane and the $<\overline{1} 2 \overline{1} 0>$ axes are parallel to the slip direction. Furthermore, $\{10 \overline{1} 4\}$ poles exhibit a weak cluster approximately parallel to the slip-plane normal and the $<2021>$ axes exhibit three maxima sub-perpendicular to the slip plane. In addition, $\{\overline{1} 012\}$ planes exhibit one maximum and a girdle, whereas $<10 \overline{1} 1>$ directions are oriented perpendicular to the slip plane. MIPFs for subgrain-boundary misorientation axes in each vertical section in Figure 3a exhibit a pronounced maximum centred on the $\langle\mathrm{a}>$ direction. Secondary maxima are centred on $\langle\mathrm{m}\rangle,\langle\mathrm{c}\rangle$, or $\langle\mathrm{a}\rangle$, or a combination of all three directions. The overall MIPF in Figure 3e exhibits subgrain misorientation axes predominantly around $<\mathrm{a}>$, consistent with most misorientation axes in the vertical sections from Figure $3 a$. 


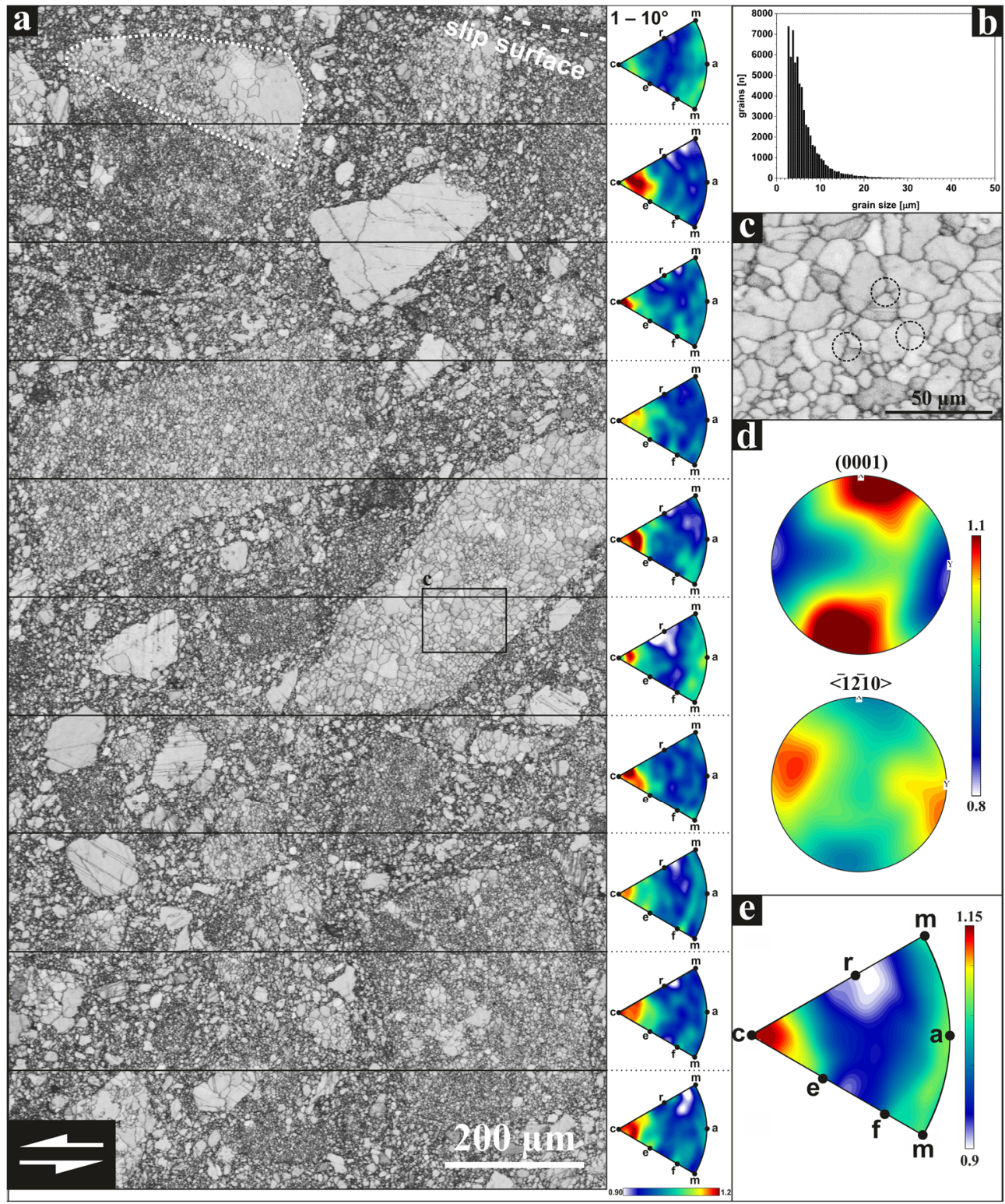

Figure 2: Electron-backscatter diffraction results of the Arkitsa fault-exposure cataclasite. a: Band-contrast map and MIPF for each subsection. Fault surface with hanging-wall in top-right corner. $\boldsymbol{b}$ : Grain-size distribution. ntotal $=$ 78143. c: Detailed view of host-rock clast microstructure. Black circles mark triple junctions and $120^{\circ}$ angles. $\underline{d}$ : Pole plots of (0001) planes and $<\overline{1} 2 \overline{1} 0>$ axes in the same reference frame as the map in a. : MIPF of the full map area. Labels indicate crystal directions or plane normals. Contours are multiples of uniform distribution. 


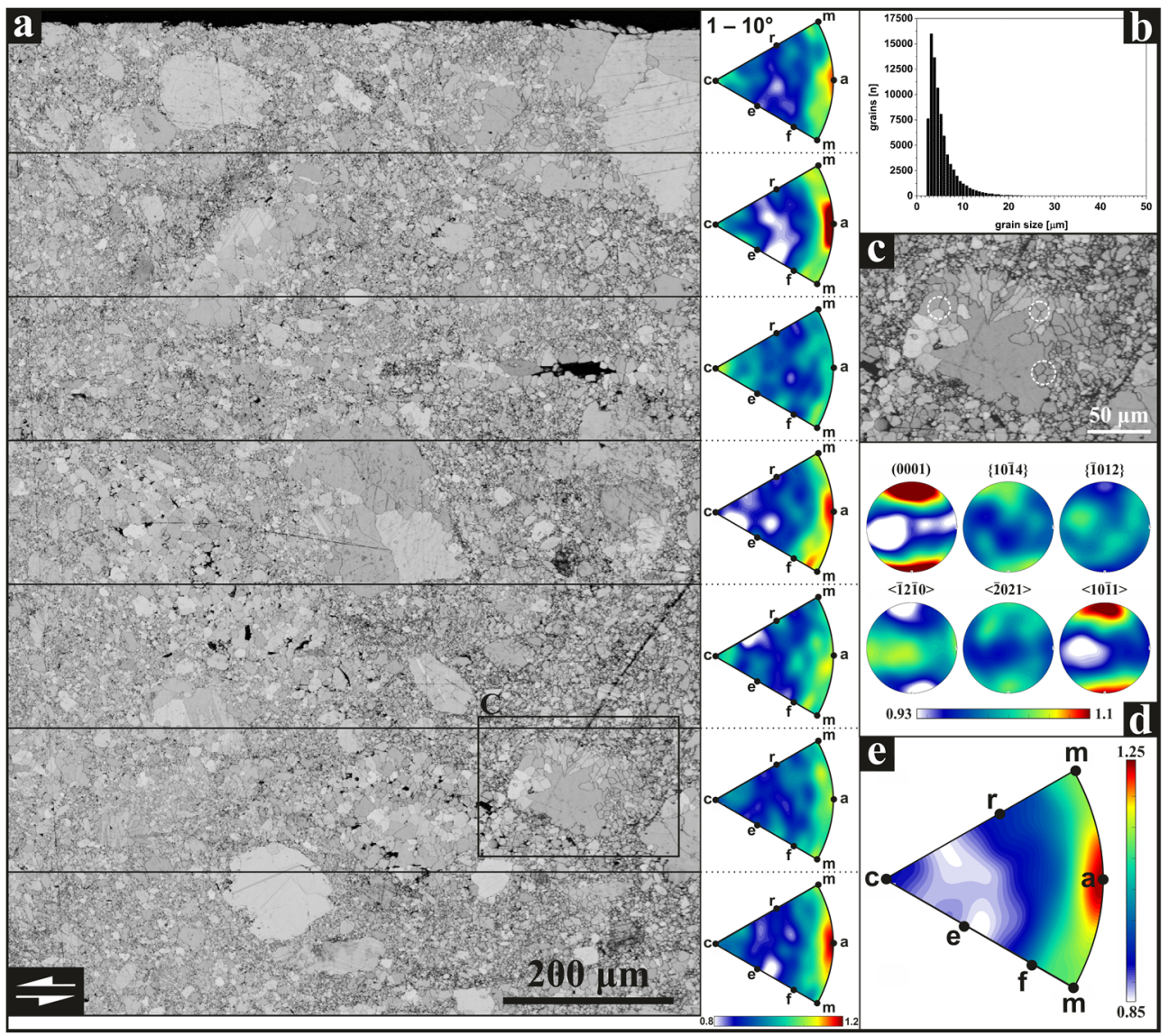

Figure 3: Electron-backscatter diffraction results of the Schinos fault-exposure cataclasite. a: Band-contrast map

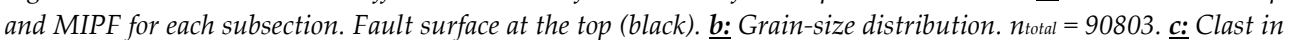
matrix displaying a mantle of grains around a host-rock clast with internal triple junctions (white dashed circle). $\underline{d}$ :

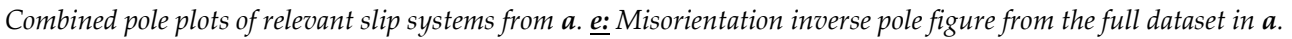

\subsubsection{Nanostructures}

TEM investigation of the Arkitsa fault rock also reveals a fine-grained volume situated on top of coarser grains (Fig. 4a). The first 15-20 $\mu \mathrm{m}$ of material directly below the PSS exhibits a foam nanostructure. This foam nanostructure consists of grains with approximately equal grain size and straight grain boundaries that meet in triple junctions with $120^{\circ}$ angles (Fig. 4c). The grains in this zone are commonly sandwiched between, and overprinted by, microstructural discontinuities (e.g., Fig. 4c, white lines) dipping at an angle of about $30^{\circ}$ to the slip surface into the nanogranular material. The discontinuities can displace single grains (Fig. $4 \mathrm{~b}$ and c) or form bands of localised deformation with a sigmoidal appearance, preserving the intact foam nanostructure in between (Fig $4 \mathrm{~b}$ and $\mathrm{d}$ ). In 
Figure 4c, grains with similar diffraction contrast are displaced about $220 \mathrm{~nm}$ along such microstructural discontinuities. These discontinuities cannot be traced to the slip surface (Fig. 4c) but terminate in an area with a smaller grain of $\sim 50 \mathrm{~nm}$ size below the PSS (Fig. 4c) compared to $\sim 300 \mathrm{~nm}$ further away from the PSS (Fig. 6, grain No. 3). Larger grains are occasionally intermingled with the nanogranular material (Fig. 4a). Below the nanogranular material, twinned calcite grains of 3-5 $\mathrm{mm}$ in diameter mark the beginning of the cataclasite (Fig. 4a). The grain size at the transition between the slip-surface nanostructure and the larger grains corresponds to the grain sizes observed in the EBSD map (Fig. 4 and d).

Figures $5 \mathrm{a}$ and $\mathrm{b}$ present the nanostructure of the Schinos fault directly at the PSS. Compared to the Arkitsa sample (Figure 4a and c), the grain size is larger, resulting in a less complex nanostructure. The Schinos nanostructure exhibits straight grain-boundary morphology with triple junctions (Fig. 5a) and subgrain boundaries (Fig. 5b). The average dislocation density in the larger Schinos grains is $\sim 1.5 \times 10^{13} \mathrm{~m}^{-2}$. The dislocation density decreases towards the subgrain boundaries but otherwise the distribution is generally homogeneous except for some subgrain interiors that are devoid of dislocations (Fig. 5b).

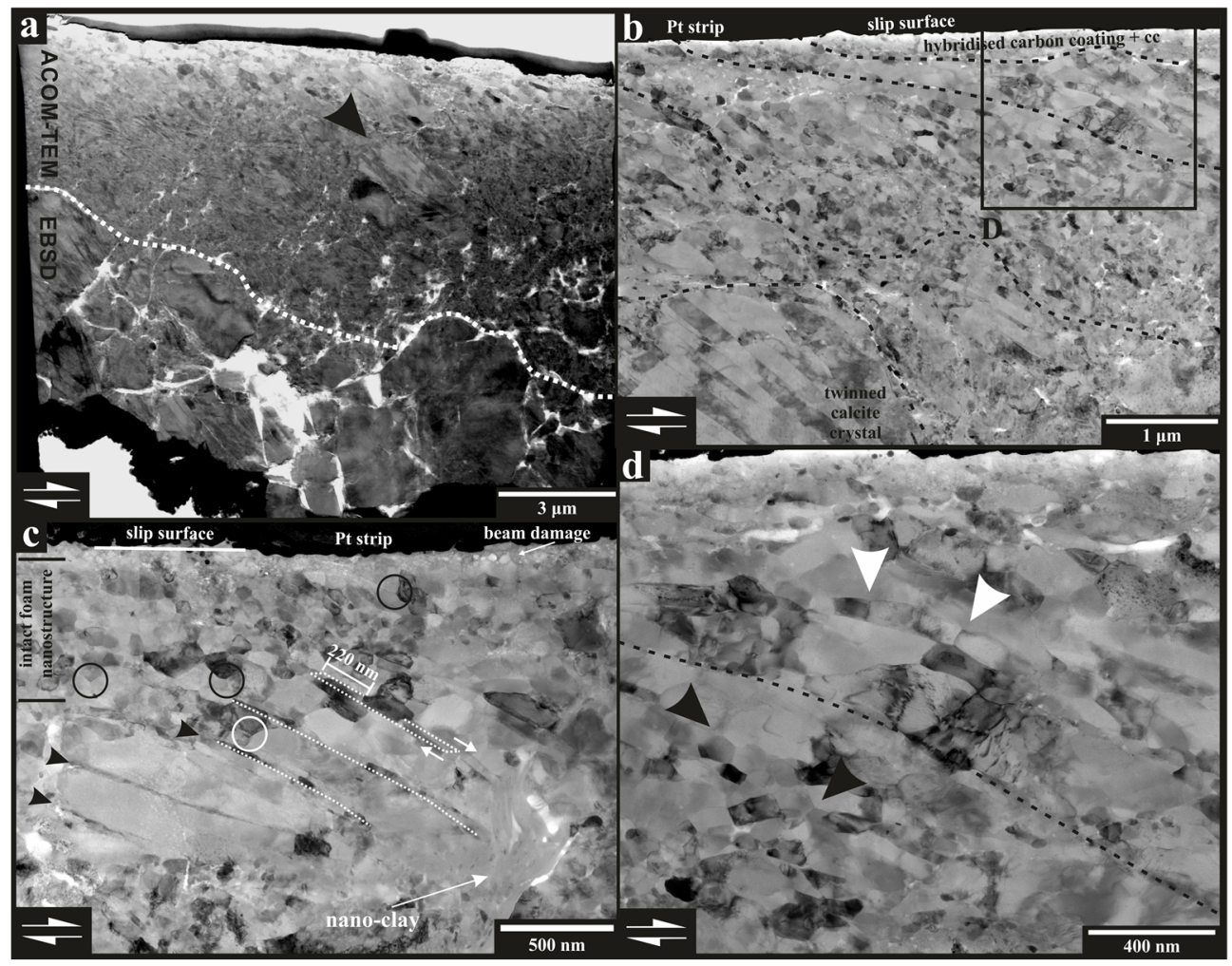


Figure 4: (previous page) Arkitsa fault exposure nanostructures. a: Bright-field (BF) TEM overview of deformed volume with a sharp boundary to the footwall cataclasite (dashed line). Larger grains show strong deformation (black arrow). The grain size of the less deformed grains is about 3-5 $\mu \mathrm{m}$. $\underline{\boldsymbol{b}}$ : Bright-field STEM image with detailed view of the deformed volume. Anastomosing boundaries separate alternating domains of deformed and intact foam nanostructure (dashed lines). c: Bright-field STEM image showing intact foam nanostructure with triple junctions and $120^{\circ}$ angles adjacent to the slip surface (black circles). Fractures that dissect grains terminate inside intact foam nanostructure. Fractures appear to evolve from former cleavage planes (black arrows). Older foam nanostructure is preserved between fracture planes (white circle). $\underline{d}$ : Bright-field STEM image of detailed view from $\boldsymbol{b}$. Deformed foam nanostructure with former triple junctions while having a sheet-like structure (white arrows) next to intact foam nanostructure (black arrows).

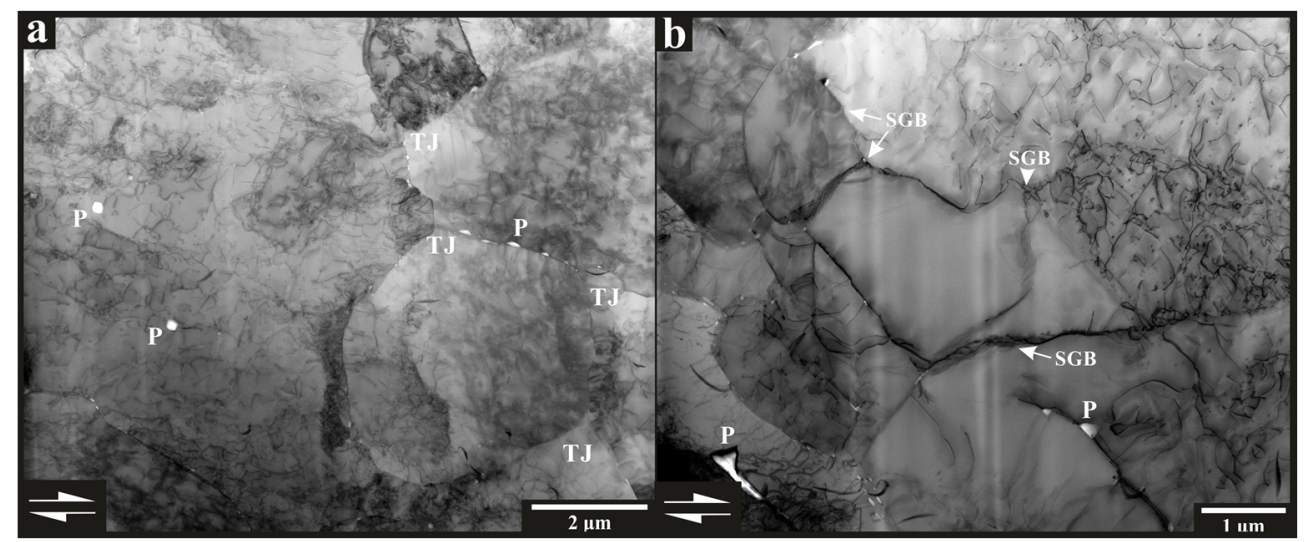

Figure 5: Schinos fault exposure nanostructures. a: BF-STEM image with overview of dislocation structure showing triple junctions (TJ) and grains with dislocation densities of $1.5 \times 10^{13} \mathrm{~m}^{-2}$ and higher. $\underline{\boldsymbol{b}}$ : BF-STEM image with dislocation-free subgrain in the centre surrounded by subgrain boundaries (SGB). Dislocation density of surrounding grain interiors decreases towards the SGBs. $P=$ pores.

\subsubsection{Nanoscale crystal orientation (ACOM-TEM)}

Figure 6 presents the ACOM-TEM data acquired on a subset of the same FIB foil shown in Figure 4c, reproducing the bright field (BF-)TEM nanostructure (Fig. $4 c, 6 a$ and b). Pole figures constructed from the crystal-orientation map exhibit a $\mathrm{CPO}$ with (0001) plane-normal densities in the range 0.4-2.0 MUD in the highly deformed, fine-grained region below the PSS. Some grains exhibit an orientation spread indicating intragranular misorientation (Fig. 6b). The median grain-size is 21 $\mathrm{nm}$ (Fig. 6c), albeit ranging between 5 to $300 \mathrm{~nm}$. Contoured pole figures (Fig. 6c) reveal a CPO with [0001] axes oriented perpendicular to the slip surface and $<\overline{1} 2 \overline{1} 0>$ axes clustered sub-parallel to slip direction. A second clustering of $\langle\overline{1} 2 \overline{1} 0>$ axes appear as a ring around the centre of the pole figure. The MIPF of the subgrain misorientation axes exhibits maxima parallel to [c] and $<\mathrm{m}>$. 


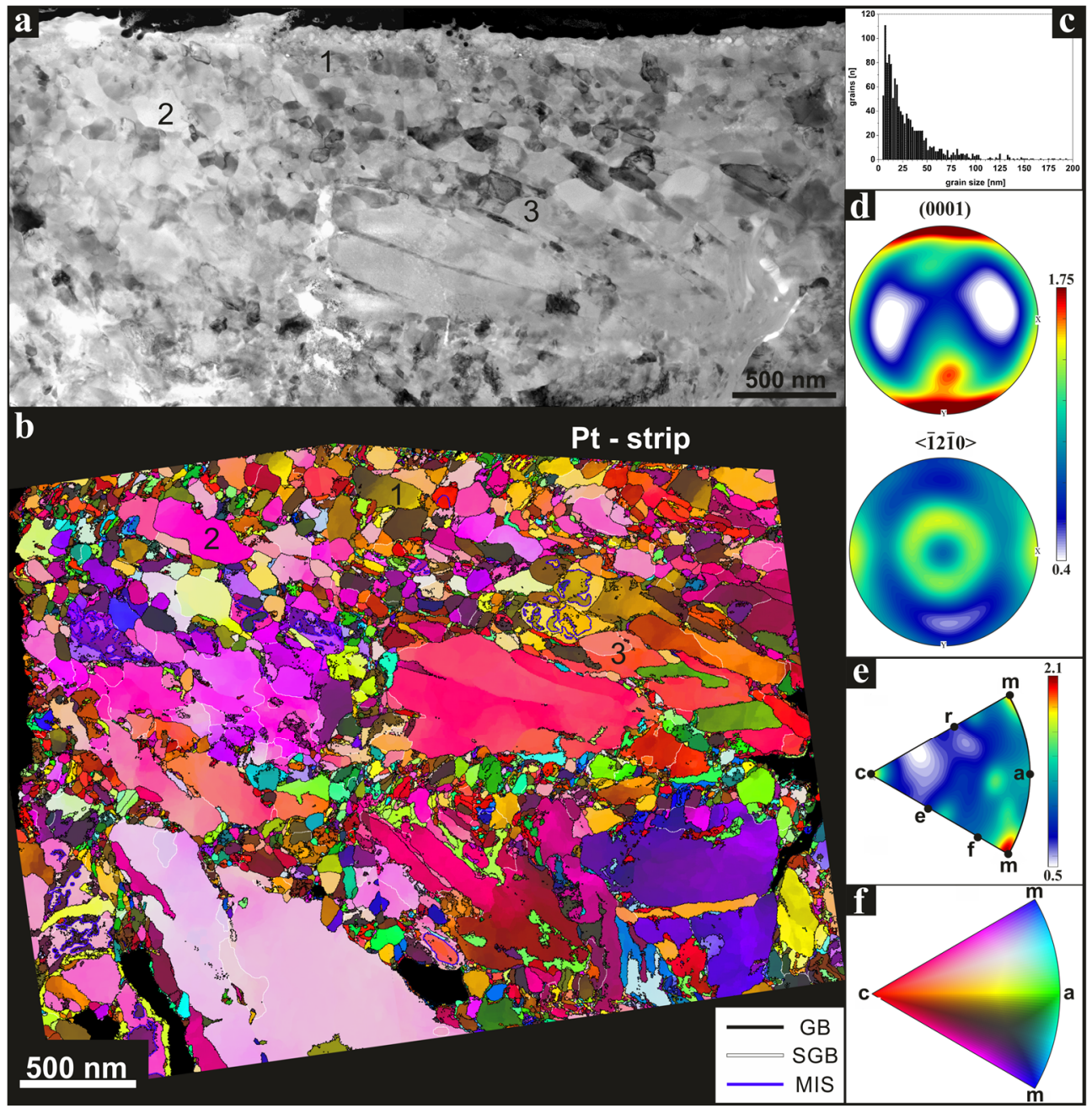

Figure 6: Nanoscale crystal orientation map. Numbers indicate the same grains for comparison between $\boldsymbol{a}$ and $\boldsymbol{b}$. $\boldsymbol{a}$ : BF-STEM image from Figure 4C. $\underline{\boldsymbol{b}}$ : Crystal-orientation map colour-coded according to the inverse pole figure in $f$ indicating the crystal direction aligned with the $Y$-axis of the map. c: Grain-size distribution of map in $\boldsymbol{b}$. $\underline{\boldsymbol{d}}$ : Contoured pole figures of (0001) poles and $<\overline{1} 2 \overline{1} 0>$ axes. $\underline{e}$ : MIPF of misorientation axes associated with misorientation angles in the range $2-10^{\circ}$. $f$ : IPF-Y colour key for map in $\boldsymbol{b}$. GB $=$ Grain boundary, SGB $=S$ ubgrain boundary, MIS = Misindexed grain boundary. Due to the electron-transparent nature of the FIB foil and corresponding diffraction behaviour, grain boundary morphologies are less well defined in the ACOM-TEM data compared to the BF-STEM image.

\subsubsection{Grain-size distribution}

Figure 7 presents a log-log plot of relative frequency as a function of grain size from the EBSD and ACOM-TEM data. A data gap between $350 \mathrm{~nm}$ and $2 \mu \mathrm{m}$ arises from the different spatial resolutions and area coverage of the two techniques. The EBSD-based fractal dimension of the Arkitsa fault exposure is $D=2.887\left(\mathrm{R}^{2}=\right.$ 
0.912), while the fractal dimension of the ACOM-TEM data is $D=1.574\left(\mathrm{R}^{2}=0.895\right)$.

The EBSD-based fractal dimension of the Schinos sample is $D=2.833\left(\mathrm{R}^{2}=0.902\right)$. Extrapolations of the grain-size distributions measured from the two different image datasets intersect at a grain size of approximately $1 \mu \mathrm{m}$.

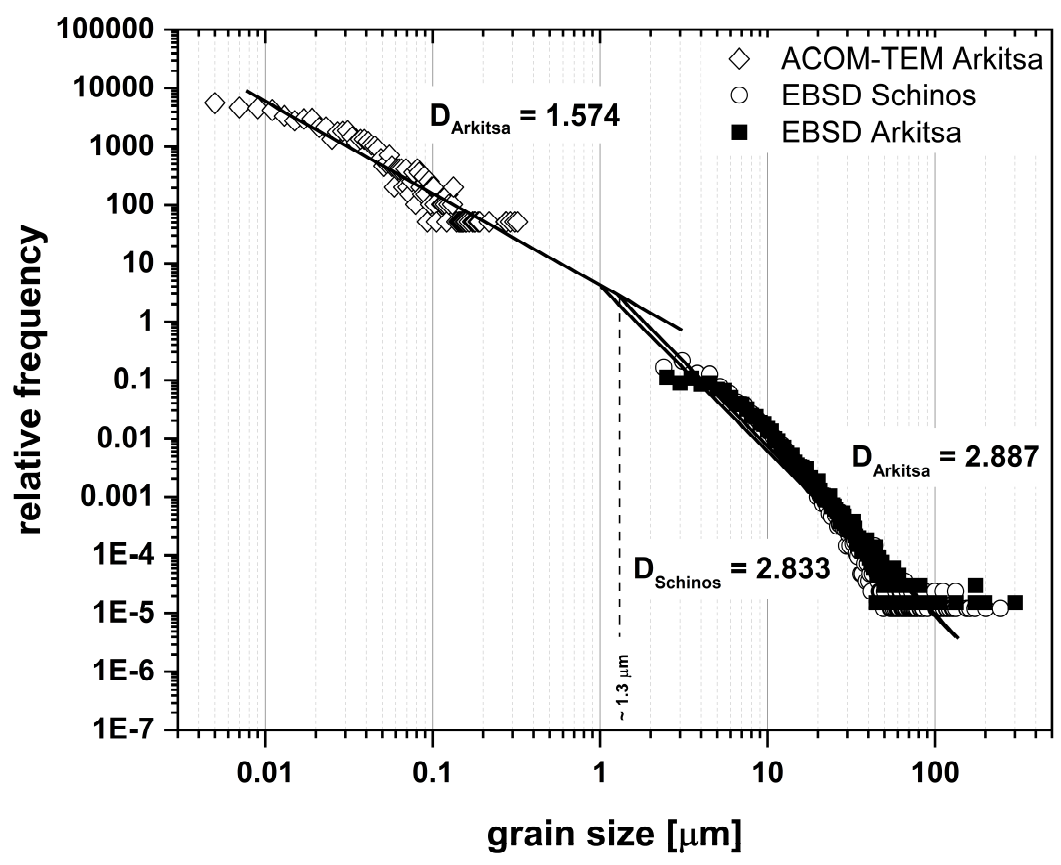

Figure 7: Fractal dimension plot of grain-size data from both fault exposures. The fractal dimensions of the Arkitsa datasets are $D=2.887$ (EBSD) and $D=1.574$ ( $A C O M-T E M)$. The fractal dimension of the Schinos dataset is $D=$ $2.833(E B S D)$.

\subsection{Discussion}

\subsubsection{Grain fragmentation and fractal dimensions}

Brecciation and cataclasis are important mechanisms of grain-size reduction in fault zones. Whereas intragranular extensional fracturing governs cataclasis during early fault-slip through particle-particle fragmentation, chipping governs the late stages during which grain edges are removed after greater amounts of fault displacement (Billi, 2010; Ferraro et al., 2018). Cataclasis can produce different grainsize distributions with fractal dimensions $(D)$ that provide information on the characteristics of fracturing (e.g., Sammis et al., 1986; Sammis et al., 1987 and Blenkinsop, 1991). For example, a fractal dimension of $D=2.580$ can result from the 
self-similar fracturing of a three-dimensional object, such as a cube. In addition to obtaining $D$ via linear fitting, one can also determine $D$ via:

$$
D=\frac{3 \log (\mathrm{f})}{\log (\mathrm{F})}+3
$$

where $F$ is the number of fragments created, and $f$ is the fragmentation fraction, defined as $f=C / F$, with $C$ being the number of fragments that are fragmented further. Fragmentation of a cube produces eight cubes $(F=8)$ of $1 / 2$ the width of the original cube (Heilbronner and Barrett, 2014). With $F=8$, it follows that for $f=8 / 8,100 \%$ of the newly formed grains are fragmented again, which results in a fractal dimension of $D=3.000$. Our fractal dimensions of $D=2.887$ and $D=2.833$ (Fig. 7) can be achieved with a fragmentation fraction of $f=7 / 8$, giving $D=2.807$. Such high $D$ values are reported for natural faults with intense grain-size reduction (Billi and Storti, 2004) and are predicted by numerical simulations (Abe and Mair, 2005). The agreement between the theoretical and our measured values suggests that the cataclasite experienced a high degree of fragmentation due to particle-particle interaction. Furthermore, a value of $D=1.574$ from ACOM-TEM (Fig. 7) may correspond to a low degree of fragmentation with $f=3 / 8$ yielding $D=1.585$ (see eq. 1). We propose that the difference in $D$ between the bulk cataclasite and the nanogranular volume arises from a difference in the degree of fragmentation. A lower $D$ of 1.574 may, therefore, indicate a different control on particle size involving a minor degree of particle-particle fragmentation. We suggest that the change in fractal dimension within the same fault rock may reflect a change in fragmentation and thus deformation mechanisms, as also proposed by Keulen et al. (2007).

\subsubsection{Nanostructures}

The Arkitsa and Schinos faults exhibit different nanostructures in their principal slip zones (PSZs). Whereas the PSZ of the Arkitsa fault is complex directly below the slip surface and includes a layer of nanograins (Figs. 4 and 6), the PSZ of the Schinos fault exhibits a similar grain size as its bulk fault rock (Figs. 3 and 5). We propose the difference in nanostructural complexity are because the Schinos fault represents an earlier stage of fault-rock evolution, while the Arkitsa fault accommodated multiple slip events over an extended deformation history.

Slip along the PSS would result in the introduction of plastic strain accompanied by a thermal spike through shear heating (Rice 2006) during a seismic event. The Schinos nanostructure, with a high, free dislocation density and triple junctions (Fig. 5a and b), resembles that of metals subjected to a process known as 
cold-rolling and annealing (Humphreys and Hatherly, 2004). The procedure involves the introduction of high plastic strain followed by static high-temperature treatment to induce microstructural changes. The typical range for industrial coldrolling is about $60-180{ }^{\circ} \mathrm{C}$ (Hollandt et al., 2010), corresponding to 0.05-0.11 times the melting temperature, $T_{m}$, for steel. It is likely that the temperature during the onset of slip of the carbonate faults was at a homologous temperature of about 0.2 $T_{m}\left(300{ }^{\circ} \mathrm{C}\right)$. Cold-rolling and subsequent annealing is a well-established process in engineering leading to grain-boundary migration and recrystallisation (Humphreys and Hatherly, 2004). Dislocation introduction through strain pulses in the lowtemperature plasticity regime can result in strain-hardening effects. Addition of thermal energy through heating enables dislocation climb and solid-state diffusion, leading to recovery or recrystallisation by static grain growth or grain boundary migration. The resulting grain size post annealing is smaller compared to the previous microstructure leading to grain-boundary strengthening and hence, toughening of the material. Such deformation processes followed by annealing of the material are already documented in experimentally and naturally deformed olivine (Druiventak et al., 2012; Matysiak and Trepmann, 2012) and quartz (Trepmann and Stöckhert, 2013; Trepmann et al., 2017). Repeated straining and subsequent annealing can lead to grain-size reduction and may, therefore, pose a mechanism of nanograin formation.

The $120^{\circ}$ triple junctions of the Arkitsa nanostructure may indicate annealing by grain boundary migration (Figs. 2 and 4). Static recrystallization involves an initial stage during which deformed grains with high, stored strain energy are replaced by recrystallized grains, which may then continue to grow. To evaluate whether significant grain growth can occur during the postseismic and inter-seismic period, we use the following kinetic model (Covey-Crump, 1997):

$$
d^{1 / n}-d_{0}^{1 / n}=k t=k_{0} t \exp (-H / R T)
$$

where $d$ is the final grain size, $d_{0}$ the initial grain size, $n$ is a dimensionless constant, $k_{0}$ is a pre-exponential factor, $t$ the duration of grain growth and $H$ is the apparent activation enthalpy. The values of $n$ and $H$ depend on the growth-controlling process. In the case of a grain-boundary controlled system, with no second phases (pure system) $n=0.5$. For an impure system where coalescence of a second phase occurs by volume diffusion (wet case) $n=0.33$ and for an impure system where coalescence of a second phase occurs by grain-boundary diffusion, $n=0.25$ (CoveyCrump, 1997). Assuming fluid-present conditions based on observations that 
suggest the presence of portlandite $\left(\mathrm{Ca}(\mathrm{OH})_{2}\right)$ during deformation (Ohl et al. 2020), we set $n=0.33$. This interpretation results in the following parameters: $k_{0}=2.514 \mathrm{x}$ $10^{9} \mu \mathrm{m}^{1 / \mathrm{n}} \mathrm{s}^{-1}, 1 / n \approx 3$ and $H=173.6 \mathrm{~kJ}$ mol-1 (Covey-Crump, 1997). To assess the potential for fluid-assisted post-seismic grain growth due to the ambient temperature at depth, we consider the borehole temperatures from the outcrop areas (Metaxas et al., 2010; Papoulis et al., 2013; Lambrakis et al., 2014). We assume a geothermal gradient of $65-75^{\circ} \mathrm{C} / \mathrm{km}$ and a typical seismogenic crustal depth of 3-5 $\mathrm{km}$ (Scholz, 1988) resulting in an ambient temperature of about $300{ }^{\circ} \mathrm{C}$. Annealing of the nanostructure for one year, at a temperature of $300^{\circ} \mathrm{C}$, with $d_{0}=0.1 \mu \mathrm{m}$, leads to a final grain size of $d=2.3 \mu \mathrm{m}$. Therefore, not only under short-lived, co-seismic temperature spikes but also during the inter-seismic period, grain growth may contribute to the formation and modification of the microstructure. However, the grain-size distribution in Figure $6 \mathrm{~b}$ contains grains $<50 \mathrm{~nm}$ in size, illustrating that our grain-growth approximation provides an upper limit. Nonetheless, our assessment of inter-seismic grain growth supports our suggestion that a cohesive nanogranular fault rock may be generated by high-plastic strain deformation and short annealing times.

\subsubsection{Deformation mechanisms}

\subsubsection{Grain-boundary sliding}

GBS has been proposed as a deformation mechanism for fine-grained fault rocks during seismic slip (De Paola et al., 2015). Langdon (2006) describes two possible types of GBS: Rachinger sliding and Lifshitz sliding. Rachinger sliding is defined by the relative displacement of adjacent grains, with strain compatibility maintained by dislocation motion in grain interiors. Therefore, Rachinger sliding is commonly referred to as dislocation-accommodated grain-boundary sliding in the geological literature (Hirth and Kohlstedt, 1995; Hansen et al., 2011). In contrast, Lifshitz sliding is coupled to vacancy diffusion along stress gradients during Nabarro-Herring or Coble diffusion creep. GBS is an essential process that contributes to superplasticity, which is the ability of a material to deform to strains on the order of $1000 \%$ without failure (Langdon, 2006; Komura et al., 2001). The term superplasticity does not indicate a deformation mechanism but is a phenomenological description. In experiments on metals (Langdon, 2006) and calcite (Schmid et al., 1977; Rutter et al., 1994) superplastic behaviour is most 
pronounced in a regime in which strain rate is proportional to approximately the square of both stress and grain size. This mechanical behaviour is associated with Rachinger sliding in materials with grains that are generally too small to host subgrain boundaries (Langdon, 2006). An important consideration for seismogenic faults is that experiments by Komura et al. (2001) on metals demonstrate a strong strain-rate dependence for superplasticity, where strain rates $>1 \mathrm{~s}^{-1}$ reduce the achievable strain from $1000 \%$ down to $100 \%$. This observation presents a challenge to the interpretation of superplastic behaviour from micro-, or nanostructures in the high-strain rate context of co-seismically produced materials.

In many metals, GBS is proposed as a deformation mechanism of nanogranular materials. The in-situ TEM deformation study by Kumar et al. (2003) on nanograined $\mathrm{Ni}$ with grain sizes $<30 \mathrm{~nm}$ revealed that GBS can be an important deformation mechanism even at room temperature. Those authors report the involvement of dislocations during the deformation process and emphasize the dominant role of dislocation-mediated plasticity. Experimental evidence suggests that at grain sizes of $<20 \mathrm{~nm}$ the material strength decreases and produces an inverse Hall-Petch effect (Kumar et al., 2003). Another study by Lu et al. (2000) also indicates that GBS may be significant in nanomaterials at lower homologous temperatures. At grain sizes below $10 \mathrm{~nm}$, dislocation activity ceases and GBS dominates. Whether in situ nanoscale deformation behaviour within a TEM can be generalised to be representative of bulk deformation behaviour remains a matter of debate (Ma, 2004). Nevertheless, deformation of materials with grain sizes $\gtrsim 30 \mathrm{~nm}$ that involves GBS can also involve dislocation activity. The combination of dislocations we observe (Figs. 4 \& 5), subgrain boundaries in EBSD (Figs. 2 \& 3), and the nanoscale CPO consistent with the activity of known slip systems (Figure 6) suggests that dislocation activity plays an important role during the formation and deformation of the nanostructure.

A mechanism that combines GBS and dislocation activity is disGBS and has been proposed as a deformation mechanism for several minerals, including calcite (Walker et al., 1990), olivine (Hirth and Kohlstedt, 1995; Hansen et al., 2011), and quartz (Tokle et al., 2019). Based on the microstructures and mechanical data from their experiments on olivine, Hansen et al. (2011) propose a similar disGBS mechanism to the model by Langdon (2006), in which the subgrain size is smaller than the grain size. Dislocation activity during disGBS may be an explanation for the CPO observed by Hansen et al. (2011) and may be an alternative interpretation to 
crystal plasticity for the micro- and nanostructure observed here. Schmid et al. (1977) and Walker et al. (1990) observed displacements across grain boundaries on the precut surfaces of split cylinders deformed in regimes with non-linear stress dependencies. Rutter et al. (1994) use the similarities of stress and grain-size exponents which fit with the later proposed model by Langdon (2006). Likewise, several studies (e.g., Schmid et al., 1977; Walker et al., 1990; Rutter et al., 1994) have measured regimes in which the stress and grain-size exponents of calcite are broadly in agreement with the models of disGBS reviewed by Langdon (2006). Rutter et al., (1994) report a CPO apparently formed during high-temperature creep deformation, where one of the experiments reached a strain of $600-1000 \%$, representing superplastic flow. Those authors interpreted their results to indicate a contribution from intracrystalline plastic flow involving cyclic dynamic recrystallisation but did not exclude the contribution of GBS.

High-strain torsion experiments $(\gamma=20)$ by Barnhoorn et al. (2005), however, demonstrate that post-deformational annealing can change the microstructural appearance and produce a foam structure where the grain morphologies are indistinguishable from a GBS microstructure. The CPO formed during initial deformation is enhanced with progressive annealing as the axis distributions become tighter. In addition, the calcite deformed by Barnhoorn et al. (2005) has microstructural characteristics indicating incomplete reworking of the starting material used and shares similarities with our microstructure (Fig. 2). Specifically, the slightly lobate grain boundaries and not ideal triple junctions of the foam microstructure are comparable. These similarities and a pronounced CPO across different scales suggest that the microstructures of the studied carbonate faults may be influenced by other deformation processes e.g., crystal plasticity, than exclusively GBS.

\subsubsection{Crystal plasticity}

The occurrence of CPOs suggests the activation of one or more slip systems in both Greek faults. Multi-scale analysis of crystal orientations (Figs. 2, 3 and 6) reveals that the CPO present at the nanoscale in the PSZ is also present in the adjacent cataclasite. The distributions of (0001) planes and $<\overline{1} 2 \overline{1} 0>$ axes from the Arkitsa fault are consistent with CPOs present in previous carbonates experimentally deformed under both seismic and sub-seismic conditions (Smith et al., 2013; Verberne et al., 2013; Kim et al., 2018; Demurtas et al., 2019; Pozzi et al., 2019). 
However, the experimental studies have not yet provided detailed slip-system analyses. The combined evidence of calcite (0001) planes aligned parallel to the slip plane, $<\overline{1} 2 \overline{1} 0>$ axes aligned parallel to the slip direction and the distribution of subgrain-misorientation rotation axes indicates the activation of the $(0001)<\overline{1} 2 \overline{1} 0>$ glide system (Figure $2 \mathrm{~d}$ and e). Subgrain-boundary misorientation axes (Figure 2e) parallel [0001] are consistent with the presence of twist boundaries parallel to the (0001) plane and consisting of $\langle\overline{1} 2 \overline{1} 0>$ screw dislocations whilst misorientation axes around $\langle 10 \overline{1} 0\rangle$ are consistent with the presence of tilt boundaries consisting of $(0001)<\overline{1} 2 \overline{1} 0>$ edge dislocations. Both types of boundaries can be produced by activation of the $(0001)<\overline{2} 2 \overline{1} 0>$ glide system. We note that the ring pattern in the centre of the $\langle\overline{1} 2 \overline{1} 0>$ pole figure (Figure 6c) is likely an artefact arising from diffraction pattern indexing during ACOM-TEM analysis. De Bresser and Spiers (1997) performed a detailed experimental study on calcite single crystals, in which they identified slip systems based on analysis of the traces of slip bands. In their experiments, the $(0001)<\overline{1} 2 \overline{1} 0>$ slip system was activated in the temperature range of $600-800^{\circ} \mathrm{C}$.

In contrast to the Arkitsa fault, misorientation axes of subgrain boundaries in the Schinos fault are dominantly parallel to $\langle\overline{1} 2 \overline{1} 0>$, with only secondary maxima parallel to $<10 \overline{1} 0>$ and [0001] (Fig. 3). Misorientation axes parallel to $<\overline{1} 2 \overline{1} 0>$ indicate the presence of subgrain boundaries consisting of edge dislocations on the $f\{\overline{1} 012\}<10 \overline{1} 1>$ or $r\{10 \overline{1} 4\}<\overline{2} 021>$ slip systems. In the experiments of (De Bresser and Spiers, 1997) the $f\{\overline{1} 012\}<10 \overline{1} 1>$ slip system was activated at temperatures between $600-800{ }^{\circ} \mathrm{C}$, while $\{r\}$ slip was activated over a broader temperature range of 300$800{ }^{\circ} \mathrm{C}$. These two slip systems also exhibit different critical resolved shear stress (CRSS). At temperatures $>600^{\circ} \mathrm{C}$, the CRSS for $f<10 \overline{1} 1>$ is $<20 \mathrm{MPa}$ and for $r<\overline{2} 021>$ is $\leq 10 \mathrm{MPa}$. Overall, we suggest that the misorientation axes around $\langle\overline{1} 2 \overline{1} 0>$ (Figure $3 a$ and e) most likely originate from edge dislocations on the $r<\overline{2} 021>$ slip system as the $\mathrm{CPO}$ indicates that this system is more favourably aligned for slip than is the $f<10 \overline{1} 1>$ system. The change from rotation around $<a>$ to additional rotation around [0001] and $<\mathrm{m}>$ indicates the activation of more than one slip system, in particular the additional activation of $(0001)<\overline{1} 2 \overline{1} 0>$. The high temperatures indicated by the misorientation analyses are in agreement with our previous estimates for these faults of $600-800{ }^{\circ} \mathrm{C}$, but $<1000^{\circ} \mathrm{C}$, based on the degree of sp ${ }^{2}$ hybridisation of partlyhybridised amorphous carbon (Ohl et al., 2020). Whether or not the potential hightemperature signals are diagnostic for deformation at co-seismic velocities warrants 
further investigation. Because a systematic experimental study of slip systems in sub-seismic and seismically deformed carbonate fault rocks is lacking, more experiments are required to investigate potential differences in $\mathrm{CPOs}$, including between dry and wet environmental conditions.

To evaluate whether changes in slip systems indicate shear-heating induced temperature gradients, we analysed EBSD subsets over a range of distances from the PSS to test for systematic variation in the temperatures associated with the recorded slip systems (De Bresser and Spiers, 1997). We find that overall, the Arkitsa (Fig. 2a) and Schinos (Fig. 3a) fault rocks do not exhibit systematic changes in misorientation axes and hence slip systems or associated temperatures with distance from the PSZ. If the faults experienced seismic slip, a temperature gradient was not recorded. However, the Schinos fault does display a non-systematic variation in the intensities of misorientation-axes maxima parallel to $<\overline{1} 2 \overline{1} 0>$ and [0001], suggesting variation in the contributions of $r$-slip and (c)<a $>$. The underlying cause for these non-systematic changes in misorientation axes remains unknown and warrants further investigation. Nevertheless, if we can reliably apply the slip system-temperature correlations from De Bresser and Spiers (1997), the common feature of both faults is the high temperatures suggested by the activation of specific slip systems. However, we note that the experiments carried out by De Bresser and Spiers (1997) were performed at $3 \times 10^{-5} \mathrm{~s}^{-1}$ and extrapolation of the results to higher strain rates should be undertaken with caution.

Combined numerical models and deformation experiments by Demurtas et al. (2019) indicate that a temperature-increase of approximately $\Delta T=620^{\circ} \mathrm{C}$ decays to about $50{ }^{\circ} \mathrm{C}$ over a thermal diffusion distance of $2 \mathrm{~mm}$ inside carbonate fault gouge with 1 second. Assuming a single shear-heating event, the resulting temperature diffusion front could be captured as a change in activated slip systems and associated CPOs. However, the absence of differences in slip systems with decreasing temperature away from the PSS may suggest a later thermal overprint of the cataclasite by more than one event. Based on the microstructures in Fig. 4a, this overprint may lead to annealing of the microstructure and a loss of an apparent temperature diffusion profile. Consequently, the analysed cataclasite could contain several slip surfaces which are no longer discernible. The agreement between $\mathrm{CPO}$ and subgrain misorientations suggests that crystal plasticity was the main deformation process to produce the $\mathrm{CPO}$ rather than other, more exotic CPOformation mechanisms such as surface energy interactions (Toy et al., 2015) or 
coupled solution and growth (Power and Tullis, 1989). Overall, our results show that crystal plasticity played a role within the whole fault rock volume.

Water can have an influence on crystal-plastic deformation. It is known for quartz that a higher water content can result in a transition of active slip systems from slip in the $<a>$ directions to slip in the [c] direction (Blacic, 1975) and a similar trend is observed by (Tokle et al., 2019) where added water can result in a different stress exponent. The temperature threshold for the transition between different dislocation creep regimes in quartz can also be lowered by about $100{ }^{\circ} \mathrm{C}$ by the addition of water (Hirth and Tullis, 1992). However, Stipp et al. (2002) point out that the regimes identified by Hirth and Tullis (1992) may correspond to different types of dynamic recrystallisation. The effect of water content on fabric transition is also known from experiments on olivine where for example type-B ((010)[001]) and typeC ((100)[001]) CPOs are more common with higher water content, whereas type-A $((010)[100])$ is most common without water (Jung and Karato, 2001). Deformation experiments on wet calcite at seismic velocities show a more significant drop in friction coefficient compared to dry experiments (e.g., Violay et al., 2014; Chen et al., 2017) and the development of a similar CPO to the one reported here (Demurtas et al., 2019). It has been inferred that the presence of water can promote hydrolytic weakening and influence dislocation glide and climb in calcite (Liu et al., 2002). We speculate that the above-mentioned examples of water influencing crystal-plastic deformation may also have an influence on the activity of specific glide systems and its activation temperature in crustal carbonate faults. The addition of water could explain why De Bresser and Spiers (1997) consider the (c)<a> slip system to be of minor importance in their experiments, which are performed dry and at low strain rates. The potential influence of water on crystal-plastic deformation suggests that the proposed temperature range for the activation of $(\mathrm{c})<\mathrm{a}>\left(600-800{ }^{\circ} \mathrm{C}\right)$ and $r$-slip $\left(300-800{ }^{\circ} \mathrm{C}\right.$ ) may be different or lower in other situations and may explain the absence of a temperature gradient in Figure 2 and 3: essentially no temperature gradient was produced. In such a case, the syn-deformational temperature would evolve along the water-vapour transition as suggested by Chen et al. (2017).

The development of CPOs has been reported in natural carbonate faults before. For example, Smith et al. (2013) and Kim et al. (2018) report a similar CPO and Kim et al. (2018) speculate about the contribution of crystal plasticity during deformation. Our subgrain misorientation analysis matches the inverse pole figures presented by displaying a rotational maximum around [0001] close to the slip 
surface (Kim et al., 2018). The authors report that the intensity of the maximum weakens over $10 \mathrm{~cm}$ away from the slip surface. This may indicate that temperature is not the main governing factor for the activation of the $(c)<a>$ glide system because temperature diffusion would reach background values after about $2 \mathrm{~mm}$ (Demurtas et al., 2019). In contrast to the fault rocks of Kim et al., (2018), our analyses do not show a pronounced region of plastic deformation. In addition, high dislocation densities are reported from numerous studies of natural faults, e.g. (Collettini et al., 2014) who also shows free dislocations, as well as nanometric, dislocation-free subgrains comparable to our observations in Figure 5.

\subsubsection{Deformation mechanism maps}

In the following, we compare our microstructural observations and interpretations of deformation mechanisms with theoretical considerations. We constructed deformation-mechanism maps (DMMs) (Fig. 8) (Ashby, 1972) for both the approximate ambient temperature conditions of $300^{\circ} \mathrm{C}$ during the inter-seismic period and onset of slip at a depth of 3-5 km and the potential high-temperature conditions of $600{ }^{\circ} \mathrm{C}$ attained by seismic shear heating, constrained by the observed CPO and $\mathrm{sp}^{2}$ hybridisation of partly-hybridised amorphous carbon (Ohl et al., 2020). The general parameters utilised are $A$ as a material-dependent factor, $n$ as the stress exponent, $p$ as the grain-size exponent, $B$ as a temperature-dependent constant and $Q$ as the activation energy. For the flow laws in Figure 8 we utilised the values $A=$ $10^{7.63}, n=1.1, p=3.3, Q=200 \mathrm{~kJ} \mathrm{~mol}^{-1}$ for diffusion creep (Herwegh et al., 2003); $A=$ $10^{4.93}, n=1.67, p=1.87, Q=190 \mathrm{~kJ} \mathrm{~mol}^{-1}$ for disGBS (Walker et al., 1990) and for crossslip-controlled plasticity we used a power law approximation with $A=10^{16.65}, B=$ 2.431 and $Q=584 \mathrm{~kJ} \mathrm{~mol}^{-1}$ according to Verberne et al., (2015), based on the initial work by De Bresser (2002). As a first approximation, we only consider flow laws for materials with grain sizes on the order of $10^{-8}-10^{-3} \mathrm{~m}$, comparable to the grain sizes of our faults. We also investigated a flow law derived for water-assisted grainboundary diffusion described by Verberne et al. (2019) and found that it produced the same slope of strain rate contours but predicted lower strain rates than the flow law by Herwegh et al., (2003). Hence, we include the flow law by Herwegh et al., (2003) because it is more reasonable for a high-strain rate environment. Future investigations will also need to determine the impact of flaw laws explicitly derived for nanogranular materials (Mohamed, 2011). 

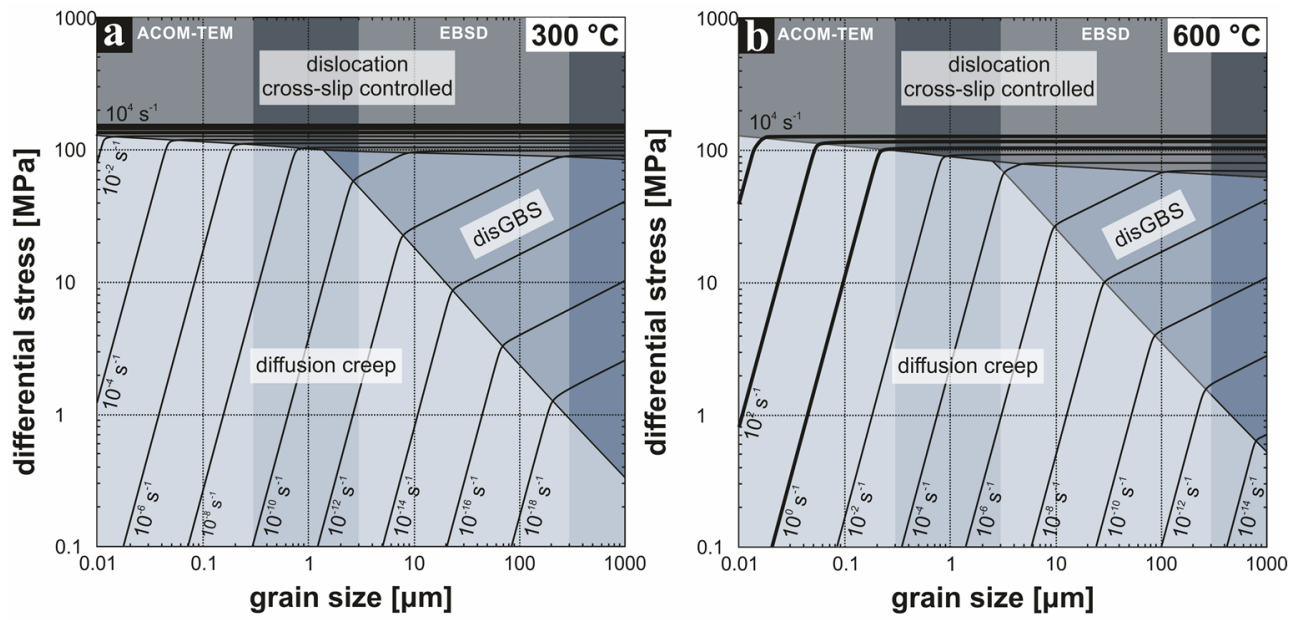

Figure 8: (previous page) Deformation-mechanism maps for calcite at (a and c) $600{ }^{\circ} \mathrm{C}$ and (e and d) $300{ }^{\circ} \mathrm{C}$. Light-shaded areas indicate the grain-size ranges from crystal orientation mapping by ACOM-TEM and EBSD. $\underline{a}$ and b: Deformation mechanism maps with three domains: diffusion creep (Herwegh et al., 2003), disGBS (Walker et al., 1990) and cross-slip controlled dislocation glide (De Bresser, 2002). Bold lines represent relevant strain rates.

Figure 8 displays DMMs calculated for temperatures of $300{ }^{\circ} \mathrm{C}$ and $600{ }^{\circ} \mathrm{C}$ representing the onset of seismic slip and potential peak deformation conditions, respectively. The difference in temperature has little influence on the position of the field boundaries but has a significant impact on the predicted strain rates. The constraints on the grain sizes in this study are good, but we lack reliable estimates of the stresses. At lower stresses, $\lesssim 100 \mathrm{MPa}$, more typical of shallow faults (e.g., Behr and Platt, 2014) the material is predicted to deform by diffusion creep and/or disGBS, depending on grain size. Close to a field boundary, dislocation activity may contribute to the total strain even within the diffusion creep field. Figure 8a suggests that at strain rates of $>1 \mathrm{~s}^{-1}$ and a temperature of $300{ }^{\circ} \mathrm{C}$, approximating the onset of seismic slip, calcite would deform by cross-slip controlled dislocation glide. Figure $8 \mathrm{~b}$ indicates that at $600{ }^{\circ} \mathrm{C}$ diffusion creep following the flow law of (Herwegh et al., 2003) can accommodate a strain rate of $>1 \mathrm{~s}^{-1}$, in material with grain sizes of $<100$ $\mathrm{nm}$ at stresses $<10 \mathrm{MPa}$. At $600{ }^{\circ} \mathrm{C}$, coseismic strain rates $\left(1-10^{4} \mathrm{~s}^{-1}\right)$ can be accommodated in the PSS by either diffusion creep or plasticity depending on the differential stress. In general, the DMMs predict that seismic strain rates could be accommodated by cross-slip-controlled dislocation glide at stresses $>100 \mathrm{MPa}$.

We have shown that crystal-plasticity played a role during the deformation of fault rocks within the vicinity of principal slip surfaces. Although the DMMs in Figure 8 predict the operation of deformation mechanisms known to not produce a 
strong CPO, our micro-, and nanostructural observations indicate the activation of several slip systems resulting in CPO development. Future studies need to further evaluate the competition between crystal plasticity and GBS processes during the seismic cycle. Advances may be made by combining microstructural observations and DMMs as we have, and by considering dynamic coseismic changes of different deformation mechanisms.

\subsubsection{Rheological considerations}

\subsubsection{Piezometric equilibrium and dynamic recrystallisation}

The analysis above indicates that crystal plasticity and recrystallisation are feasible even under upper-crustal conditions in the brittle regime. Nevertheless, crystal plasticity and GBS processes will be cooperating mechanisms during fault rock deformation. To further decipher the physical nature behind co-seismic deformation processes, Pozzi et al., (2019) proposed the establishment of a piezometric equilibrium during dynamic recrystallisation between GSI and GSS deformation mechanisms. The authors propose that this equilibrium promotes rheological weakening during seismic slip due to cycles of grain-size reduction and thermally driven grain growth. We can further assess the piezometric relationship for recrystallised calcite grains with the relation proposed by Platt and De Bresser (2017):

$$
D=K \sigma^{-p}
$$

where $D$ is the recrystallised grain size in $\mu \mathrm{m}, K=1243, \sigma$ is the differential stress in $\mathrm{MPa}$, and $p=1.09$. For the cataclasite region with grain sizes of approximately $5-2$ $\mu \mathrm{m}$, Eqn. 3 predicts differential stresses in the range 158-365 $\mathrm{MPa}$. This range of differential stress would plot inside the field of dislocation cross-slip controlled deformation in Figure 8, regardless of grain size, and suggests that crystal plasticity was the major contributor to accommodate strain. For the foam nanostructure (Fig. 6) with grain sizes of approximately 200-20 nm, Eqn. 3 predicts differential stresses in the range 3-24 GPa. While the differential stresses for the cataclasite are plausible on a fault plane, the potential differential stresses estimated for the foam nanostructure are implausibly high and demonstrate that the piezometric relationship of Platt and De Bresser (2017), which was calibrated for much coarser grain sizes, is not applicable in this context. Either the piezometric relationship has a different slope at these finer grain sizes or the nanograins formed by mechanisms 
other than dynamic recrystallisation. In such a case, static recrystallisation may be able to reach such small grain sizes as a formation mechanism for nanograins and would not reflect differential stresses during deformation.

\subsubsection{Post-seismic annealing and fault rock strength}

Our observations of the grain-boundary morphology within the Arkitsa nanostructure (Fig. 4c) suggest that post-seismic annealing occurred via static recrystallization and grain growth through grain-boundary migration. We define two foam nanostructures, old and new, depending on the overprinting relationship. The older foam nanostructure lies at a greater distance from the PSS (Fig. 4c, white circle), while the new foam nanostructure borders the PSS (Fig. 4c, black circles). We interpret apparent traces of discontinuities that displace grains (Fig. 4c) as fracture planes originating from the PSS. These fractures cross-cut grains of the interlocked nanostructure overprinting the old foam structure (Fig. 4c). Larger grains within the old foam nanostructure (Fig. 4c, white circle) are truncated by fractures that cannot be traced back to the PSS but terminate within the new foam nanostructure (Fig. 4c, black circle), instead. The resulting cross-cutting relationships suggest fault reactivation after static recrystallisation. Angular relations indicate that the fractures are Riedel shears (Verberne et al., 2013) and suggest that slip along the PSS may have also taken place during an advanced stage of nanostructural evolution.

To assess the influence of grain size on the strength of the PSZ, we calculate the required minimum shear stress, $\sigma_{\mathrm{s}}$, to fracture a grain of size $d[\mathrm{~m}]$ using a modified Hall-Petch equation (Sammis and Ben-Zion, 2008):

$$
\sigma_{s}=Y / 2=\frac{2 C K_{I c}}{\sqrt{d}}
$$

where $C=\sqrt{\frac{2}{3}}$ and $K_{I C}=0.39 \mathrm{MPa} \sqrt{\mathrm{m}}$ (calcite, Broz et al., 2006). For grain sizes of approximately 5-2 $\mu \mathrm{m}$, Eqn. 4 predicts minimum shear stresses in the range 285-450 $\mathrm{MPa}$. For the median grain size of $21 \mathrm{~nm}$ from ACOM-TEM, Eqn. 4 predicts a minimum shear stress of $4.4 \mathrm{GPa}$. Given the spread of the grain-size distribution, we also determine $\sigma_{s}$ for a grain size of $200 \mathrm{~nm}$ (Figure 6a and b) and obtain 1.4 GPa. Based on these calculations, it is evident that with decreasing grain size, slip localization onto the PSS increases because the required shear stress to fracture grains increases. A potential explanation is the decreasing distance between dislocation pinning points leading to a grain-size dependant increase in yield stress with decreasing grain diameter (Kato et al., 2008). The modified Hall-Petch equation, 
which we note is derived from fitting empirical data from $\mathrm{Al}_{2} \mathrm{O}_{3}$ spheres and uses an empirically derived value for $K_{I c}$ from microindentation, should be applied with caution. Alternatively, either local grain-scale stresses may be higher than the overall average stress state of the fault during slip or fractures develop preferentially along zones of weakness, such as cleavage and twin planes.

The localisation of slip can be observed over six orders of magnitude ( $\mu \mathrm{m}-$ $\mathrm{m}$ ) and suggests a repeated toughening of the microstructure by grain-boundary strengthening. Our microstructural observations coupled to DMM predictions suggest that at small grain sizes diffusion creep and dislocation creep were active. Deformation by GBS would result in stretching and elongation of the host-rock clasts (Figure 2a and 3a) but the initial shape of the fragments is preserved despite showing an internal, polygonal structure expected to promote GBS. This example is further illustrated by another clast in a transition stage consisting half of a fine-grained microstructure and half of a single crystal (Fig. 2a, white lasso). These examples show that the internal structure is not diagnostic for GBS. Grain-size reduction by deformation and annealing suggests that with evolving localisation, the fault plane becomes progressively stronger with every annealing step. This proposition supports the existence of a grain-boundary strengthening effect within the fault rock volume. Figure 1d shows the presence of a secondary slip surface which develops inside the Schinos cataclasite and we propose that its formation was the first microscale evidence for the locking of the fault rock volume immediately below the PSS. This interpretation is consistent with photographs of the fault exposures (Fig. $1 \mathrm{~b}$ and $\mathrm{d}$ ) that show various late-stage fault planes which crosscut inside the wider fault damage zone. Multiple slip surfaces like those typical in any fault zone may be the macroscopic expression of a repeated grain-boundary strengthening effect. Ultimately, the grain size along the fault plane may reach a critical limit, prompting the fault plane to jump and localise elsewhere inside the damage zone leading to the formation of multiple slip surfaces.

\subsection{Conclusion}

The subgrain misorientations and the matching crystallographic preferred orientations across different scales indicate that crystal plasticity played a role during fault rock formation in the Arkitsa and Schinos fault. Although the precise nature of slip systems at sub-seismic velocities are unknown, our results suggest that the slip systems inferred from subgrain misorientation analysis potentially indicate 
high temperatures during co-seismic deformation or the influence of water. Nevertheless, future studies need to further evaluate the applicability of slip-system analyses as paleoseismicity indicators, especially comparing dry and wet deformation. Plastic straining and tempering, described as cold working and annealing, offers an alternative mechanism to produce a cohesive nanogranular material. Paleopiezometric estimations based on grain sizes immediately below the slip surface suggest that either dynamic recrystallization did not take place or at least did not follow the piezometer calibrated by low-strain rate experiments. The cyclic repetition of plastic strain, annealing and static recrystallization via grain-boundary migration produces a grain-boundary strengthening effect until the grain size reaches a critical minimum. This strengthening effect forces the fault plane to relocate inside the fault damage zone, resetting the deformation cycle.

\section{Acknowledgements}

This study was funded by the Dutch research organisation (NWO) with the project number ALWOP.2015.082. O.P. is supported by an ERC starting grant "nanoEARTH" (852069). The authors also thank Edgar Rauch for discussion and input regarding ACOM-TEM, A. Niemeijer, E. Korkolis and J.H.P. De Bresser for discussions and I. Koukouvelas for the outcrop locations. The TEM facility in Lille (France) is supported by the Conseil Regional du Nord-Pas de Calais, and the European Regional Development Fund (ERDF). All datasets found in this manuscript will be made available open access through the European Plate Observing System at https://public.yoda.uu.nl/geo/UU01/A77O7X.html. 


\section{Supplementary material}

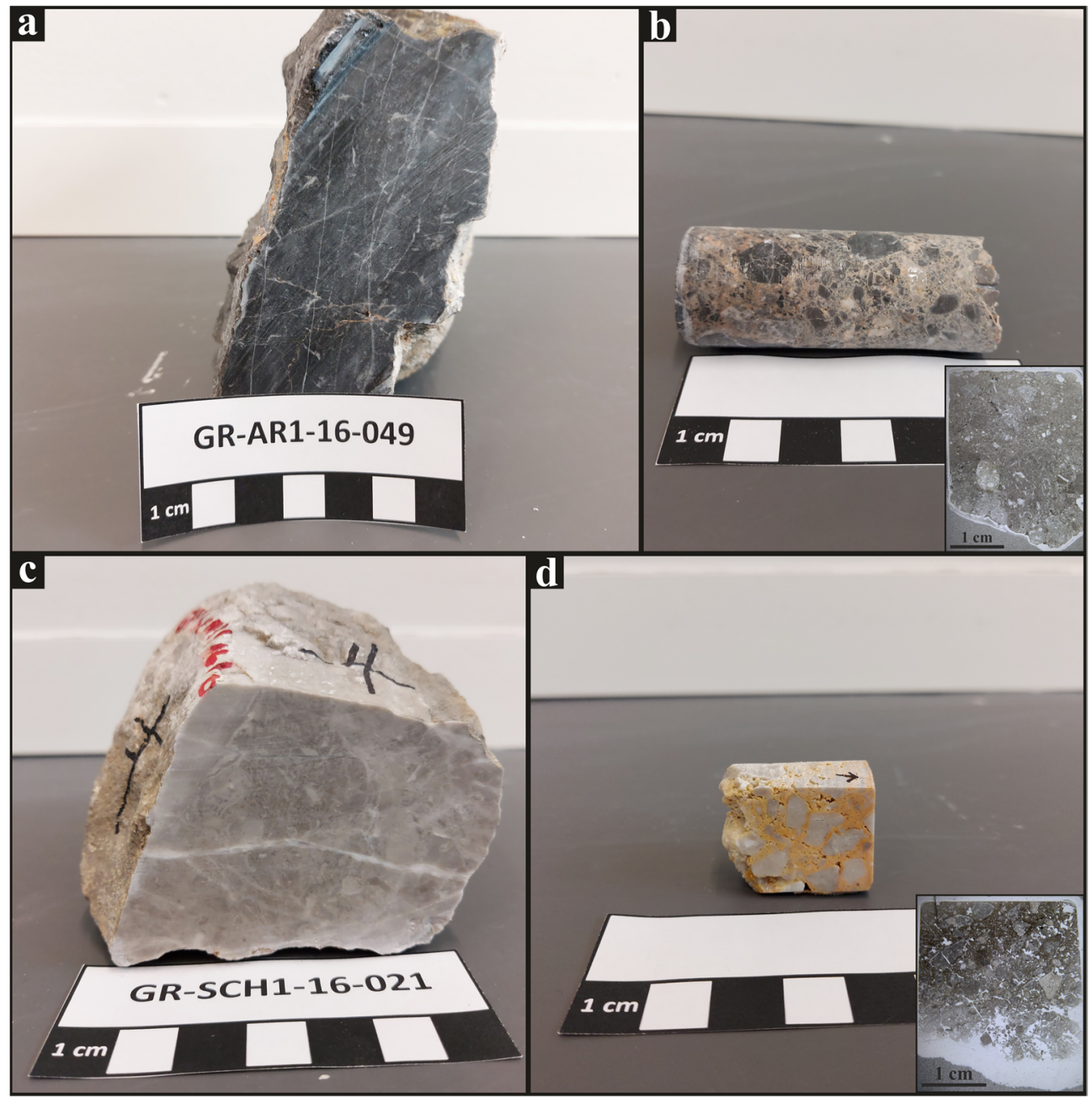

Figure S1. Overview of hand specimen. $\underline{a}$ : Hand specimen photo of undeformed Arkitsa host-rock carbonate. $\underline{b}$ : Photo of drill core from the Arkitsa footwall cataclasite. Principal slip surface located at the left edge of the drill core. Inset: Plane-polarised thin section image. $\underline{\text { : }}$ Hand specimen photo of undeformed Schinos host-rock carbonate. $\underline{\text { d: }}$ Photo of drill core from the Schinos footwall cataclasite. Principal slip surface located at the right edge of the drill core. Inset: Plane-polarised thin section image. 
Chapter 2: Crystal-plastic deformation in seismically active carbonate fault rocks

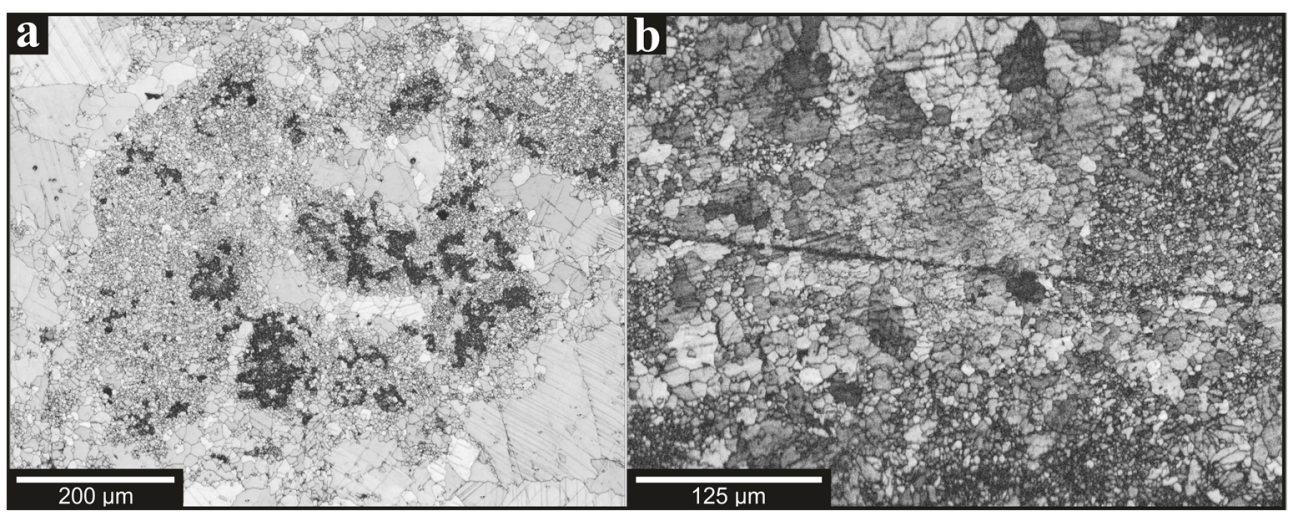

Figure S2. Electron backscatter band-contrast maps showing the host-rock microstructure of Arkitsa (a) and Schinos (b). 


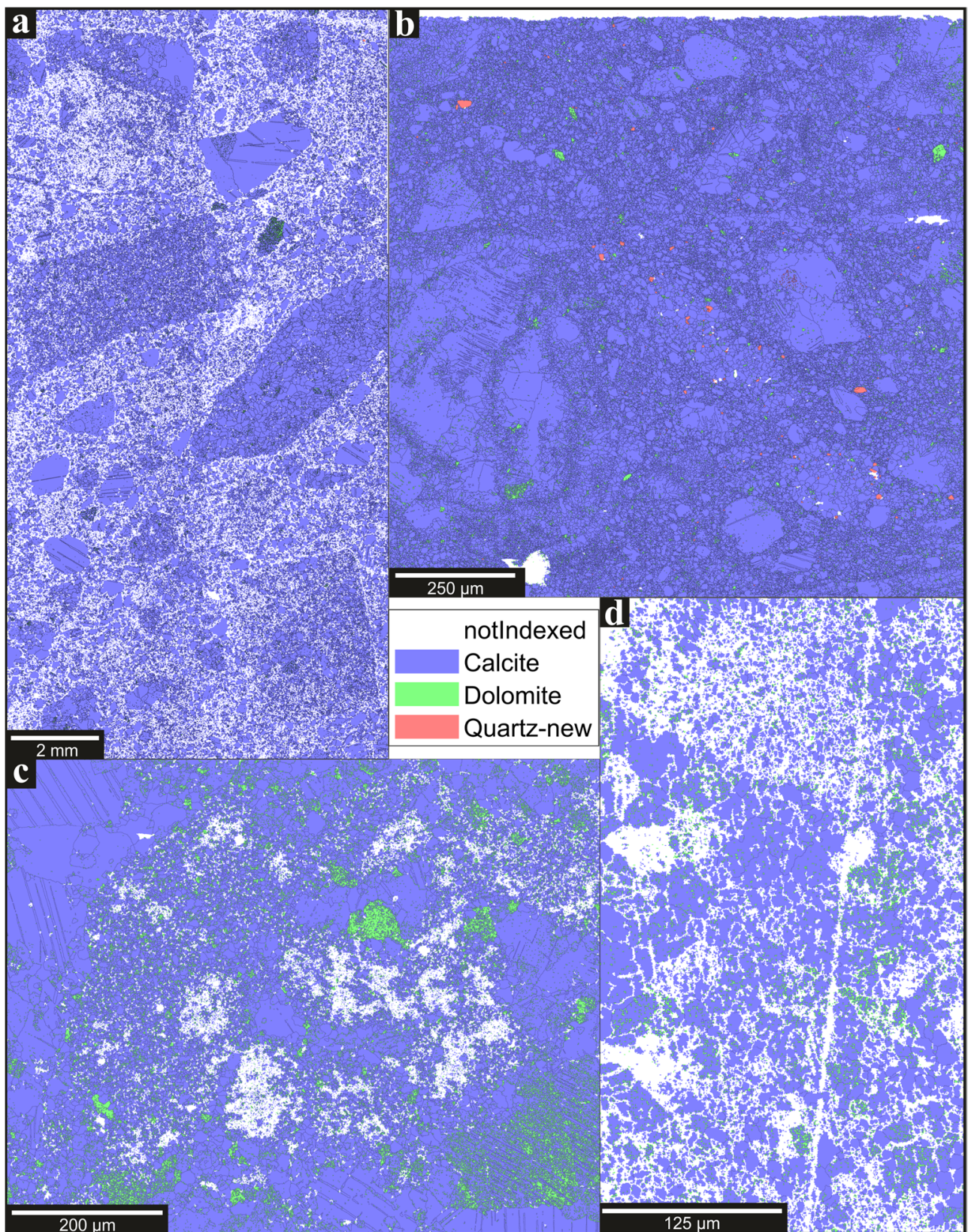

Figure S2. Phase maps created from electron backscatter diffraction. a: Phase map from EBSD map of the Arkitsa footwall cataclasite shown in Figure S2a. $\underline{\boldsymbol{b}}$ : Phase map from EBSD map of the Schinos footwall cataclasite shown in Figure S3a. c: Phase map from EBSD map of the Arkitsa host rock shown in Figure S2b. d: Phase map from EBSD map of the Schinos host rock shown in Figure S2b. 


\section{References}

Abe, S. and Mair, K., 2005. Grain fracture in 3D numerical simulations of granular shear. Geophysical Research Letters. 32.5, doi: 10.1029/2004GL022123.

Ambraseys, N. N. and Jackson, J. A., 1990. Seismicity and associated strain of central Greece between 1890 and 1988. Geophysical Journal International. 101.3, 663708, doi: 10.1111/j.1365-246x.1990.tb05577.x.

Ashby, M. F., 1972. A first report on deformation-mechanism maps. Acta Metallurgica. 20.7, 887-897, doi: 10.1016/0001-6160(72)90082-x.

Bachmann, F., Hielscher, R. and Schaeben, H., 2011. Grain detection from 2d and 3d EBSD data-Specification of the MTEX algorithm. Ultramicroscopy. 111.12, 1720-1733, doi: 10.1016/j.ultramic.2011.08.002.

Barnhoorn, A., Bystricky, M., Burlini, L., Kunze, K., 2005. Post-deformational annealing of calcite rocks. Tectonophysics. 403(1-4), 167-191, doi: 10.1016/j.tecto.2005.04.008.

Billi, A., 2010. Microtectonics of low-P low-T carbonate fault rocks. Journal of Structural Geology. 32, 1392-1402, doi: 10.1016/j.jsg.2009.05.007.

Billi, A. and Storti, F., 2004. Fractal distribution of particle size in carbonate cataclastic rocks from the core of a regional strike-slip fault zone. Tectonophysics. 384, 115-128, doi: 10.1016/j.tecto.2004.03.015.

Behr, W. M. and Platt, J. P., 2014. Brittle faults are weak, yet the ductile middle crust is strong: Implications for lithospheric mechanics. Geophysical Research Letters. 41.22, 8067-8075, doi: 10.1002/2014g1061349.

Blacic, J. D., 1975. Plastic-deformation mechanisms in quartz: The effect of water. Tectonophysics. 27.3, 271-294, doi: 10.1016/0040-1951(75)90021-9.

Blenkinsop, T. G., 1991. Cataclasis and processes of particle size reduction. Pure and Applied Geophysics. 136.1, 59-86, doi: 10.1007/bf00878888.

Broz, M. E., Cook, R. F., Whitney D. L, 2006. Microhardness, toughness, and modulus of Mohs scale minerals. American Mineralogist. 91.1, 135-142, doi: 10.2138/am.2006.1844.

Bürgmann, R. and Dresen, G., 2008. Rheology of the Lower Crust and Upper Mantle: Evidence from Rock Mechanics, Geodesy, and Field Observations. Annual Review of Earth and Planetary Sciences. 36, 531-567, doi: 10.1146/annurev.earth.36.031207.124326. 
Chen, J., Niemeijer, A., Yao, L., Ma, S., 2017. Water vaporization promotes coseismic fluid pressurization and buffers temperature rise. Geophysical Research Letters. 44, 2177-2185, doi: 10.1002/2016g1071932.

Collettini C., Carpenter B.M., Viti C., Cruciani F., Mollo S., Tesei T., Trippetta F., Valoroso L., Chiaraluce L., 2014. Fault structure and slip localization in carbonate-bearing normal faults: An example from the Northern Apennines of Italy. Journal of Structural Geology. 67, 154-166, doi: 10.1016/j.jsg.2014.07.017.

Collier R.E., Pantosti D., D'addezio G., De Martini P.M., Masana E., Sakellariou D., 1998. Paleoseismicity of the 1981 Corinth earthquake fault: Seismic contribution to extensional strain in central Greece and implications for seismic hazard. Journal of Geophysical Research: Solid Earth. 103, B12. 30001-30019, doi: 10.1029/98JB02643.

Covey-Crump, S. J., 1997. The normal grain growth behaviour of nominally pure calcitic aggregates. Contributions to Mineralogy and Petrology. 129.2-3, 239254, doi: 10.1007/s004100050335.

De Bresser, J. H. P., 2002. On the mechanism of dislocation creep of calcite at high temperature: Inferences from experimentally measured pressure sensitivity and strain rate sensitivity of flow stress. Journal of Geophysical Research: Solid Earth. 107.2 B12, ECV 4, doi: 10.1029/2002jb001812.

De Bresser, J. H. P. and Spiers, C. J., 1997. Strength characteristics of the r, f, and c slip systems in calcite. Tectonophysics. 272.1, 1-23, doi: 10.1016/S00401951(96)00273-9.

Delle Piane C., Piazolo S., Timms N.E., Luzin V., Saunders M., Bourdet J., Giwelli A., Ben Clennell M., Kong C., Rickard W.D., 2017. Generation of amorphous carbon and crystallographic texture during low-temperature subseismic slip in calcite fault gouge. Geology. 46, 163-166, doi: 10.1130/G39584.1.

Demurtas M., Smith S.A., Prior D.J., Spagnuolo E., Di Toro G., 2019. Development of crystallographic preferred orientation during cataclasis in low-temperature carbonate fault gouge. Journal of Structural Geology. 126, 37-50, doi: 10.1016/j.jsg.2019.04.015.

De Paola N., Holdsworth R.E., Viti C., Collettini C., Bullock R., 2015. Can grain size sensitive flow lubricate faults during the initial stages of earthquake propagation? Earth and Planetary Science Letters. 431, 48-58, doi: 10.1016/j.epsl.2015.09.002. 
Di Toro G., Han R., Hirose T., De Paola N., Nielsen S., Mizoguchi K., Ferri F., Cocco M., Shimamoto T., 2011. Fault lubrication during earthquakes. Nature. 471, 494, doi: 10.1038/nature09838.

Di Toro, G. and Pennacchioni, G., 2004. Superheated friction-induced melts in zoned pseudotachylytes within the Adamello tonalites (Italian Southern Alps). Journal of Structural Geology. 26, 1783-1801, doi: 10.1016/j.jsg.2004.03.001.

Druiventak, A., Matysiak, A., Renner, J., \& Trepmann, C. A., 2012. Kick-and-cook experiments on peridotite: simulating coseismic deformation and post-seismic creep. Terra Nova, doi: 10.1111/j.1365-3121.2011.01038.x

Ferraro, F., Grieco, D. S., Agosta, F., \& Prosser, G., 2018. Space-time evolution of cataclasis in carbonate fault zones. Journal of Structural Geology. 110, 45-64, doi: 10.1016/j.jsg.2018.02.007.

Hansen, L. N., Zimmerman, M. E. and Kohlstedt, D. L., 2011. Grain boundary sliding in San Carlos olivine: Flow law parameters and crystallographic-preferred orientation. Journal of Geophysical Research: Solid Earth. 116.B8, doi: 10.1029/2011jb008220.

Heilbronner, R. and Barrett, S., 2014. Fractal Grain Size Distributions. Image Analysis in Earth Sciences. Berlin, Heidelberg: Springer Berlin Heidelberg, pp. 225-249.

Herwegh, M., Xiao, X. and Evans, B., 2003. The effect of dissolved magnesium on diffusion creep in calcite. Earth and Planetary Science Letters. 212.3-4, 457-470, doi: 10.1016/s0012-821x(03)00284-x.

Hielscher, R. and Schaeben, H., 2008. A novel pole figure inversion method: specification of the MTEX algorithm. Journal of Applied Crystallography. 41.6, 1024-1037, doi: 10.1107/s0021889808030112.

Hirth, G. and Kohlstedt, D. L., 1995. Experimental constraints on the dynamics of the partially molten upper mantle: Deformation in the diffusion creep regime. Journal of Geophysical Research: Solid Earth. 100.B2, 1981-2001, doi: $10.1029 / 94 j b 02128$.

Hirth, G. and Tullis, J., 1992. Dislocation creep regimes in quartz aggregates. Journal of Structural Geology. 14.2, 145-159, doi: 10.1016/0191-8141(92)90053-y.

Hollandt, J., Hartmann, J., Struß, O., \& Gärtner, R., 2010. Industrial Applications of Radiation Thermometry. Experimental Methods in the Physical Sciences. Academic Press. 43, 1-56. 
Humphreys, F. J. and Hatherly, M. (2004) Recrystallization and Related Annealing Phenomena. Elsevier Science Ltd. 215-67.

Jung, H. and Karato, S., 2001. Water-induced fabric transitions in olivine. Science. 293.5534, 1460-1463, doi: 10.1126/science.1062235.

Kato, M., Fujii, T., Onaka, S., 2008. Dislocation bow-out model for yield stress of ultra-fine grained materials. Materials Transactions. 49, 1278-1283, doi: 10.2320/matertrans.MRA2008012.

Kaplanis A., Koukouvelas I., Xypolias P., Kokkalas S., 2013. Kinematics and ophiolite obduction in the Gerania and Helicon Mountains, central Greece. Tectonophysics. 595, 215-234, doi: 10.1016/j.tecto.2012.07.014.

Keulen, N., Heilbronner, R., Stünitz, H., Boullier, A. M., Ito, H., 2007. Grain size distributions of fault rocks: A comparison between experimentally and naturally deformed granitoids. Journal of Structural Geology. 29.8, 1282-1300, doi: 10.1016/j.jsg.2007.04.003.

Kim, S., Ree, J. H., Han, R., Kim, N., Jung, H., 2018. Fabric transition with dislocation creep of a carbonate fault zone in the brittle regime. Tectonophysics. 723, 107116, doi: 10.1016/j.tecto.2017.12.008.

Kokkalas S., Jones R.R., McCaffrey K., Clegg P., 2007. Quantitative fault analysis at Arkitsa, Central Greece, using terrestrial laser-scanning (LiDAR). Bulletin of the Geological Society of Greece. 37, 1-14.

Komura, S., Horita, Z., Furukawa, M., Nemoto, M., Langdon, T. G., 2001. An evaluation of the flow behavior during high strain rate superplasticity in an AlMg-Sc alloy. Metallurgical and Materials Transactions A. 32.3,707-716, doi: 10.1007/s11661-001-0087-9.

Kumar, K. S., Suresh, S., Chisholm, M. F., Horton, J. A., Wang, P., 2003. Deformation of electrodeposited nanocrystalline nickel. Acta Materialia. 51.2, 387-405, doi: 10.1016/s1359-6454(02)00421-4.

Lambrakis, N., Katsanou, K. and Siavalas, G., 2014. Chapter 3: Geothermal fields and thermal waters of Greece: an overview', in Baba, A., Bundschuh, J., and D., C. (eds) Geothermal Systems and Energy Resources: Turkey and Greece. CRC Press. 1, 25-45.

Langdon, T. G., 2006. Grain boundary sliding revisited: Developments in sliding over four decades. Journal of Materials Science. 41.3, 597-609, doi: 10.1007/s10853-006-6476-0. 
Larède, V., 2018. Thermal structure of the Aegean lithosphere from numerical modelling. M.Sc. Thesis. Department of Earthsciences, Utrecht University.

Limberger, J., Calcagno, P., Manzella, A., Trumpy, E., Boxem, T., Pluymaekers, M., van Wees, J., 2014. Assessing the prospective resource base for enhanced geothermal systems in Europe. Geothermal Energy Science. 2, 55-71, doi: 10.5194/gtes-2-55-2014.

Liu, J., Walter, J. M. and Weber, K., 2002. Fluid-enhanced low-temperature plasticity of calcite marble: Microstructures and mechanisms. Geology. 30.9, 787-790, doi:10.1130/0091-7613(2002)030<0787: FELTPO>2.0.CO;2.

Lu, L., Sui, M. L. and Lu, K., 2000. Superplastic extensibility of nanocrystalline copper at room temperature. Science, 287.5457, 1463-1466, doi: 10.1126/science.287.5457.1463.

Ma, E., 2004. Watching the nanograins roll. Science. 305.5684, 623-624, doi: 10.1126/science.1101589.

Matysiak, A. K. and Trepmann, C. A., 2012. Crystal-plastic deformation and recrystallization of peridotite controlled by the seismic cycle. Tectonophysics. 530-531, 111-127. doi: 10.1016/j.tecto.2011.11.029.

Mendrinos, D., Choropanitis, I., Polyzou, O., Karytsas, C., 2010. Exploring for geothermal resources in Greece. Geothermics. 39.1, 124-137, doi: 10.1016/j.geothermics.2009.11.002.

Metaxas, A., Varvarousis, G., Karydakis, G., Dotsika, E., Papanikolaou, G., 2010. Geothermic status of Thermopylae - Anthili area in Fthiotida prefecture. Bulletin of the Geological Society of Greece. 43.5, 22652273, doi: 10.12681/bgsg.11426.

Mohamed, F. A., 2011. Deformation mechanism maps for micro-grained, ultrafinegrained, and nano-grained materials. Materials Science and Engineering: A. 528.3, 1431-1435, doi: 10.1016/j.msea.2010.10.048.

Nielsen, S. (2017) From slow to fast faulting: recent challenges in earthquake fault mechanics. Philosophical transactions. Series A, Mathematical, physical, and engineering sciences, 375. doi: 10.1098/rsta.2016.0016.

Niemeijer, A., Di Toro, G., Griffith, W. A., Bistacchi, A., Smith, S. A., Nielsen, S., 2012. Inferring earthquake physics and chemistry using an integrated field and laboratory approach. Journal of Structural Geology. 39, 2-36, doi: 10.1016/j.jsg.2012.02.018. 
Ohl, M., Plümper, O., Chatzaras, V., Wallis, D., Vollmer, C., Drury, M., 2020. Mechanisms of fault mirror formation and fault healing in carbonate rocks. Earth and Planetary Science Letters. 530, doi: 10.1016/j.epsl.2019.115886.

Papachristou, M., Voudouris, K., Karakatsanis, S., D'Alessandro, W., \& Kyriakopoulos, K., 2014. Geological setting, geothermal conditions and hydrochemistry of south and southeastern Aegean geothermal systems. Baba, A., Bundschuh, J., and D., C., in Geothermal Systems and Energy Resources: Turkey and Greece 7. CRC Press. 1, 47-75.

Papoulis, D., Romiou, D., Kokkalas, S., \& Lampropoulou, P., 2013. Clay minerals from the Arkitsa fault gouge zone, in Central Greece, and implications for fluid flow. Bulletin of the Geological Society of Greece. 47.2, 616-624, doi: 10.12681/bgsg.11095.

Pieri, M., Burlini, L., Kunze, K., Stretton, I., Olgaard, D.L., 2001. Rheological and microstructural evolution of Carrara marble with high shear strain: results from high-temperature torsion experiments. Journal of Structural Geology. 23.9, 1393-1413, doi: 10.1016/s0191-8141(01)00006-2.

Platt, J. P. and De Bresser, J. H. P., 2017. Stress dependence of microstructures in experimentally deformed calcite. Journal of Structural Geology. 105, 80-87, doi: 10.1016/j.jsg.2017.10.012.

Power, W. L. and Tullis, T. E., 1989. The relationship between slickenside surfaces in fine-grained quartz and the seismic cycle. Journal of Structural Geology. 11.7, 879-893, doi: 10.1016/0191-8141(89)90105-3.

Pozzi, G., De Paola, N., Holdsworth, R. E., Bowen, L., Nielsen, S. B., Dempsey, E. D., 2019. Coseismic ultramylonites: An investigation of nanoscale viscous flow and fault weakening during seismic slip. Earth and Planetary Science Letters. 516, 164-175, doi: 10.1016/j.eps1.2019.03.042.

Rauch, E. F. and Véron, M., 2014. Automated crystal orientation and phase mapping in TEM. Materials Characterization. 98, 1-9. doi: 10.1016/j.matchar.2014.08.010.

Renner, J., Evans, B. and Siddiqi, G., 2002. Dislocation creep of calcite. Journal of Geophysical Research: Solid Earth. 107.B12, ECV-6, doi: 10.1029/2001jb001680.

Rice, J. R., 2006. Heating and weakening of faults during earthquake slip. Journal of Geophysical Research: Solid Earth. 111.B2, doi: 10.1029/2005jb004006.

Rutter, E. H., Casey, M. and Burlini, L., 1994. Preferred crystallographic orientation development during the plastic and superplastic flow of calcite rocks. Journal of Structural Geology.16.10, 1431-1446, doi: 10.1016/0191-8141(94)90007-8. 
Sammis, C.G., Osborne, R.H., Anderson, J.L., Banerdt, M., White, P., 1986. Selfsimilar cataclasis in the formation of fault gouge. Pure and Applied Geophysics. 124.1-2, 53-78, doi: 10.1007/bf00875719.

Sammis, C.G. and Ben-Zion, Y., 2008. Mechanics of grain-size reduction in fault zones. Journal of Geophysical Research, 113.B2, doi: 10.1029/2006JB004892.

Sammis, C., King, G. and Biegel, R., 1987. The kinematics of gouge deformation. Pure and Applied Geophysics. 125.5, 777-812, doi: 10.1007/bf00878033.

Schmid, S.M., Boland, J.N. and Paterson, M.S., 1977. Superplastic flow in finegrained limestone. Tectonophysics. 43.3-4, 257-291, doi: 10.1016/0040-1951(77)90120-2.

Scholz, C. H., 1988. The brittle-plastic transition and the depth of seismic faulting. Geologische Rundschau. 77.7, 319-328, doi: 10.1007/bf01848693.

Scholz, C. H., 1998. Earthquakes and friction laws. Nature. 391.6662, 37-42, doi: $10.1038 / 34097$.

Sibson, R., 1982. Fault zone models, heat flow, and the depth distribution of earthquakes in the continental crust of the United States. Bulletin of the Seismological Society of America. 72.1, 151-163.

Smith, S., Di Toro, G., Kim, S., Ree, J., Nielsen, S., Billi, A., Spiess, R., 2013. Coseismic recrystallization during shallow earthquake slip. Geology. 41, 63-66, doi:10.1130/g33588.1.

Stipp, M., Stünitz, H., Heilbronner, R., Schmid, S.M., 2002. The eastern Tonale fault zone: a "natural laboratory" for crystal-plastic deformation of quartz over a temperature range from 250 to $700^{\circ} \mathrm{C}$. Journal of Structural Geology. 24.12, 1861-1884, doi: 10.1016/s0191-8141(02)00035-4.

Thomson, S.N., Stöckhert, B. and Brix, M.R., 1998. Thermochronology of the highpressure metamorphic rocks of Crete, Greece: Implications for the speed of tectonic processes. Geology. 26.3, 259-262, doi: 10.1130/00917613(1998)026<0259:TOTHPM>2.3.CO;2.

Tokle, L., Hirth, G. and Behr, W.M., 2019. Flow laws and fabric transitions in wet quartzite. Earth and Planetary Science Letters, 505, 152-161, doi: 10.1016/j.epsl.2018.10.017.

Toy V.G., Mitchell T.M., Druiventak A., Wirth R., 2015. Crystallographic preferred orientations may develop in nanocrystalline materials on fault planes due to surface energy interactions. Geochemistry, Geophysics, Geosystems. 16, 25492563, doi: 10.1002/2015gc005857. 
Trepmann, C.A., Hsu, C., Hentschel, F., Döhler, K., Schneider, C., Wichmann, V., 2017. Recrystallization of quartz after low-temperature plasticity-The record of stress relaxation below the seismogenic zone. Journal of Structural Geology. 95, 77-92, doi: 10.1016/j.jsg.2016.12.004.

Trepmann, C. A. and Stöckhert, B., 2013. Short-wavelength undulatory extinction in quartz recording coseismic deformation in the middle crust-an experimental study. Solid Earth. 4, 263, doi: 10.5194/se-4-263-2013.

Verberne, B. A., de Bresser, J. H., Niemeijer, A. R., Spiers, C. J., de Winter, D. M., Plümper, O., 2013. Nanocrystalline slip zones in calcite fault gouge show intense crystallographic preferred orientation: Crystal plasticity at sub-seismic slip rates at $18-150{ }^{\circ} \mathrm{C}$. Geology. 41.8, 863-866, doi: 10.1130/g34279.1.

Verberne, B. A., Niemeijer, A. R., De Bresser, J. H., Spiers, C. J., 2015. Mechanical behavior and microstructure of simulated calcite fault gouge sheared at 20-600 ${ }^{\circ} \mathrm{C}$ : Implications for natural faults in limestones. Journal of Geophysical Research: Solid Earth. 120, 8169-8196, doi: 10.1002/2015JB012292.

Verberne, B. A., Plümper, O. and Spiers, C.J., 2019. Nanocrystalline Principal Slip Zones and Their Role in Controlling Crustal Fault Rheology. Minerals. 9.6, 328, doi: $10.3390 / \min 9060328$.

Violay, M., Nielsen, S., Gibert, B., Spagnuolo, E., Cavallo, A., Azais, P., Vinciguerra, S., Di Toro, G., 2014. Effect of water on the frictional behavior of cohesive rocks during earthquakes. Geology. 42, 27-30, doi: 10.1130/G34916.1.

Walker, A. N., Rutter, E. H. and Brodie, K. H., 1990. Experimental study of grainsize sensitive flow of synthetic, hot-pressed calcite rocks. Geological Society, London, Special Publications. 54.1, 259-284, doi: 10.1144/gsl.sp.1990.054.01.24. 
Chapter 3: Fluid-induced phase transformations explain weakening in crustal carbonate faults 


\section{Abstract}

Differences in fault weakening and deformation behaviour have been observed in past dry and wet sliding experiments of calcite fault gouges. These differences suggest more in-depth investigations of coseismic fluid-rock interactions in the crust. We conducted sub-seismic $\left(v=0.1 \mu \mathrm{m} / \mathrm{s}, \sigma_{n}=50 \mathrm{MPa}, T=92{ }^{\circ} \mathrm{C}\right)$ and seismic $\left(v=1 \mathrm{~m} / \mathrm{s}, \sigma_{n}=2\right.$ and $\left.4 \mathrm{MPa}\right)$ deformation experiments on pre-ground calcite fault gouge under dry and hydrous conditions. In these experiments we used $\mathrm{H}_{2}{ }^{18} \mathrm{O}$ as the pore fluid to track possible transient fluid-rock reactions during deformation processes. Incorporation of ${ }^{18} \mathrm{O}$ into small grains after the experiment was observed using two high-resolution secondary ion mass spectrometry techniques (Nanoscaleresolved secondary ion mass spectroscopy and Helium ion microscope secondary ion mass spectroscopy). The presence of ${ }^{18} \mathrm{O}$ within the calcite structure of these small grains was confirmed by Raman spectroscopy. The formation of entire grains of ${ }^{18} \mathrm{O}$-enriched calcite on the timescale of the experiments demonstrates that isotope exchange proceeds through the pore fluid rather than by solid-state transformation. We estimate that during seismic deformation about $65 \%$ of the deformed material reacts with the available pore fluid. Critically, the Raman spectroscopy analysis also highlights the formation of portlandite $\left(\mathrm{Ca}(\mathrm{OH})_{2}\right)$ and amorphous carbon. These reaction products indicate that calcite decarbonation occurs during deformation, the products of which $\left(\mathrm{CO}_{2(\mathrm{~g})}\right.$ and $\left.\mathrm{CaO}_{(\mathrm{s})}\right)$ back-react to form the new calcite grains. For isotope incorporation to occur during this reaction the $\mathrm{CO}_{2(\mathrm{~g})}$ must dissolve into the pore fluid and $\mathrm{CaO}$ should hydrate to form portlandite. Amorphous carbon likely

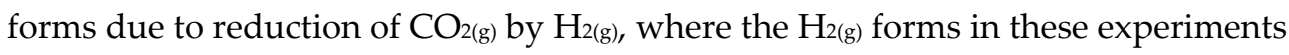
upon electrolysis of water via the build-up of an electric potential during calcite deformation. Because we observe amorphous carbon during both, low-, and highvelocity experiments, we propose that the reactions to form amorphous carbon are mainly stress-enhanced and chemically driven. Thus, they do not need a high amount of thermal energy input. Stable sliding during low-velocity deformation and slip weakening during high-velocity experiments point to a strain-rate dependent weakening mechanism. We hypothesise that a combination of amorphous carbon and pressurised volatiles reduces interparticle contacts, resulting in the breakdown of the load-bearing framework and leading to a fluidisation effect. Our research demonstrates that at the time of seismic deformation over $65 \%$ of the former calcite fault gouge is not deforming as calcite but forms a transient phase with calcite 
starting material and various non-crystalline phases. Our findings imply that seismic deformation of carbonate rocks under hydrous conditions involves transient phase changes that should be accounted for in earthquake models to improve predicting seismic behaviour of crustal carbonate faults.

\subsection{Introduction}

Crustal fault zones are known to act as permeable structures and major pathways for fluids (Caine et al., 1996; Scholz, 2019). As essential constituents of Earths' crust, unravelling the interplay between fluids and crystalline material during fluid-rock interactions is of great importance. The German continental deep drilling project, Kontinentale Tiefbohrung (KTB), shows that a volume of $460 \mathrm{~m}^{3}$ free fluids can be pumped from a depth of approx. $4000 \mathrm{~m}$ (Emmermann and Lauterjung, 1997), demonstrating that fluids are present in large quantities within the seismogenic zone. Consequently, fluids in the crust may play a critical role in changing or controlling deformation mechanisms in seismogenic crustal faults.

Experiments representing seismic carbonate deformation often report a sharp drop in friction coefficient considered as dynamic weakening (Han, et al., 2007a, 2007b; Spagnuolo et al., 2015; Chen et al., 2017; Demurtas et al., 2019), but the precise mechanism behind this behaviour remains enigmatic. Dynamic weakening is stronger in wet experiments illustrating that deciphering the physico-chemical interactions between fluids and fault-rock material is crucial. Microphysical models attempting to assess active deformation mechanisms during frictional sliding do not fully account for fluid-mediated effects and mostly focus on mechanical particle interactions, leaving the resulting physico-chemical changes unresolved (Scholz, 1998). Conversely, microphysical models like the Chen-Niemeijer-Spiers (CNS) model consider nanoscale-diffusion processes but are mostly focused on graincontact areas and low-velocity deformation rates (Chen and Spiers, 2016). It is the interaction on the nanoscale of granular fault materials with fluids that may drive changes in rheological behaviour but warrants extrapolation to higher strain rates. The involvement of fluids is mostly inferred from the identification of dissolution sites producing grain indentations, yet direct evidence of fluid-assisted deformation mechanisms operating in granular volumes is absent (Chen and Spiers, 2016).

Secondary phases, for example portlandite and amorphous carbon, are reported to form syn-deformational in several studies, but the formation mechanisms of these phases remain unclear (Han et al., 2007; Verberne, et al., 2014; 
Spagnuolo et al., 2015; Delle Piane et al., 2017). We suspect that the formation of weak phases is connected to reaction with fluids because the presence of portlandite has already been associated with lime hydration in Chapter 1 of this thesis. The resulting mechanistic and rheological changes of carbonates deforming under hydrous (wet) conditions and the formation of weak phases may, therefore, have a major impact on the seismic cycle, not only by facilitating slip, but also by contributing to fault healing.

By combining low velocity $(v=0.1 \mu \mathrm{m} / \mathrm{s})$ and high-velocity $(v=1 \mathrm{~m} / \mathrm{s})$ rockdeformation experiments with stable-isotope geochemistry, we gain unparalleled insights into how carbonate fault rocks deform at the micro-, and nanoscale. Because of the low natural abundance of the stable ${ }^{18} \mathrm{O}$ isotope $(0.2 \%$ (Lide, 2004)), we utilise $\mathrm{H}_{2}{ }^{18} \mathrm{O}$ pore fluid in this study as a novel, in-situ-tracer to resolve mineral reequilibration and transient processes during deformation. This approach enables us to identify transient fluid-rock interactions which would otherwise not be detectable in the final deformation product. Previous research studying carbonate-replacement reactions shows that the incorporation of the stable oxygen isotope ${ }^{18} \mathrm{O}$ into the calcite crystal structure results in new isotope combinations within the carbonate group (Perdikouri et al., 2011). Molecules, or molecular groups like the carbonate group of calcite, where atoms have been substituted by different isotopes are called isotopologues. In the case of the calcite-carbonate group, the isotopologues are detectable with Raman spectroscopy at $1086 \mathrm{~cm}^{-1},\left(\mathrm{C}^{16} \mathrm{O}^{2-}\right), 1065 \mathrm{~cm}^{-1}\left(\mathrm{C}^{16} \mathrm{O}_{2}{ }^{18} \mathrm{O}^{2-}\right)$, $1046 \mathrm{~cm}^{-1}\left(\mathrm{C}^{18} \mathrm{O}_{2}{ }^{16} \mathrm{O}^{2-}\right)$ and $1024 \mathrm{~cm}^{-1}\left(\mathrm{C}^{18} \mathrm{O}_{3^{2-}}\right)$ (Perdikouri et al., 2011). If the starting material or a deformation product from the low-, and high-velocity experiments interacts with the ${ }^{18} \mathrm{O}$-doped pore fluid, an isotope exchange between ${ }^{16} \mathrm{O}$ of the starting calcite and ${ }^{18} \mathrm{O}$ of the pore fluid may occur, providing evidence for newly formed material and the nature of phase transformations that occur.

Our results show that deformation-induced decarbonation, subsequent dissolution of the decarbonation products and subsequent reactions result in newly formed calcite grains containing ${ }^{18} \mathrm{O}$. The syn-deformational formation of amorphous carbon weakens the carbonate fault and leads to fluidisation and loss of grain contact. We propose that the transient reactions revealed via stable-isotope tracing affect the overall rheological behaviour of a carbonate fault gouge throughout the seismic cycle. 


\subsection{Methods and materials}

Deformation experiments were performed on calcite powder (pre-ground islandic spar, starting grain size $\approx 28 \mu \mathrm{m}$ ) as a fault-gouge analogue using a triaxial directshear shuttle vessel operated at low velocity (Utrecht University, The Netherlands) and a high-velocity friction apparatus (Chinese Earthquake Administration, Beijing).

\subsubsection{Deformation experiments and materials}

For the high-velocity experiments, the simulated fault gouge was placed between two Ti-alloy pistons, each of $4 \mathrm{~cm}$ diameter (Fig. 1a). One-gram deionised water or one-gram water enriched to 97 at $\% \mathrm{H}_{2}{ }^{18} \mathrm{O}$ (Sigma Aldrich) was added to the sample in the sample holder to fully saturate the sample. The pore fluids were added with a syringe as droplets on the top of the sample to achieve the best possible area coverage when wetting the samples. A Teflon sleeve was positioned on the outside, over both pistons to prevent sample-, and pore-fluid escape. This setup ensured that no pore fluid exchange could occur between the sample holder and the surroundings during the experiments. For comparison, an experiment without addition of pore fluid was run at room humidity. A thermocouple was embedded in the bottom piston at $2 / 3$ radius distance to continuously monitor temperature throughout the experiments (Fig. 1b). For more details about the high-velocity friction apparatus see Ma et al. (2014) and Chen et al. (2017). The top piston performed a sinistral rotation whilst the bottom piston remained stationary. All high-velocity experiments were pre-sheared for $1 \mathrm{~m}$ at $v=1 \mathrm{~mm} / \mathrm{s}$ to produce a relatively mature fault before imposing seismic slip. The slip-weakening distance was determined by least squares curve fitting using:

$$
\mu=\mu_{s s}+\left(\mu_{p}+\mu_{s s}\right) \exp \left(\log (0.05) d / D_{w}\right)
$$

where $\mu$ is the apparent friction coefficient, $\mu_{s s}$ the steady-state friction coefficient, $\mu_{p}$ the peak-friction coefficient, $d$ is the total displacement and $D_{w}$ the slip-weakening distance (Mizoguchi et al., 2007).

The high-velocity friction experiments were conducted at a slip rate of $v=1$ $\mathrm{m} / \mathrm{s}$ for a total displacement of $2 \mathrm{~m}$ and $20 \mathrm{~m}$ and normal stresses of $\sigma_{n}=2$ and $\sigma_{n}=4$ $\mathrm{MPa}$ (see Table 1). Friction was continuously monitored during the experiments and was corrected for Teflon sleeve friction. The change in layer thickness was continuously monitored during the experiments. This experimental setup resulted 
in a deformation time of $t_{\text {def }}=2$ and 20 seconds and total contact time of pore fluid and fault gouge, including mounting and unmounting, of approximately $t_{t o t}=20$ minutes.

Low-velocity direct-shear experiments were performed in a triaxial testing machine. The sample holder for the direct-shear experiment consists of two Lshaped, steel half-cylinders (Fig. 1c) with the simulated fault gouge situated on a 49 x $35 \mathrm{~mm}$ fine-fretted surface between the two half-cylinders (Fig. 1d). One millimetre of the simulated fault gouge was placed on one of the two half-cylinders and subsequently pressed with $\sim 4600 \mathrm{~kg}$ to ensure consolidation. One-gram deionised water or one-gram water enriched to $97 \mathrm{at} \% \mathrm{H}_{2}{ }^{18} \mathrm{O}$ (Sigma Aldrich) was then added to the sample in the sample holder using the same procedure conducted for the highvelocity friction experiments. No pore fluid exchange should occur between the sample holder and the surroundings during the experiments. The sample was then mounted with the opposite side of the half-cylinder and wrapped with a thermo-
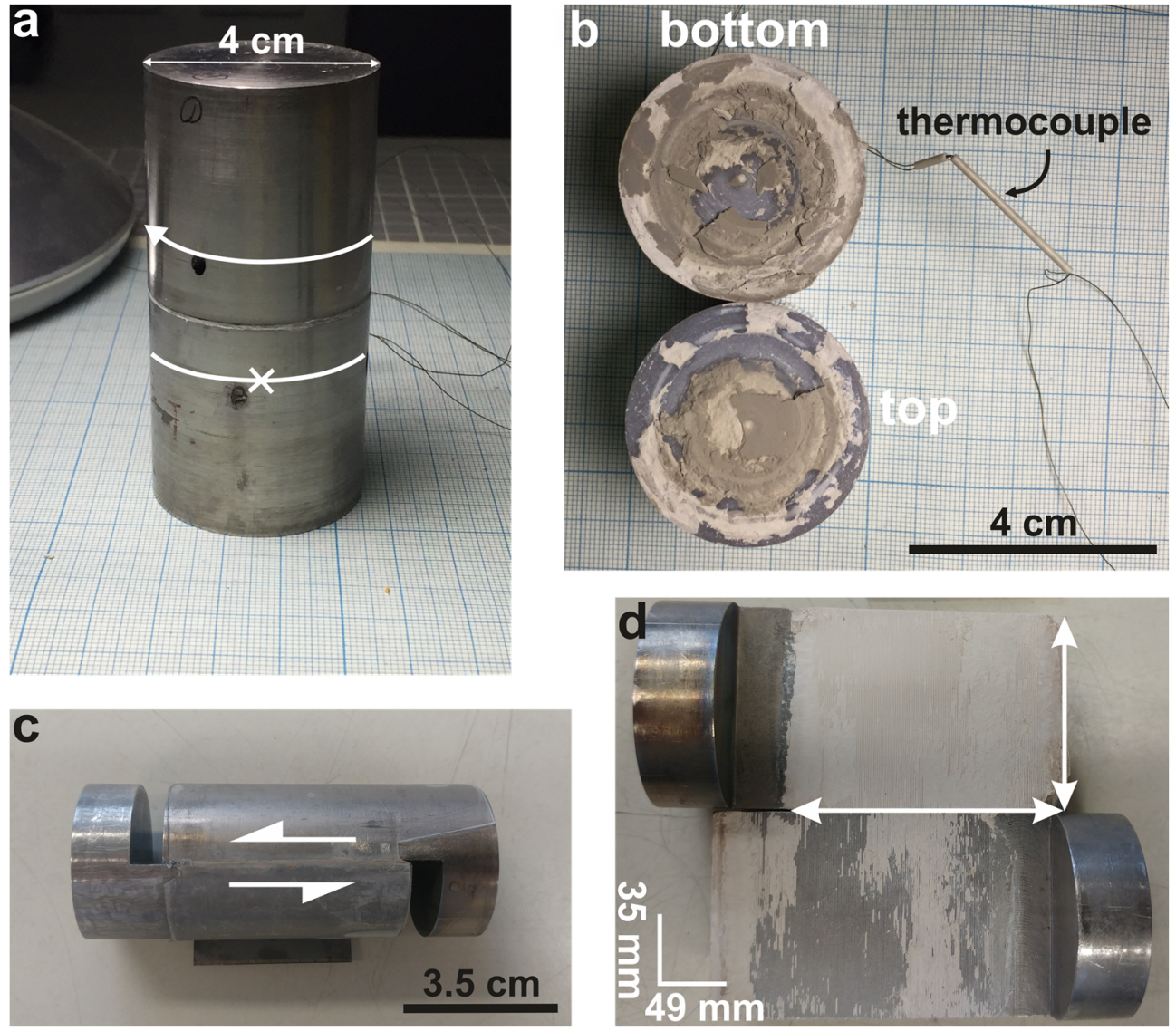
Figure 1: (previous page) Sample assembly of high-velocity experiments $(\boldsymbol{a}-\boldsymbol{b})$ and direct-shear experiments (cd). a: Mounted sample between two Ti-alloy pistons before experiment. $\underline{\boldsymbol{b}}$ : Unmounted sample post-mortem. Darker grey colour indicates that sample still contains fluid. $\underline{c}$ : Mounted sample between two L-shaped half-cylinders before experiment. Thermo-sensitive sleeve confines sample to the sides. $\mathrm{d}$ : Recovered sample post-mortem. Grooves of the fine-fretted counterpart are imprinted on the top surface.

sensitive sleeve which was heated with a blow dryer to ensure fit. Both gaps (see Fig. 1c) were filled with a solid silicon-rubber plug each and the whole assembly was wrapped with silicon foil to keep each component in place. The samples were sheared at $v=0.1 \mu \mathrm{m} / \mathrm{s}$ for a total displacement of $4.6 \mathrm{~mm}$, at $T=92{ }^{\circ} \mathrm{C}$ and an effective normal stress of $\sigma_{n}=50 \mathrm{MPa}$. We chose a temperature of $T=92{ }^{\circ} \mathrm{C}$ to place the experiment in the velocity-weakening regime (Verberne et al., 2013), but below the boiling point of $\mathrm{H}_{2} \mathrm{O}$ under standard conditions. For more details about the triaxial direct-shuttle vessel see Verberne et al. (2014). The experimental conditions resulted in a deformation time of $t_{\text {def }}=12.7$ hours and a total contact time, including mounting, heating, cooling, and unmounting, of approximately $t_{\text {tot }}=17$ hours.

All experiments are summarised in Table 1, but in the following we focus on selected experiments where we could ensure a continuous, analytical workflow.

\begin{tabular}{|c|c|c|c|c|c|c|}
\hline Sample name & Material & Pore fluid & $\begin{array}{c}\text { Temperature } T \\
{\left[{ }^{\circ} \mathrm{C}\right]}\end{array}$ & $\begin{array}{c}\text { Normal } \\
\text { stress } \sigma_{n} \\
{[\mathrm{MPa}]}\end{array}$ & $\begin{array}{c}\text { Velocity } \\
v\end{array}$ & Displacement \\
\hline UU_cc_0001 & calcite & $\begin{array}{l}\text { deionised } \\
\text { water }\end{array}$ & 92 & 50 & $0.1 \mu \mathrm{m} / \mathrm{s}$ & $4.6 \mathrm{~mm}$ \\
\hline $\begin{array}{c}\text { UU_cc- } \\
\text { 180_0002 }\end{array}$ & calcite & $\mathrm{H}_{2}{ }^{18} \mathrm{O}$ & RT & 50 & $0.1 \mu \mathrm{m} / \mathrm{s}$ & $4.6 \mathrm{~mm}$ \\
\hline $\begin{array}{c}\text { UU_cc- } \\
\text { 180_0003* }\end{array}$ & calcite & $\mathrm{H}_{2}{ }^{18} \mathrm{O}$ & 92 & 50 & $0.1 \mu \mathrm{m} / \mathrm{s}$ & $4.6 \mathrm{~mm}$ \\
\hline LHV982 & calcite & $\begin{array}{l}\text { deionised } \\
\text { water }\end{array}$ & $R T$ & 2 & $1 \mathrm{~m} / \mathrm{s}$ & $20 \mathrm{~m}$ \\
\hline LHV983* & calcite & $\mathrm{H}_{2}{ }^{18} \mathrm{O}$ & $R T$ & 2 & $1 \mathrm{~m} / \mathrm{s}$ & $20 \mathrm{~m}$ \\
\hline LHV984* & calcite & $\mathrm{H}_{2}{ }^{18} \mathrm{O}$ & RT & 4 & $1 \mathrm{~m} / \mathrm{s}$ & $20 \mathrm{~m}$ \\
\hline LHV985 & calcite & $\mathrm{H}_{2}{ }^{18} \mathrm{O}$ & RT & 2 & $1 \mathrm{~m} / \mathrm{s}$ & $2 m$ \\
\hline LHV986 & $\begin{array}{c}\text { calcite }+5 \% \\
\text { smectite }\end{array}$ & $\mathrm{H}_{2}{ }^{18} \mathrm{O}$ & RT & 2 & $1 \mathrm{~m} / \mathrm{s}$ & $20 \mathrm{~m}$ \\
\hline
\end{tabular}




\subsubsection{Sample preparation}

Low- and high-velocity experiment samples were embedded horizontally in epoxy (Araldite 2020○). After hardening, the embedded samples were vertically embedded again in epoxy. After the second embedding had finished hardening, the samples were cut normal to the sample surface and perpendicular to the slip direction. The samples were mounted on a $2.54 \mathrm{~cm}$ aluminium stub and subsequent polishing of the cross sections was executed with a $1 \mu \mathrm{m}$ and $0.3 \mu \mathrm{m}$ diamond suspension and finalized with $0.025 \mu \mathrm{m}$ colloidal silica polish. In addition, several samples were cut with a razorblade and directly investigated without any epoxy embedding. This procedure allowed us to check for any contribution of epoxy to the measured signal during spectroscopic analyses.

\subsubsection{Crystal orientation measurements}

An electron-backscatter diffraction (EBSD) map of a high-velocity sample enriched in ${ }^{18} \mathrm{O}$ was acquired using a Philips XL30 scanning electron microscope (SEM) equipped with an Oxford Instruments Nordlys 2 CCD camera. The map was acquired with an acceleration voltage of $30 \mathrm{kV}$ and $9.54 \mathrm{nA}$ probe current with a step size of $0.2 \mu \mathrm{m}$. Orientation data were processed using the MTEX 4.5.2 toolbox (Hielscher and Schaeben, 2008; Bachmann et al., 2011). The reference frame was set with the $\mathrm{x}$-axis to the east, $\mathrm{y}$-axis to the south and z-axis out of plane. Grain boundaries were defined as misorientation angles $>10^{\circ}$ and subgrain boundaries were defined as misorientation angles in the range $1-10^{\circ}$. Unindexed pixels or single pixels matched as a different phase were removed from the EBSD dataset and unindexed pixels were filled with the average orientation of their grain neighbours. Grains $<5$ pixels were excluded from the EBSD dataset. The optimum half-width for contoured EBSD pole figures was estimated to $15^{\circ}$ using the De la Vallée-Poussin kernel approach. Misorientation inverse pole Figures (MIPF) were plotted for subgrain-boundary misorientation angles of $1-10^{\circ}$.

\subsubsection{Nanoscale analysis and phase identification}

For reduction of charge accumulation, the cross sections were coated with an 8-nm thick Pt/Pd layer for nanostructural analysis. Electron-transparent foils of the high-velocity sample LHV 983 were fabricated with a FEI Helios Nanolab G3 focused ion beam scanning electron microscope (FIB-SEM). Analysis of the FIB-foils was performed with a FEI Talos F200x (scanning) transmission electron microscope 
((S)TEM) at $200 \mathrm{kV}$ acceleration voltage. Element distribution mapping was performed in STEM mode to capture the characteristic energy dispersive X-rays (EDX).

Electron energy loss spectroscopy (EELS) data were acquired with a ThermoFisher Scientific/FEI Titan Themis G3 60-300 transmission electron microscope (Westfälische Wilhelms-Universität, Münster, Germany). This microscope is equipped with a high-brightness X-FEG (acceleration voltage $300 \mathrm{kV}$ ), a monochromator, an aberration-corrected objective system producing sub-0.1 nm spatial resolution in TEM mode and a high-resolution post-column Gatan Quantum ER EEL spectrometer. All spectra were recorded in STEM mode using a $50 \mu \mathrm{m}$ condenser aperture and beam currents between 100-300 pA. The EEL spectrometer was, therefore, coupled to the TEM in diffraction mode, resulting in a spatial resolution of acquired spectrum images defined by the actual probe size of a few $\mathrm{nm}$. We used a $2.5 \mathrm{~mm}$ entrance aperture to the spectrometer and a dispersion of 0.1 $\mathrm{eV} /$ channel for acquired spectra. All data were acquired in Dual-EELS mode, where the low-loss region from 220 to $420 \mathrm{eV}$ energy loss was centered over the carbon $\mathrm{K}$ edge and the high-loss region from 460 to $660 \mathrm{eV}$ energy loss centered over the oxygen K-edge. Spectra were deconvolved with the zero-loss peak to remove the effect of plural scattering and the background was subtracted assuming a powerlaw function with Gatan's Digital Micrograph software package.

\subsubsection{Raman Spectroscopy}

Raman spectroscopy was carried out using a WiTec Alpha 300R confocal microscope to confirm possible incorporation of ${ }^{18} \mathrm{O}$ into the calcite crystal structure and to identify and characterise other reaction products. The incorporation of ${ }^{18} \mathrm{O}$ into the calcite crystal structure results in an increase in molecular weight of the calcite-carbonate group and shifts the bands that are associated with it to positions at lower wavenumbers (Perdikouri et al., 2011). This is due to the bond vibrations between the oxygen and carbon atoms inside the carbonate group requiring a higher amount of energy to initiate the same bond vibrations upon the formation of increasingly heavier isotopologues. We used a laser with a wavelength of $\lambda=488$ $\mathrm{nm}$ and a spectral grating of 600 grooves/mm in our measurements to facilitate the fast mapping of the samples, limiting exposure to the laser as much as possible. Acquisition and post-processing of the data was executed with WiTec ProjectFour 4.1 and 5.0 as well as Fityk 1.5.3 (Wojdyr, 2010). Additional Raman spectroscopic 
measurements were conducted on high-velocity samples not embedded in Araldite 2020 C. This was done to exclude any contribution of epoxy to the presence of carbonaceous phases within the sample (see Appendix for Raman spectra of experimental materials used).

\subsubsection{Stable isotope analyses}

Nanoscale-resolved secondary ion mass spectroscopy (nanoSIMS) was performed at Utrecht University to quantify the spatial ${ }^{18} \mathrm{O}$ distribution. Isotope maps were acquired with a Cameca 50L at $16 \mathrm{kV}$ primary ion energy and 0.5-2 pA ion-beam current. For reduction of charge accumulation, the cross sections were coated with a 20-nm thick Au layer for secondary ion mass isotope mapping. The selected regions of interest were pre-sputtered with the primary $\mathrm{Cs}^{+}$-ion beam until the secondary-ion yield stabilised. Scanning of the ion beam over an 20x20 $\mu \mathrm{m}$ area with $\sim 1 \mathrm{~ms} /$ pixel dwell time results in a probe diameter and thus $\mathrm{x}-\mathrm{y}$ spatial resolution of $\sim 50 \mathrm{~nm}$. An additional electron-flooding gun at $-8009 \mathrm{~V}$ was used to reduce positive charging at the sample surface. For the presented isotope maps, the same field-of-view was measured 100 times to increase the signal-to-noise ratio and the individual measurements were aligned and accumulated. Because of the multicollection system, ${ }^{16} \mathrm{O}$ - and ${ }^{18} \mathrm{O}$-oxygen isotopes were recorded simultaneously in negative mode. Post-processing of the nano-SIMS data was executed with the LANS MATLAB tool (Polerecky et al., 2012).

To resolve isotope substructures inside the fine-grained matrix, ultra-highresolution secondary ion mass spectroscopy (SIMS) imaging was performed with a Helium Ion Microscope (HIM) coupled with a mass spectrometer (Wirtz et al., 2016) at Luxembourg Institute for Science and Technology (LIST). The regions of interest were defined in secondary-electron mode with a He-beam at $20 \mathrm{keV}$ and $1 \mathrm{pA}$. The SIMS images were acquired using $20 \mathrm{keV} \mathrm{Ne}$ primary ion with a probe current of 3 pA leading to probe diameter of $15-25 \mathrm{~nm}$. The raster size was $5 \times 5 \mu \mathrm{m}$ with a matrix of $512 \times 512$ pixels. As for the nanoSIMS analysis the presence of the multicollection system allowed both ${ }^{16} \mathrm{O}$ and ${ }^{18} \mathrm{O}$ isotopes to be recorded simultaneously.

\subsection{Results of high-velocity experiments}

\subsubsection{Mechanical data}

The evolution of the experimental data for the high-velocity experiments $(v$ $=1 \mathrm{~m} / \mathrm{s}, \sigma_{n}=2$ and $4 \mathrm{MPa}$ ) is shown in Figure 2. We summarise the resulting 
experimental parameters of dry and wet experiments in Table 2. For the samples deformed with pore fluid at seismic conditions we observe a peak-friction coefficient during pre-shear of $\mu_{p}=0.89$ (LHV982, $v=1 \mathrm{~m} / \mathrm{s}, \sigma_{n}=2 \mathrm{MPa}$, deionised water), $\mu_{p}=$ $0.76\left(\mathrm{LHV} 983, v=1 \mathrm{~m} / \mathrm{s}, \sigma_{n}=2 \mathrm{MPa}, \mathrm{H}_{2}{ }^{18 \mathrm{O}}\right)$ and $\mu_{p}=0.8\left(\mathrm{LHV} 984, v=1 \mathrm{~m} / \mathrm{s}, \sigma_{n}=4\right.$ $\mathrm{MPa}, \mathrm{H}_{2}{ }^{18} \mathrm{O}$ ) and a steady-state friction coefficient of $\mu_{s s}=0.17$ (LHV982, $v=1 \mathrm{~m} / \mathrm{s}, \sigma_{n}$ $=2 \mathrm{MPa}$, deionised water), $\mu_{s s}=0.17$ (LHV983, $\left.v=1 \mathrm{~m} / \mathrm{s}, \sigma_{n}=2 \mathrm{MPa}, \mathrm{H}_{2}{ }^{18} \mathrm{O}\right)$ and $\mu_{s s}=$ 0.10 (LHV984, $v=1 \mathrm{~m} / \mathrm{s}, \sigma_{n}=4 \mathrm{MPa}, \mathrm{H}_{2}{ }^{18} \mathrm{O}$ ). The friction coefficient of LHV984 reaches values as low as $\mu=0.07$ towards the end of the experiment. In comparison, the dry experiment reaches a peak friction of $\mu_{p}=0.76$ and a steady-state friction coefficient of $\mu_{s s}=0.23-0.25$ resulting in $\Delta \mu=0.53$ (Fig. 2a, dry). The slip-weakening distances $D_{w}$ determined for the wet experiments are: $D_{w}=2.47 \mathrm{~m}$ (LHV982, $v=1$ $\mathrm{m} / \mathrm{s}, \sigma_{n}=2 \mathrm{MPa}$, deionised water), $D_{w}=2.25 \mathrm{~m}\left(\mathrm{LHV} 983, v=1 \mathrm{~m} / \mathrm{s}, \sigma_{n}=2 \mathrm{MPa}, \mathrm{H}_{2}{ }^{18} \mathrm{O}\right)$ and $D_{w}=1.52 \mathrm{~m}\left(\mathrm{LHV} 984, v=1 \mathrm{~m} / \mathrm{s}, \sigma_{n}=4 \mathrm{MPa}, \mathrm{H}_{2}{ }^{18} \mathrm{O}\right)$.

\begin{tabular}{|c|c|c|c|c|c|c|}
\hline $\begin{array}{l}\text { Sample } \\
\text { name }\end{array}$ & $\begin{array}{c}\text { Velocity v } \\
{[\mathrm{m} / \mathrm{s}]}\end{array}$ & $\begin{array}{c}\text { Normal } \\
\text { stress } \sigma_{n} \\
{[\mathrm{MPa}]}\end{array}$ & $\begin{array}{l}\text { Peak friction } \\
\text { coefficient } \mu_{p}\end{array}$ & $\begin{array}{l}\text { Steady-state } \\
\text { friction } \\
\text { coefficient } \mu_{\text {ss }}\end{array}$ & $\begin{array}{c}\text { Slip weakening } \\
\text { distance }[\mathrm{m}]\end{array}$ & Pore fluid \\
\hline LHV982 & 1 & 2 & 0.89 & 0.17 & 2.47 & $\begin{array}{c}\text { deionised } \\
\text { water }\end{array}$ \\
\hline LHV983 & 1 & 2 & 0.76 & 0.17 & 2.25 & $\mathrm{H}_{2}{ }^{18} \mathrm{O}$ \\
\hline LHV984 & 1 & 4 & 0.8 & 0.1 & 1.52 & $\mathrm{H}_{2}{ }^{18} \mathrm{O}$ \\
\hline $\begin{array}{c}\text { Dry } \\
\text { sample }\end{array}$ & 1 & 2 & 0.76 & $0.23-0.25$ & 5.4 & no \\
\hline
\end{tabular}

While the wet experiments show a sharp drop in friction coefficient within the first meter of displacement, the dry experiment has a $D_{w}=5.4 \mathrm{~m}$ and reaches a first plateau at $\mu=0.39$ after three meters of displacement and attains the lowest steady-state friction coefficient value of $\mu_{s s}=0.23$ after about $12 \mathrm{~m}$ displacement. The measured change in thickness during the wet experiments with $\sigma_{n}=2 \mathrm{MPa}$ show no dilatation during the initial drop in friction coefficient and stay constant during the first $6 \mathrm{~m}$ of displacement. In contrast, the wet experiment with $\sigma_{n}=4 \mathrm{MPa}$ starts to dilate shortly after the friction coefficient drops (Fig. 2b). The maximum total change in thickness is about $0.1 \mathrm{~mm}$ after $20 \mathrm{~m}$ of displacement. Temperatures monitored during the wet experiments show a dependence on the normal stress. While experiments with a normal load of $2 \mathrm{MPa}$ show a peak measured temperature of 
136-154 ${ }^{\circ} \mathrm{C}$, the experiment run with a normal load of $4 \mathrm{MPa}$ reaches a peak measured temperature of $207^{\circ} \mathrm{C}$ (Fig. 2c).

a

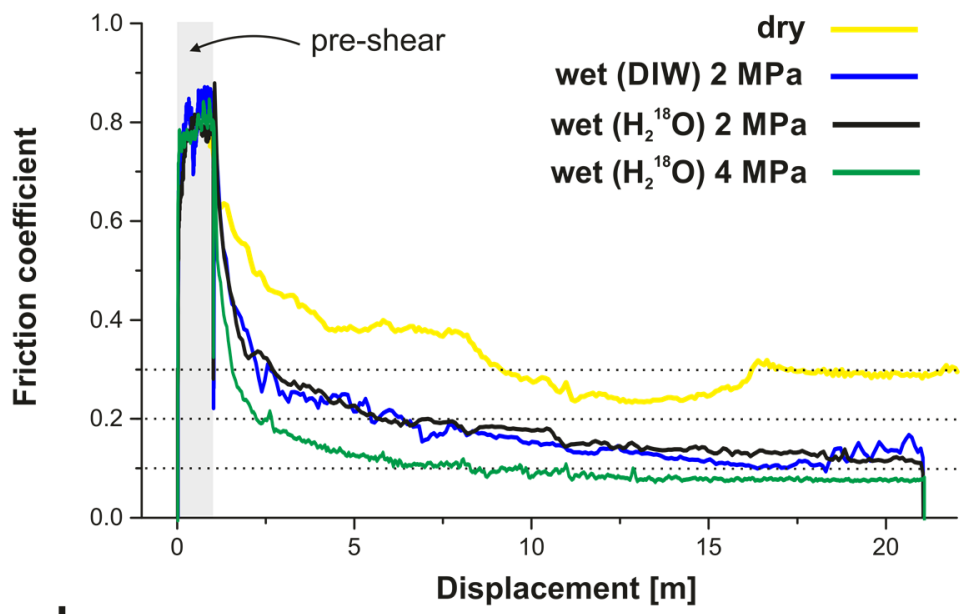

b

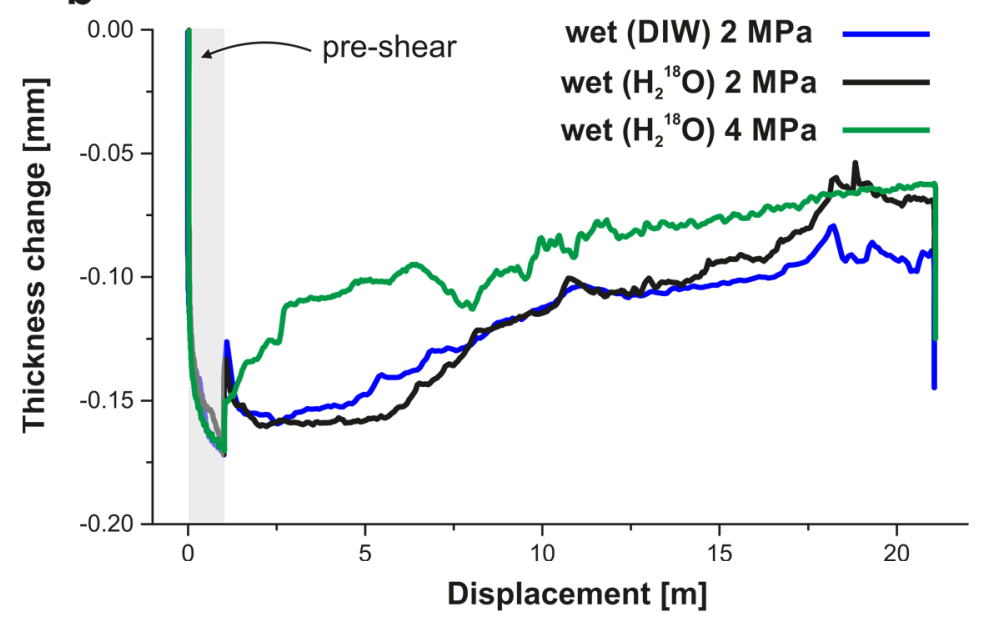

C

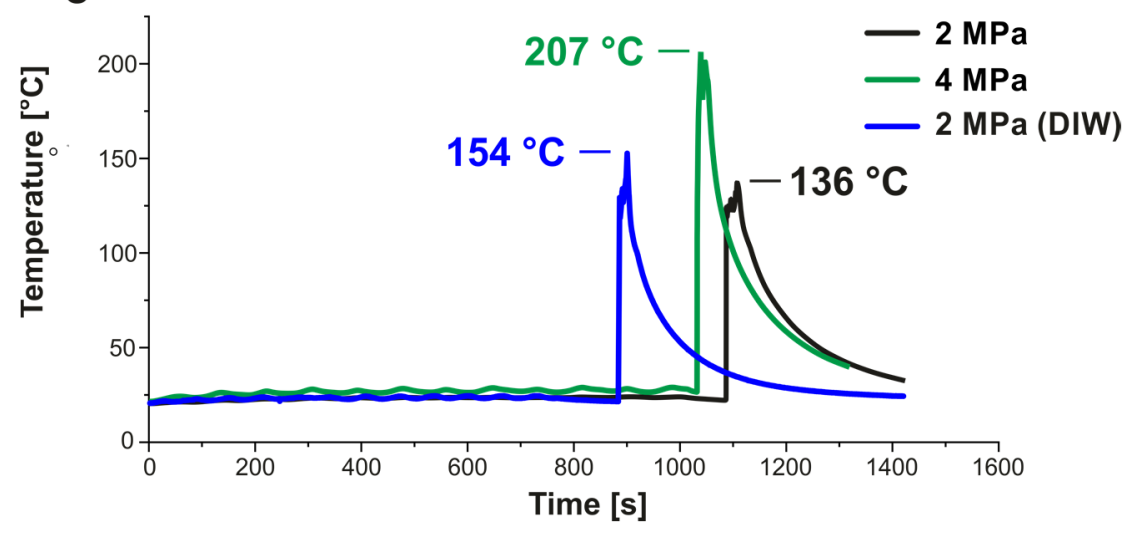


Figure 2: (previous page) Overview of high-velocity experimental data. $\underline{\text { a: }}$ Evolution of friction coefficient for wet deformation with pore fluid and dry experiment. $\underline{b}$ : Dilatation data of wet samples from $\boldsymbol{a}$ : The samples run at 2

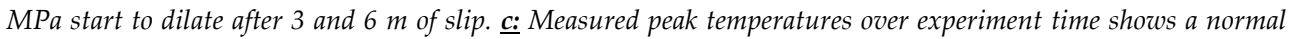
stress dependence with higher temperatures at $4 \mathrm{MPa}$ compared to $2 \mathrm{MPa}$. DIW = deionised water.

\subsubsection{Microstructures}

The high-velocity sample LHV983 $\left(v=1 \mathrm{~m} / \mathrm{s}, \sigma_{n}=2 \mathrm{MPa}\right)$ exhibits three micro-structural domains with large grains within a fine-grained matrix (Fig. 3a, 1, 2 and 3, Fig. 3b), forming a hanging-wall and footwall structure. Other high-velocity experiments show a similar structure but the sample LHV983 exhibits the bestpreserved example and is therefore used for further investigation. A lower backscatter contrast in the top domain (Fig. 3a, 1) indicates a less cohesive microstructure with porosity and large grains. The grain size decreases abruptly to a dense and cohesive region in the middle domain (Fig. 3a, 2). The bottom domain of the sample contains a higher number of large grains but shows overall more cohesion and lower porosity (Fig. 3a, 3) compared to domain 1 . Small grains form localised, horizontal bands in the middle section of the sample (Fig. 3b, black arrows).

\subsubsection{Nanostructures}

Figures $3 \mathrm{c}$ and $3 \mathrm{~d}$ show the nanostructure of the high-velocity experiment LHV983 $\left(v=1 \mathrm{~m} / \mathrm{s}, \sigma_{n}=2 \mathrm{MPa}\right)$, exhibiting large grains intermingled with a lowdiffracting phase filling the interstitial regions. Large grains display a high diffraction contrast relating to a high defect content (Fig. 3c and 3d); the lowdiffracting phase does not show a crystal structure (Fig. 3d). EDX mapping reveals the element composition of the low-diffracting phase to be carbon (Fig. 3f). Grains of $<50 \mathrm{~nm}$ diameter show an idiomorphic crystal shape and are situated inside the carbon phase (Fig. 3d and e). EELS measurements of the low-diffracting carbon phase identify the material to be amorphous carbon with the onset of the carbon Kedge at $284 \mathrm{eV}$ energy loss and exhibit a characteristic, featureless $\sigma^{*}$ region (Fig. $3 g$ ). 

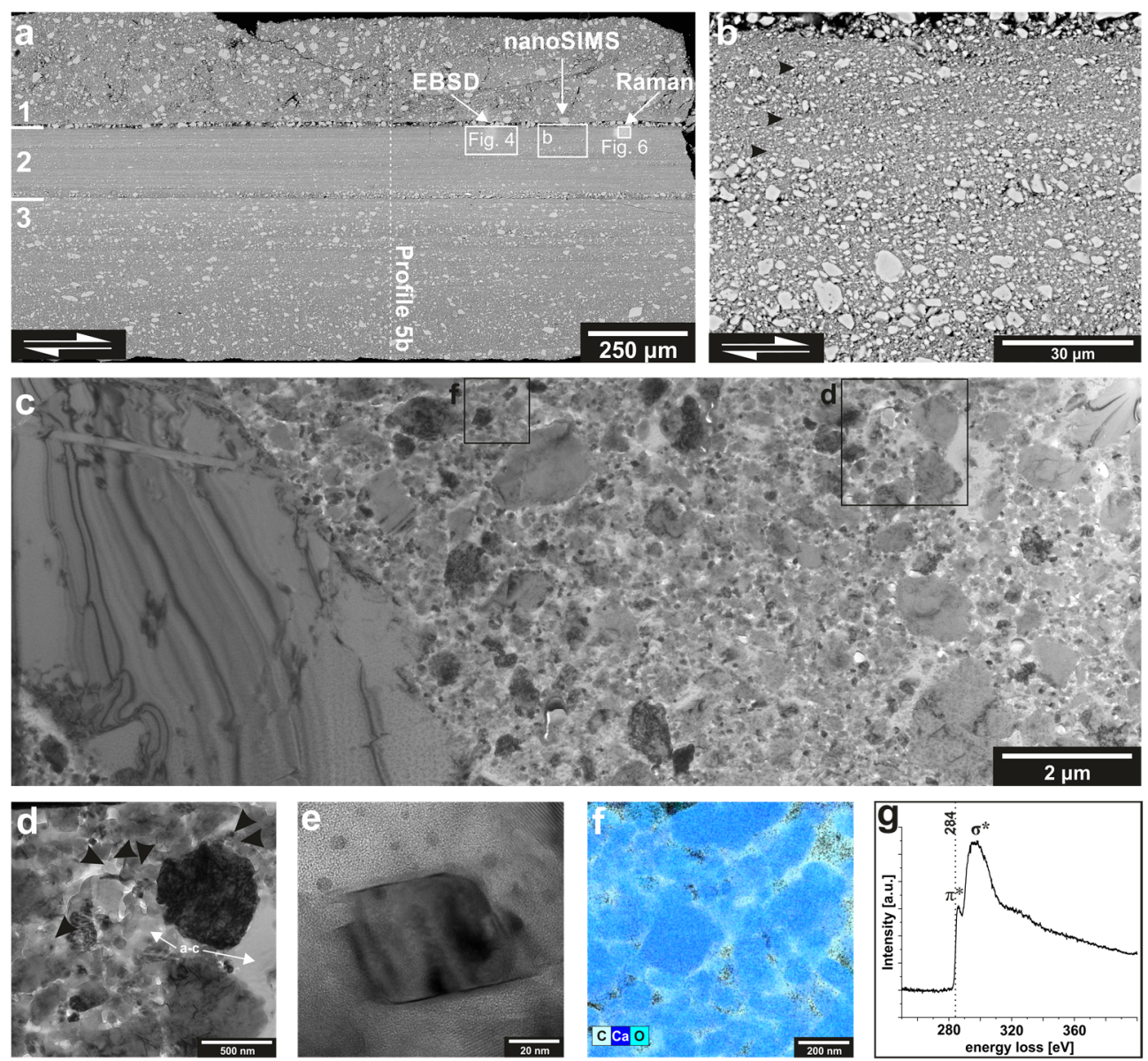

Figure 3: Overview of deformation structures on the micro-, $(\boldsymbol{a} \mathcal{E} \boldsymbol{b})$ and nanoscale $(\boldsymbol{c}-\boldsymbol{f})$. $\mathrm{a}$ : Backscattered-electron image of sample cross section ( $L H V$ 983, $\sigma_{n}=2 \mathrm{MPa}$ ). Cross section shows distinct domains of varying grain size and compaction (1, 2 and 3). Dashed line indicates normalised isotope profile from Figure 5b. b: Backscatteredelectron image of nano-SIMS measuring area in Fig. $6 b$. Black arrows indicate bands of reduced grain size. c: Brightfield TEM image showing high-diffracting, large grains, and a fine-grained matrix with a low-diffracting phase in the interstitial region. $\underline{d}$ : Bright-field TEM close-up from b: showing a mixture of amorphous carbon (a-c) and small crystals (black arrows). Large grains exhibit a high diffraction contrast indicating a high defect content. $\underline{\boldsymbol{e}}$ : Highresolution TEM image showing an idiomorphic calcite crystal situated inside amorphous carbon. $\ldots$ STEM-EDX map from region in $c$, showing a carbon phase in between grains. g: STEM-EELS spectrum of carbon phase presented in c: to $f$ : indicating that the carbon phase is amorphous.

\subsubsection{Crystal orientation}

Figure 4 summarises the crystal-orientation measurements for calcite of the high-velocity experiment LHV983 $\left(v=1 \mathrm{~m} / \mathrm{s}, \sigma_{n}=2 \mathrm{MPa}\right.$ ) acquired in domain 2 (see Fig. 3a). Figure 4 a displays the backscattered-electron image of the measuring area and Figure $4 \mathrm{~b}$ shows the resulting crystal orientation map colour-coded according to the scheme shown as inset in Figure $4 \mathrm{~d}$. Contoured pole figures in Figure 4c 
exhibit a crystallographic preferred orientation (CPO) of the (0001) and $\{\overline{1} 018\}$ planes, $<\overline{1} 2 \overline{1} 0>$ axes and the $<40 \overline{4} 1>$ direction subparallel to the slip direction with an antithetic inclination of the crystal axes against the slip direction. The (0001) planes show a weak CPO with multiples of uniform distribution (MUD) of 0.47-2.3 and the $<\overline{1} 2 \overline{1} 0>$ axes exhibit MUD of 0.58-1.4. The $\{\overline{1} 018\}$ planes show MUD of 0.59-1.7 and the $<40 \overline{4} 1>$ direction have MUD of $0.71-1.1$. The MIPF in Figure $4 \mathrm{~d}$ displays a subgrain misorientation rotation around the $<\overline{1} 100>$ axes.
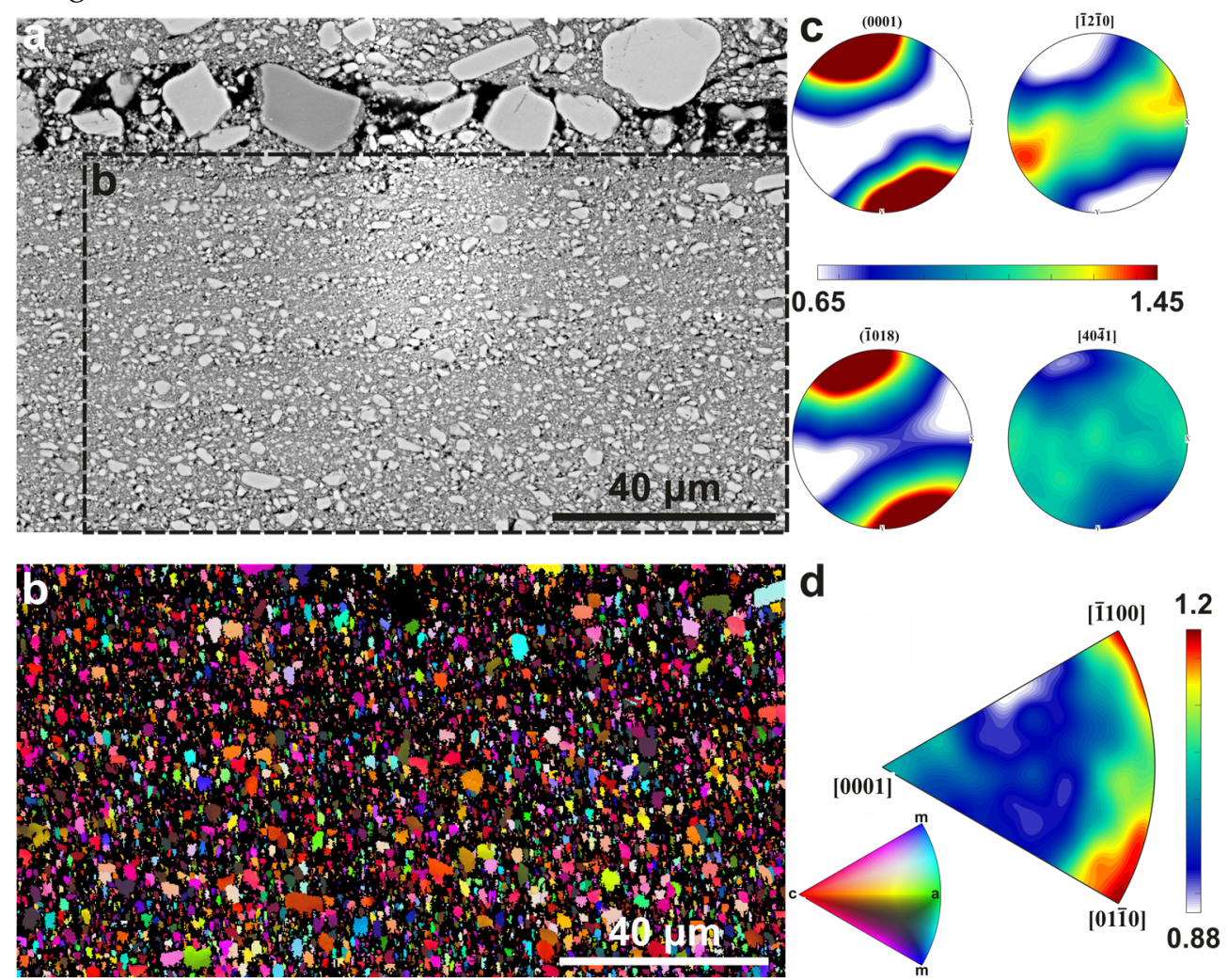

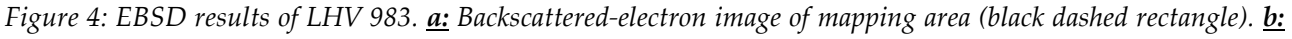
Crystal orientation map with Inverse pole figure parallel y (IPF-Y) colour key form inset in $\boldsymbol{d}$. c: Contoured pole Figures of $(0001),\{\overline{1} 018\},<\overline{1} 2 \overline{1} 0>$ and $<40 \overline{4} 1>$. d: MIPF of misorientation axes associated with misorientation angles of $1-10^{\circ}$.

\subsubsection{Phase identification}

Figure 5a shows a representative Raman spectrum of the high-velocity sample LHV983 deformed at seismic conditions $\left(v=1 \mathrm{~m} / \mathrm{s}, \sigma_{n}=2 \mathrm{MPa}\right)$. Although the experimental system is set up as monomineralic, the Raman spectra in Figure 5a and $5 c$ indicate the presence of three crystalline phases and one amorphous phase. The band position at $1086 \mathrm{~cm}^{-1}$, correspond to the v1-vibrational mode of the 
carbonate group $\mathrm{C}^{16} \mathrm{O}_{3^{2}}$, identifies the calcite starting material. Formation of a broad, overlapping $\mathrm{D},\left(1342 \mathrm{~cm}^{-1}\right)$ and $\mathrm{G}\left(1600 \mathrm{~cm}^{-1}\right)$ band identifies a disordered carbon phase, which is likely the same material identified at higher spatial resolution as amorphous carbon via EELS in Figure 3g. We observe three new band positions associated with the fine-grained matrix at $1065 \mathrm{~cm}^{-1}, 1046 \mathrm{~cm}^{-1}$ and $1024 \mathrm{~cm}^{-1}$, corresponding to the formation of ${ }^{18} \mathrm{O}$-bearing calcite. These band positions can be directly related to the v1-vibrational mode of the Ca-carbonate isotopologues $\mathrm{C}^{16} \mathrm{O}_{2}{ }^{18} \mathrm{O}^{2-}, \mathrm{C}^{16} \mathrm{O}^{18} \mathrm{O}_{2}{ }^{2-}$ and $\mathrm{C}^{18} \mathrm{O}_{3^{2}}$, respectively, within the calcite crystal structure (Perdikouri et al., 2011). Figure $5 \mathrm{~b}$ shows the normalised ${ }^{18} \mathrm{O} /\left({ }^{16} \mathrm{O}+{ }^{18} \mathrm{O}\right)$ ratio for the profile line indicated in Figure 3a calculated using the combined and summarised intensity of the different isotopologue bands. The profile indicates a continuous signal of ${ }^{18} \mathrm{O}$ within calcite throughout the whole sample cross section. Figure $5 \mathrm{c}$ shows the sharp band of the $v 1(\mathrm{OH})$-stretching mode of crystalline portlandite $\left(\mathrm{Ca}(\mathrm{OH})_{2}\right)$ at $3612 \mathrm{~cm}^{-1}$ consistent with what has been reported in the literature (3620 $\left.\mathrm{cm}^{-1}\right)$ for $\mathrm{Ca}\left({ }^{16} \mathrm{OH}\right)_{2}$ measured with a $633 \mathrm{~nm}$ laser (Black et al., 2006). No residual $\mathrm{H}_{2}{ }^{18} \mathrm{O}$ in pores was detected as this would produce a broad band centred around $3250 \mathrm{~cm}^{-1}$ (Brooker et al., 1989). The spatial distribution of portlandite and amorphous carbon is summarised as hyperspectral maps in Figures $5 \mathrm{~d}$ and $5 \mathrm{e}$.

\subsubsection{Stable isotope analyses}

Figure 6 summarises the stable-isotope distribution of the selected high-velocity experiments LHV983 $\left(v=1 \mathrm{~m} / \mathrm{s}, \sigma_{n}=2 \mathrm{MPa}\right)$ and LHV984 $\left(v=1 \mathrm{~m} / \mathrm{s}, \sigma_{n}=4 \mathrm{MPa}\right)$. The spatial distribution of the ${ }^{18} \mathrm{O}$-bearing calcite isotopologues is summarised in Figure $6 \mathrm{a}$ and shows a heterogeneous distribution with the highest relative intensity of $\mathrm{C}^{16} \mathrm{O}_{2}{ }^{18} \mathrm{O}^{2-}$ correlating with the spatial distribution of portlandite (Fig. $5 \mathrm{~d}$ ). The isotopologues $\mathrm{C}^{16} \mathrm{O}^{18} \mathrm{O}_{2} 2-$ and $\mathrm{C}^{18} \mathrm{O}_{3^{2-}}$ show a lower intensity and are spatially less heterogeneous. The fine-grained matrix shows an ${ }^{18} \mathrm{O}$-content of $6.3-31.6 \%$ whilst large grains exhibit no ${ }^{18} \mathrm{O}$-enrichment (Fig. 6b). The absence of ${ }^{18} \mathrm{O}$-enrichment in large grains suggests that they are survivor grains of the starting material, consistent with a high defect content related to mechanical action as observed in the TEM diffraction contrast. Additional ultra-high resolution HIM-SIMS analyses reveals a heterogeneous distribution of ${ }^{18} \mathrm{O}$ inside the fine-grained matrix with spots of localised ${ }^{18} \mathrm{O}$-intensity as well as zones of high ${ }^{18} \mathrm{O}$-intensity along grain boundaries (Fig. 6c). 

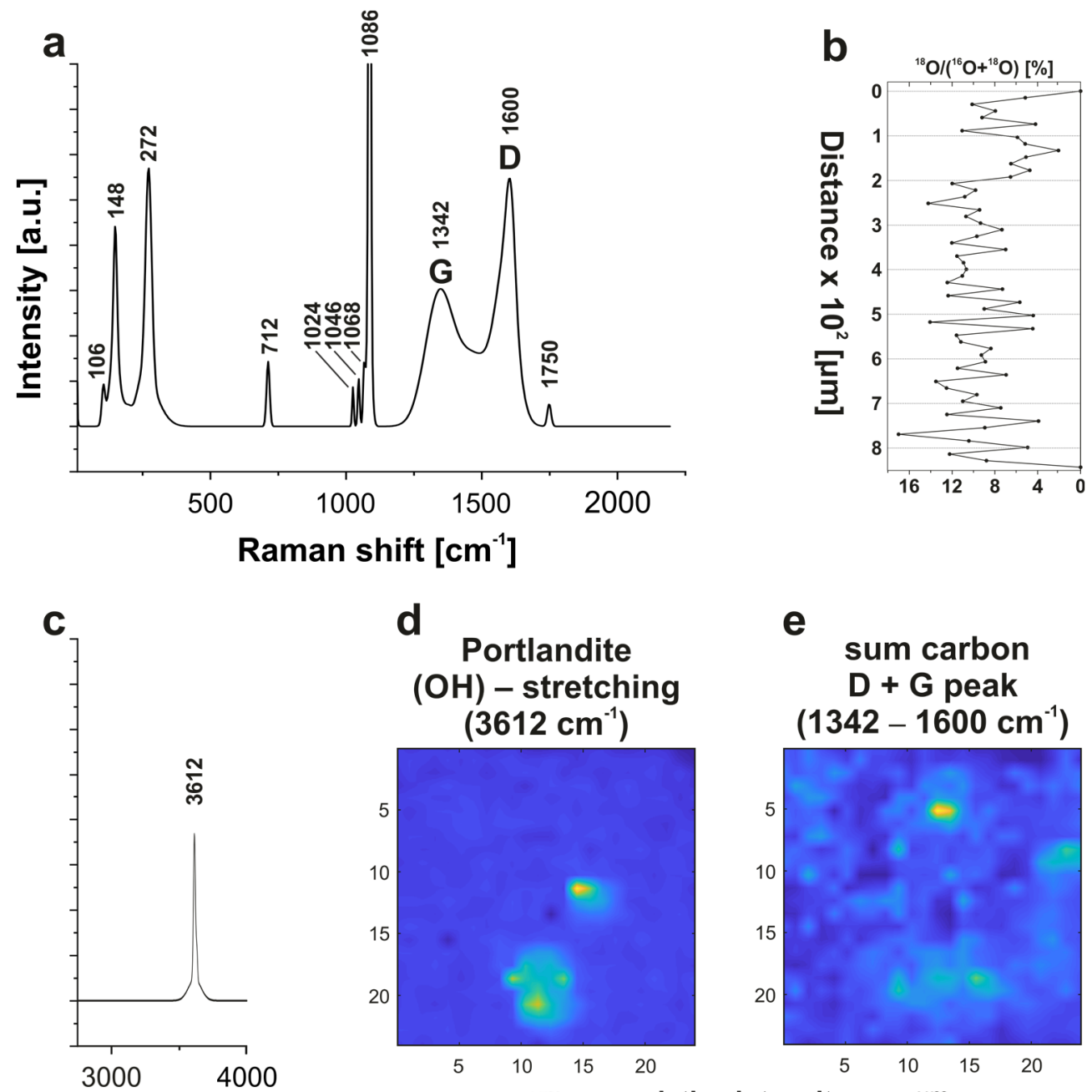

e

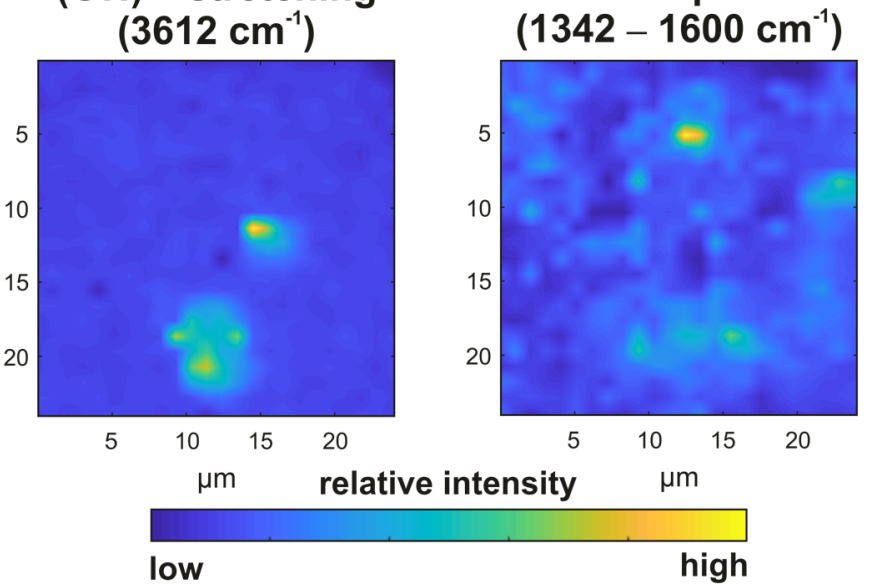

\section{Raman shift $\left[\mathrm{cm}^{-1}\right]$}

low

high

Figure 5: Raman spectroscopy results for phase identification. a: Representative Raman spectrum showing the new bands of the starting calcite, carbonate-group isotopologues and disordered carbon. $\underline{\boldsymbol{b}}$ : Raman spectroscopy profile from Figure $3 a$ which exhibited a continuous signal of ${ }^{18} \mathrm{O}$-calcite throughout the whole fault gouge. $\underline{\text { : }}$ Raman spectrum of crystalline portlandite. $\underline{d}$ : Hyperspectral map showing the spatial distribution of portlandite. $\underline{e}$ : Hyperspectral map of disordered carbon distribution. 
a

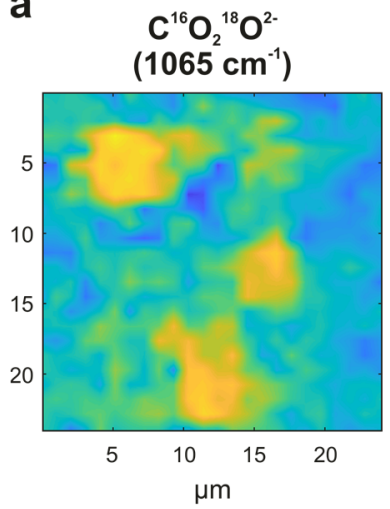

$\mathrm{C}^{16} \mathrm{O}^{18} \mathrm{O}_{2}^{2-}$

$\left(1046 \mathrm{~cm}^{-1}\right)$

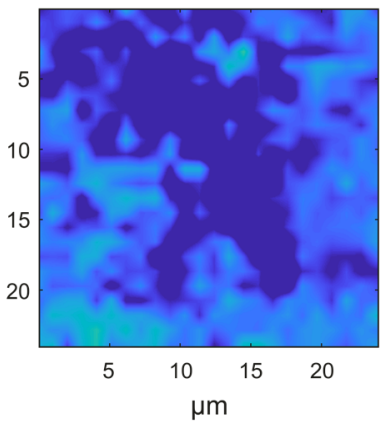

$\mathrm{C}^{18} \mathrm{O}_{3}^{2-}$

$\left(1025 \mathrm{~cm}^{-1}\right)$

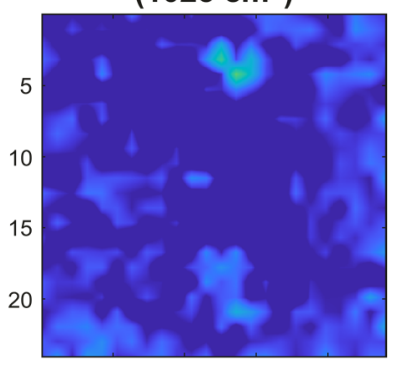

$5 \quad 10 \quad 15 \quad 20$

$\mu \mathrm{m}$ low

b

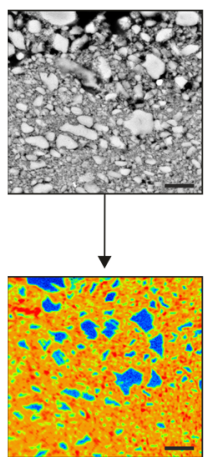

$\log { }^{18} \mathrm{O} /\left({ }^{16} \mathrm{O}+{ }^{18} \mathrm{O}\right)$

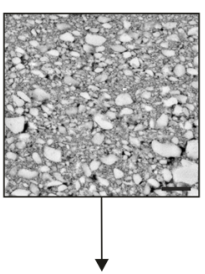

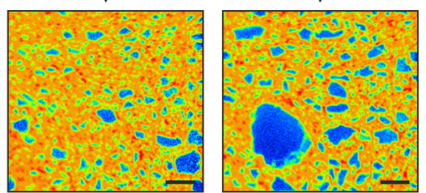

$\begin{array}{lllll}-3 & -2.5 & -2 & -1.5 & -1\end{array}$

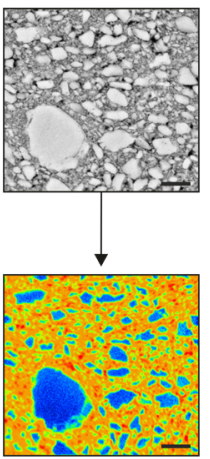

relative intensity

C

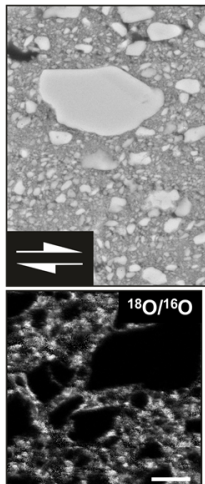

${ }^{18} \mathrm{O} /{ }^{16} \mathrm{O}$
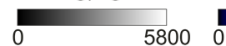

high

Figure 6: High-velocity experiment isotope results a: Hyperspectral maps of a $30 x 30 \mu \mathrm{m}$ area showing the heterogeneous distribution of the isotopologues. $\underline{\boldsymbol{b}}$ : Backscatter electron image showing the locations of the three nano-SIMS maps. The maps exhibit ${ }^{18} \mathrm{O}$-enrichment in the matrix and no ${ }^{18} \mathrm{O}$-enrichment in the large grains. Black scale bar $=3 \mu \mathrm{m}$. $\underline{\text { : }}$ Backscattered-electron image of LHV984, $\sigma_{n}=4 \mathrm{MPa}$. Black rectangle indicates location of HIM-SIMS map. The map shows a localised ${ }^{18} \mathrm{O}$-distribution in the matrix and along grain boundaries. White scale bar $=1 \mu m$.

\subsection{Results of low-velocity experiments}

\subsubsection{Mechanical data}

The low-velocity experiment UU_cc-18O_0003 $\left(v=0.1 \mu \mathrm{m} / \mathrm{s}, \sigma_{n}=50 \mathrm{MPa}, \mathrm{T}\right.$ $=92{ }^{\circ} \mathrm{C}$ ) shows a continuous increase in friction coefficient until a peak-friction coefficient of $\mu_{p}=0.78$ after about $1 \mathrm{~mm}$ of displacement. Friction then decreases to a steady-state value of about $\mu_{s s}=0.6$ until the end of the deformation experiment (Fig. 7). 


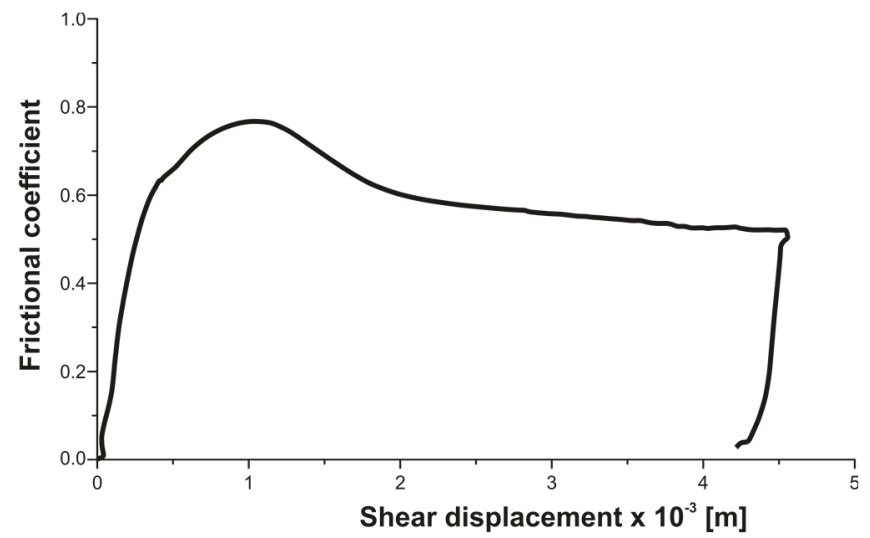

Figure 7: Evolution of friction coefficient with displacement for low-velocity experiment

\subsubsection{Microstructures}

The low-velocity sample UU_cc-18O_0003 $\left(v=0.1 \mu \mathrm{m} / \mathrm{s}, \sigma_{n}=50 \mathrm{MPa}, T=92\right.$ ${ }^{\circ} \mathrm{C}$ ) exhibits a narrow, highly localised zone of reduced grain size at the outer edge of the sample, forming a boundary shear (Fig. 8a and 8b). Planar discontinuities develop at an angle of $\sim 30^{\circ}$ to the boundary shear (Fig. 8a), where the sample shows preferential splitting during sample recovery. An anastomosing network of shear bands develops inside the boundary shear and along these bands, grains tend to have a truncated shape (Fig. $8 \mathrm{~b}$, inset).

\subsubsection{Phase identification}

Figures $8 \mathrm{c}$ to $8 \mathrm{f}$ show the Raman hyperspectral-mapping results of the lowvelocity experiment UU_cc-18O_0003 $\left(v=0.1 \mu \mathrm{m} / \mathrm{s}, \sigma_{n}=50 \mathrm{MPa}, T=92^{\circ} \mathrm{C}\right)$. The lowvelocity experiments were also performed using monomineralic calcite as the starting material, but the Raman spectra indicate again the presence of ${ }^{18} \mathrm{O}$-enriched calcite, the original calcite material as well as amorphous carbon. However, no portlandite is observed in the low-velocity experiments. The isotopologue and amorphous-carbon phase distribution over the boundary-shear area is shown in Figures $8 \mathrm{c}-8 \mathrm{f}$ and exhibit a non-stochastic distribution of the $\mathrm{C}^{16} \mathrm{O}_{2}{ }^{18} \mathrm{O}^{2}$ isotopologue at $1065 \mathrm{~cm}^{-1}$. The $\mathrm{C}^{16} \mathrm{O}_{2}{ }^{18} \mathrm{O}^{2-}$ isotopologue shows also highest intensity in the low-velocity experiment, as observed in the high-velocity experiments. The $\mathrm{C}^{18} \mathrm{O}_{3^{2-}}$ isotopologue exhibits an overall lower signal compared to the $\mathrm{C}^{16} \mathrm{O}_{2}{ }^{18} \mathrm{O}^{2-}$ isotopologue but is homogeneously distributed over the measured area. The disordered carbon phase shows a slightly higher intensity inside the boundary shear, but the intensity otherwise shows no spatial variation. 

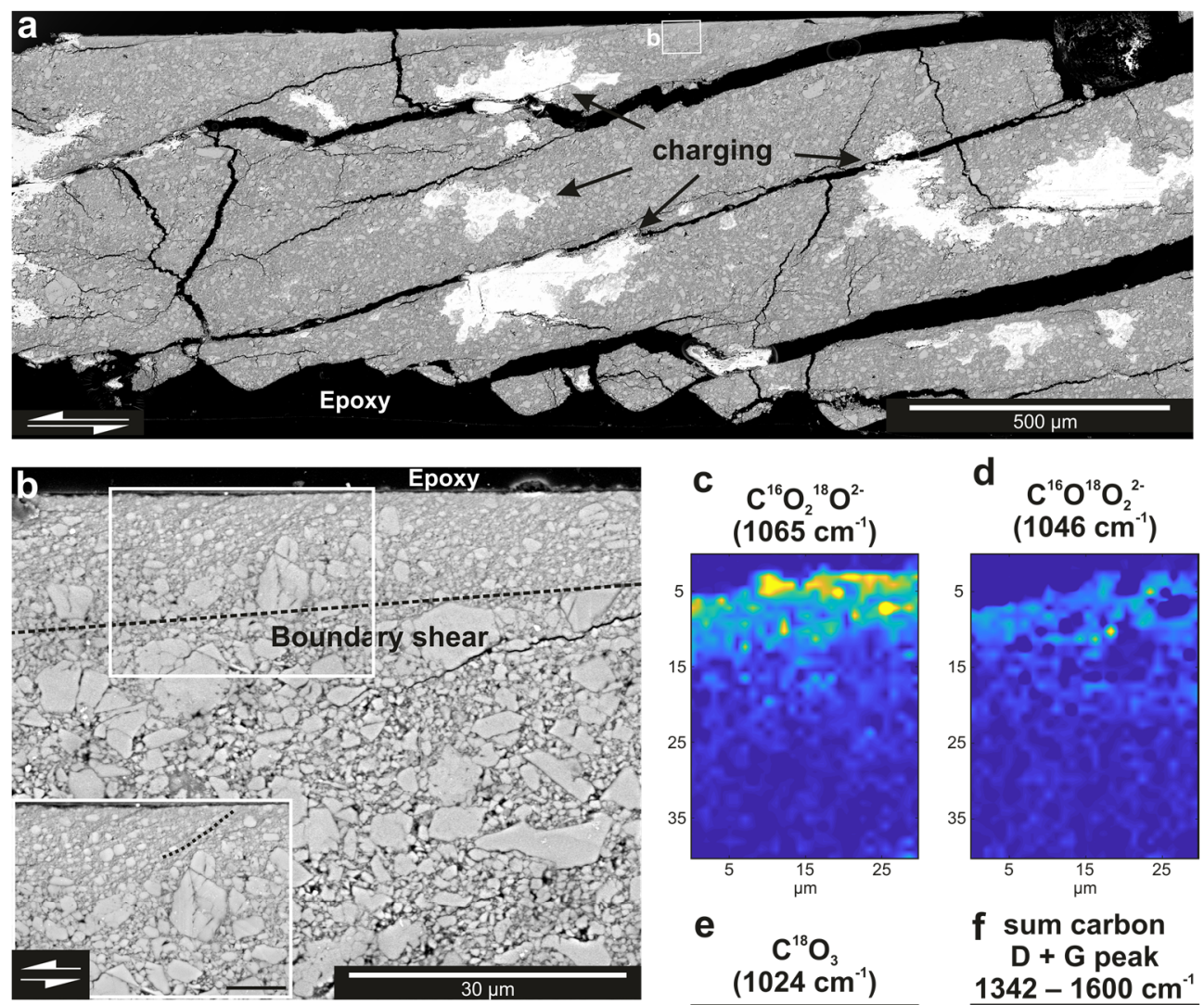

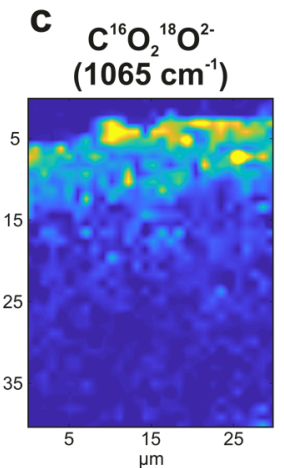

e

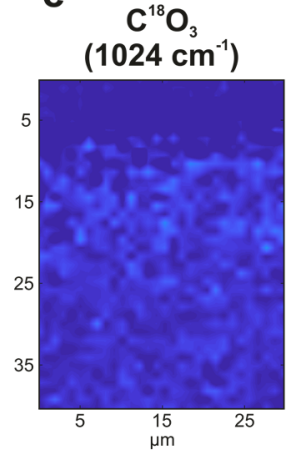

d $\mathrm{C}^{16} \mathrm{O}^{18} \mathrm{O}_{2}^{2-}$ $\left(1046 \mathrm{~cm}^{-1}\right)$

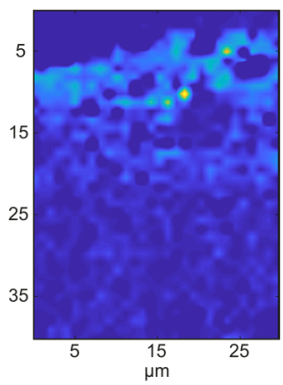

f sum carbon $\mathrm{D}+\mathrm{G}$ peak $1342-1600 \mathrm{~cm}^{-1}$

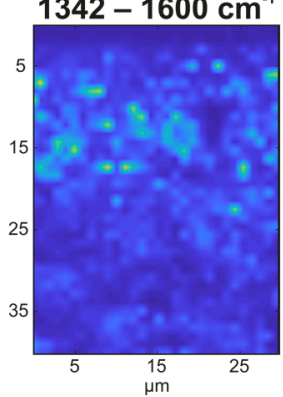

Figure 8: Raman spectroscopy results of low-velocity experiment UU_cc-180_0003. a: Representative backscattered-electron image of microstructure. $\underline{b}$ : Detailed view from $\boldsymbol{a}$ : showing the boundary shear with reduced grain size (above dashed line). Inset: Anastomosing network of shear bands truncates grains (black line) Scale bar

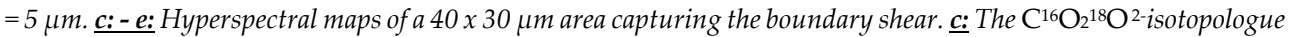
shows a preferred distribution with a higher signal intensity inside the boundary shear. Distribution of the other isotopologues in d: and e: show no preferred enrichment. f: Amorphous carbon exhibits a slightly higher signal within the boundary shear but shows an otherwise homogeneous distribution. 


\subsection{Discussion}

\subsubsection{Solid-state isotope exchange reactions}

It is clear from the analyses that a significant amount of material in both sets of experiments shows isotopic enrichment. Additional mapping via mass spectrometry indicates that the spatial distribution of ${ }^{18} \mathrm{O}$ is concentrated only in the sample matrix and not in the survivor grains. This distribution leads to the interpretation that the ${ }^{18} \mathrm{O}$ incorporation into the carbonate group is restricted to the fine-grained matrix, which for the low-velocity experiment is restricted to the $\sim 50$ $\mathrm{mm}$ thick boundary shear band. To assess how fluids can influence the physical properties of the gouge and whether this is due to fluid-mediated or solid-state reactions, we need to evaluate the potential mechanisms for isotope incorporation into the calcite structure. One mechanism that could explain ${ }^{18} \mathrm{O}$ incorporation into calcite is solid-state diffusion of oxygen. If this mechanism is dominant, isotope enrichment should be equally present in both, the large and the small grains, observed after the experiments. We can approximate the solid-state self-diffusion of oxygen in calcite using an Arrhenius relation:

$$
D=D_{0} \exp (-Q / R T)
$$

where $D$ is the oxygen diffusivity, $D_{0}$ is a pre-exponential factor, $Q$ is the activation energy, $R$ is the gas constant and $T$ is the temperature. Activation energy can decrease with decreasing grain size, but this effect starts to become significant only at grain sizes $<20 \mathrm{~nm}$ (Jiang et al., 2004). To assess the oxygen self-diffusion, we use $D_{0}=7 \times 10^{-9} \mathrm{~m}^{2} / \mathrm{s}, Q=173 \mathrm{~kJ} / \mathrm{mol}$ (Farver, 1994) and obtain a $D=5.5 \times 10^{-31} \mathrm{~m}^{2} / \mathrm{s}$ at $T=$ $136^{\circ} \mathrm{C}$. We approximate the diffusion time $t$ with:

$$
t \approx \frac{x^{2}}{2 D}
$$

where $x$ is the diffusion distance $[\mathrm{m}]$. At a temperature of $136^{\circ} \mathrm{C}$, corresponding to the peak temperature measured in the deformation experiment with $2 \mathrm{MPa}$ normal stress (Fig. 7b), we obtain for a diffusion distance of $x=1 \mathrm{~nm}$ a time of $t \approx 2.85 \times 10^{3}$ years. For a diffusion distance of $x=10 \mathrm{~nm}$, we obtain a time of $t \approx 2.85 \times 10^{6}$ years and for a diffusion distance of $x=100 \mathrm{~nm}$, we obtain $t \approx 2.85 \times 10^{8}$ years. For a temperature of $T=207^{\circ} \mathrm{C}$ (Fig. $7 \mathrm{~b}$ ), the diffusivity changes to $D=1.02 \times 10^{-27} \mathrm{~m}^{2} / \mathrm{s}$ and for the same distances at higher temperature we obtain $t \approx 15.5$ years $(1 \mathrm{~nm}), t \approx$ $1.55 \times 10^{3}$ years $(10 \mathrm{~nm})$ and $t \approx 1.55 \times 10^{5}$ years $(100 \mathrm{~nm})$. We assume now, as an upper limit, that the measured temperatures in Figure $2 \mathrm{c}$ do not reflect the actual temperatures and calculate the diffusion during $t_{\text {def }}=20 \mathrm{~s}$ at $600{ }^{\circ} \mathrm{C}$ related to 
possible, localised heating. The diffusivity at $600{ }^{\circ} \mathrm{C}$ is $D=3.08 \times 10^{-19} \mathrm{~m}^{2} / \mathrm{s}$ and for the distances we obtain $t \approx 1.6$ seconds $(1 \mathrm{~nm}), t \approx 162$ seconds $(10 \mathrm{~nm})$ and $t \approx 4.5$ hours $(100 \mathrm{~nm})$. Thus, solving Eq. (3) for $x$, we estimate that in 20 seconds experiment duration the maximum solid-state diffusion distance of oxygen in calcite would be $x_{600}{ }^{\circ} \mathrm{C} \approx 3 \mathrm{~nm}$, which is not reflected in our results. As water is present in our wet experiments, we expect the temperature increase to be buffered by the transition from liquid water to water vapour, resulting in a temperature evolution along the saturated water-vapour transition curve (Chen et al., 2017). Buffering of the temperature by water-vapour transition would result in maximum temperatures of $T_{\max } \approx 215{ }^{\circ} \mathrm{C}\left(\sigma_{n}=2 \mathrm{MPa}\right)$ and $T_{\max } \approx 250{ }^{\circ} \mathrm{C}\left(\sigma_{n}=4 \mathrm{MPa}\right)$. Accordingly, the resulting diffusion distances are $x_{215}{ }^{\circ} \mathrm{C} \approx 0.0003 \mathrm{~nm}$ and $x_{250}{ }^{\circ} \mathrm{C} \approx 0.0012 \mathrm{~nm}$. Thus, the diffusion lengths estimated are within the edge effect observed in the nanoSIMS data, where changing sputtering rates can generate anomalous, apparent enrichments at the edges of structures (e.g., Fig. 6b). The diffusion distances calculated cannot explain the larger areas of ${ }^{18} \mathrm{O}$ enrichment observable in the highest resolution data observed in the HIM-SIMS for the small grain matrix (Fig. 6b and 6c). In addition, if solid-state diffusion was a dominant mechanism for enrichment, we would expect some enrichment within the survivor grains. This argument is supported by the presence of high diffusion pathways, such as dislocations (Plümper et al., 2012), that are expected in these grains based on the high diffraction contrast in the TEM analysis. Despite the presence of these high diffusion pathways in the survivor grains, solidstate diffusion does not fit with the isotope analyses as the internal sections of the survivor grains retain the natural ${ }^{18} \mathrm{O} / 16 \mathrm{O}$ level expected from the initial materials. These pieces of evidence demonstrate that solid-state diffusion cannot explain the level of enrichment observed in the matrix material. Besides, grains with minimal defect structures observable in the TEM analysis with low diffraction contrast represent new calcite grains that are formed during the experiments. These grains have significant ${ }^{18} \mathrm{O}$ enrichment and are directly responsible for the generation of the carbonate-isotopologue bands of the Raman spectra (Fig. 4a), which has a lower spatial resolution of $\sim 1 \mu \mathrm{m}$.

\subsubsection{Dissolution-reprecipitation versus decarbonation}

Because the incorporation of ${ }^{18} \mathrm{O}$ into the calcite crystal structure is not likely to happen via solid-state diffusion, we will discuss possible fluid-mediated exchange mechanisms that may have produced the isotope enrichment in the newly 
formed grains. An alternative mechanism to solid-state diffusion, which has been shown to result in ${ }^{18} \mathrm{O}$ incorporation from enriched water into Ca-carbonates during static experiments (Perdikouri et al., 2011), is the direct dissolution of calcite into the pore fluid followed by its reprecipitation during the experiments. Dissolution of calcite is dependent on temperature, pressure, and $\mathrm{pH}$, showing an overall trend of reduced solubility with increasing temperature (Ellis, 1959), referred to as retrograde solubility. Dissolution of $\mathrm{CaCO}_{3}$ in water occurs by the reaction (Sjöberg, 1976):

$$
\mathrm{CaCO}_{3(\mathrm{~s})}+\rightleftarrows \mathrm{Ca}^{2+}{ }_{(\mathrm{aq})}+\mathrm{CO}_{3}{ }^{2-}{ }_{(\mathrm{aq})}
$$

Dissolution of calcite would thus allow the release of the carbonate ion after which it can undergo isotopic exchange by $\mathrm{CO}_{2 \text { (aq) }}$ hydration or hydroxylation as part of the dynamic equilibrium that exists between different carbonate species in solution, shown in reaction [2] (Mills and Urey, 1940; Geisler et al., 2012).

$$
\begin{aligned}
\mathrm{CO}_{2(\mathrm{aq})}+\mathrm{H}_{2}{ }^{18} \mathrm{O} & \rightleftarrows \mathrm{H}_{2} \mathrm{C}^{16} \mathrm{O}_{2}{ }^{18} \mathrm{O}_{(\mathrm{aq})} \\
& \rightleftarrows \mathrm{HC}^{16} \mathrm{O}_{2}{ }^{18} \mathrm{O}_{(\mathrm{aq})}+\mathrm{H}^{+}{ }_{(\mathrm{aq})} \\
& \rightleftarrows \mathrm{C}^{16} \mathrm{O}_{2}{ }^{18} \mathrm{O}^{2-}{ }_{(\mathrm{aq})}+2 \mathrm{H}^{+}(\mathrm{aq})
\end{aligned}
$$

Subsequent reaction of the carbonate ion with water forms bicarbonate and both can bind with the available $\mathrm{Ca}^{2+}$ ion to re-precipitate calcite (Edvardsen, 1999):

$$
\begin{array}{lr}
\mathrm{Ca}^{2+}{ }_{(\mathrm{aq})}+\mathrm{CO}_{3}{ }^{2-}(\mathrm{aq}) & \rightleftarrows \mathrm{CaCO}_{3(\mathrm{~s})} \quad\left(7.5<\mathrm{pH}_{\text {water }}<8\right) \\
\mathrm{Ca}^{2+}{ }_{(\mathrm{aq})}+\mathrm{HCO}_{3(\mathrm{aq})} \rightleftarrows \mathrm{CaCO}_{3(\mathrm{~s})}+\mathrm{H}^{+}{ }_{(\mathrm{aq})} \quad\left(\mathrm{pH}_{\text {water }}>8\right)
\end{array}
$$

Previous static experiments at $200{ }^{\circ} \mathrm{C}$ demonstrate that the dissolutionreprecipitation reactions of $\mathrm{Ca}$-carbonates can result in carbonate-isotopologue distributions that reflect almost $90 \%{ }^{18} \mathrm{O}$ incorporation and estimate that the isotope exchange between $\left[\mathrm{CO}_{3}{ }^{2-}\right]_{(\mathrm{aq})}$ and $\mathrm{H}_{2}{ }^{18} \mathrm{O}$ requires a reaction time of $t \sim 0.9$ seconds (Perdikouri et al., 2011). This extrapolation is consistent with an extrapolation of the time taken for a carbonate-rich solution to reach equilibrium with $\mathrm{H}_{2}{ }^{18} \mathrm{O}$ from Geisler et al. (2012), indicating that at the predicted highest, buffered experimental temperatures, isotopic equilibrium with the pore fluids should be reached in less than a second. An isotopologue distribution that is dominated by the $\mathrm{C}^{18} \mathrm{O}^{32-}$ species would be expected if calcite dissolution-reprecipitation resulted in the observed ${ }^{18} \mathrm{O}$ enrichment based on the results of the two past studies. However, the results of Raman spectroscopy in Figure 6 and 8, show that the $\mathrm{C}^{16} \mathrm{O}_{2}{ }^{18} \mathrm{O}^{2}$ - isotopologue exhibits the highest abundance. Even at the temperature measured in the experiment $\left(136^{\circ} \mathrm{C}\right.$ and $207^{\circ} \mathrm{C}$ ), we would expect a higher content of the $\mathrm{C}^{16} \mathrm{O}^{18} \mathrm{O}_{2}{ }^{2-}$ isotopologue than the one observed. Unlike the experiments of Perdikouri et al. (2011), the system tested here first requires the dissolution of calcite prior to $\mathrm{O}$-isotope exchange. The 
dissolution of calcite is expected to be the rate-limiting step for a dissolutionreprecipitation mechanism as this should be slow at the elevated temperatures because of the retrograde solubility. Hence, the isotopologue distribution and the 65 $\%$ reacted volume in the seismic experiments indicate that a different mechanism for calcite isotope exchange is dominant.

The high abundance of the $\mathrm{C}^{16} \mathrm{O}_{2}{ }^{18} \mathrm{O}^{2-}$, independent of the type of deformation experiment i.e., high-, or low-velocity deformation, suggests that a preferred reaction pathway is applicable to both regimes. With the additional presence of portlandite in the high-velocity experiment, amorphous $\mathrm{C}$ in both and the high amount of reacted material, all the evidence points to calcite decarbonation as the main mechanism for calcite breakdown. At standard pressure and under dry, static conditions the decarbonation of calcite only occurs at temperatures starting at $600{ }^{\circ} \mathrm{C}$ (Rodriguez-Navarro et al., 2009). The following reaction illustrates the endothermic decarbonation reaction:

$$
\mathrm{CaCO}_{3(\mathrm{~s})} \rightleftarrows \mathrm{CO}_{2(\mathrm{~g})}+\mathrm{CaO}_{(\mathrm{s})} \quad\left(\Delta H^{0}{ }_{298 \mathrm{~K}}=+178 \mathrm{~kJ} \mathrm{~mol}^{-1}\right)[5]
$$

that results in the release of $\mathrm{CO}_{2}$ and the formation of lime $(\mathrm{CaO})$. However, $\mathrm{CO}_{2}$ release has been observed during ball milling of dry calcite powder at room temperature (Martinelli and Plescia, 2004). The ball milling experiments by Martinelli and Plescia (2004) follow up on preliminary experiments by Dickinson et al. (1991) who detected $\mathrm{CO}_{2}$ emission in three-point-bend fracture tests of calcite, leading Martinelli and Plescia (2004) to infer that mechanical decarbonation was the source of the $\mathrm{CO}_{2}$ emission. Both studies suggest that mechanical decarbonation may occur also at lower macroscopic temperatures although, as discussed previously, local temperatures at grain contacts could be elevated compared to the bulk measurements. Because bulk experiment temperatures of $136{ }^{\circ} \mathrm{C}$ and $207{ }^{\circ} \mathrm{C}$ measured here are below the decarbonation temperature of $600{ }^{\circ} \mathrm{C}$, mechanical decarbonation is a probable mechanism for calcite breakdown in the seismic and subseismic experiments. The resulting lime from reaction [5] is highly reactive and can react immediately ( $t=10$ picoseconds, (Manzano et al., 2012)) with water to hydrate lime to portlandite $\left(\mathrm{Ca}(\mathrm{OH})_{2}\right)$ by (Kudłacz and Rodriguez-Navarro, 2014):

$$
\mathrm{CaO}_{(\mathrm{s})}+\mathrm{H}_{2} \mathrm{O}_{(\mathrm{l})} \rightarrow \mathrm{Ca}(\mathrm{OH})_{2(\mathrm{~s})} \quad\left(\Delta H^{0}{ }_{298 \mathrm{~K}}=-109 \mathrm{~kJ} \mathrm{~mol}^{-1}\right) \quad[6]
$$

Because of its high, negative formation enthalpy reaction [6] also does not require additional energy input, e.g., high temperatures, to occur. There are two proposed mechanisms to hydrate lime where a) hydration occurs via $\mathrm{CaO}$ dissolution in water and subsequent nucleation and growth of $\mathrm{Ca}(\mathrm{OH})_{2}$, and b) via vapor phase 
hydration which is assumed to be a solid-state mechanism (Kudłacz and RodriguezNavarro, 2014; Pesce et al., 2017). Both would result in the incorporation of ${ }^{18} \mathrm{O}$ from the pore fluid into portlandite but according to the authors, mechanism a) is currently favoured and would provide a fast, solution-mediated exchange mechanism. Subsequent carbonation of portlandite with $\mathrm{CO}_{2}$ can back-react to calcite via the reaction [7]:

$$
\mathrm{Ca}(\mathrm{OH})_{2(\mathrm{~s})}+\mathrm{CO}_{2(\mathrm{~g})} \rightleftarrows \mathrm{CaCO}_{3(\mathrm{~s})}+\mathrm{H}_{2} \mathrm{O}_{(\mathrm{aq})} \quad\left(\Delta H^{0}{ }_{298 \mathrm{~K}}=-93 \mathrm{~kJ} \mathrm{~mol}^{-1}\right)
$$

As incorporation of the water molecule during lime hydration produces portlandite with the composition $\left(\mathrm{Ca}^{16} \mathrm{O}^{18} \mathrm{OH}_{2}\right)$, the carbonation reaction can result in calcite with or without the presence of the $\mathrm{C}^{16} \mathrm{O}_{2}{ }^{18} \mathrm{O}^{2-}$ isotopologue. Thus, the decarbonation-carbonation mechanism can explain the higher abundance of the $\mathrm{C}^{16} \mathrm{O}_{2}{ }^{18} \mathrm{O}^{2-}$ in the newly formed calcite. The formation of the $\mathrm{OH}$-isotopologue within portlandite from reaction [6] could possibly be verified as Black et al. (2006) showed that ${ }^{18} \mathrm{O}$ incorporation into portlandite results in a $v 1(\mathrm{OH})$-stretching band position shift to lower wavenumbers. However, we unfortunately could not compare portlandite spectra under the same Raman measurement conditions because no portlandite was detected in the control sample LHV982, run at $v=1 \mathrm{~m} / \mathrm{s}$ and $\sigma_{n}=2$ $\mathrm{MPa}$ with deionised water, potentially due to its small size and distribution. The formation of isotopologues with higher isotopic enrichment via the decarbonation mechanism requires that the $\mathrm{CO}_{2(\mathrm{~g})}$ released also dissolves into the pore fluid so that it too can incorporate ${ }^{18} \mathrm{O}$ during hydration or hydroxylation (reaction [2]). This enriched, dissolved carbonate could exsolve to form $\mathrm{C}^{16} \mathrm{O}^{18} \mathrm{O}(\mathrm{g})$, which subsequently reacts directly with portlandite, or with $\mathrm{Ca}^{2+}$ ions released from a small amount of calcite, lime or portlandite dissolution to form a more enriched calcite. Together with the estimates for lime hydration in reaction [6] of $t=10$ picoseconds by Manzano et al. (2012) the approximated reaction times demonstrate that fluid-mediated isotope exchanges are viable and fast mechanisms to incorporate ${ }^{18} \mathrm{O}$ into the crystal structure of calcite. We suggest that the most likely reaction pathway to incorporate ${ }^{18} \mathrm{O}$ is by the dissolution of decarbonation products because we detect portlandite in the $20 \mathrm{~s}$ duration high-velocity samples (Fig. 5c). Considering that formation of portlandite occurs via fluid precipitation, this would require a fast isotope-exchange mechanism according to reaction [7]. Overall, reactions [1] - [7] suggest that the formation of ${ }^{18} \mathrm{O}$-calcite did not occur as a solid-state process but likely as sequential, multistage dissolution-reprecipitation reaction, starting with the dissolution of decarbonation products. 


\subsubsection{Amorphous carbon formation via triboelectrochemical processes}

We have discussed possible formation pathways for the oxygen-isotope exchange and will continue to discuss possible formation mechanisms of the amorphous carbon (a-c) we detect throughout the experiments. A comparison of samples embedded in epoxy and those without epoxy (see appendix) highlight that the a-c is not a result of sample preparation but an inherent reaction product of the experiments.

Decarbonation of calcite via reaction [5] produces $\mathrm{CO}_{2}$, rather than a reduced form of carbon, including the a-c observed. Consequently, the presence of a-c requires that the $\mathrm{CO}_{2}$ produced during decarbonation is reduced via an additional reaction that occurs during the experiments. Given that a-c formed in both the low-, and high-velocity experiments, the mechanism to form $\mathrm{C}_{(\mathrm{s})}$ does not appear to have a high energetic barrier or a strong temperature dependence, so the mechanism should be active in both shearing regimes. As the reactants in all deformation experiments are limited to calcite and water, a reducing material, e.g., a metal should be present in the system for the $\mathrm{CO}_{2}$ reduction reaction to occur. Whereas the pistons in the high-velocity experiments are made of a Ti-alloy and are in full contact with the sample, in the low-velocity experiments the a-c is concentrated within the shear boundary layer. Although $\mathrm{CO}_{2}$ can oxidise Ti to form $\mathrm{TiO}$ and reduced $\mathrm{C}$, this requires high temperatures and timescales of hours (Menzies and Strafford, 1975). Hence, it is unlikely that the apparatus itself can act as the reductant for the $\mathrm{CO}_{2}$ reduction redox pair. Amorphous carbon has been observed previously in high-velocity friction experiments when a reducing gas environment $\left(\mathrm{H}_{2}\right)$ was present (Oohashi et al., 2014). In this case, the $\mathrm{H}_{2}$ gas enabled the reduction of $\mathrm{CO}_{2}$ to methane, which was proposed to further react to form a solid a-c phase (Oohashi et al., 2014):

$$
\mathrm{CO}_{2(\mathrm{~g})}+2 \mathrm{H}_{2(\mathrm{~g})} \rightarrow \mathrm{C}_{(\mathrm{s})}+2 \mathrm{H}_{2} \mathrm{O}_{(\mathrm{g})} \quad\left(\Delta H^{0_{298 K}}=-90 \mathrm{~kJ} \mathrm{~mol}^{-1}\right) \quad \text { [8] }
$$

In the experiments conducted here, no strongly reducing gas environment was introduced. Therefore, if we assume that syn-deformational reduction of $\mathrm{CO}_{2}$ by hydrogen in a wet experiment remains a viable mechanism, it is important to identify possible mechanisms by which hydrogen (gas) can be produced in-situ during deformation. In support of our hypothesis, $\mathrm{H}_{2}$ emission was measured during deformation experiments by e.g., Spagnuolo et al. (2015).

Water can be split into hydrogen and oxygen gas using electrolysis. This procedure is typically performed by a redox reaction promoted by applying an 
electric potential between an anode and a cathode submerged in water, where the overall reaction can be written as:

$$
2 \mathrm{H}_{2} \mathrm{O}_{(\mathrm{l})}+\operatorname{energy}\left(\Delta G^{0}\right) \rightarrow 2 \mathrm{H}_{2(\mathrm{~g})}+\mathrm{O}_{2(\mathrm{~g})}
$$

The Gibbs free energy $\left(\Delta \mathrm{G}^{0}\right)$ for reaction [9] can be calculated by

$$
\Delta G^{0}=-n F E^{0}
$$

where $n=4$ for the formation of $2 \mathrm{H}_{2}$ from $2 \mathrm{H}_{2} \mathrm{O}, F$ is the Faraday constant $(96485.3$ $\mathrm{C} / \mathrm{mol}$ ) and $E^{0}$ is the standard cell potential of water electrolysis with $E^{0}=-1.229 \mathrm{~V}$. For one mol of water $\Delta G^{0}=237.16 \mathrm{~kJ} / \mathrm{mol}$. The threshold energy $E_{t}$ can be determined by:

$$
E_{t}=\frac{\Delta G^{0}\left(\mathrm{H}_{2} \mathrm{O}\right)}{2 N_{A}}
$$

where $\mathrm{N}_{\mathrm{A}}=6.023 \times 10^{23}$ (Avogadro's number), resulting in $E_{t}=1.97 \times 10^{-19} \mathrm{~J} \approx 1.23 \mathrm{eV}$. This approximation shows that the electric potential required to split water at $25^{\circ} \mathrm{C}$ and $\mathrm{pH}=7$ is relatively low. As the gases form via the incorporation of electrons during redox half reactions of $\mathrm{H}^{+}$or $\mathrm{OH}^{-}$at the anode and cathode, the number of electrons that need to be available at a surface is also low. Temperature can facilitate the hydrolysis of water by supplying a part of the energy needed through heat, thus reducing the required electrical potential (Hauch et al., 2008). For example, compared to electrolysis at $80{ }^{\circ} \mathrm{C}(100 \%)$, the required cell potential is reduced to $82 \%\left(150{ }^{\circ} \mathrm{C}\right), 74 \%\left(208^{\circ} \mathrm{C}\right)$ and $69 \%\left(264^{\circ} \mathrm{C}\right)$. In addition, the presence of electrolytes, e.g., dissolved ions, can also increase the efficiency of electrolysis. Thus, higher temperatures related to asperity contacts, higher bulk temperatures during experiments and the dissolution of solids may enhance electrolysis during deformation.

In the experiments studied here, the traditional redox pairs that are used for electrolysis are not present. However, there are in-situ mechanisms that produce an electrical current from otherwise insulating and non-redox active materials that are related to deformation. For example, the application of mechanical stress on minerals such as quartz is known to create piezoelectricity. It has been shown that quartz fibres submerged in water can lead to direct-water-splitting via a piezoelectrochemical effect to produce hydrogen and oxygen gas (Hong et al., 2010). This effect appears to be so efficient that it has been patented as a possible fuel production mechanism (Xu et al., 2013). If the solid phases present in the experiments can also produce this effect, then they could create the potential required for water electrolysis reactions. Minerals that exhibit piezoelectric effects, including quartz, 
belong to the non-centrosymmetric group of crystal structures. Despite calcite belonging to the group of centrosymmetric minerals, preliminary research on calcite shows that it too can have a piezoelectricity in the direction of the c-axis, (Guerin et al., 2018). The research by Guerin et al. (2018) yields a piezoelectric constant $d x z$ between $2-7 \times 10^{-14} \mathrm{C} / \mathrm{N}$ for different types of $\mathrm{CaCO}_{3}$ specimens (e.g., Iceland spar calcite and mollusc shells). We can estimate the potential voltage output $V_{c}$ of calcite along the c-axis direction under a normal stress $P$ of $4 \mathrm{MPa}$ (high-velocity experiments) via:

$$
V_{c}=P \frac{d_{x z} \cdot t}{\varepsilon_{c c^{\prime}} \varepsilon_{0}}
$$

where $t$ is the size of a calcite particle (here $28 \mu \mathrm{m}), \varepsilon_{c c}$ the relative permittivity of calcite and $\varepsilon_{0}$ the permittivity of free space $\left(8.85 \times 10^{-12} \mathrm{~F} / \mathrm{m}\right)$. Depending on $\varepsilon_{c c}$, which varies in the literature between $\sim 2.5$ and 9.1 (Guerin et al., 2018; Lebron et al., 2004), we obtain a $V_{c}$ between $0.03-0.35 \mathrm{~V}$. For the sake of argument, we assume that $V_{c}$ is the cell potential $E^{0}$. Utilising Eq. 4 with $E^{0}=0.35 \mathrm{~V}$ we obtain $\Delta G^{0} \approx 67.5 \mathrm{~kJ} / \mathrm{mol}$ equivalent to a threshold energy $E_{t}=0.35 \mathrm{eV}$ (Eq. 5), which is insufficient to split water using a piezoelectric effect in calcite. In addition, the decarbonation products are not expected to be piezoelectric as they also belong to the centrosymmetric space groups. Therefore, it is unlikely that piezoelectric effects are present in the highvelocity experiments. When we now consider a normal stress of $50 \mathrm{MPa}$ (lowvelocity experiments) Eq. 6 can yield up to $V_{c}=4.4 \mathrm{~V}$, which can produce a threshold energy of $E_{t}=4.37 \mathrm{eV}$ which makes the piezoelectric effect a potential mechanism to drive electrolysis during low-velocity deformation. Amorphous carbon that is produced in the low-velocity experiments under $T=92{ }^{\circ} \mathrm{C}$ at normal stresses 25 times higher than the high-velocity experiments (2 $\mathrm{MPa}$ vs. $50 \mathrm{MPa}$ ) shows a clear correlation between a-c formation efficiency and areas of high particle interaction, e.g., boundary shear.

An alternative mechanism to generate an electric potential that is also independent of material redox activity is triboelectrical charging. As tribological charging results from surfaces rubbing (Pan and Zhang, 2019), these areas of high particle interaction would be optimal locations for the production of triboelectricity. Small grains result in a high total number of contact events in comparison to large surfaces. In addition, with decreasing grain size the charge capacity per unit mass increases (Pan and Zhang, 2019), and a large electric potential would be expected in our experiments due to the use of $28 \mu \mathrm{m}$ particles and the formation of smaller grains 
during deformation. Indeed, deformation experiments of simulated, monomineralic fault gouges using quartz (Takeuchi and Nagahama, 2002) or soda-lime glass beads (Leeman et al., 2014) have demonstrated that significant surface charges can be generated via triboelectrification. Here, asymmetric contact theory is invoked to explain the build-up of charge, where non-equilibrium surface states on otherwise identical surfaces drive the transfer of charge from one surface to another. Leeman et al. (2014) report that in addition to the potential of 1-4 V related to individual stickslip events, a potential of up to $250 \mathrm{~V}$ was built up during an entire experimental run. Besides, the amount of individual stick-slip events showed a strain-rate dependence generating a higher potential at higher strain rates. Utilising $4 \mathrm{~V}$ as cell potential $E^{0}$, one stick-slip event would produce $\Delta G^{0} \approx 771.9 \mathrm{~kJ} / \mathrm{mol}$ equivalent to a threshold energy $E_{t} \approx 4 \mathrm{eV}$ (Eq. 5) of energy, which is enough to spilt water. Formation of decarbonation products could also assist with triboelectrification as the frictional contact between different solids is known to be effective at creating charged surfaces via ion transfer in insulator-insulator systems (Pan and Zhang, 2019). Measurements of triboelectric charging in mineralogical systems are typically carried out under dry conditions. Work on an organic-metal system has demonstrated that increasing water layer thickness at the insulator surface can increase the rate of charge build-up (Wiles et al., 2004). This behaviour is related to the presence of charge-exchanging groups at the surface, which are proposed to increase during the reconstruction of $\mathrm{pH}$-sensitive surfaces. Whether our experiments have enough water to generate a continuous film through which charge can be dissipated, or enough charge can be retained at a surface to generate electrolysis reactions requires a different experimental approach to the one taken here.

It is also possible that the presence of an electric potential could directly reduce $\mathrm{CO}_{2}$ to carbon based on the breakdown field and surface charge density reported by Muto et al. (2008). The formation enthalpy of $\mathrm{CO}_{2}$ is $\Delta_{\mathrm{f}} \mathrm{H}^{0}=393.51 \mathrm{~kJ} / \mathrm{mol}$ (Cox et al., 1989), which is approx. $6.55 \times 10^{-19} \mathrm{~J} \approx 4.08 \mathrm{eV}$. Accordingly, breaking one mol of $\mathrm{CO}_{2}$ into carbon and oxygen requires the same amount of energy. Based on our approximations above and the observations of Leeman et al. (2014) that a potential can be built up over the course of an experiment that far exceeds this boundary ( $250 \mathrm{~V}$ was measured), it may be possible to directly reduce $\mathrm{CO}_{2(\mathrm{~g})}$ to carbon with an electric potential created during slip. A potential large enough to directly reduce $\mathrm{CO}_{2}$ to $\mathrm{C}_{(\mathrm{s})}$ could explain why amorphous carbon also forms 
occasionally in dry experiments (e.g., Delle Piane et al., 2017). Partial reduction of $\mathrm{CO}_{2}$ to $\mathrm{CO}$ during electrolysis could also be possible (Benson et al., 2009) by

$$
\mathrm{CO}_{2}+2 \mathrm{H}^{+} \rightarrow \mathrm{CO}+2 \mathrm{H}_{2} \mathrm{O} \quad\left(E^{0}=-0.53 \mathrm{~V}\right) \quad[10]
$$

which would require less energy and is also a typical reactant to form methane via further reduction in the presence of hydrogen. Regardless of the possible mechanism for $\mathrm{CO}_{2}$ reduction, the presence of a-c, absence of an externally added reducing agent (e.g., $\mathrm{H}_{2}$ gas) in the initial experimental setup point towards an interesting and unexpected redox chemistry occurring during shear. Testing the viability of the pathways proposed here warrants further exploration as they will be critical not only to understand the a-c formation process in these experiments, but also to explain the natural observations in Chapter 1.

\subsubsection{Possible weakening mechanisms}

NanoSIMS and Raman spectroscopic analyses show that recrystallisation and accompanied ${ }^{18} \mathrm{O}$-incorporation affected about $65 \%$ of the calcite volume across the entire gouge thickness in the high-velocity experiments. This distribution implies that over half of the calcite gouge did not exist as crystalline calcite during high-velocity deformation but underwent a multitude of phase transformations and fluid-assisted reactions. The nearly instantaneous transition from crystalline calcite to a mixture of partially transient phases, ${ }^{18} \mathrm{O}$-enriched calcite and formation of amorphous carbon has severe consequences for the mechanical behaviour of the gouge. In the following, we will discuss potential weakening mechanisms based on the microstructural and geochemical results.

$\mathrm{CO}_{2}$ released from reaction [1] could either dissolve in the pore fluid or stay as a separate gas phase. In both cases, the increased temperature during the experiments could lead to thermal pressurisation of the pore fluid or the formation of a gas layer leading to volume expansion and possible slip with ultra-low friction (Hu et al., 2019). Thermal pressurisation would result in a reduction of effective stress by pressuring the pore fluid through thermal expansion caused by frictional heating of the confined pore space (Rice, 2006). However, because of the delay between the onset of sample dilatation (6-m slip distance) and the drop in friction coefficient $\left(\sigma_{n}=2 \mathrm{MPa}\right)$ it is likely that the $\mathrm{CO}_{2}$ release and subsequent thermal pressurisation of the pore fluid at the onset of weakening is insufficient to explain the here observed dynamic weakening (Fig. 2b). In contrast to experiments at $2 \mathrm{MPa}$, the dilatation of experiments run at $4 \mathrm{MPa}$ show a near-instantaneous volume 
increase and a $D_{w}$ that is $0.7-1.0 \mathrm{~m}$ shorter, as well as a reduction of $\mu_{s s}$ from 0.16 to 0.1. These observations could be explained by a $\sigma_{n}$-dependent increase in decarbonation rate, hence $\mathrm{CO}_{2}$ emission adding to thermal pressurization. Higher temperatures of $\Delta T=43^{\circ} \mathrm{C}$ are reached at $\sigma_{n}=4 \mathrm{MPa}$ prior to fluid-assisted thermal buffering may also add to a pressurization effect. Hence, the reduced $\mu_{\text {ss }}$ and shorter $D_{w}$ at $4 \mathrm{MPa}$ could be explained by an increased contribution of thermal pressurization, warranting additional experimental investigations.

In addition to thermal pressurization, it is critical to evaluate the impact of the observed formation of $\mathrm{a}-\mathrm{c}$ and portlandite on the rheological fault gouge behaviour. The $\mu_{s s}$ value of a-c of 0.15 at $v=1.3 \mathrm{~m} / \mathrm{s}$ (Oohashi et al., 2011) is close to the measured friction coefficient of $\mu_{s s}=0.16$ during the wet deformation experiment performed here at $2 \mathrm{MPa}$. The steady-state friction coefficient for a-c determined by Oohashi et al. (2011) shows no correlation with varying normal stress. However, the steady-state friction coefficient shows a strong strain-rate dependence, where deformation at e.g., $v=1 \mathrm{~mm} / \mathrm{s}$, results in $\mu_{s s}=0.56$ (Oohashi et al., 2011). The nearidentical $\mu_{s s}$ values of our study and Oohashi et al. (2011) may indicate that amorphous carbon contributes to the syn-deformational fault friction over a wide range of slip rates (from $0.1 \mu \mathrm{m} / \mathrm{s}$ to $\mathrm{m} / \mathrm{s}$ ). However, the slip-weakening distance for pure amorphous carbon reported by Oohashi et al. (2011) is considerably long than in our experiments. The strain-rate dependence of amorphous carbon implies that a-c may form during pre-shearing or immediately ahead of the high-velocity deformation phase. If we consider the low-velocity experiments as representative for the pre-shear stage, then a-c forms already during the $1 \mathrm{~m}$ pre-shearing. The resulting mixture of calcite and a-c would exhibit no weakening behaviour, similar to the strain-rate dependent behaviour of a-c described by Oohashi et al. (2011). However, when the experiments are speeding up to $v=1 \mathrm{~m} / \mathrm{s}$, the full impact on the strain-rate dependent behaviour on a-c and gouge friction leads to a severe drop in friction and should produce a strong dynamic weakening response. The strain-rate dependent friction response of a-c may be the main factor why our low-velocity experiments show no weakening despite the high concentration of a-c inside the boundary shear. If the formation of a-c is sponsored via triboelectrical mechanisms, a higher amount of mechanical force at higher velocities will result in a larger electric potential and higher $\mathrm{H}_{2}$ production. In combination with an increased decarbonation rate, the increased formation of a-c at higher velocities will weaken the fault gouge. 
Frictional properties of portlandite show a $\sigma_{n}$-dependence and a velocity strengthening behaviour at low sliding velocities. The steady-state friction coefficients at low velocities $(<1 \mathrm{~mm} / \mathrm{s})$ are $\mu_{s s}=0.3$ at $\sigma_{n}=50 \mathrm{MPa}$ and $\mu_{s s}=0.6$ at $\sigma_{n}$ $=2 \mathrm{MPa}$ (Carpenter et al., 2015). Velocity steps performed by Carpenter et al. (2015) show an increase in $\mu$ from $\mu=0.55$ at $v=0.3 \mu \mathrm{m} / \mathrm{s}$ to $\mu=0.65$ at $v=1 \mathrm{~mm} / \mathrm{s}$. To evaluate if portlandite contributes to the drop in friction we also need to consider if portlandite formed by solid-state hydration of lime or by lime dissolution and portlandite precipitation, as discussed in Section 4.2. This consideration is important because solid-state hydration is not fast enough to form portlandite during the highvelocity experiments and hence, the precipitation of portlandite from the fluid would result in small portlandite crystals, as crystals start to nucleate. Because aggregates with small grain sizes tend to exhibit a lower friction coefficient, we would expect a minor contribution of small portlandite crystals to the overall friction. Besides, the $\sigma_{n}$-dependence and a velocity strengthening behaviour of portlandite is not in favour of portlandite contribution to a reduction in friction during seismic deformation. Some portion of portlandite may even form at a later stage when the experiment decelerates and may not contribute to the initial weakening.

When the combined volume of low viscosity phases increases, fault friction should be controlled by the phase mixture rather than by calcite alone. The fault would then progress from a grain-supported structure to a matrix-supported structure where grains inside the fault gouge are fully covered with the mixture of a-c and transient phases such as the phases from reactions [1] to [8]. With the temperature-dependent reduction of water viscosity from $10^{-3} \mathrm{~Pa}^{*} \mathrm{~S}$ at $20^{\circ} \mathrm{C}$ to $1.8 \times 10^{-}$ ${ }^{4} \mathrm{~Pa}^{*} \mathrm{~S}$ at $150{ }^{\circ} \mathrm{C}$ (Kestin et al., 1978) it is plausible that the phase mixture of a-c, pore fluid, decarbonation products and transient reaction products may exhibit an even lower friction coefficient compared to pure a-c. This assumption is supported by the difference in slip-weakening distance between our experiments $\left(D_{w}=1.52-2.47 \mathrm{~m}\right)$ and pure a-c $\left(D_{\mathrm{w}}>5 \mathrm{~m}\right)$ (Oohashi et al., 2011) suggesting that the dynamic weakening is not only a consequence of a-c formation, but that other phases need to contribute to the dynamic weakening to decrease $D_{w}$. The rapid increase in content of lubricating phases such as a-c, pore fluid, gas and transient reactions products would turn the fault gouge into a suspension where interparticle contact is minimized, resulting in the breakdown of the load-bearing framework, and thus promoting a fluidization effect. Fluidisation is commonly achieved by streaming a 
gas or a liquid through an unconsolidated, porous medium. In our experiments, the transient phase mixture and $\mathrm{CO}_{2}$ would represent the gas and fluid, and the loss of interparticle contact would reduce the internal friction and lead to a quasi-fluid like behaviour with reduced viscosity (Di Felice, 1995). As a consequence of calcite breakdown and fluidisation, wet calcite deformation cannot be described by solidstate deformation mechanisms, in contrast to the suggestions by e.g., De Paola et al., 2015 and Pozzi et al., 2019. We suggest that transient reaction phases and a-c, as well as a pressurized pore fluid, promote a fluidisation effect resulting in a low friction coefficient.

In conclusion, the mechanical results coupled to microstructural and geochemical observations suggest that several, intrinsically linked chemically driven mechanisms are contributing to the dynamic weakening at the onset of highvelocity deformation in fluid-present calcite fault gouge. In contrast, when such reactions also take place at low sliding velocity, they do not affect frictional behaviour significantly because the load-bearing framework of calcite grains remains present.

\subsubsection{Crystal deformation and dislocation structures}

Defect structures observable using TEM analysis show that the large survivor grains from the high-velocity experiments have experienced significant mechanical force. This is not the case for the nanograins found in the matrix, which show minimal defect structures. Thus, the smaller grains grew in the new physical and chemical conditions imparted upon the system due to deformation consistent with the isotope analysis. Crystal-orientation measurements of the survivor grains indicate the activity of $\{\overline{1} 018\}<40 \overline{4} 1>$ e-twinning and the activation of the $(0001)<\overline{1} 2 \overline{1} 0>$ glide system (Fig. 5 c). Subgrain misorientation rotations around $<\mathrm{m}>$ are consistent with the presence of tilt boundaries consisting of $(0001)<\overline{1} 2 \overline{1} 0>$ edge dislocations (Fig. 5d). In an initial study by De Bresser and Spiers (1997), the $(0001)<\overline{1} 2 \overline{1} 0>$ slip system is considered of minor importance. But the observation of the $(0001)<\overline{1} 2 \overline{1} 0>$ CPO is in agreement with previous research (Smith et al., 2013; Verberne et al., 2013; Delle Piane et al., 2017; Kim et al., 2018; Demurtas et al., 2019; Pozzi et al., 2019) and the results of Chapter 2. This highlights a discrepancy for the temperatures associated with this slip system as the detailed calcite single crystal experimental study by De Bresser and Spiers (1997) indicates the $(0001)<\overline{1} 2 \overline{1} 0>$ slip system to be active in the temperature range of $600-800{ }^{\circ} \mathrm{C}$ and at $v=5 \times 10^{-5} \mathrm{~s}^{-1}$. This 
temperature range contradicts the syn-deformational temperature measurements conducted here, which provide a direct constraint on the bulk peak temperature of $136{ }^{\circ} \mathrm{C}$ and $207^{\circ} \mathrm{C}$ (Fig. 2c). Unfortunately, the solid-state ${ }^{18} \mathrm{O}$ diffusion length into the survivor grains is too short to be resolved during the $20 \mathrm{~s}$ high-velocity experiment even with estimated temperatures at $600{ }^{\circ} \mathrm{C}$, otherwise we could have used this as an in-situ, local temperature estimate. Therefore, we cannot rule out that the local, grain-scale temperatures may be higher than the measured bulk temperatures. Based on our predictions of a buffered temperature, the discrepancy could indicate that the presence of a pore fluid could influence the temperature range at which slip systems are active.

\subsection{Conclusion}

Deformation of calcite at sub-seismic (low) and seismic (high) velocities under hydrous conditions results in sequential multistage dissolution and precipitation reactions. Comparison between dry and wet deformation experiments show a strong difference in slip-weakening distance and steady-state weakening for the wet experiments. Mechanical decarbonation during deformation is expected to form lime $(\mathrm{CaO})$ and releases $\mathrm{CO}_{2}$ whereupon both molecules interact with the available pore fluid enriched in $\mathrm{H}_{2}{ }^{18} \mathrm{O}$ to ultimately form new calcite grains. These calcite grains are marked by a carbonate group $\left(\mathrm{CO}^{2-}\right)$ containing the ${ }^{18} \mathrm{O}$-isotope from the pore fluid, resulting in the development of the three isotopologues $\mathrm{C}^{16} \mathrm{O}_{2}{ }^{18} \mathrm{O}^{2-}, \mathrm{C}^{16} \mathrm{O}^{18} \mathrm{O}_{2}{ }^{2-}$ and $\mathrm{C}^{18} \mathrm{O}_{3}{ }^{2-}$. The formation of ${ }^{18} \mathrm{O}$-calcite demonstrates that isotope exchange proceeds through the pore fluid and not through solid-state replacement mechanisms. Our upper-limit approximation of the ${ }^{18} \mathrm{O}$-diffusion distance at $600{ }^{\circ} \mathrm{C}$ of $3 \mathrm{~nm}$ on the timescale of the performed experiments illustrates the contrast to the euhedral ${ }^{18} \mathrm{O}$-calcite of $50 \mathrm{~nm}$ diameter (Fig. 3c). We estimate that about $65 \%$ of the deformed material in the high-velocity experiments undergoes a phase transformation and thus reacts with the available pore fluid. Amorphous carbon forms most likely by reducing $\mathrm{CO}_{2}$ with hydrogen (gas) which results from electrolysis of water via a triboelectric effect during calcite deformation. Because we observe the same reaction products during low-, and high- velocity experiments, we propose that the reactions to form amorphous carbon may be mainly chemically driven and do not need a high amount of thermal energy input to drive the reactions. A mixture of amorphous carbon, pore fluid and $\mathrm{CO}_{2}$ may be responsible for the sharp drop in friction coefficient and could be the key weakening factor. The 
resulting breakdown of the load-bearing framework leads to a fluidisation effect, where grains lose contact and interparticle friction is dominated by the transient phase mixture. Our research demonstrates that at the time of deformation over $65 \%$ of the former calcite fault gouge was not deforming as calcite. Stable-isotope labelling demonstrates that the observation of only mechanical data and postmortem microstructures of deformation experiments leaves a knowledge gap of the transient reactions during carbonate deformation. This research may have largescale implications for current microphysical models, considering that about $65 \%$ of the granular fault material was affected by the sequential multistage dissolution and precipitation reactions.

\section{References}

Bachmann F., Hielscher R., Schaeben H., 2011. Grain detection from 2d and 3d EBSD data-Specification of the MTEX algorithm. Ultramicroscopy. 111, 1720-1733.

Benson E.E., Kubiak C.P., Sathrum A.J., Smieja J.M., 2009. Electrocatalytic and homogeneous approaches to conversion of $\mathrm{CO}_{2}$ to liquid fuels. Chemical Society Reviews. 38, 89-99.

Black L., Breen C., Yarwood J., Deng C., Phipps J., Maitland G., 2006. Hydration of tricalcium aluminate (C3A) in the presence and absence of gypsum-studied by Raman spectroscopy and X-ray diffraction. Journal of Materials Chemistry. $16,1263-1272$.

Brooker M.H., Hancock G., Rice B.C., Shapter J., 1989. Raman frequency and intensity studies of liquid $\mathrm{H}_{2} \mathrm{O}, \mathrm{H}_{2}{ }^{18} \mathrm{O}$ and $\mathrm{D}_{2} \mathrm{O}$. Journal of Raman Spectroscopy. 20, 683-694.

Caine J.S., Evans J.P., Forster C.B., 1996. Fault zone architecture and permeability structure. Geology. 24, 1025-1028.

Carpenter B.M., Mollo S., Viti C., Collettini C., 2015. Influence of calcite decarbonation on the frictional behavior of carbonate-bearing gouge: implications for the instability of volcanic flanks and fault slip. Tectonophysics. 658, 128-136.

Chen J., Niemeijer A., Yao L., Ma S., 2017. Water vaporization promotes coseismic fluid pressurization and buffers temperature rise. Geophysical Research Letters. 44, 2177-2185. 
Chen J., Spiers C.J., 2016. Rate and state frictional and healing behavior of carbonate fault gouge explained using microphysical model. Journal of Geophysical Research: Solid Earth. 121, 8642-8665.

Cox J.D., Wagman D.D., Medvedev V.A., 1989. CODATA Key Values for Thermodynamics. New York: Hemisphere Publishing Corporation.

De Bresser J., and Spiers C.J., 1997. Strength characteristics of the r, f, and c slip systems in calcite. Tectonophysics. 272, 1-23.

De Paola N., Holdsworth R.E., Viti C., Collettini C., Bullock R., 2015. Can grain size sensitive flow lubricate faults during the initial stages of earthquake propagation? Earth and Planetary Science Letters. 431, 48-58.

Delle Piane C., Piazolo S., Timms N.E., Luzin V., Saunders M., Bourdet J., Giwelli A., Ben Clennell M., Kong C., Rickard W.D., 2017. Generation of amorphous carbon and crystallographic texture during low-temperature subseismic slip in calcite fault gouge. Geology. 46, 163-166.

Demurtas M., Smith S.A., Prior D.J., Spagnuolo E., Di Toro G., 2019. Development of crystallographic preferred orientation during cataclasis in low-temperature carbonate fault gouge. Journal of Structural Geology. 126, 37-50.

Di Felice R., 1995. Hydrodynamics of liquid fluidisation. Chemical engineering science. 50, 1213-1245.

Dickinson J.T., Jensen L.C., Langford S.C., Rosenberg P.E., Blanchard D.L., 1991. CO2 emission accompanying the fracture of calcite. Physics and Chemistry of Minerals. 18, 320-325.

Edvardsen C., 1999. Water Permeability and Autogenous Healing of Cracks in Concrete. In: Anonymous Innovation in Concrete Structures: Design and Construction. Thomas Telford Publishing, 473-487.

Ellis A.J., 1959. The solubility of calcite in carbon dioxide solutions. American Journal of Science. 257, 354-365.

Emmermann R., and Lauterjung J., 1997. The German continental deep drilling program KTB: overview and major results. Journal of Geophysical Research: Solid Earth. 102, 18179-18201.

Farver J.R., 1994. Oxygen self-diffusion in calcite: dependence on temperature and water fugacity. Earth and Planetary Science Letters. 121, 575-587.

Geisler T., Perdikouri C., Kasioptas A., Dietzel M., 2012. Real-time monitoring of the overall exchange of oxygen isotopes between aqueous $\mathrm{CO}_{3}{ }^{2-}$ and $\mathrm{H}_{2} \mathrm{O}$ by Raman spectroscopy. Geochimica et Cosmochimica Acta. 90, 1-11. 
Guerin S., Tofail S.A., Thompson D., 2018. Longitudinal piezoelectricity in natural calcite materials: Preliminary studies. IEEE Transactions on Dielectrics and Electrical Insulation. 25, 803-807.

Han R., Shimamoto T., Hirose T., Ree J., Ando J., 2007a. Ultralow friction of carbonate faults caused by thermal decomposition. Science. 316, 878-881.

Han R., Shimamoto T., Ando J., Ree J., 2007b. Seismic slip record in carbonatebearing fault zones: An insight from high-velocity friction experiments on siderite gouge. Geology. 35, 1131-1134.

Hauch A., Ebbesen S.D., Jensen S.H., Mogensen M., 2008. Highly efficient hightemperature electrolysis. Journal of Materials Chemistry. 18, 2331-2340.

Hielscher R., Schaeben H., 2008. A novel pole figure inversion method: specification of the MTEX algorithm. Journal of Applied Crystallography. 41, 1024-1037.

Hong K., Xu H., Konishi H., Li X., 2010. Direct-water-splitting through vibrating piezoelectric microfibers in water. The Journal of Physical Chemistry Letters. 1, 997-1002.

Hu W., Huang R., McSaveney M., Yao L., Xu Q., Feng M., Zhang X., 2019. Superheated steam, hot $\mathrm{CO}_{2}$ and dynamic recrystallization from frictional heat jointly lubricated a giant landslide: Field and experimental evidence. Earth and Planetary Science Letters. 510, 85-93.

Jiang Q., Zhang S.H., Li J.C., 2004. Grain size-dependent diffusion activation energy in nanomaterials. Solid State Communications. 130, 581-584.

Kestin J., Sokolov M., Wakeham W.A., 1978. Viscosity of liquid water in the range $8{ }^{\circ} \mathrm{C}$ to $150{ }^{\circ} \mathrm{C}$. Journal of Physical and Chemical Reference Data. 7, 941-948.

Kim S., Ree J., Han R., Kim N., Jung H., 2018. Fabric transition with dislocation creep of a carbonate fault zone in the brittle regime. Tectonophysics. 723, 107-116.

Kudłacz K., Rodriguez-Navarro C., 2014. The mechanism of vapor phase hydration of calcium oxide: implications for $\mathrm{CO}_{2}$ capture. Environmental science \& technology. 48, 12411-12418.

Lebron I., Robinson D.A., Goldberg S., Lesch S.M., 2004. The dielectric permittivity of calcite and arid zone soils with carbonate minerals. Soil Science Society of America Journal. 68, 1549-1559.

Leeman J.R., Scuderi M.M., Marone C., Saffer D.M., Shinbrot T., 2014. On the origin and evolution of electrical signals during frictional stick-slip in sheared granular material. Journal of Geophysical Research: Solid Earth. 119, 4253-4268. Lide D.R., 2004. CRC Handbook of Chemistry and Physics. Vol. 85. CRC press. 
Ma S., Shimamoto T., Yao L., Togo T., Kitajima H., 2014. A rotary-shear low to highvelocity friction apparatus in Beijing to study rock friction at plate to seismic slip rates. Earthquake science. 27, 469-497.

Manzano H., Pellenq R.J., Ulm F., Buehler M.J., van Duin A.C., 2012. Hydration of calcium oxide surface predicted by reactive force field molecular dynamics. Langmuir. 28, 4187-4197.

Martinelli G., Plescia P., 2004. Mechanochemical dissociation of calcium carbonate: laboratory data and relation to natural emissions of $\mathrm{CO}_{2}$. Physics of the Earth and Planetary Interiors. 142, 205-214.

Menzies I.A., Strafford K.N., 1975. Studies of the oxidation of titanium in carbon dioxide-I. Characteristics within the reaction temperature range $675-800^{\circ} \mathrm{C}$. Corrosion Science. 15, 69-90.

Mills G.A., Urey H.C., 1940. The kinetics of isotopic exchange between carbon dioxide, bicarbonate ion, carbonate ion and water1. Journal of the American Chemical Society. 62, 1019-1026.

Mizoguchi K., Hirose T., Shimamoto T., Fukuyama E., 2007. Reconstruction of seismic faulting by high-velocity friction experiments: An example of the 1995 Kobe earthquake. Geophysical Research Letters. 34.1.

Muto J., Nagahama H., Miura T., Arakawa I., 2008. Frictional discharge plasma and seismo-electromagnetic phenomena. Physics of the Earth and Planetary Interiors. 168, 1-5.

Oohashi K., Han R., Hirose T., Shimamoto T., Omura K., Matsuda T., 2014. Carbonforming reactions under a reducing atmosphere during seismic fault slip. Geology. 42, 787-790.

Oohashi K., Hirose T., Shimamoto T., 2011. Shear-induced graphitization of carbonaceous materials during seismic fault motion: Experiments and possible implications for fault mechanics. Journal of Structural Geology. 33, 1122-1134.

Pan S., Zhang Z., 2019. Fundamental theories and basic principles of triboelectric effect: A review. Friction. 7, 2-17.

Perdikouri C., Kasioptas A., Geisler T., Schmidt B.C., Putnis A., 2011. Experimental study of the aragonite to calcite transition in aqueous solution. Geochimica et Cosmochimica Acta. 75, 6211-6224.

Pesce G.L., Fletcher I.W., Grant J., Molinari M., Parker S.C., Ball R.J., 2017. Carbonation of hydrous materials at the molecular level: a time of flight- 
secondary ion mass spectrometry, raman and density functional theory study. Crystal Growth \& Design. 17, 1036-1044.

Plümper O., King H.E., Vollmer C., Ramasse Q., Jung H., Austrheim H., 2012. The legacy of crystal-plastic deformation in olivine: high-diffusivity pathways during serpentinization. Contributions to Mineralogy and Petrology. 163, 701724.

Polerecky L., Adam B., Milucka J., Musat N., Vagner T., Kuypers M.M., 2012. Look@ NanoSIMS-a tool for the analysis of nanoSIMS data in environmental microbiology. Environmental microbiology. 14, 1009-1023.

Pozzi G., De Paola N., Holdsworth R.E., Bowen L., Nielsen S.B., Dempsey E.D., 2019. Coseismic ultramylonites: An investigation of nanoscale viscous flow and fault weakening during seismic slip. Earth and Planetary Science Letters. 516, 164175.

Rice J.R., 2006. Heating and weakening of faults during earthquake slip. Journal of Geophysical Research: Solid Earth. 111.

Rodriguez-Navarro C., Ruiz-Agudo E., Luque A., Rodriguez-Navarro A.B., OrtegaHuertas M., 2009. Thermal decomposition of calcite: Mechanisms of formation and textural evolution of $\mathrm{CaO}$ nanocrystals. American Mineralogist. 94, 578593.

Scholz C.H., 2019. The Mechanics of Earthquakes and Faulting. Cambridge university press.

Scholz C.H., 1998. Earthquakes and friction laws. Nature. 391, 37.

Sjöberg E.L., 1976. A fundamental equation for calcite dissolution kinetics. Geochimica et Cosmochimica Acta. 40, 441-447.

Smith S., Di Toro G., Kim S., Ree J., Nielsen S., Billi A., Spiess R., 2013. Coseismic recrystallization during shallow earthquake slip. Geology. 41, 63-66.

Spagnuolo E., Plümper O., Violay M., Cavallo A., Di Toro G., 2015. Fast-moving dislocations trigger flash weakening in carbonate-bearing faults during earthquakes. Scientific reports. 5, 16112.

Takeuchi A., Nagahama H., 2002. Interpretation of charging on fracture or frictional slip surface of rocks. Physics of the Earth and Planetary Interiors. 130, 285-291.

Verberne B.A., Spiers C.J., Niemeijer A.R., De Bresser J., De Winter D., Plümper O., 2014. Frictional properties and microstructure of calcite-rich fault gouges sheared at sub-seismic sliding velocities. Pure and Applied Geophysics. 171, 2617-2640. 
Verberne B.A., de Bresser J.H., Niemeijer A.R., Spiers C.J., de Winter D.M., Plümper O., 2013. Nanocrystalline slip zones in calcite fault gouge show intense crystallographic preferred orientation: Crystal plasticity at sub-seismic slip rates at $18-150{ }^{\circ} \mathrm{C}$. Geology. 41, 863-866.

Wiles J.A., Fialkowski M., Radowski M.R., Whitesides G.M., Grzybowski B.A., 2004. Effects of surface modification and moisture on the rates of charge transfer between metals and organic materials. The Journal of Physical Chemistry B. 108, 20296-20302.

Wirtz T., Dowsett D., Philipp P., 2016. SIMS on the Helium Ion Microscope: A Powerful Tool for High-Resolution High-Sensitivity Nano-Analytics. Helium Ion Microscopy. Springer, Cam, 297-323.

Wojdyr M., 2010. Fityk: a general-purpose peak fitting program. Journal of Applied Crystallography. 43, 1126-1128.

Xu H., Hong K., Li X., 2013. Mechanism for direct-water-splitting via piezoelectrochemical effect. United States Patent. Patent No.: US8454817B2. 
Chapter 4: Formation of a silicate fault mirror under hydrous conditions - The Dixie Valley fault 


\section{Abstract}

Analyses of fault mirror surfaces are a powerful method to investigate the micro-, and nanoscale processes directly at the principal slip surface along active fault zones. We conducted crystal-slip system analyses on the Dixie Valley fault mirror aiming to unravel the unusual crystallographic preferred orientation of the Riedel shears. Our analyses suggest the bulk material at the fault-slip surface formed by precipitation of silica material from fluids. Slip-system analysis of the finegrained quartz-top layer does not match with any known slip system for quartz and we infer a non-classical mechanism of crystallographic preferred orientation formation by oriented attachment along the $\{10 \overline{1} \overline{1}\}$ high-energy surface of quartz. A second crystallographic preferred orientation inside the quartz layer overprints the non-classical crystal orientation and likely formed by creep along the fault plane and along the Riedel shears during the interseismic period. Riedel shears and the quartz top layer directly at the slip surface exhibit the same subgrain misorientation rotation around the $<\mathrm{m}>$ axis indicating the activation of the $\{\overline{1} 2 \overline{1} 0\}[0001]$ slip system. Coincidence of the subgrain misorientation at the slip surface and inside the Riedel shears allows us to connect the Riedel shears, indicative of stable sliding, to the slip surface and infer that the crystallographic preferred orientation may also be the result of stable sliding. Precipitation of amorphous carbon and hydrothermal clay alteration from kaolinite to pyrophyllite directly on the fault plane demonstrate the influence of hydrothermal fluids $>270{ }^{\circ} \mathrm{C}$. We suggest that the combination of amorphous carbon and phyllosilicates along the slip surface may facilitate aseismic fault creep along the Dixie Valley fault giving a possible explanation of the seismic gap along the Dixie Valley fault.

\subsection{Introduction}

In Chapter 1, we discussed natural carbonate fault mirrors in detail and will now focus on a lithological and mineralogical variation, namely silicate fault mirrors. Fault mirrors are smooth fault slip surfaces, often crosscutting clastic fault rocks. This type of fault surface may provide a comprehensive insight into the physico-chemical processes that occur during fault deformation. Some well-known examples of natural silicate fault mirrors are found at the Dixie Valley fault in Nevada, U.S.A. (Power and Tullis, 1989) and the Corona Heights fault (Kirkpatrick et al., 2013) in California, U.S.A. While the Corona Heights fault is a side branch of the San Andreas fault exposed at Corona Heights Park in San Francisco, the Dixie 
Valley fault is part of a hydrothermal system in the western Basin and Range Province. In this chapter, we will focus on the Dixie Valley fault mirror.

One of the prominent regional attributes possibly impacting fault mechanics in the Dixie Valley are circulating hydrothermal fluids. Fault permeability is one of the main governing factors to enable fluid circulation and silica-enrichment along faults (Caine et al., 1996). Inside the fault damage zone the permeability is highest, enabling fluid flow through a pore network or along grain boundaries (Caine et al., 1996; Evans et al., 1997). Fault slip produces or enhances the required permeability and results in fluid migration by increased pore fluid pressure (Sibson and Scott, 1998). Upon slip, a drop in pressure can cause boiling of the hydrothermal fluids and leads to supersaturation due to a concentration increase of the solute in the fluid (Henley and Hughes, 2000) and subsequent precipitation at low stress sites (Williams and Crerar, 1985). The solubility of quartz in water is dependent on pressure, temperature, and $\mathrm{pH}$ conditions (Fournier and Potter, 1982) with higher temperatures and pressures leading to a higher solubility of quartz in water (Manning, 1994) and a higher $\mathrm{pH}$ increases the solubility of silica (Williams and Crerar, 1985). The overall solubility is low for quartz (Manning, 1994), but all the above-mentioned factors can lead to the dissolution of $\mathrm{SiO}_{2}$ in water and the possible precipitation of $\mathrm{SiO}_{2}$-rich phases can lead to partial silicification of the fault after a seismic event. Fluids that are in such a way seismically pumped into the fault core can result in a pressure drop and can cause self-healing of the fault and the pore network leading to a loss of permeability and a potential repetition of the earthquake fluid cycle (Sibson et al., 1975).

Formation of fault mirrors in different lithologies has been connected with seismic events (Power and Tullis, 1989; Siman-Tov et al., 2013; Smith et al., 2013; Fondriest et al., 2013; Spagnuolo et al., 2015). As discussed in Chapter 1, the identification of microstructural features, e.g., paleo-seismicity markers, or precursor phases, is essential for fault mechanics and the determination of past rheological properties influencing the deformation behaviour. For silicate-hosted faults, the development of silica gel is reported for natural settings (Power and Tullis, 1989; Caine et al., 2010; Kirkpatrick et al., 2013) and in experiments (Goldsby and Tullis, 2002; Di Toro et al., 2004; Hayashi and Tsutsumi, 2010; Nakamura et al., 2012) and may play an important role in dynamic weakening of silicate faults. More recently, Rowe et al. (2019) reported amorphous nanosilica and there is experimental evidence for silica gel production, amorphous nanosilica or melting (Hayward et al., 
2016) but the formation mechanisms and their influence on coseismic fault rheology are not well constrained. From Chapter 2 we are aware of the potential influence of crystal plasticity during fault movement. The previous application of detailed microstructural and slip-system analyses highlights the potential of these methods to provide additional information about processes occurring during fault slip. Deformation by crystal plasticity occurs commonly by activation of one or more slip system which emit dislocations into the crystals. Subsequent arrangement through dislocation movement into subgrain walls enables the analysis of the active slip systems by determining the misorientation between subgrains. Power and Tullis (1989) discussed in their initial work the unusual crystallographic preferred features of Riedel shears and R'-shears at Dixie Valley but concluded they did not result from crystal plasticity because of the low dislocation density inside the grains. In the following Chapter, we will continue to focus on the microstructural features of the Dixie Valley fault, and we will revisit the deformation structures to unravel the potentially unusual deformation history.

Our research highlights that an initial crystallographic preferred orientation (CPO) supposedly forms by oriented attachment of the high-energy planes of $\alpha$ quartz. The initial CPO is then overprinted during stable sliding which is expressed by the same CPO of the Riedel shears and the slip surface, suggesting that both structures form through the same mechanism. Precipitation of amorphous carbon and phyllosilicates potentially aid in friction reduction and facilitate fault creep.

\subsection{Geological setting}

The Dixie Valley fault, also referred to as the Stillwater fault (Wallace and Whitney, 1984; Power and Tullis, 1989) is part of a normal fault system situated in the seismic belt of the western Basin and Range Province, Nevada, U.S.A. The outcrop studied here is termed "The Mirrors" by Power and Tullis (1989) and is located in the northern part of the Dixie Valley fault (N 39 56'48.12", W 11756'45.05"). The Dixie Valley fault separates the Stillwater Range in the west from syn-tectonic Dixie Valley basin deposits in the east (Fig. 1). The footwall of the fault consists of Mesozoic basement rocks, overlain by Tertiary sedimentary and volcanic rocks and Jurassic granodioritic to gabbroic rocks (Caine et al., 2010). The crystalline hanging wall is not exposed but the adjacent Dixie Valley basin is filled with syntectonic Tertiary and Quaternary alluvial and lacustrine sediments (Power and 
Tullis, 1989; Caine et al., 2010). The mirror surface is exposed along strike in the fault core of the Dixie Valley fault. A high degree of silicification marks the transition from fault damage zone to fault core and Caine et al. (2010) estimates for the fault core a thickness of 1-5 m. Despite the high temperatures and arid conditions throughout the year, water collects at the surface and forms the Dixie Meadow Hot Springs south of the study location (Fig. 1).

Late Cenozoic extension of the crust is responsible for the development of the fault zones and the fault offset of $6 \mathrm{~km}$ accumulated over the past 20-25 Ma (Parry et al., 1991). With an ongoing extension rate of $1 \mathrm{~cm} / \mathrm{yr}$, the divergence is the cause of the recent seismicity (Hammond and Thatcher, 2005) and seismic activity along the fault has been ongoing since the Oligocene to early Miocene (Parry et al., 1991; Caskey et al., 1996). The studied location is situated inside a 'seismic gap', i.e., along a fault segment that does not show any recorded seismicity (Wallace and Whitney, 1984). However, in 1954, a major seismic event south of Dixie Valley produced an earthquake with $M_{s}=7.2$ with a rupture on the Fairview Peak fault, quickly followed by another event on the Dixie Valley fault with $M_{s}=6.8$ (Caskey et al., 1996).

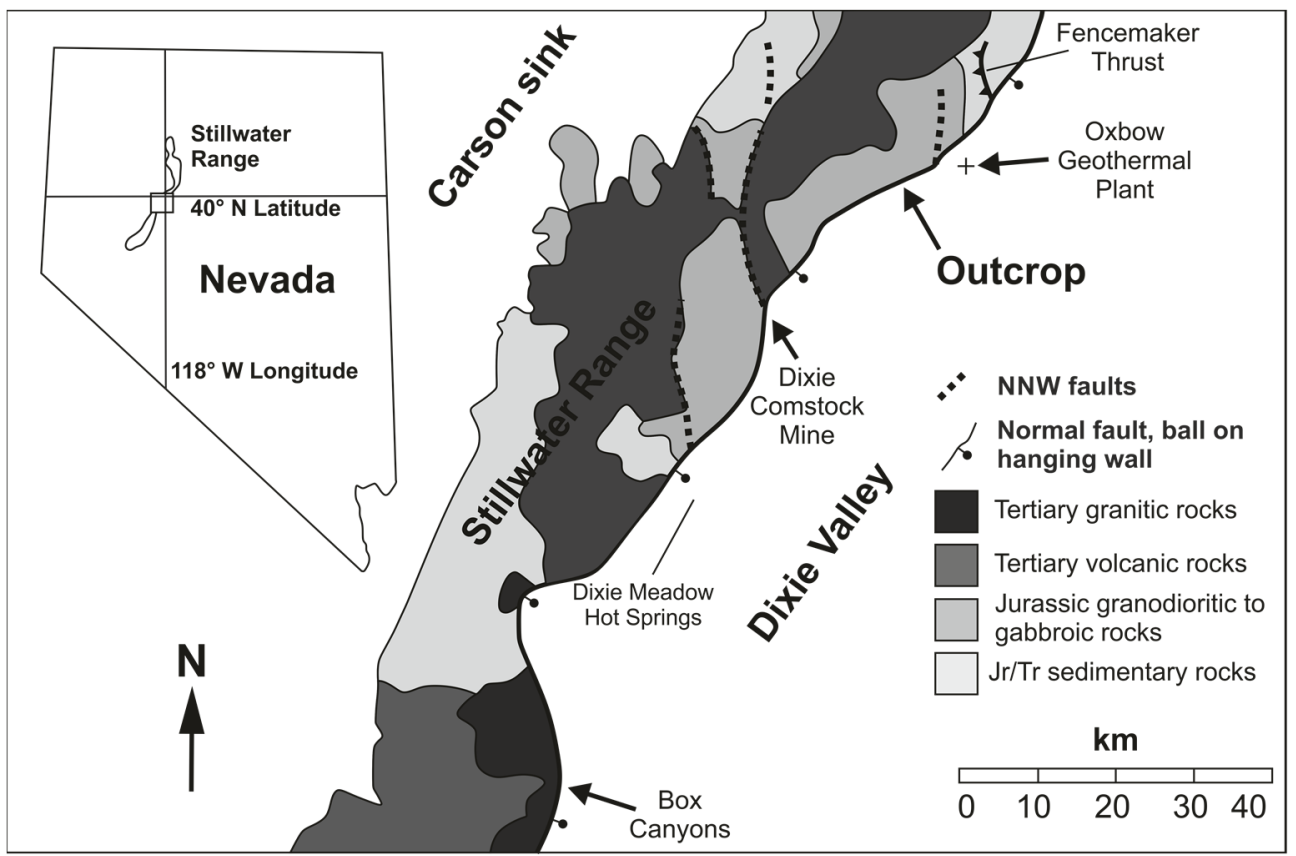

Figure 1: Geological map of study area. Modified after Lutz et al. (1997a) and Caine et al. (2010).

The typical geothermal gradient for the Basin and Range Province is 20-45 ${ }^{\circ} \mathrm{C} / \mathrm{km}$ (Lachenbruch and Sass, 1977). Measurements of the temperature in the study 
area show $285^{\circ} \mathrm{C}$ at $3 \mathrm{~km}$ depth (Blackwell et al., 2014) and water moving along the fault can cause a local geothermal gradient of 100-200 ${ }^{\circ} \mathrm{C} / \mathrm{km}$ (Parchman and Knox, 1981; Barton et al., 1997). The high geothermal gradient is the main reason for the operation of a geothermal power plant about $8 \mathrm{~km}$ north-east of the study area. The power plant produces energy from fractured, Jurassic, igneous rocks in the hanging wall of the Dixie Valley fault at a depth of $2800-3050 \mathrm{~m}$ from a $250{ }^{\circ} \mathrm{C}$ source (Barton et al., 1997; Lutz et al., 1997b; Lutz et al., 1998).

\subsection{Methods}

\subsubsection{Sample preparation}

From a total of three drill cores and two hand specimens, a total of six thin sections were prepared. The thin sections were cut parallel to the slip direction and normal to the fault surface. Thin sections were polished with $1 \mu \mathrm{m}$ and $0.3 \mu \mathrm{m}$ diamond suspensions and $0.025 \mu \mathrm{m}$ colloidal silica.

\subsubsection{Electron microscopy}

Electron-microscope analyses were carried out with a FEI Helios NanoLab G3 UC focused ion beam scanning electron microscope (FIB-SEM). For charge reduction, the samples were sputter coated with an 8-nm thick Platinum/Palladium layer. From the hand specimens, electron-transparent foils of the principal slip surface were prepared with the same instrument for nanostructural investigation. Prior to ion beam deposition of the main Platinum strip, a $200 \mathrm{~nm}$ layer of Platinum was deposited using the electron beam (2 kV, $0.4 \mathrm{nA})$ to prevent surface amorphisation. Transmission electron microscopy (TEM) was carried out with a FEI Talos F200x at an acceleration voltage of $200 \mathrm{kV}$ and $5 \mathrm{nA}$ beam current. The FEI Talos SuperEDX detector was used for chemical element mapping via energy dispersive X-rays (EDX) in scanning transmission electron microscope (STEM) mode.

\subsubsection{Crystal orientation measurements and data treatment}

For charge reduction during electron-backscatter diffraction (EBSD), the thin sections were carbon coated. Two EBSD maps were acquired. The first map in Figure 3a was acquired with a JEOL JSM $7900 \mathrm{~F}$ SEM at $15 \mathrm{kV}$ acceleration voltage, $7 \mathrm{nA}$ beam current and $0.1 \mu \mathrm{m}$ step size equipped with an Oxford Symmetry EBSD detector at JEOL Headquarters, Japan. A second map was acquired with a Philips XL30 SEM on a Nordlys 2 camera, with an accelerating voltage of $25 \mathrm{kV}$, probe 
current of $9.5 \mathrm{nA}$, and step size of $0.8 \mu \mathrm{m}$. EBSD data was digitised and treated with the Oxford Instruments HKL Technology CHANNEL5 software and the MTEX toolbox for MATLABC. The reference frame in MTEX was set to x-axis to the east, $y$-axis to the south and z-axis out of plane. The setting of the reference frame corresponds to the Oxford Instruments conversion of $\mathrm{X}\left|\mathrm{I} \mathrm{a}^{*}, \mathrm{Y}\right| \mathrm{|b}$ and $\mathrm{Z} \mid \mathrm{I}$. Grains were defined as misorientation $>10^{\circ}$ and subgrains were defined as misorientation $1 \leq 10^{\circ}$. Unindexed pixels or pixels matched as a different phase were removed and unindexed pixels were filled with the average orientation of their grain neighbours. Grains smaller than 5 pixels were excluded from the data. Pole figures were created by plotting crystal orientation data on the lower hemisphere in XY reference frame using one-point-per-grain. Misorientation inverse pole figures (MIPF) were plotted for subgrain boundaries $1-10^{\circ}$ misorientation, which is the critical misorientation angle for subgrain boundaries in quartz (White, 1977). We also plotted MIPF's of 1$2^{\circ}$ misorientation, with the purpose of the $1-2^{\circ}$ MIPF being representative of subgrain misorientation that are hardly influenced by annealing. The optimal halfwidth for pole figures was calculated with the de la Vallée-Poussin kernel approach in MTEX and range between $12-15^{\circ}$.

\subsubsection{Raman spectroscopy}

Raman spectroscopy utilized a WiTec ALPHA300 R confocal microscope to identify and characterize possible reaction products on the fault surface. We used a laser with a wavelength of $\lambda=532 \mathrm{~nm}$, a spectral grating of 600 grooves $/ \mathrm{cm}$. Spectra were acquired at 100x magnification and each measurement consists of 15 accumulations of $2 \mathrm{~s}$ integration time each. Data acquisition, data post-processing and peak fitting were performed with WiTec ProjectFour 4.1 software.

\subsection{Results}

\subsubsection{Microstructures}

Investigation of the footwall reveals a fine-grained, quartz-rich layer situated on top of a brecciated wall rock (Fig. 2a). The light-brown, aphanitic top layer varies in thickness from 5-50 mm and shows a grain-size range of 1.5-20 $\mu \mathrm{m}$ grain diameter. A discontinuous, brownish layer $<100 \mu \mathrm{m}$ thick constitutes the uppermost slip surface contact occasionally truncating larger clasts (Fig. 2b). Larger quartz and carbonate clasts, of up to $1.5-2.0 \mathrm{~mm}$ in size, are hosted inside the top layer. Quartz clasts exhibit internal, patchy areas with smaller grain size and some 
quartz clasts can host trails of fluid inclusions (Fig. 2c). EDX analyses indicate that the top layer consists mostly of quartz and hosts flow structures, mineralised with Ti-bearing phases (Fig. 2e). Those flow structures originate at the transition from the top layer to the adjacent breccia and form a wavy pattern with larger reservoirs in between. The top layer itself is separated from the wall rock breccia by a discontinuous band of idiomorphic carbonate crystals where crystal tips are truncated horizontally (Fig. 2d). The brecciated wall rock consists mainly of quartz and feldspar combined with accessory minerals of epidote, mica, and minor opaque minerals which have not been further identified.
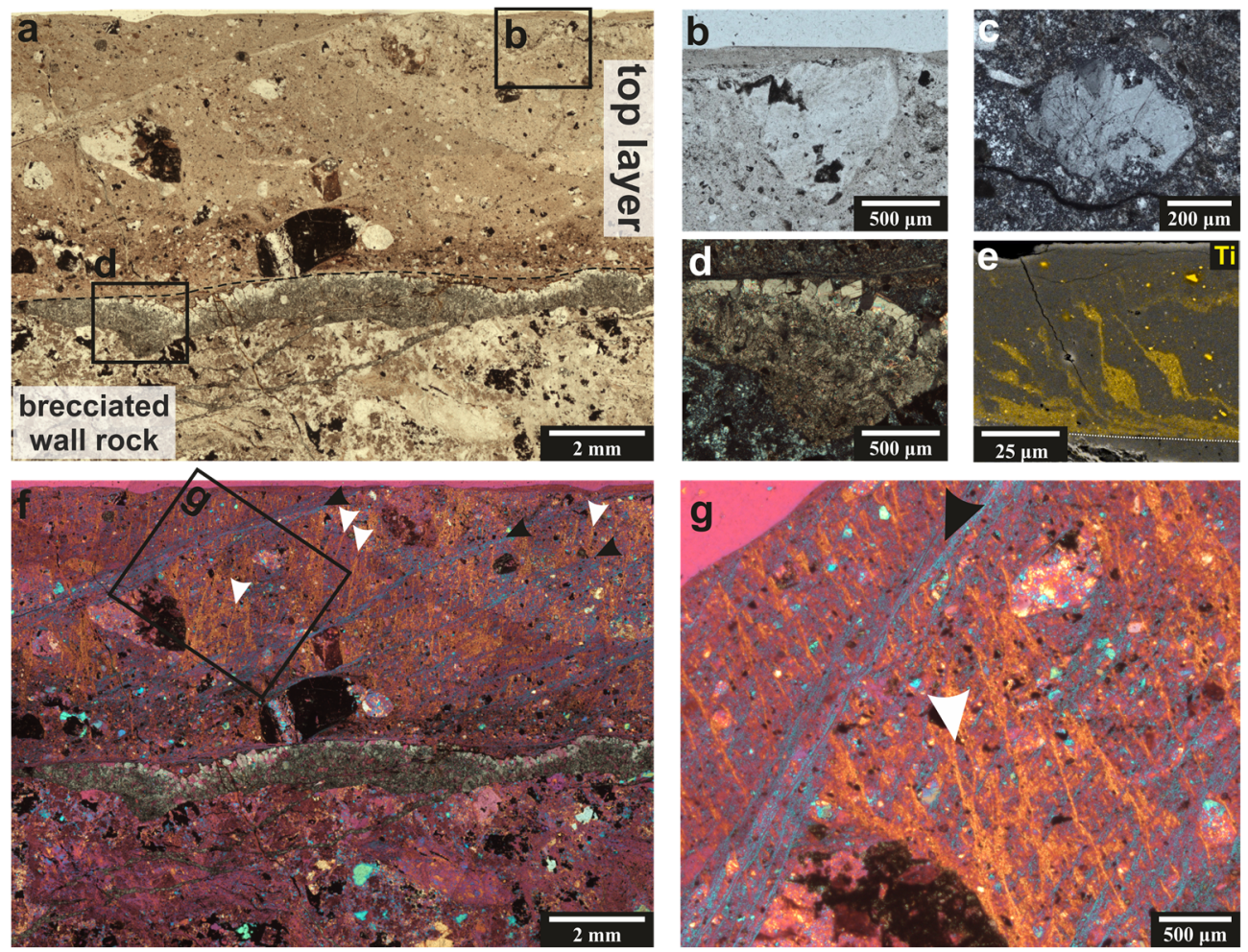

Figure 2: Overview of microstructures. a: Plane-polarised light micrograph with overview of footwall structure. The fine-grained top layer is separated from the brecciated wall rock by a discontinuous carbonate layer. $\underline{b}$ : Truncated grain at the slip surface with additional thin layer. $\underline{c}$ : Representative quartz clast with fluid inclusion trails and recrystallised areas. $\underline{\text { d: }}$ Carbonate layer with idiomorphic crystal growth with crystal tips truncated at the top. $\underline{\underline{e}}$ EDX-map overlay on secondary-electron image showing flow structures with Ti-impregnation. $f:$ Cross-polarised light micrograph with gypsum plate inserted. Two systematic sets of low angle Riedel shears (black arrows) which truncate steep dipping $R^{\prime}$-shears (white arrows). g: Detailed view from $f$ : showing the cutting relationship between $R$-shears and $R^{\prime}$-shears.

Figure $2 \mathrm{f}$ shows an overview image of the top layer CPO with gypsum plate inserted. The top layer exhibits an internal substructure showing two systematic 
quartz-axes orientations. The observations of two quartz orientations agree with the results by Power and Tullis (1989). Depending on the quartz axes orientations, the gypsum plate produces blue colours (addition, gypsum plate | | c-axis) or orange colours (subtraction, gypsum plate I | a-axes). Figure $2 \mathrm{f}$ reveals that several bands of quartz orientations dip at a shallow angle from the slip surface into the fine-grained material. Some bands exhibit a microstructural offset (e.g., Fig 2a) of a few hundred micrometres. In between the shallow dipping quartz orientations, a second, smaller set of steeply dipping orientations is located (Fig. $2 \mathrm{f}$ and $\mathrm{g}$ ). The steeply dipping quartz orientations are cut off by the shallow dipping bands (e.g., Fig. 2 g, top left). This particular geometry of quartz axes in bands form conjugate Riedel shear patterns with the shallow dipping bands being $\mathrm{R}_{1}$ or simply Riedel shears and the steep dipping bands being $\mathrm{R}_{2}$ or R'-shears (Logan, 1979; Power and Tullis, 1989). Because of the similarities to the previous work by Power and Tullis (1989) we will refer from here on to the quartz orientations as Riedel shears and R'-shears.

\subsubsection{Crystal orientation mapping}

Now that we have an overview of the Dixie Valley footwall microstructures, we will further investigate the CPO close to the slip surface and inside the Riedel shears. Adjacent to the principal slip surface (Fig. 3a), the MIPF shows a maximum of subgrain misorientation rotations close to $<\mathrm{m}>$ (Fig. $3 \mathrm{~b}$ ). There is no variation in rotation-axis orientation for misorientations of $1-2^{\circ}$ and $1-10^{\circ}$ (Fig. 3b). For the main CPO directly at the slip surface, the quartz [0001] axes are aligned subparallel to the slip surface and the $\{\overline{1} 2 \overline{1} 0\}$ planes, as well as the $\{10 \overline{1} 0\}$ planes, show a subperpendicular orientation to the slip surface (Fig. 3c). The grain size close to the slip surface range from $2.7-84 \mu \mathrm{m}$ with a median of $5 \mu \mathrm{m}$ (Fig. 3e). Figure 3 h shows the representative crystal orientation map of a Riedel shear and surrounding finegrained matrix as identified previously using a gypsum plate (Fig. 2f). The [0001] axes inside the Riedel shear have a subhorizontal orientation akin to the CPO at the slip surface. The MIPF for $1-2^{\circ}$ of the band displays a rotation around $<\mathrm{m}>$ axis whilst the MIPF for $1-10^{\circ}$ shows a rotation axis close to $\left\langle\pi^{\prime}\right\rangle$ (Fig. 3f). For the matrix hosting the Riedel shears, [0001] axes in the matrix are oriented with an antithetic inclination against the slip direction (Fig. 3i). In contrast to the Riedel shear subgrain misorientation, the MIPF of the matrix exhibits a rotation cluster around $\left\langle\pi^{\prime}>\right.$ for $1-$ $2^{\circ}$ and $1-10^{\circ}$. 


\subsubsection{Slip-surface structures}

In the following, we will investigate the structures located on top of the slip surface. Figure 4a shows an oblique top view of the Dixie Valley fault mirror. Overall, the surface appears to be smooth, and no individual grains are visible. Parallel to the slip direction, residual material forms surface striations but this material can also occur as larger patches (Fig. $4 a, b$ and c) on the slip surface. Such patches exhibit additional grains on top (Fig. 4c) or inside the patches (Fig. $4 \mathrm{~d}$ and e). The material of the patches forms a crack-like structure at the contact to the slip surface (Fig. 4b) or can leave small dents on the surface (Fig. 4c). Backscatteredelectron (BSE) imaging of the patches shows a composition of low atomic nucleus elements (low-Z) and the composition of the patches will be further investigated in the following section. In addition, BSE imaging and EDX measurements show that some patches contain euhedral $\mathrm{KCl}$ crystals (Fig. 4e). 


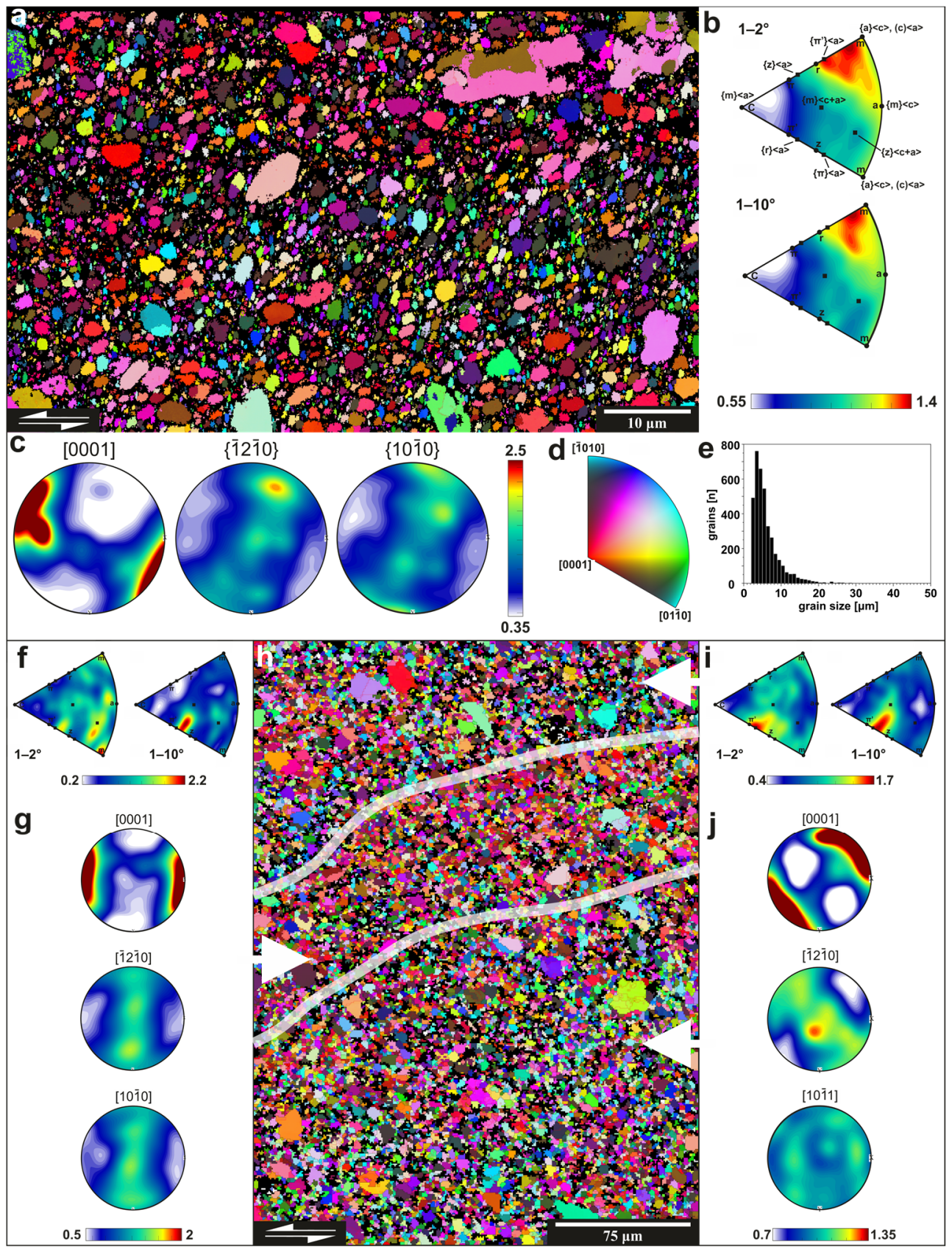

Figure 3: EBSD measurements of the Dixie Valley microstructure. a: Crystal orientation map of quartz with inverse pole figure parallel $x$ (IPF-X) colouring directly below the slip surface. $\underline{b}$ : MIPF's of $1-2^{\circ}$ and $1-10^{\circ}$ for the map

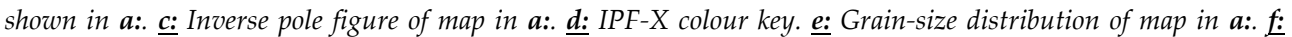
MIPF's for $1-2^{\circ}$ and $1-10^{\circ}$ of Riedel shear in $\boldsymbol{h}$ :. g: Inverse pole figures of Riedel shear in $\boldsymbol{h}:$ : $\mathbf{h}$ : Crystal orientation map of fine-grained top layer with Riedel shear in between white lines. $\underline{i}$ : MIPF's for $1-2^{\circ}$ and $1-10^{\circ}$ of matrix in h: j: Inverse pole figures of matrix. 

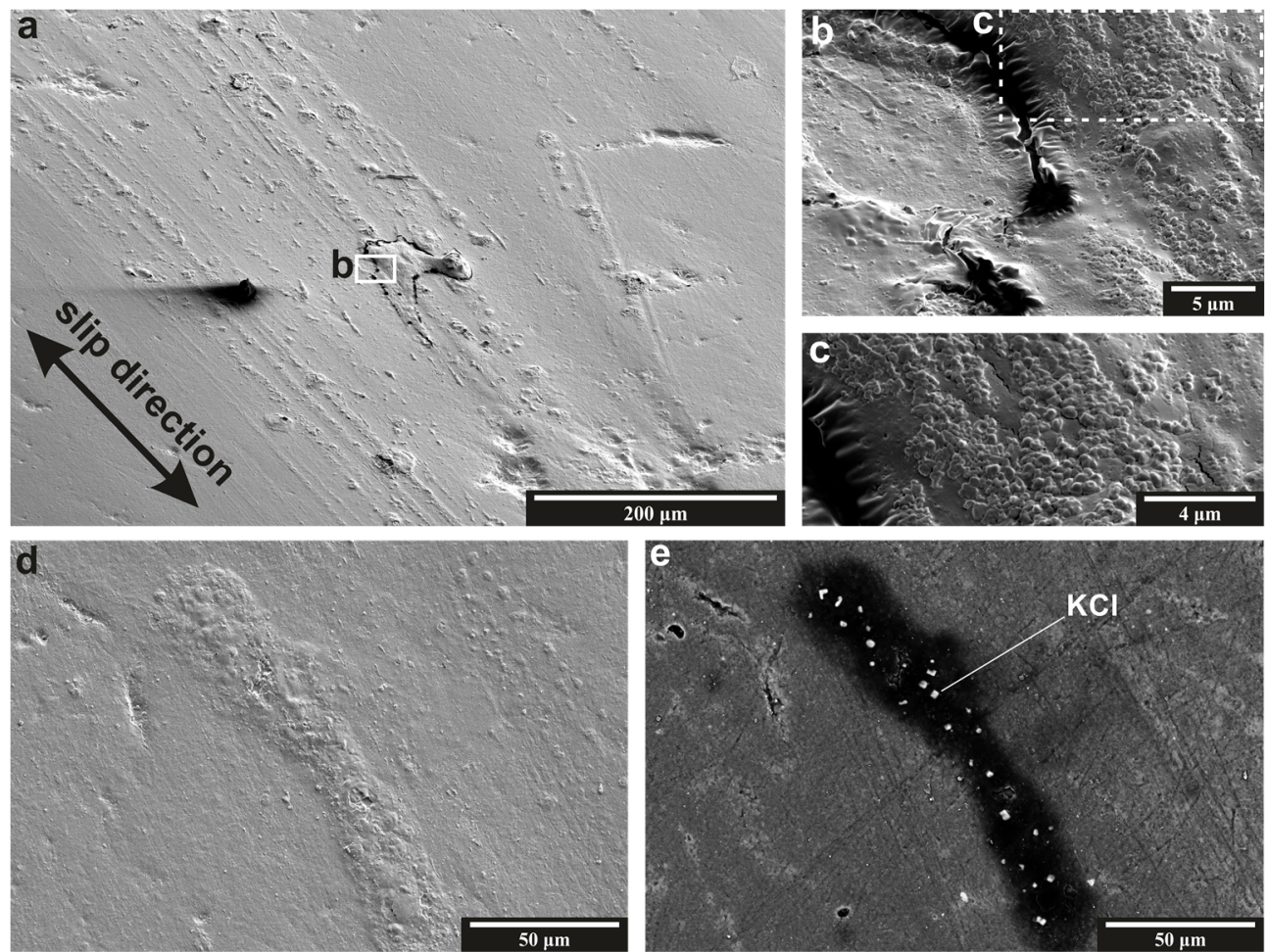

Figure 4: Representative slip surface microstructures. a: Secondary-electron image with overview of Dixie Valley slip surface. $\underline{\boldsymbol{b}}$ : Detailed view from a: with additional material as patch with drying structure on the slip surface. $\underline{\mathrm{c}}$ : Detailed view of b: Substructure on top of patch. $\underline{d}$ : Secondary-electron image of patchy structure on slip surface. e: Backscattered-electron image of patch from d:.

\subsubsection{Phase identification}

We further conduct Raman spectroscopy to characterise phases on top of the slip surface and inside the fine-grained top layer. Figure 5a shows the spectrum 1) of a quartz grain inside the top layer with the highest band intensities at $128 \mathrm{~cm}^{-1}$, $206 \mathrm{~cm}^{-1}$ and $465 \mathrm{~cm}^{-1}$, where $465 \mathrm{~cm}^{-1}$ is the main band position and corresponds to the $v_{s}$ Si-O-Si stretching-bending mode of $\alpha$ quartz (Kingma and Hemley, 1994). In addition, the spectrum shows two band positions at $2923 \mathrm{~cm}^{-1}$ and $3070 \mathrm{~cm}^{-1}$, where the band positions at $3070 \mathrm{~cm}^{-1}$ could originate from trapped water inside quartz (Gaweł et al., 2020). Spectrum 2 shows a measurement inside the fine-grained matrix close to the slip surface exhibiting the same band position at $465 \mathrm{~cm}^{-1}$ of $\alpha$-quartz. Spectra 3 and 4 were acquired on top of the slip surface, see e.g., Figure 4a. Spectrum 3 displays a band position at $465 \mathrm{~cm}^{-1}$ and additional two broad bands at $1337 \mathrm{~cm}^{-1}$ and $1574 \mathrm{~cm}^{-1}$ (D and $\mathrm{G}$ band) which are commonly associated with a disordered carbon phase. However, spectrum 4 lacks a band position at $465 \mathrm{~cm}^{-1}$ and the broad 
$\mathrm{D}$ and $\mathrm{G}$ bands at $1337 \mathrm{~cm}^{-1}$ and $1574 \mathrm{~cm}^{-1}$. For the $\mathrm{D}$ and $\mathrm{G}$ band, spectrum 3 and 4 exhibit different intensity ratios of $\frac{I(D)}{I(G)}=0.84$ for spectrum 3 and $\frac{I(D)}{I(G)}=0.78$ for spectrum 4. In addition, we also observe the disordered carbon phase inside the Riedel shears. Spectrum 4 also contains a broad band at $605 \mathrm{~cm}^{-1}$ which was mentioned by (Biswas et al., 2018) to be part of the characteristic spectrum of amorphous silica. However, the $605 \mathrm{~cm}^{-1}$ band is the only part of an amorphous silica spectrum, missing other important band positions, e.g., at $492 \mathrm{~cm}^{-1}$. At low band positions $<450 \mathrm{~cm}^{-1}$, Spectrum 4 exhibits a broad region where other positions of the quartz spectrum are absent. Opal has several band positions in this region with the most prominent at $417 \mathrm{~cm}^{-1}$, but the regular spectrum of opal lacks a band position at $605 \mathrm{~cm}^{-1}$ (Ilieva et al., 2007).

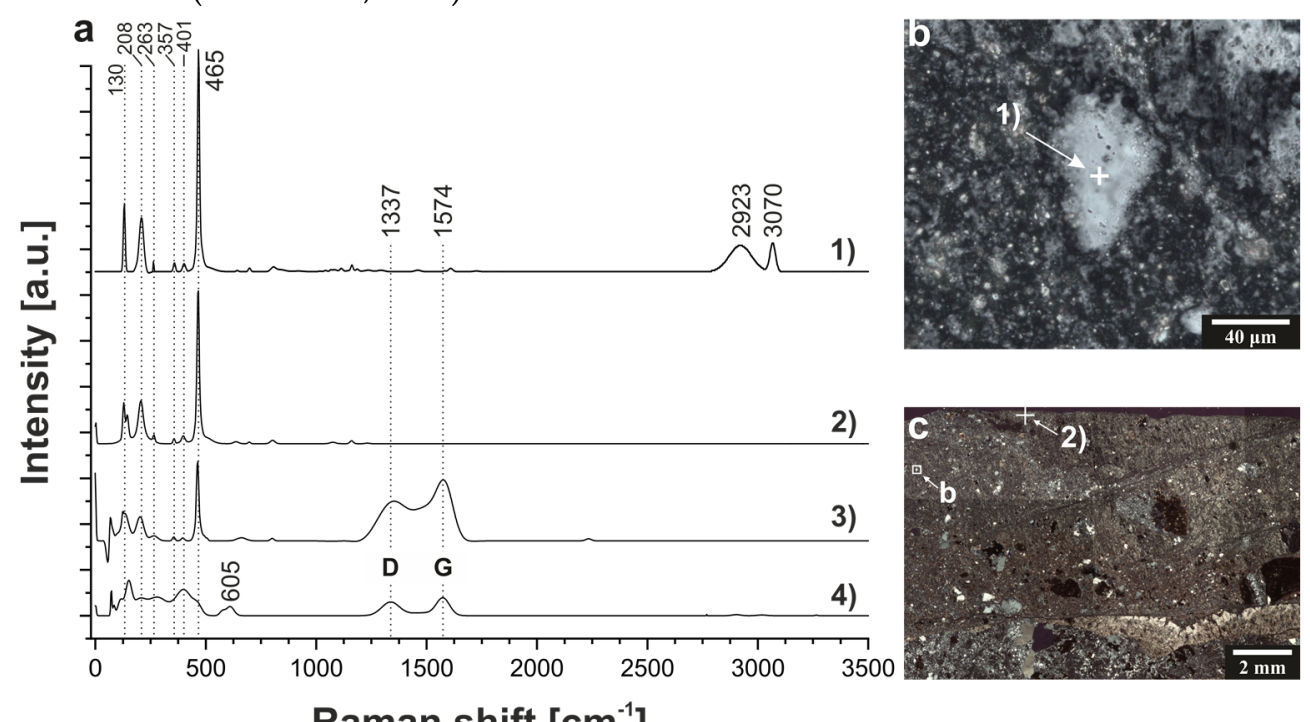

\section{Raman shift $\left[\mathrm{cm}^{-1}\right]$}

Figure 5: Raman spectroscopy results. a: Overview of relevant spectra. 1) quartz grain shown in b: 2) Fine-grained quartz matrix close to slip surface. Spectra $\underline{3}$ ) and $\underline{4}$ ) show measurement on top of the slip surface. $\underline{\text { b: }}$ Quartz grain corresponding to spectrum $\underline{\mathbf{1}}$. $\underline{\text { c: }}$ Overview indicating the location of quartz grain in b: and spectrum $\underline{\mathbf{2}}$.

\subsubsection{Nanostructures}

Because of the fine-grained nature of the top layer, we further explore the structures directly at the slip interface. Figure 6 gives an overview of the first $5 \mu \mathrm{m}$ below the slip surface and phases covering the slip surface. Figures $6 \mathrm{a}$ and $6 \mathrm{~b}$ show that the volume immediately below the slip surface mostly consists of quartz grains varying in size from 50-500 $\mathrm{nm}$. Some quartz grain boundaries meet in triple junctions, and most grains exhibit a low diffraction contrast, indicative for a low dislocation density (Fig. 6a and b). Small, platy minerals are located along grain 
boundaries or concentrated in pores (Fig. 6a and b). Larger quartz grains can host twins (Fig. 6a). Selected area electron diffraction (SAED) of the nanostructure shows the formation of discrete diffraction point clusters (Fig. 6b, inset). Figure 6c displays a cross section with the material from the patches described in section 4.3 on top of the slip surface. A diffuse SAED indicates that the material is amorphous. Moreover, clay minerals occasionally cover the surface of the fault (Fig. 6d). The lattice spacing is $\sim 0.9 \mathrm{~nm}$ indicating that it may be of pyrophyllite-type nature (Bhowmick et al., 2012).
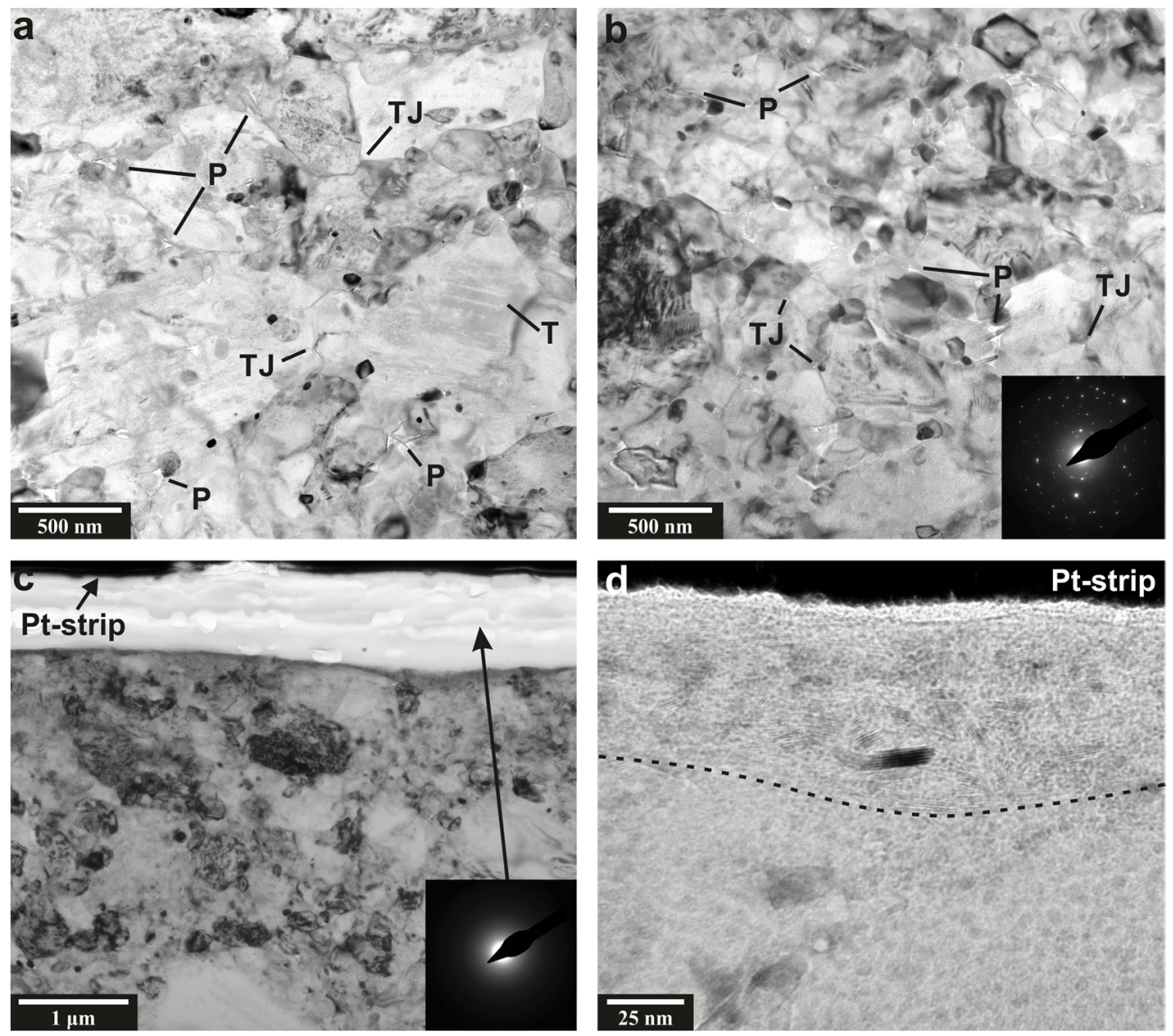

Figure 6: Representative nanostructures of the Dixie Valley fault. $\underline{a}$ : and b: Bright-field TEM image of

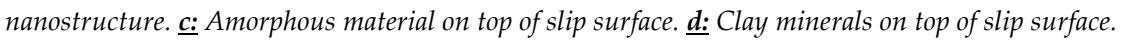

\subsection{Discussion}

\subsubsection{Crystal plasticity during fault creep}

Based on the EBSD data, crystal plasticity influenced the microstructure to a certain degree, and we will now evaluate the different spatial distributions of the 
CPOs. Adjacent to the slip surface, subgrain misorientation rotation clusters around $<\mathrm{m}>$ (Fig. 3b) correspond to tilt boundaries of the $\{\overline{1} 2 \overline{1} 0\}[0001]$ glide system in quartz (Neumann, 2000). In the following, we will refer to the $\{\overline{1} 2 \overline{1} 0\}[0001]$ glide system as $\{a\}[c]$ slip. MIPF's of $1-2^{\circ}$ and $1-10^{\circ}$ subgrain misorientation show only a minor mismatch with the $1-2^{\circ}$ plot including an additional rotation-axis cluster close to $<\mathrm{r}>$, indicating the activity of $\{01 \overline{1} 2\}<\overline{1} 2 \overline{1} 0>\left(\left\{\pi^{\prime}\right\}<\mathrm{a}>\right)$ (Fig. 3b). Because the $\{\overline{1} 2 \overline{1} 0\}$ planes are oriented subparallel to the slip surface, the $<\overline{1} 2 \overline{1} 0>$ axes show no favourable orientation for slip in $<\overline{1} 2 \overline{1} 0>$ direction dismissing the activation of $\{01 \overline{1} 2\}<\overline{1} 2 \overline{1} 0>$. However, the subparallel orientation of the $\{\overline{1} 2 \overline{1} 0\}$ planes and [0001] axis to the slip surface supports the argument that the $\{\overline{1} 2 \overline{1} 0\}[0001]$ glide system was activated directly at the slip surface. The MIPFs of the Riedel shears exhibit different rotation-axis clusters for $1-2^{\circ}$ compared to $1-10^{\circ}$ misorientation (Fig. 3f). For the 1$2^{\circ}$ misorientation, the strongest rotation axis indicates subgrain rotations around $<\mathrm{m}>$ corresponding to tilt boundaries of the $\{\overline{1} 2 \overline{1} 0\}[0001]$ glide system. This subgrain rotation is similar to the subgrain rotation directly at the slip surface. In addition, three other axes clusters $\{\mathrm{m}\}<\mathrm{c}>,\{\mathrm{z}\}<\mathrm{c}+\mathrm{a}>$ and $\{\mathrm{r}\}<\mathrm{a}>$ indicate the subordinate activity of several dislocation slip systems. However, we can rule out $\{\mathrm{z}\}<\mathrm{c}+\mathrm{a}>$ and $\{\mathrm{r}\}<\mathrm{a}>$ because the $<\overline{1} 2 \overline{1} 0>$ axes are not favourably oriented. For the $\{z\}<c+a>$ and $\{r\}<a>$ slip systems to be active, the $<a>$ axes should be oriented subparallel to the slip direction. The $<\mathrm{m}>$ axes are favourably oriented and, in combination with the MIPF data, suggest a combined activity of $\{a\}[c]$ and $\{m\}<c>$. Subgrain misorientation of $1-10^{\circ}$ indicates the activity of the $\{10 \overline{1} 1\}<\overline{1} 2 \overline{1} 0>$ slip system $(\{\mathrm{r}\}<\mathrm{a}>)$ but this is not supported by the orientation of the slip system components. Power and Tullis (1989) considered crystal plasticity to not be an active deformation mechanism because their TEM analyses showed grains with a low dislocation density. Our nanostructural observations also show grains close to the slip surface with low dislocation density (Fig. 6a and b) but considering the higher temperatures of the Dixie Valley fault, annealing of the nanostructure is to be expected. The observation of triple junctions (Fig. 6a and b) close to the slip surface is a good indication that the nanostructure was altered after its formation with previously free dislocations recovered into subgrain walls.

The $\{a\}[c]$ glide system is considered a high-temperature slip system typically only active in the temperature range $>630{ }^{\circ} \mathrm{C} \pm 30{ }^{\circ} \mathrm{C}$ in a regional metamorphic setting (Stipp et al., 2002). The $\{a\}[c]$ glide system, also referred to as secondary prism [c] slip (our case), has been reported for amphibolite-facies 
temperatures by Schmid et al. (1981) in quartzites from Galicia, Spain. For the activity of the Dixie Valley fault, Power and Tullis (1989) estimate a depth of $2 \mathrm{~km}$. Considering the high local geothermal gradient of $200^{\circ} \mathrm{C} / \mathrm{km}$ (Barton et al., 1997) and the direct temperature measurements of $285^{\circ} \mathrm{C}$ at $3 \mathrm{~km}$ depth (Blackwell et al., 2014), the temperature of $630^{\circ} \mathrm{C} \pm 30^{\circ} \mathrm{C}$ required for the activation of the $\{a\}[c]$ glide system cannot be achieved at ambient conditions. A possible explanation is a temperature increase by frictional heating (Rice, 2006) which can result in temperatures high enough to potentially melt rocks under the condition that the fault system is not fluid-buffered (Chen et al., 2017). With the presence of surface water in the form of the Dixie Meadow Hot Springs even under arid conditions (Fig. 1), we suspect that these water reservoirs are supplied with fluids from depth and that the Dixie Valley fault zone is fluid saturated. Based on this assumption, we need to further consider how a slip system that commonly operates at high temperatures may be active at lower temperatures. The study by Blacic (1975) indicates that additional implementation of water inside quartz can stimulate slip in [0001] direction. According to Blacic (1975), preferred slip in the [0001] direction can result from a higher hydroxyl-group diffusivity along the [0001]. The potential influence of hydroxyl groups on slips systems is important to consider because we measure quartz Raman spectra indicating that water is included in the crystal. Stünitz et al. (2017) propose fluid-weakening through $\mathrm{H}_{2} \mathrm{O}$-assisted dislocation generation where dislocation generation and multiplication is aided by very small fluid inclusions. In addition, Hirth and Tullis (1992) showed that the transition temperature for the activation of different slip systems in quartz decreases by up to $100{ }^{\circ} \mathrm{C}$ with the addition of water. We already discussed the possible influence of fluids on the CPO development of calcite and olivine in Chapter 2 and Chapter 3. Because fluid monitoring of the Oxbow Powerplant indicates clay minerals in the hydrothermal fluids, the euhedral clay minerals in Figure $6 \mathrm{a}$ and $6 \mathrm{~b}$ may be of hydrothermal origin and suggest that the top layer was in an exchange with hydrothermal fluids, leading to the entrapment of the clay minerals. The impact of water on crystal-plastic deformation suggests that the $\{a\}[c]$ slip system was indeed active and formed the CPO close to the slip surface and inside the Riedel shear. The observation of amorphous carbon along some Riedel shears supports the hypothesis of a link between deformation processes on the slip surface and inside the Riedel shears. In this case, slip-surface CPO and Riedel-shear CPO may be linked and could indicate 
a shared formation mechanism. However, further work is needed to test this hypothesis and assess the relative role of water on slip systems in quartz.

\subsubsection{Alternative CPO formation mechanism}

The overall CPO of the top-layer matrix (Fig. 3i and j) shows no direct evidence of crystal-plastic deformation. The MIPF's of the matrix that hosts the Riedel shears with subgrain misorientations $1-2^{\circ}$ and $1-10^{\circ}$ show no variation (Fig. 3i). Subgrain misorientation rotations would indicate the activation of the $\{r\}<a>$ slip system, but the orientation of the $\{r\}$ planes and the $<a>$ axes show no favourable alignment to indicate that this slip system was active. According to Neumann (2000) the rotation axis for tilt boundaries of the $\{r\}<a>$ slip system is roughly oriented perpendicular to the $\left\{\pi^{\prime}\right\}$ plane. The inverse pole figures in Figure $3 j$ indicate that $\{\overline{1} 2 \overline{1} 0\}[0001]$ are suitably oriented for $\{a\}[c]$ slip but lack the required subgrain rotation maxima for this slip system. The mismatch between subgrain misorientations and the orientation of slip planes suggests that the $\mathrm{CPO}$, at least in the fine-grained matrix, formed through other mechanisms than crystal plasticity.

In the following, we consider alternative mechanisms of CPO formation, such as dissolution-precipitation, preferred nucleation, and oriented attachment. The mechanisms of solution-precipitation and preferred nucleation can be coupled because the dissolution and transport of material require a fluid phase and precipitation of dissolved material can occur in low stress regions where nucleation can be governed by preferred growth. Preferred dissolution sites are at grain contacts, and any type of surface can then act as nucleation point to initiate crystal growth. For quartz, growth is fastest parallel to the c-axis (Kamb, 1959). Power and Tullis (1989) suggest a combination of (dis-)solution and precipitation to explain the CPOs of the Dixie Valley fault. However, precipitation and preferred nucleation commonly result in columnar growth structures which are absent inside the top layer. Overall, with the lack of columnar quartz growth, we suggest that the quartz $\mathrm{CPO}$ is not the result of precipitation and preferred growth.

Oriented attachment theory is based on the idea that a new crystal forms by attachment of two smaller crystals to reduce the overall surface energy (Li et al., 2012). The crystallographic planes with the highest free energy unify to maximise the number of shared lattice sites (Toy et al., 2015). Orientated attachment, therefore, deviates from the classical nucleation and growth model from a supersaturated solution. The hydrated free surface energy of quartz varies from $1.41 \mathrm{~J} / \mathrm{m}^{2}$ for the 
$\{10 \overline{1} \overline{1}\}$ plane, to $2.22 \mathrm{~J} / \mathrm{m}^{2}$ for the $\{10 \overline{1} \overline{1}\}$ plane (de Leeuw et al., 1999). For the hydration of an unhydrated $\alpha$-quartz surface with molecular water the $\{\mathrm{r}\}$ plane $(\{10 \overline{1} 1\})$ exhibits a hydration energy of $-186.8 \mathrm{~kJ} / \mathrm{mol}$ whilst the $\{\pi\}$ plane $(\{10 \overline{1} \overline{1}\})$ has only $51.7 \mathrm{~kJ} / \mathrm{mol}$ hydration energy. However, when oriented attachment proceeds through attaching of the $\{10 \overline{1} \overline{1}\}$ planes the rotation close to $\{10 \overline{1} 1\}$ may be the rotation needed to align each quartz crystal to fit with the $\{10 \overline{1} \overline{1}\}$ plane of another crystal properly. Because of the high surface energies, it is likely that the $\mathrm{CPO}$ of the matrix is the result of oriented attachment.

We now assume that the $\mathrm{CPO}$ of the matrix formed by oriented attachment and that the rotation close to $\left\{\pi^{\prime}\right\}$ in the MIPFs can be seen as the initial CPO. Consequently, the similar rotation axis distribution for $1-10^{\circ}$ inside the Riedel shear (Fig. 3f) could be interpreted as a remnant of the initial CPO. In such a case, slip along the Riedel shear would overprint the initial $\mathrm{CPO}$, resulting in different subgrain rotations evident from activation of the $\{\overline{1} 2 \overline{1} 0\}[0001]$ glide system. The same CPO inside the Riedel shear and at slip surface implies the same formation conditions. Moore and Byerlee (1992) suggest that the angle of Riedel shears from stable sliding is lower compared to stick-slip behaviour. Gu and Wong (1994) also mention Riedel shears associated with stable sliding. Hence, we propose the CPO in the Riedel shears and along the slip surface could be the result of stable sliding of the Dixie Valley fault during interseismic creep. On a speculative note, Moore and Byerlee (1992) also discuss that high pore-fluid pressures could lower Riedel shear angles, as observed in creeping section of the San Andreas fault. The hypothesis of interseismic, plastic creep is similar to the model proposed by Aharonov and Scholz (2019) that most of the interseismic deformation occurs by plastic deformation. However, this model is aimed at representing deeply buried fault zones but might be in part applicable because of the anomalously high geothermal gradient along the Dixie Valley fault. In contrast, $\mathrm{R}^{\prime}$-shears at a high angle to the fault surface may be the result of the recent seismic events, e.g., the one that occurred in 1954. Considering that the low-angle Riedel shears crosscut the high-angle $\mathrm{R}^{\prime}$-shears suggests that the Dixie Valley fault continues to creep along the Riedel shears overprinting the $\mathrm{R}^{\prime}$-shears after its formation (Fig. $2 \mathrm{f}$ and $2 \mathrm{~g}$ ).

\subsubsection{Fluid influence along the slip surface and its impact on fault rheology}

Microstructural observations of the first few micrometres show a crystalline slip surface. However, flow structures inside the top layer (Fig. 2e) may be evidence 
of a former viscous state, suggesting a possible origin from silica gel or precipitation from a fluid. While we do not have any indications for the formation of silica gel inside the top layer, the Raman spectrum 4 acquired on top of the slip surface shows a band position at $605 \mathrm{~cm}^{-1}$ that would be consistent with silica gel. However, comparison with Raman spectra show that other characteristic band positions, e.g., $492 \mathrm{~cm}^{-1}$ (Biswas et al., 2018) are missing. Opal, as a form of clustered silica, has the characteristic band positions at $414-417 \mathrm{~cm}^{-1}$ (Ilieva et al., 2007) not present. Because of the short survivability of silica gel (Rowe et al., 2019), it is an option that we measure an intermediate state of silica, gaining crystallinity and resulting in an incomplete spectrum so that further Raman spectroscopic investigation is needed. Given the reports that the circulating Dixie Valley fluids contain high amounts of silica (Blackwell et al., 2014), precipitation of silica is more likely to occur from a supersaturated fluid than from a syn-deformational production of silica gel. Hence, precipitation of silica from the hydrothermal fluid may still be related to slip events on the fault but would contribute to gel formation. Silica gel formation is inferred by e.g., Goldsby and Tullis (2002) and Di Toro et al. (2004) during friction experiments. Goldsby and Tullis (2002) discussed the rheological influence of silica gel during low-velocity sliding experiments and suggested a thixotropic behaviour of the material. The authors speculate that during sliding breakage of quartz bonds and reformation of silica bonds attain a dynamic balance which results in a stable sliding behaviour. Although the formation mechanism of the silica material in the Dixie Valley fault may be different to that proposed by Goldsby and Tullis (2002), the consequential sliding behaviour, where the fault reaches a dynamic balance in connection with the hydrothermal fluid may deliver an explanation for the origin of the aseismic behaviour in that region. As a result, the combination of high silica content in the hydrothermal fluid and the maintenance of a dynamic balance during and after silica precipitation may explain the 'seismic gap' along the Dixie Valley fault.

Raman spectroscopic investigation of the surface patches (e.g., Figure 6a) shows almost exclusively the presence of a disordered carbon phase with two broad bands at $1337 \mathrm{~cm}^{-1}$ and $1574 \mathrm{~cm}^{-1}$ commonly associated with amorphous carbon (Ferrari and Robertson, 2000). Carbon can be a constituent in hydrothermal fluids (Kirilova et al., 2018) and may not be part of the intrinsic fault system. Electrolytes are common constituents of hydrothermal fluids suggesting that the formation of $\mathrm{KCl}$ may be related to the circulating fluid (Parry, 1998). Mixing of amorphous 
carbon on the fault surface with halides, such as $\mathrm{KCl}$ in our case, suggests that amorphous carbon likely precipitated from the hydrothermal fluid. Kaolinite was reported by Power and Tullis (1989) and Caine et al. (2010) which reacts with quartz to pyrophyllite above $270{ }^{\circ} \mathrm{C}$ (Power and Tullis, 1989; Parry et al., 1991). The $d$ spacing of kaolinite is about $0.74 \mathrm{~nm}$ (Thompson and Cuff, 1985), while the $d$-spacing of pyrophyllite is approx. $0.9 \mathrm{~nm}$ (Bhowmick et al., 2012). Alteration of clay minerals covering the slip surface (Fig. 6d) may, therefore, indicate the presence of hightemperature, hydrothermal fluids along the fault plane. The combined precipitate of amorphous carbon and altered clay minerals may form a composite material which may exhibit low frictional strength because amorphous carbon has a friction coefficient of $\mu=0.15$ (Oohashi et al., 2011) and phyllosilicate minerals can have a friction coefficient as low as $\mu=0.2$ (Tesei et al., 2012). The combination of these two low-friction materials may reduce friction along the fault plane and facilitate interseismic creep.

\subsection{Conclusion}

We conclude that the crystallographic preferred orientations of the Dixie Valley fault likely develop by precipitation of silica material from a fluid during an interseismic period. Both, the Riedel shears, and the fined-grained quartz top-layer directly at the slip surface exhibit the same subgrain misorientation around the $<\mathrm{m}>$ axis, indicating the activation of the $\{\overline{1} 2 \overline{1} 0\}[0001]$ slip system. This similarity allows us to connect the Riedel shears, indicative of stable sliding, to the slip surface and infer that the CPO along the slip surface may also be the result of stable sliding. Because the mismatch of slip system between the slip surface and the bulk top-layer we infer non-classical CPO formation by oriented attachment along the $\{10 \overline{1} 1\}$ highenergy surface of quartz. Precipitation of amorphous carbon and hydrothermal clay alteration from kaolinite to pyrophyllite demonstrates the influence of hydrothermal fluids directly along the slip surface. The combination of amorphous carbon and phyllosilicates along the slip surface may facilitate aseismic fault creep along the

Dixie Valley fault giving a possible explanation of the seismic gap.

\section{References}

Aharonov E., Scholz C.H., 2019. The brittle-ductile transition predicted by a physicsbased friction law. Journal of Geophysical Research: Solid Earth. 124, 27212737. 
Barton C.A., Hickman S., Morin R.H., Zoback M.D., Finkbeiner T., Sass J., Benoit D., 1997. Fracture permeability and its relationship to in-situ stress in the Dixie Valley, Nevada, geothermal reservoir. USGS Staff - Published Research. 359. https://digitalcommons.unl.edu/usgsstaffpub/359

Bhowmick R., Ghosh K., Varadachari C., 2012. An ab initio Approach to Construct Clay Mineral Structures: II. Pyrophyllite. Clay Research. 31, 7-11.

Biswas R.K., Khan P., Mukherjee S., Mukhopadhyay A.K., Ghosh J., Muraleedharan K., 2018. Study of short range structure of amorphous Silica from PDF using $\mathrm{Ag}$ radiation in laboratory XRD system, RAMAN and NEXAFS. Journal of Non-Crystalline Solids. 488, 1-9.

Blacic J.D., 1975. Plastic-deformation mechanisms in quartz: the effect of water. Tectonophysics 27, 271-294.

Blackwell D., Smith R., and Richards M., 2014. Dixie Valley Synthesis. SMU Geothermal Laboratory Southern Methodist University Dallas, Texas.

Caine J.S., Bruhn R.L., Forster C.B., 2010. Internal structure, fault rocks, and inferences regarding deformation, fluid flow, and mineralization in the seismogenic Stillwater normal fault, Dixie Valley, Nevada. Journal of Structural Geology. 32, 1576-1589.

Caine J.S., Evans J.P., Forster C.B., 1996. Fault zone architecture and permeability structure. Geology. 24, 1025-1028.

Caskey S.J., Wesnousky S.G., Zhang P., Slemmons D.B., 1996. Surface faulting of the 1954 Fairview Peak (Ms 7.2) and Dixie Valley (Ms 6.8) earthquakes, central Nevada. Bulletin of the Seismological Society of America. 86, 761-787.

Chen J., Niemeijer A., Yao L., Ma S., 2017. Water vaporization promotes coseismic fluid pressurization and buffers temperature rise. Geophysical Research Letters. 44, 2177-2185.

de Leeuw N.H., Higgins F.M., Parker S.C., 1999. Modeling the surface structure and stability of $\alpha$-quartz. The Journal of Physical Chemistry B. 103, 1270-1277.

Di Toro G., Goldsby D.L., Tullis T.E., 2004. Friction falls towards zero in quartz rock as slip velocity approaches seismic rates. Nature. $427,436$.

Evans J.P., Forster C.B., Goddard J.V., 1997. Permeability of fault-related rocks, and implications for hydraulic structure of fault zones. Journal of Structural Geology. 19, 1393-1404.

Ferrari A.C., Robertson J., 2000. Interpretation of Raman spectra of disordered and amorphous carbon. Physical Review B. 61, 14095. 
Fondriest M., Smith S.A., Candela T., Nielsen S.B., Mair K., Di Toro G., 2013. Mirrorlike faults and power dissipation during earthquakes. Geology. 41, 1175-1178.

Fournier R.O., Potter II R.W., 1982. An equation correlating the solubility of quartz in water from 25 to $900{ }^{\circ} \mathrm{C}$ at pressures up to 10,000 bars. Geochimica et Cosmochimica Acta. 46, 1969-1973.

Gaweł B.A., Ulvensøen A., Łukaszuk K., Arstad B., Muggerud A.M.F., Erbe A., 2020. Structural evolution of water and hydroxyl groups during thermal, mechanical and chemical treatment of high purity natural quartz. RSC Advances. 10, 2901829030.

Goldsby D.L., Tullis T.E., 2002. Low frictional strength of quartz rocks at subseismic slip rates. Geophysical Research Letters. 29, 25-4.

Gu Y., Wong T., 1994. Development of shear localization in simulated quartz gouge: Effect of cumulative slip and gouge particle size. Pure and Applied Geophysics. $143,387-423$.

Hammond W.C., Thatcher W., 2005. Northwest Basin and Range tectonic deformation observed with the Global Positioning System, 1999-2003. Journal of Geophysical Research: Solid Earth. 110.B10.

Hayashi N., Tsutsumi A., 2010. Deformation textures and mechanical behavior of a hydrated amorphous silica formed along an experimentally produced fault in chert. Geophysical Research Letters. 37.12.

Hayward K.S., Cox S.F., Gerald J.D.F., Slagmolen B.J., Shaddock D.A., Forsyth P.W., Salmon M.L., Hawkins R.P., 2016. Mechanical amorphization, flash heating, and frictional melting: Dramatic changes to fault surfaces during the first millisecond of earthquake slip. Geology. 44, 1043-1046.

Hirth G., Tullis J., 1992. Dislocation creep regimes in quartz aggregates. Journal of Structural Geology. 14, 145-159.

Ilieva A., Mihailova B., Tsintsov Z., Petrov O., 2007. Structural state of microcrystalline opals: A Raman spectroscopic study. American Mineralogist. 92, 1325-1333.

Kamb W.B., 1959. Theory of preferred crystal orientation developed by crystallization under stress. The Journal of Geology. 67, 153-170.

Kingma K.J., Hemley R.J., 1994. Raman spectroscopic study of microcrystalline silica. American Mineralogist. 79, 269-273.

Kirilova M., Toy V.G., Timms N., Halfpenny A., Menzies C., Craw D., Beyssac O., Sutherland R., Townend J., Boulton C., 2018. Textural changes of graphitic 
carbon by tectonic and hydrothermal processes in an active plate boundary fault zone, Alpine Fault, New Zealand. Geological Society, London, Special Publications. 453, 205-223.

Kirkpatrick J.D., Rowe C.D., White J.C., Brodsky E.E., 2013. Silica gel formation during fault slip: Evidence from the rock record. Geology. 41, 1015-1018.

Lachenbruch A.H., Sass J.H., 1977. Heat flow in the United States and the thermal regime of the crust. The Earth's crust. 20, 626-675.

Li D., Nielsen M.H., Lee J.R., Frandsen C., Banfield J.F., De Yoreo J.J., 2012. Directionspecific interactions control crystal growth by oriented attachment. Science. 336, 1014-1018.

Logan J.M., 1979. Experimental Studies of Simulated Gouge and their Application to Studies of Natural Fault Zones. Proceedings of Conference VIII-Analysis of Actual Fault Zones in Bedrock, 305-343.

Lutz S.J., Moore J.N., Benoit D., 1997a. Geologic Framework of Jurassic Reservoir Rocks in the Dixie Valley Geothermal Field, Nevada: Implications from Hydrothermal Alteration and Stratigraphy. Proceedings, 22 ${ }^{\text {nd }}$ Workshop on Geothermal Reservoir Engineering. 27-29.

Lutz S.J., Moore J.N., Benoit D., 1997b. Geologic Framework of Jurassic Reservoir Rocks in the Dixie Valley Geothermal Field, Nevada: Implications from Hydrothermal Alteration and Stratigraphy. In: Anonymous Proceedings, 22nd Workshop on Geothermal Reservoir Engineering. 27-29.

Lutz S.J., Moore J.N., Benoit D., 1998. Integrated Alteration Mineralogy and Fluid inclusion Study at the Dixie Valley Geothermal Field, Nevada. Proceedings 23 ${ }^{\text {rd }}$ Workshop on Geothermal Reservoir Engineering, Stanford Univ. Report SGPTR-IS8. 315-332.

Manning C.E., 1994. The solubility of quartz in $\mathrm{H}_{2} \mathrm{O}$ in the lower crust and upper mantle. Geochimica et Cosmochimica Acta. 58, 4831-4839.

Moore D.E., Byerlee J., 1992. Relationships between sliding behavior and internal geometry of laboratory fault zones and some creeping and locked strike-slip faults of California. Tectonophysics. 211, 305-316.

Nakamura Y., Muto J., Nagahama H., Shimizu I., Miura T., Arakawa I., 2012. Amorphization of quartz by friction: Implication to silica-gel lubrication of fault surfaces. Geophysical Research Letters. 39.21. 
Neumann B., 2000. Texture development of recrystallised quartz polycrystals unravelled by orientation and misorientation characteristics. Journal of Structural Geology. 22, 1695-1711.

Oohashi K., Hirose T., Shimamoto T., 2011. Shear-induced graphitization of carbonaceous materials during seismic fault motion: Experiments and possible implications for fault mechanics. Journal of Structural Geology. 33, 1122-1134.

Parchman Jr W.L., Knox J.W., 1981. Exploration for Geothermal Resources in Dixie Valley, Nevada: Case History. AAPG Bulletin. 65, 968.

Parry W.T., 1998. Fault-fluid compositions from fluid-inclusion observations and solubilities of fracture-sealing minerals. Tectonophysics. 290, 1-26.

Parry W.T., Hedderly-Smith D., Bruhn R.L., 1991. Fluid inclusions and hydrothermal alteration on the Dixie Valley fault, Nevada. Journal of Geophysical Research: Solid Earth. 96, 19733-19748.

Power W.L., Tullis T.E., 1989. The relationship between slickenside surfaces in finegrained quartz and the seismic cycle. Journal of Structural Geology. 11, 879893.

Rice J.R., 2006. Heating and weakening of faults during earthquake slip. Journal of Geophysical Research: Solid Earth. 111.B5.

Rowe C.D., Lamothe K., Rempe M., Andrews M., Mitchell T.M., Di Toro G., White J.C., Aretusini S., 2019. Earthquake lubrication and healing explained by amorphous nanosilica. Nature communications. 10, 1-11.

Schmid S.M., Casey M., Starkey J., 1981. An illustration of the advantages of a complete texture analysis described by the orientation distribution function (ODF) using quartz pole figure data. Tectonophysics. 78, 101-117.

Sibson R.H., Moore J.M.M., Rankin A.H., 1975. Seismic pumping-a hydrothermal fluid transport mechanism. Journal of the Geological Society. 131, 653-659.

Sibson R.H., Scott J., 1998. Stress/fault controls on the containment and release of overpressured fluids: Examples from gold-quartz vein systems in Juneau, Alaska; Victoria, Australia and Otago, New Zealand. Ore Geology Reviews. 13, 293-306.

Siman-Tov S., Aharonov E., Sagy A., Emmanuel S., 2013. Nanograins form carbonate fault mirrors. Geology. 41, 703-706.

Smith S., Di Toro G., Kim S., Ree J., Nielsen S., Billi A., Spiess R., 2013. Coseismic recrystallization during shallow earthquake slip. Geology. 41, 63-66. 
Spagnuolo E., Plümper O., Violay M., Cavallo A., Di Toro G., 2015. Fast-moving dislocations trigger flash weakening in carbonate-bearing faults during earthquakes. Scientific reports. 5, 16112.

Stipp M., Stünitz H., Heilbronner R., Schmid S.M., 2002. The eastern Tonale fault zone: a 'natural laboratory' for crystal-plastic deformation of quartz over a temperature range from 250 to 700 C. Journal of Structural Geology 24, 18611884.

Stünitz, H., Thust, A., Heilbronner, R., Behrens, H., Kilian, R., Tarantola, A., Fitz Gerald, J. D., 2017. Water redistribution in experimentally deformed natural milky quartz single crystals-Implications for $\mathrm{H} 2 \mathrm{O}$-weakening processes. Journal of Geophysical Research: Solid Earth. 122, 866-894.

Tesei T., Collettini C., Carpenter B.M., Viti C., Marone C., 2012. Frictional strength and healing behavior of phyllosilicate-rich faults. Journal of Geophysical Research: Solid Earth. 117.B9.

Thompson J.G., Cuff C., 1985. Crystal structure of kaolinite: dimethylsulfoxide intercalate. Clays and Clay Minerals. 33, 490-500.

Toy V.G., Mitchell T.M., Druiventak A., Wirth R., 2015. Crystallographic preferred orientations may develop in nanocrystalline materials on fault planes due to surface energy interactions. Geochemistry, Geophysics, Geosystems. 16, 25492563.

Wallace R.E., Whitney R.A., 1984. Late Quaternary history of the Stillwater seismic gap, Nevada. Bulletin of the Seismological Society of America. 74, 301-314.

White S., 1977. Geological significance of recovery and recrystallization processes in quartz. Tectonophysics. 39, 143-170.

Williams L.A., Crerar D.A., 1985. Silica diagenesis; II, General mechanisms. Journal of Sedimentary Research. 55, 312-321. 
Chapter 5: Summary, discussion, and outlook 


\section{General Summary}

In the following paragraphs we provide the reader with a summary of each of the previous chapters. We will then discuss general points of this thesis and some additional findings that were not included in the chapters. Finally, we will give a few suggestions for future work based on the work presented in this thesis.

Chapter 1 focused on the nanoscale analysis of deformation structures on the principal slip surface and the first tens of micrometres below that of two carbonate fault mirrors from Central Greece. The chapter highlights the thermochemical changes resulting from decarbonation of calcite during fault slip along the natural fault plane. A combination of multi-scale electron microscopy and Raman spectroscopy reveals a series of reactions suggesting decarbonation products reacted with a fluid to form portlandite $\left(\mathrm{Ca}(\mathrm{OH})_{2}\right)$ and amorphous carbon $(\mathrm{a}-\mathrm{c})$. A thin coating on the principal slip surface with a-c is ultimately responsible for smoothing out surface corrugations and forming a flat surface. Further alteration of the nearfield electron bonding of a-c (hybridisation) results in $\mathrm{sp}^{2}$-ordering of the amorphous material. Syn-deformational grain-size reduction produces primary calcite nanograins $>100 \mathrm{~nm}$. Nanocrystalline-calcite grains $<50 \mathrm{~nm}$ form via back-reaction of portlandite with $\mathrm{CO}_{2}$ leading to the formation of secondary nanograins. Structurally, the secondary nanograins are located inside the a-c and suggest that the a-c functions as a reaction medium for the back-reaction of portlandite to calcite. The coverage of a-c over the entire fault plane suggests that after the onset of fault slip, further displacement along the fault plane may be facilitated by the a-c film. The identification of an a-c coating presents a strong contrast to the previous hypothesis of a nanogranular calcite coating being responsible for producing fault mirror surfaces.

In Chapter 2, we focus on the crystal-plastic deformation aspect of both Greek carbonate fault mirrors. High-resolution crystal-orientation data allows detailed slip-system analyses and reveals a vital contribution of crystal plasticity to form the existing microstructure. For the Arkitsa fault surface, we find a microstructure with triple junctions in the cataclastic region of the fault rock and, a nanostructure directly at the slip surface with the same grain-boundary structure. The micro-, and nanostructures of both faults indicate the activation of the $(0001)<\overline{1} 2 \overline{1} 0>$ slip system and in addition, the $\{10 \overline{1} 4\}<\overline{2} 021>$ slip system for the Schinos cataclasite. Comparison of activation temperatures of both slip systems 
suggest temperature $>600{ }^{\circ} \mathrm{C}$. In this chapter we propose that the introduction of plastic strain into the microstructure prompts the onset of static recrystallisation and reduction of grain size, similar to the engineering process of cold-rolling and annealing. Calculations approximating the postseismic grain-growth potential show that under the assumption that aqueous fluids are present, grain growth may alter the appearance of the microstructure on a short timescale of less than one year. However, the resulting microstructure is often considered diagnostic for grainboundary sliding mechanisms, which leaves the question open to what degree grainboundary sliding contributes to the microstructural formation. Deformation mechanism maps suggest that without constraints on the syn-deformational differential stress, an interpretation of the microstructure becomes challenging. We showed that a piezometric relationship can only be used with caution in fault gouges because in such a case, grains $<200 \mathrm{~nm}$ situated in the high-localisation deformation zone at the slip surface would imply differential stresses $>3 \mathrm{GPa}$, in disagreement with observations made from natural fault zones. The overprinting relationships are evidence for fault reactivation along the same fault plane and suggest that postseismic annealing is an effective way to decrease the grain size. Microstructural evidence indicates that a reduction in grain size leads to a grain-boundary strengthening effect and a stronger microstructure. The cyclic repetition of plastic straining and annealing leads inevitably to the relocation of the fault place because the grain size will become small, thereby increasing the strength of the slip zone, favouring the re-localization of the deformation on a new slip surface. Overall, the results from Chapter 2 suggest that crystal plasticity plays a larger role during cataclasis then previously considered and that the microstructure indicative for grain-boundary sliding may equally indicate microstructural annealing.

Chapter 3 presented laboratory fault-gouge deformation experiments under hydrous conditions. We conducted sub-seismic $\left(v=0.1 \mu \mathrm{m} / \mathrm{s}, \sigma_{n}=50 \mathrm{MPa}, T=92^{\circ}\right)$ and seismic $\left(v=1 \mathrm{~m} / \mathrm{s}, \sigma_{n}=2\right.$ and $\left.4 \mathrm{MPa}\right)$ sliding experiments with pre-ground calcite fault gouge under dry and wet conditions. We utilised $\mathrm{H}_{2}{ }^{18} \mathrm{O}$ as pore fluids to track and identify fluid-rock interactions during low-, and high-velocity carbonate deformation. A combination of Raman spectroscopy and two high-resolution secondary ion mass spectrometry techniques enabled us to locate and measure ${ }^{18} \mathrm{O}$ incorporation. The working hypothesis for this chapter was to identify whether calcite interacts with the fluid during slow and fast deformation, or to what degree. The formation of entire new calcite grains with ${ }^{18} \mathrm{O}$ showed that the material 
exchanged isotopes with the pore fluid. Co-formation of portlandite showed that decarbonation products dissolved and exchanged isotopes with $\mathrm{H}_{2}{ }^{18} \mathrm{O}$ via fluidmediated processes and not as solid-state transformation mechanisms. Fluidmediated isotope exchange must have been fast and efficient to result in sufficient ${ }^{18} \mathrm{O}$ incorporation into the calcite crystal structure on the time scale of the highvelocity experiments (20 seconds). Formation of amorphous carbon (a-c) during the experiments suggests that the $\mathrm{CO}_{2}$ is reduced by $\mathrm{H}_{2}$. We hypothesise that $\mathrm{H}_{2}$ formed by electrolysis where the required electric potential is supplied without a direct redox pair from tribo-electric charging by interparticle friction. We measured the same crystallographic preferred orientation as in natural carbonate faults but could now combine the measurements with direct constraints on deformation temperature, which are less than $600{ }^{\circ} \mathrm{C}$. The present work showed that during deformation, calcite decarbonated during both, high and low-velocity experiments, despite the temperature increase in the high-velocity experiment being fluidbuffered. A combination of low a-c friction and pressurised volatiles was suggested to be responsible for the dynamic weakening of the fault. Estimations of the total isotope exchange suggested that approx. $65 \%$ of the fault gouge did not deform as calcite in the high-velocity experiments but formed a transient phase with a mixture of calcite starting material, pressurised volatiles, and various non-crystalline phases, as the result of decarbonation and fluid-solid phase interaction. Chapter 3 demonstrated that deformation of carbonates under hydrous conditions cannot be described with fluid-enhanced solid-state deformation mechanisms of calcite but necessitate considerations of the physico-chemical changes and phase transformations as soon as aqueous fluids are present.

Chapter 4 lead us back into the field with a case study of a silicate-fault mirror. In this final chapter, we applied our crystal-slip system analyses, also employed in Chapter 2, on the Dixie Valley fault mirror. Previous studies already reported the presence of multiple crystallographic preferred orientations that were formed under conditions where conventional processes for the formation of a crystallographic preferred orientation are unlikely. We aimed with our microstructural analysis at shedding light on the formation mechanisms of these enigmatic crystal preferred orientations. At the slip surface and inside Riedel shears, quartz [0001] axes were aligned subparallel and $<\overline{1} 2 \overline{1} 0>$ axes were aligned subperpendicular to the slip direction. The subgrain misorientations around $<$ m $>$ indicated the activation of the $\{\overline{1} 2 \overline{1} 0\}[0001]$ slip system, which is usually assumed to 
indicate deformation temperatures $>600{ }^{\circ} \mathrm{C}$. The initial crystallographic preferred orientation of the matrix did not match with known quartz slip systems and as previous studies indicated, supposedly formed by non-classical mechanisms. We hypothesise that oriented attachment is a likely mechanism to form the investigated crystal orientation by combining high-energy surfaces of quartz. Because of regional use of the sub-surface for geothermal energy production, sub-surface temperatures are well constrained for the region and indicate lower values of $<300{ }^{\circ} \mathrm{C}$. Because the active slip systems at the slip surface and inside Riedel shear structures are the same, we suggest that those two crystallographic preferred orientations formed as the result of stable, interseismic creep. The geomorphology suggests a fluidsaturated fault system where we can expect the coseismic temperature increase to be fluid-buffered. On the speculative side, the complex-composite material of amorphous carbon and phyllosilicates may contribute in a minor way to stable sliding along the fault plane but needs further investigation. Stable sliding along large portions of the Dixie Valley fault may be the origin of the 'seismic gap' anomaly where no seismic events are produced. The results of Chapter 4 match the observation from Chapter 3 that fluid saturation influences crystal plasticity and slip systems seem to operate at lower temperatures when fluids are present.

Finally, we conclude that the syn-, and post-deformational fluid-rock interactions have a strong influence on fault slip and that such interactions with fluids are the governing factor that will control fault rheology in the systems studied here.

\section{General discussion and conclusions}

Based on the results of the previous chapters, we conclude that nanograin coatings are not a requirement to form mirror slip surfaces. This conclusion contrasts with previous work by e.g., Siman-Tov et al. (2013) who proposed that fault mirrors form due to a nanograin coating. As suspected in Chapter 1 and confirmed in Chapter 3, it is the interaction of decarbonation products with fluids that leads to a cascade of reactions forming mirror slip surfaces. In particular, the precipitation of amorphous carbon and its primary role in smoothing out the topmost slip surface is what governs the formation of a fault mirror surface. The second role of amorphous carbon is to contribute to dynamic weakening as shown in Chapter 3. As discussed in Chapter 3, the velocity-dependent friction coefficient of amorphous carbon $\left(\mu_{\mathrm{ss}}=\right.$ 0.56 at $v=1 \mathrm{~mm} / \mathrm{s}$ versus $\mu_{\mathrm{ss}}=0.15$ at $v=1.3 \mathrm{~m} / \mathrm{s}$ ) determined by Oohashi et al. (2011) 
suggests that amorphous carbon is not alone responsible for dynamic weakening in the performed high-velocity experiments. Hence, dynamic weakening during seismic slip in carbonate rocks is probably the result of the interaction between decarbonation products and the available pore fluid.

The evolution of the cataclastic microstructure is summarised in Figure 1. The combined results from Chapter 1 and 2 lead to a 4-stage nanostructural model, where evolution and strengthening of the micro-, and nanostructure is dictated by overprinting and static recrystallisation. The model begins after the first main episode of grain-size reduction where the microstructure gets modified by static recrystallisation. Evidence from the high-velocity experiments in Chapter 3 suggest that the conditions during and after the fluid-saturated experiments were already favouring static recrystallisation (Fig. 2). Stage 2 describes the reactivation of the equilibrium nanostructure where grains are displaced along an angled slip plane and amorphous carbon precipitates on the slip surface. Consequently, new calcite nanograins form according to decarbonation and backreaction of calcite, as discussed in detail in Chapter 3. Static recrystallisation and annealing of the nanostructure in Stage 3 reduced the grain size immediately below the slip surface producing the foam nanostructure. Continuous, static recrystallisation lets truncated grains grow over the previous angled slip plane. Reactivation in Stage 4 of the foam nanostructure allows only for a minor displacement along a new angled slip plane while we hypothesise that a major portion of the slip event will only glide on the a-c coated slip surface and may strain the underlying nanostructure only to a minor degree. We hypothesise that continuous annealing of the nanostructure results in a grain-boundary strengthening effect (Hansen, 2004), ultimately locking the fault plane, and ending the seismic cycle on that particular fault plane. This hypothesis would imply that the strength of the nanostructure inside the lithified fault core is higher than the surrounding fault damage zone and that it is, therefore, more favourable to create a new fault than to continue slip on a pre-existing fault plane. 


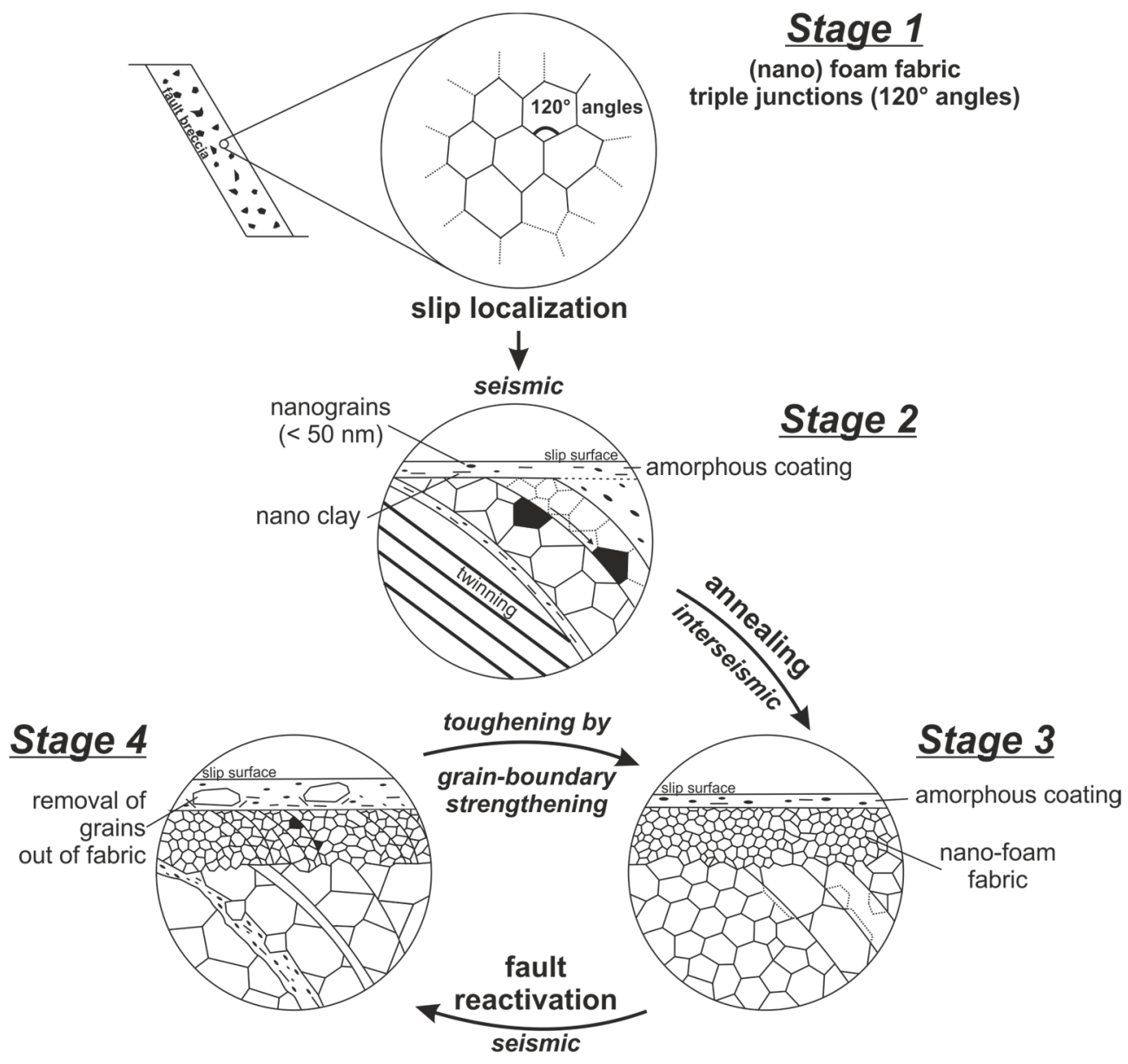

Figure 1: (previous page) Model of micro-, to nanostructure evolution by deformation localisation immediately at the principal slip surface. Stage 1: Equilibrium microstructure with 120a angles and triple junctions. Stage 2: Activation of the micro-, nanostructure. Possible twining in larger grains. Stage 3: Annealing of the strained region below the slip surface resulting in strain-induced grain boundary migration and reduction of grain size. Stage 4: Reactivation of foam nanostructure with only minor straining of adjacent nanostructure. The cycle ends as soon as the grain size is small enough that the bulk nanostructure becomes stronger than the surrounding fault rock. 

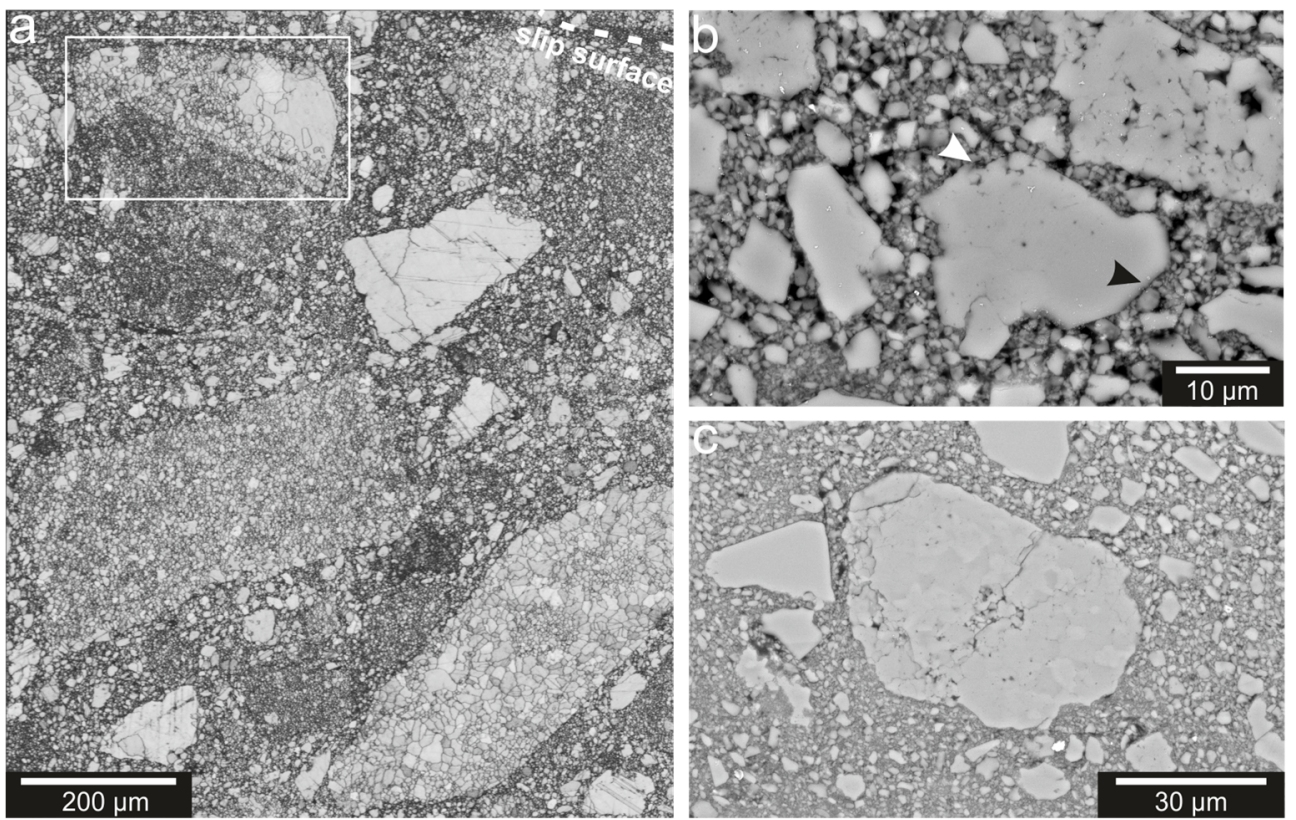

Figure 2: Comparison of annealing and static recrystallisation structures. a: Band-contrast EBSD map from Chapter 2. Host-rock clasts in the lower portion of the image show internal recrystallisation structures. Grain in white rectangle shows a transition state from calcite single crystal to polycrystalline clast. $\underline{\boldsymbol{b}}$ : Backscattered-electron image form experiment LHV985 $\left(v=1 \mathrm{~m} / \mathrm{s}, \sigma_{n}=2 \mathrm{MPa}, d=2 \mathrm{~m}, \mathrm{H}_{2}{ }^{18} \mathrm{O}\right)$. Calcite clasts show beginning modification of internal structure. White arrow indicates polycrystalline area while the black arrow indicates an unmodified grain area. $\underline{\text { : }}$ Backscattered-electron image form experiment LHV984 $\left(v=1 \mathrm{~m} / \mathrm{s}, \sigma_{n}=4 \mathrm{MPa}, d=20 \mathrm{~m}, \mathrm{H}_{2}{ }^{18} \mathrm{O}\right)$. Survivor clast with internal triple junction grain-boundary structure. Clast to the left shows no internal recrystallisation.

Another important result of this thesis is the evidence of crystal plasticity and the potential influence of fluids on active slip systems. The activation of the $(0001)<\overline{1} 2 \overline{1} 0>$ calcite-slip system in nature and experiments at lower temperatures then previous literature suggested demonstrates that more research is needed to better constrain the impact of fluids on dislocation creep in quartz and calcite. Where previous studies (e.g., Sammis et al., 1987; Blenkinsop, 1991) suggested granular flow with rather chaotic grain paths and rotations during cataclasis, the crystallographic preferred orientation from Chapter 3 resulting from only one deformation event suggests that crystal plasticity may play an important role already during cataclasis, possibly during fault-slip deceleration. With the emission of dislocations into the crystals, post-seismic annealing is effective at altering the grain morphology and reducing the grain size. The proposed process of cold-rolling and annealing in Chapter 2 is an elegant and widespread engineering method to strengthen metals and alloys by increasing the amount of grain boundaries (Hansen, 2004). Similar observations were also previously proposed for olivine (Druiventak et al., 2012; 
Matysiak and Trepmann, 2012) and quartz (Trepmann and Stöckhert, 2013; Trepmann et al., 2017). Thus, it is likely that such a process also occurs for calcite.

The additional role of amorphous carbon as reaction medium to form new calcite grains should not be overlooked. The consistent small grain size of $<50 \mathrm{~nm}$ for new calcite grains in lab and nature may provide an indicator on how long the amorphous carbon mixture stays viscous because crystal growth after nucleation is governed by diffusive mass transfer of the building blocks. As soon as amorphous carbon solidifies it will reduce or terminate element diffusion to the new crystal preventing further growth (Sunagawa, 2007). Termination of diffusion pathways inside the fault gouge would, therefore, influence fault healing on the short term. However, electron microscopy of calcite single crystals growing between cleavage trenches (Fig. 3) suggests that calcite growth and hence, fault plane healing proceeds over longer periods of time after a slip event. The key factor here is the growth morphology of the single crystals which are typical for slow growth and development under equilibrium conditions (Sunagawa, 2007).
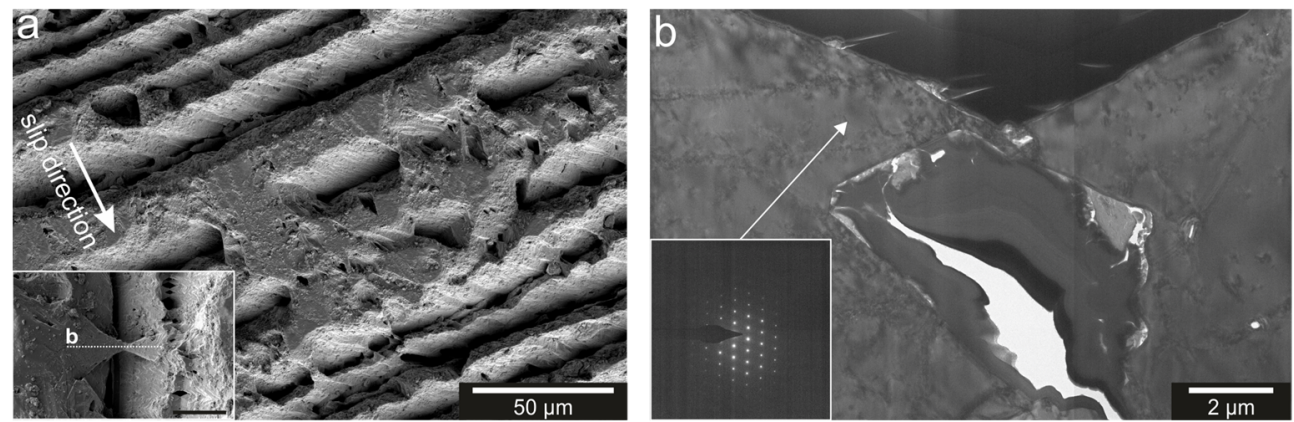

Figure 3: Evidence for slow fault healing processes from the Arkitsa fault exposure. a: Growth of pointy calcite crystals between cleavage fractures. Fault plane was reactivated after calcite growth explaining the flat top in line with cleavage trenches. Inset: Two calcite crystals intergrowing at the crystal tips. Dashed line indicates TEM cross section in b: b: TEM cross section of two calcite crystals. Inset shows electron diffraction pattern indicating that each crystal grows as single crystal.

\section{Suggestions for future work}

Paleoseismicity indicators are important structures, especially when the earthquake catalogue of a region prone to earthquakes is not complete. Fault mirror surfaces in carbonate rocks have been proposed as paleoseismicity markers as a counterpart to pseudotachylytes. However, since fault mirror surfaces can be produced in the laboratory also under subseismic velocities, fault mirrors cannot be used as unequivocal paleoseismicity markers. From the results across all chapters about carbonate deformation, it becomes clear that amorphous carbon is an 
important product of carbonate deformation (e.g., Chapter 1). As discussed in Chapter 3, there will likely be no dry fault zone in the Earth's crust and in such a case amorphous carbon could potentially be used to capture coseismic deformation temperatures. Comparison of the amorphous carbon electron energy loss spectra between the Greek faults in Chapter 1 and the electron energy loss spectra of the amorphous carbon produced during high-velocity sliding in Chapter 3 clearly shows a difference of the $\sigma^{*}$ region indicating a higher degree of the $\mathrm{sp}^{2}$-hybridised bond structure in the natural amorphous carbon (see Fig. 4). The study from Zhang et al. (2011) on heat-treating amorphous carbon shows that with rising temperature, the $\sigma^{*}$-region of the a-c spectra clearly gains ordering. The spectra change from one broad $\sigma^{*}$ peak to a flatter $\sigma^{*}$ region. In such a way, a study calibrating $\mathrm{sp}^{2}$ hybridisation of amorphous carbon by annealing the material at defined temperature steps would provide a powerful tool to quantify and use amorphous carbon as paleothermometer and hence, as paleoseismicity indicator in carbonate faults. Because electron energy loss spectroscopy is not a widespread technique and requires skilful instrument operation, calibration of the a-c hybridisation with temperature should be combined with complementary Raman spectroscopic measurements of evolution of the D and G bands. Similar Raman spectroscopy geothermometers have already been proposed by Beyssac et al. (2002) and Lünsdorf et al. (2017) but are calibrated with organic carbonaceous materials which may have different properties then carbonaceous materials from calcite decarbonation, which should be tested. In addition, there is no EELS data for the geothermometers proposed by Beyssac et al. (2002) and Lünsdorf et al. (2017). Application of the Raman spectroscopic carbon geothermometer of Lünsdorf et al. (2017) on the amorphous carbon of the two Greek faults studied here by a preliminary study (De Hoo, 2020) yielded broad scattering of temperatures, and suggests that a refinement of the geothermometer for carbonate fault materials would be beneficial.

As an alternative to a-c thermometry, quantifying the degree of crystalplastic deformation resulting from cataclastic carbonate deformation would provide another tool of microstructural paleoseismicity analysis. For this purpose, designing and executing a set of friction experiments at different sliding velocities, in particular low velocities, and subsequent slip system analysis with focus on subgrain misorientations (MIPF) could provide better constraints on the precise conditions under which the measured $(0001)<\overline{1} 2 \overline{1} 0>$ crystal orientation forms. Combing such 
experiments with the addition of pore fluid could provide additional insight into the influence of fluids on crystal plasticity in calcite.
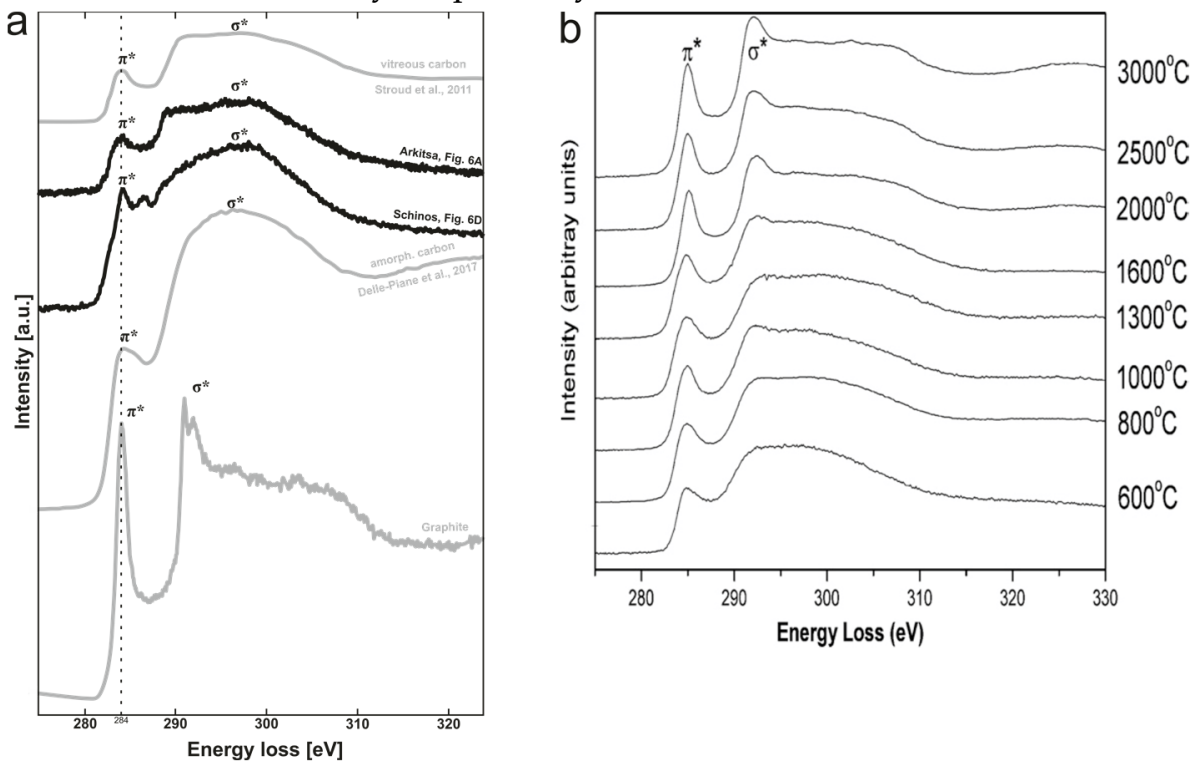

Figure 4: Electron energy loss spectra of amorphous carbon from this work (a:) and (Zhang, et al. 2011) (b:). a: Comparison of amorphous carbon from Chapter 1 with other carbon species. $\underline{b}$ : Evolution of EEL spectra of amorphous carbon from phenolic resin as a function of high-temperature treatment after (Zhang, et al. 2011). Spectra show a modification of the $\sigma^{*}$ region towards higher temperatures by regaining features inside the higher energy loss region, towards a $\sigma^{*}$ shape like graphite (see a:).

Following up on our hypothesis of in-situ electrolysis by triboelectric charging in microgranular aggregates, a deformation study investigating the buildup of an electric potential at higher strain rates would provide a better understanding of the driving forces behind chemical reactions in fault gouges. Based on our suggestion of triboelectric charging in calcite to split water, it is highly likely that such electric potentials are also present along the Dixie Valley fault. Frictional sliding with piezoelectric minerals, namely quartz, would provide a second source of electric potential adding to the potential from triboelectric charging. Such high potentials have been neglected but would provide a rather uncharted territory for future earthquake research. In particular, when frictional electrification may drive chemical reactions which appear to considerably influence fault friction (see Chapter 3). 


\section{References}

Beyssac, O., Goffé, B., Chopin, C., Rouzaud, J. N., 2002. Raman spectra of carbonaceous material in metasediments: a new geothermometer. Journal of Metamorphic Geology. 20, 859-871.

Blenkinsop, T. G., 1991. Cataclasis and processes of particle size reduction. Pure and Applied Geophysics. 136, 59-86.

Brace, W. F. and Byerlee, J. D., 1966. Stick-slip as a mechanism for earthquakes. Science. 153, 990-992.

Druiventak, A., Matysiak, A., Renner, J., Trepmann, C. A., 2012. Kick-and-cook experiments on peridotite: simulating coseismic deformation and post-seismic creep. Terra Nova. 24, 62-69.

Hansen, N., 2004. Hall-Petch relation and boundary strengthening. Scripta Materialia. 51, 801-806.

de Hoo, W., 2020. The application of a calibrated Raman spectroscopy geothermometer on temperature constraints of carbonaceous material-bearing rocks. M.Sc. Thesis. Department of Earthsciences, Utrecht University.

Lünsdorf, N. K., Dunkl, I., Schmidt, B. C., Rantitsch, G., von Eynatten, H., 2017. Towards a higher comparability of geothermometric data obtained by Raman spectroscopy of carbonaceous material. Part 2: a revised geothermometer. Geostandards and Geoanalytical Research. 41, 593-612.

Matysiak, A. K. and Trepmann, C. A., 2012. Crystal-plastic deformation and recrystallization of peridotite controlled by the seismic cycle. Tectonophysics. 530, 111-127.

Oohashi, K., Hirose, T., Shimamoto, T., 2011. Shear-induced graphitization of carbonaceous materials during seismic fault motion: Experiments and possible implications for fault mechanics. Journal of Structural Geology. 33, 1122-1134.

Sammis, C., King, G., Biegel, R., 1987. The kinematics of gouge deformation. Pure and Applied Geophysics. 125, 777-812.

Siman-Tov, S., Aharonov, E., Sagy, A., Emmanuel, S., 2013. Nanograins form carbonate fault mirrors. Geology. 41, 703-706.

Sunagawa, I., 2007. Crystals: Growth, Morphology, \& Perfection. Cambridge University Press. 
Trepmann, C. A. and Stöckhert, B., 2013. Short-wavelength undulatory extinction in quartz recording coseismic deformation in the middle crust-an experimental study. Solid Earth. 4, 263.

Trepmann, C. A., Hsu, C., Hentschel, F., Döhler, K., Schneider, C., Wichmann, V., 2017. Recrystallization of quartz after low-temperature plasticity-The record of stress relaxation below the seismogenic zone. Journal of Structural Geology. 95, 77-92.

Zhang, Z., Brydson, R., Aslam, Z., Reddy, S., Brown, A., Westwood, A., Rand, B., 2011. Investigating the structure of non-graphitising carbons using electron energy loss spectroscopy in the transmission electron microscope. Carbon. 49, 5049-5063. 


\section{Appendix}

Raman spectra of materials used during deformation experiments in Chapter 3

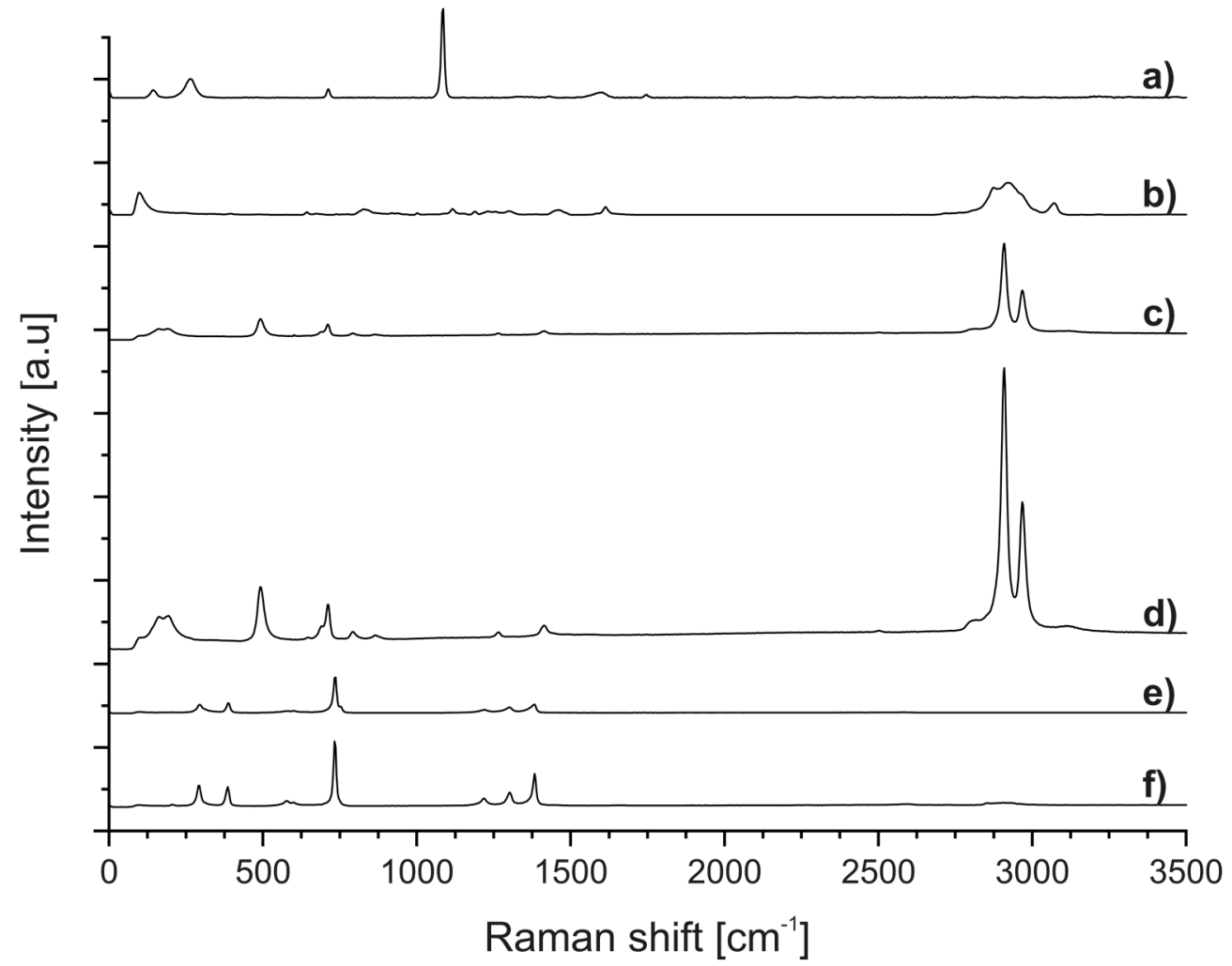

Figure 1: Raman spectra of all materials used during low-, high-velocity deformation experiments. a) Calcite starting material with grain size $28 \mu \mathrm{m}$. b) Araldite2020 (epoxy). c) Rubber plug of low-velocity experiments. d) Silicone oil used as confining medium for low-velocity experiments. e) Thermosensitive silicone sleeve. f) Teflon foil. 


\title{
Data publication to Chapter 1: Nanoscale structures and properties of carbonate fault mirrors revealed by scanning electron and scanning transmission electron microscope images, electron energy loss and Raman spectra
}

Ohl, Markus; Plümper, Oliver; Chatzaras, Vasileios; Wallis, David; Vollmer, Christian; Drury, Martyn (2020): Nanoscale structures and properties of carbonate fault mirrors revealed by scanning electron and scanning transmission electron microscope images, electron energy loss and Raman spectra. GFZ Data Services. https://doi.org/10.5880/fidgeo.2020.007

\begin{abstract}
This data publication contains scanning electron microscope (SEM) and (scanning) transmission electron microscope ((S)TEM) images as well as electron energy loss spectra (EELS) and Raman spectra of the principal slip surface of carbonate fault mirrors. We analysed a total of eleven samples to investigate the formation mechanisms of fault mirrors in carbonates. The samples were taken as drill cores in Central Greece from two different outcrop locations. The first location, close to Arkitsa, is a large anthropogenic outcrop exposing three large fault planes. The second location is close to Schinos and was also formed by human interaction at the side of a gravel road. The data set contains supplemental material to the publication "Mechanisms of fault mirror formation and fault healing in carbonate rocks" by Ohl et al., (2020). In addition to the electron microscopy images we provide the spectra files of the Raman and EELS measurements for the identification of the carbon species in relation to the principal slip surface. The publication concludes that decarbonation of calcite during fault slip and the subsequent reaction of the decarbonation products produces fault mirror surfaces. Post-seismic hybridization of carbon results in partly-hybridised amorphous carbon and contributes to connecting hanging wall and footwall. In addition, post-seismic carbonation of portlandite produces secondary nano-sized calcite crystals $<50 \mathrm{~nm}$ facilitating fault healing.
\end{abstract}

\section{Methods}

The SEM images were acquired on a FEI Helios Nanolab G3 DualBeam focused ion beam scanning electron microscope (FIB-SEM). For the preparation of TEM foils, prior to ion-beam deposition of platinum, a 200-nm layer of platinum was 
Data publication to Chapter 1: Nanoscale structures and properties of carbonate fault mirrors revealed by scanning electron and scanning transmission electron microscope images, electron energy loss and Raman spectra

deposited by electron-beam precipitation. TEM imaging was carried out with a FEI Talos F200X at $200 \mathrm{kV}$ acceleration voltage and 5-10 nA beam current. Electron imaging was done at the Utrecht University electron microscope center, The Netherlands. EELS data was acquired using a Zeiss Libra 200FE at 200kV with an in-column Omega energy filter at the Westfälische Wilhelms-Universität (WWU) in Münster. The energy resolution of the EELS analyses was $0.7 \mathrm{eV}$, measured at the full width at half maximum (FWHM) of the zero-loss peak. Energy loss spectra were obtained at 250,000x magnification with a $100 \mu \mathrm{m}$ filter-entrance aperture giving an effective aperture of about $40 \mathrm{~nm}$ on the sample. Raman spectroscopy was carried out using a WiTec ALPHA300R confocal microscope and a $532 \mathrm{~nm}$ wavelength laser and a spectrometer grating of 600 grooves $/ \mathrm{cm}$.

\section{Files}

This data publication consists of SEM and (S)TEM images organized in folders named Figure $X$, where $X$ is the number of the supplemental figure referred to in Ohl et al. (2020). The contents of these folders are described in the 2020-007_Ohl2020-List_of_files.xls. In addition, the untreated Raman spectroscopy and electron energy loss spectroscopy spectra are provided as tab-separated files containing the $\mathrm{XY}$ coordinates for Arkitsa and Schinos. For the Raman spectroscopy measurements, the first column is the wavenumber shift in $\left[\mathrm{rel} . \mathrm{cm}^{-1}\right]$ and the second column refers to counts per second [cts/s] acquired on the spectrometer. In case of the EELS measurements, the first column is the electron energy loss in $[\mathrm{eV}]$ and the second column represents the intensity in counts per second [cts/s] on the CCD camera. 


\section{Data publication to Chapter 2: Multi-scale electron crystal- orientation diffraction of seismically active carbonate fault rocks}

https://public.yoda.uu.nl/geo/UU01/A77O7X.html

We determine the active deformation mechanisms in two active carbonate fault zones in Greece. Detailed slip-system analyses in combination with highresolution nanostructural investigations show a throughout contribution of crystal plasticity, evident from subgrain-wall misorientations. Post-deformational static recrystallisation and annealing reduces the grain size and offers an alternative mechanism of nanograin formation. The decrease in grain size results in a grainboundary strengthening effect and slip localisation which can be observed over several orders of length scales. The data publication contains photographs, electronbackscatter diffraction (EBSD) data, transmission electron microscope (TEM) images and automated crystal-orientation mapping (ACOM)-TEM data organised in seven subfolder named Figure $x$, where $x$ is the number of the figure referring to the full publication. The grain-size distributions obtained from the crystal-orientation mapping techniques are provided as tab-separated files. We provide the raw and binned grain-size distributions together with the calculated, relative frequency for the fractal dimension plot. We also provide one EBSD map of the Arkitsa fault exposure as *.cpr and *.crc file. MATLAB MTEX scripts for obtaining the EBSD map plots, pole figures and the raw grain-size distribution are provided. Thin sections were prepared from drill cores that were cut parallel to the slip direction and normal to the slip surface. Thin sections were polished with $1 \mu \mathrm{m}$ and $0.3 \mu \mathrm{m}$ diamond suspensions and finished with $0.025 \mu \mathrm{m}$ colloidal silica. To reduce charging during EBSD data acquisition, the thin sections were carbon coated. EBSD maps were acquired with a Philips XL30 field emission scanning electron microscope equipped with an Oxford instruments Nordlys 2 CCD camera and Aztec software at $30 \mathrm{kV}$ accelerating voltage, $9.5 \mathrm{nA}$ probe current, and step size of $0.5 \mu \mathrm{m}$ for the Arkitsa sample and $20 \mathrm{kV}$ accelerating voltage, $9.5 \mathrm{nA}$ probe current, $0.7 \mu \mathrm{m}$ step size for the Schinos sample. Nanoscale imaging was carried out with a FEI Talos F200X at 200 $\mathrm{kV}$ acceleration voltage and 5-10 nA beam current. ACOM-TEM data were acquired on electron-transparent foils prepared with a FEI Helios G3 Nanolab UC focussed ion-beam scanning electron microscope (FIB-SEM). Nanoscale map acquisition was executed with a dedicated NanoMEGAS ASTAR/SPINSTAR system on a FEI Tecnai 
Data publication to Chapter 2: Multi-scale electron crystal-orientation diffraction of seismically active carbonate fault rocks

G2-20 twin at the Unité Matériaux et Transformation in Lille, France. Beam conditions during ACOM for the nanoscale map acquisition were $200 \mathrm{kV}$ accelerating voltage and spot size 11, giving a 1-nm probe diameter, which results in a minimum step size of $2 \mathrm{~nm}$. contact: m.ohl@uu.nl 


\section{Acknowledgements/Dankwoord}

First of all, I would like to thank my Promoter and Co-promoters, Martyn Drury, Oliver Plümper, and André Niemeijer. Each of you helped me to accomplish this piece of scientific work in your own way. Oliver, as my daily supervisor, you were the one with the most intense contact, in one way or another. From you, I learned everything about FIB work and TEM, which lay the basis for most of the analytical work in this thesis. Your rigorous and consequent work attitude pushed my boundaries more than once and gave me enough grit to work through four years of PhD. Looking back, I seriously enjoyed our heated discussions that left me sometimes speechless but eager to improve myself. A huge "thank you" for our great time during fieldwork, e.g., in the United States of America or in Norway. Martyn, I am profoundly grateful for all your help and input you provided over the course of my PhD. You constantly believed in me, and I don't know if you are aware of it but it helped me a great deal through my PhD. I enjoyed all our discussions, especially about EBSD and metamorphic rocks. On top, I enjoyed all the fieldwork, e.g., in Greece, or field teaching in the Pyrenees with you. André, I am deeply grateful for all your help regarding laboratory work. Our fruitful discussions often sparked new ideas to go forward and helped improve this work at any stage. I also highly enjoyed teaching students in the field together with you. I would like to thank the Dutch research organisation (NWO) who provided the funding for this project.

I would like to thank all my co-authors who contributed to the individual chapters with their scientific input. Apart from my supervisors, I would like to thank additionally for Chapter 1: Vasileios Chatzaras, David Wallis, and Christian Vollmer. For Chapter 2: Billy Nzogang, Alexandre Mussi, David Wallis, and Patrick Cordier. For Chapter 3: Jianye Chen, André Niemeijer, Lubos Polerecky, Michiel Kienhuis, Jean-Nicolas Audinot, Tom Wirtz, and Helen E. King. For Chapter 4, my additional thanks go to Renate Reschetizka. I would also like to thank Chris Schnijdenberg and Hans Meeldijk from the EM square, for their invaluable help with electron microscopy.

Not to forget all the people I met along my PhD journey. Claudia-Corinna Giese, thank you very much for being such a great friend, listening to me complaining, or just reminiscing about the world! Most of the people I met gather under the "usual suspects". Unfortunately, at the time of finishing my journey most of you are not around UU anymore but I will try to name a few: Evangelos Korkolis, 
Ronald Pijnenburg, Nienke Blom, Nina Kopacz, Floris Teuling, Maartje Hamers, Martijn van den Ende, Tom Hoyle, Mariska Schimmel, Luuk Hunfeld, Maartje Houben, Suzanne Atkins, Elisabeth Jorissen, Anouk Beniest, Maria Koroni, Simon Schneider, Antoine Auzemery, Sujania Talavera-Soza, Pete McPhee, Dan Palcu, Karin Sant, Eldert Advokaat, Nevena Andric, Sahar Ash, Chris van Baak, Caspar Sinn. Please forgive me when you are not among the list, you are not forgotten!

Not to forget Alexander Krüger, Stefan Custers and Vincent Bergsma. Thanks for being invaluable friends outside of university because sometimes it's also important to not talk about work.

My additional thanks go to Hester van Bork and her family. Hester, you supported me wherever you could along my journey and listened to me complaining about my study. You took me in into your family and welcomed me in such a warm way that it made me feel as being part of your family. For that, I would also like to thank Frans van Bork and Bets Peerdeman.

Thanks to all my friends and colleagues during my undergraduate studies in Bochum. Sebastian Freye, Felix Besenschek, Almuth Hönscheid, Fabian Schocke, Mathis Daedelow and, Santana-Maria Fuchs, to just name a few of the most influential persons.

My biggest thanks go to my family - thank you for all your love and support! To my mother, Elona Ohl-Busch, and my father Siegmund Ohl, that you have been there for me every time I needed you, and that you were there for me even when I didn't know I needed you. Vielen Dank euch beiden, ohne euch hätte ich es niemals so weit in meinem Leben geschafft! 


\section{About the author}

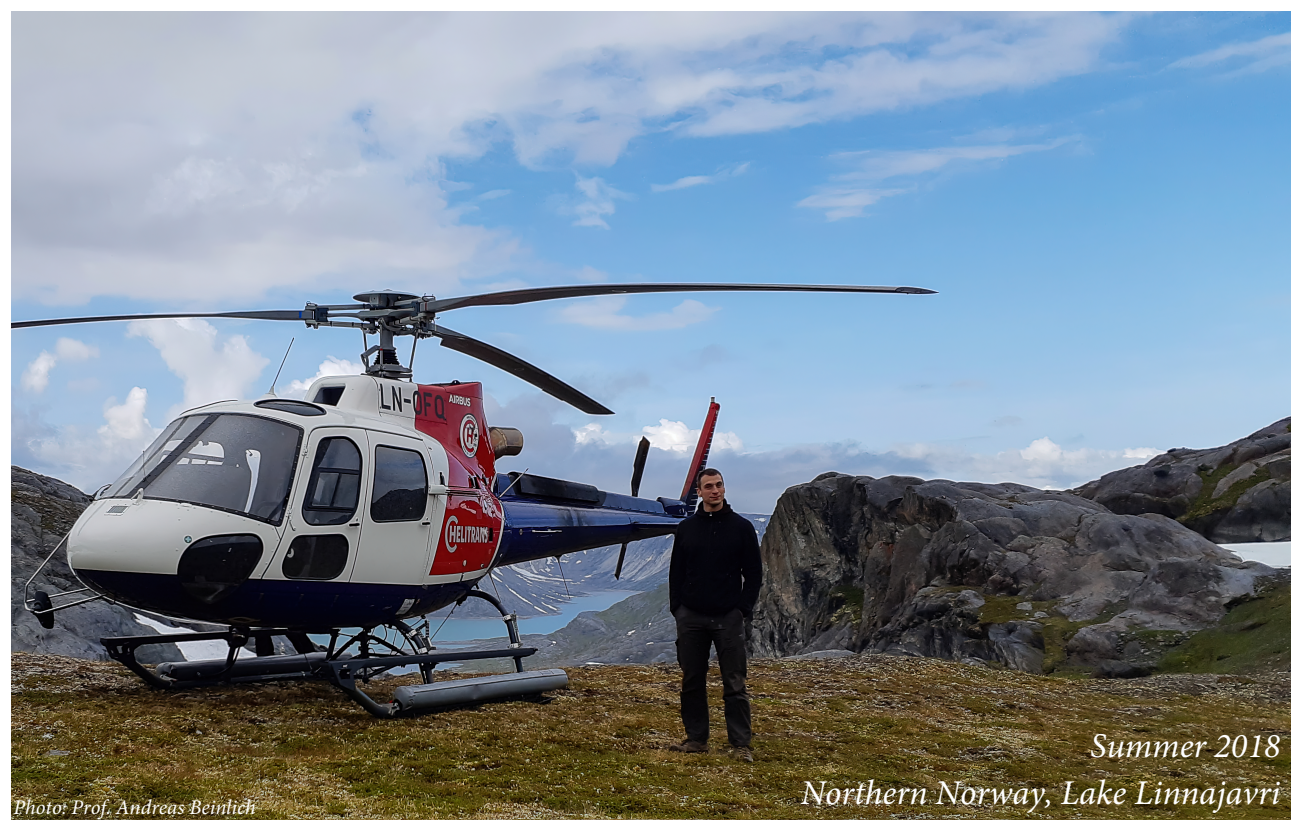

Markus Ohl was born on Sunday, the $5^{\text {th }}$ of April 1987 in Recklinghausen, Germany. As the son of Elona Ohl (now Ohl-Busch) and Siegmund Ohl, he discovered already at an early age of 6 the joy of collecting rocks; very much contributing to the wear of his parents' coat pockets. Markus began his professional career in 2008, studying Geosciences in Bochum, Germany, and finished with a Masters' degree in Geoscience in 2014. In June 2016, after a one-year detour working for a civil engineering company in Bonn, Germany, Markus began his PhD study at Utrecht University, The Netherlands. The PhD project under the supervision of Martyn Drury, Oliver Plümper and André Niemeijer offered the opportunity to work on his beloved microstructures again. He finished his PhD degree in February 2021, in the middle of the $3^{\text {rd }}$ COVID-19 lockdown. Markus will continue his academic career with a Post-doc position at Utrecht University in X-Ray microscope tomography and electron microscopy. 


\section{List of scientific contributions}

\section{Peer-reviewed publications}

Ohl, M., Nzogang, B., Mussi, A., Wallis, D., Drury, M. \& Plümper, O. 2020. Crystalplastic deformation in seismically active carbonate fault rocks. Journal of Geophysical Research: Solid Earth. doi: 10.1029/2020JB020626.

Ohl, M., Plümper, O., Chatzaras, V., Wallis, D., Vollmer, C., Drury, M.R., 2020. Mechanisms of fault mirror formation and fault healing in carbonate rocks. Earth and Planetary Science Letters 530, doi.org/10.1016/j.epsl.2019.115886.

Wallis, D., Hansen, L., Kumamoto, K., Thom, C., Plümper, O., Ohl, M., Durham, W., Goldsby, D., Armstrong, D., Meyers, C., Goddard, R., Warren, J., Breithaupt, T., Drury, M.R., Wilkinson, A., 2019. Dislocation interactions during lowtemperature plasticity of olivine strengthen the lithospheric mantle, doi.org/10.1016/j.epsl.2020.116349.

\section{Peer-reviewed publications in preparation}

Ohl, M., Chen, J., Niemeijer, A., King, H.E., Polerecky, L., Audinot, J.N., Wirtz, T., Plümper, O. Fluid-induced phase transformations explain weakening in crustal carbonate faults.

Ohl, M., Reschetizka, R., Plümper, O. Formation mechanisms of silicate fault mirrors and implications for seismic deformation in the absence of melting.

\section{Conference contributions}

Ohl et al., (2020): Deciphering deformation mechanisms during seismic slip along wet carbonate faults (Conference abstract, EGU 2020).

Ohl et al., (2020): Silicate fault mirrors and implications for crustal fault rheology in the absence of melting (Conference abstract, Dutch Earth science conference (NAC GEO) 2019).

Ohl et al., (2019): Nanoscale dissolution processes and colloid-suspension formation as possible weakening mechanism of seismogenic crustal carbonate fault (Conference abstract, (GeoProc 2019). 
Ohl et al., (2019): Nanomechanics in crustal fault zones: Mechanical amorphisation and colloid-suspension formation weakens crustal faults (Conference abstract, Dutch Earth science conference (NAC GEO) 2019).

Ohl et al., (2018): Co-seismic nanoscale fault gouge deformation mechanisms revealed by automated crystal orientation mapping transmission electron microscopy (ACOM-TEM) (Gordon research conference (GRC) 2018).

Ohl et al., (2018): In-situ stable isotope tracing of nanoscale deformation processes in earthquake-prone crustal fault materials (Conference abstract, Goldschmidt 2018).

Ohl et al., (2018): Deformation mechanisms and slip localization in seismically active carbonate faults: A case study on natural carbonate fault gouges from one of the most seismically active regions in Europe (Conference abstract, Dutch Earth science conference (NAC GEO) 2018).

Ohl et al., (2017): Multi-scale investigation into the mechanisms of fault mirror formation in seismically active carbonate rocks (Conference abstract, EGU 2017). 